\title{
An Inventory of Terrestrial Mammals at National Parks in the Northeast Temperate Network and Sagamore Hill National Historic Site
}

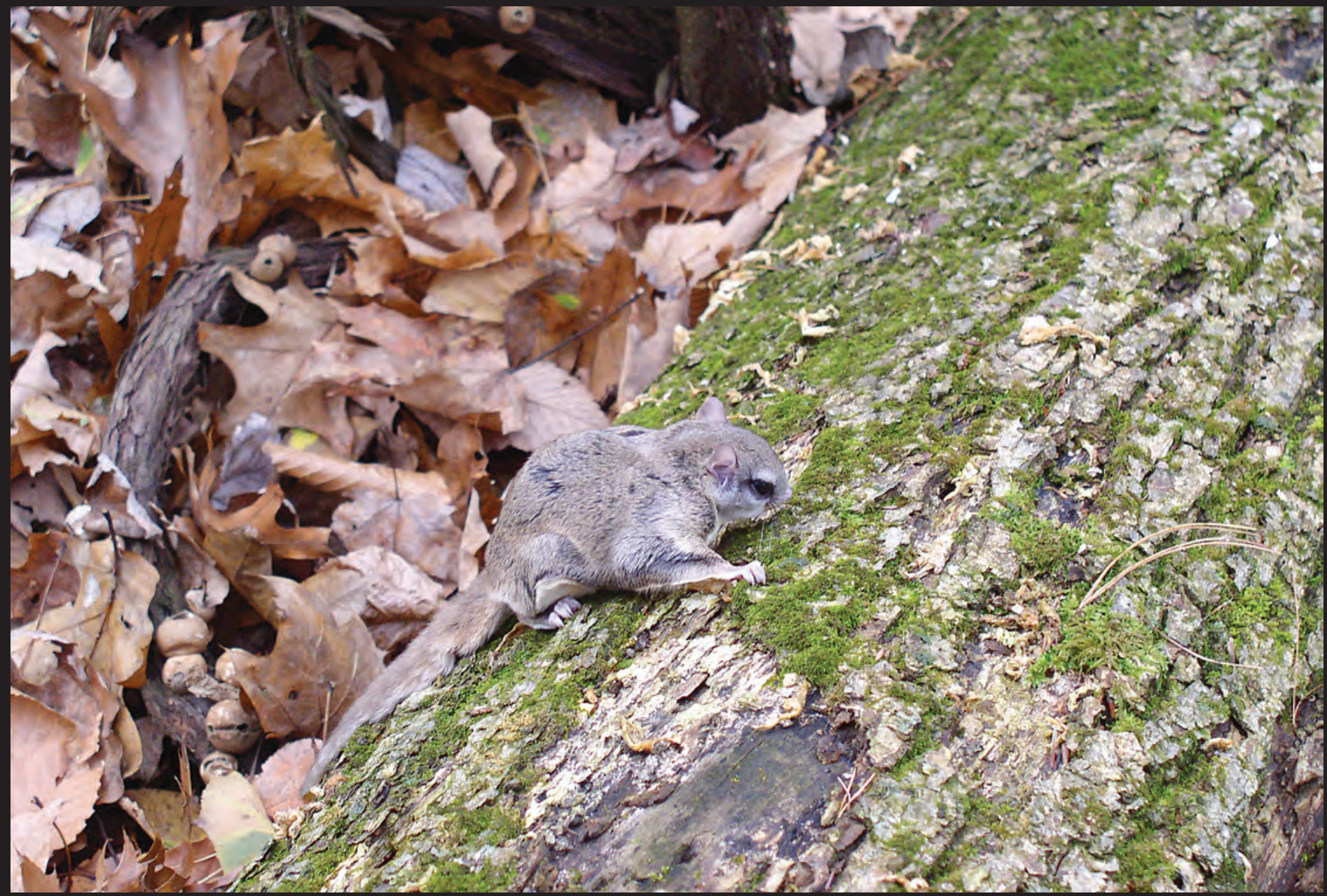

Scientific Investigations Report 2007-5245 
Cover. Southern Flying Squirrel (Glaucomys volans), released following capture at Saratoga National Historical Park, New York, November 2004. Photograph by Andrew Gilbert, U.S. Geological Survey. 


\section{An Inventory of Terrestrial Mammals at National Parks in the Northeast Temperate Network and Sagamore Hill National Historic Site}

By Andrew T. Gilbert, Allan F. O'Connell, Jr., Elizabeth M. Annand, Neil W. Talancy, John R. Sauer, and James D. Nichols

Prepared in cooperation with the National Park Service

Scientific Investigations Report 2007-5245 


\section{U.S. Department of the Interior DIRK KEMPTHORNE, Secretary}

\section{U.S. Geological Survey \\ Mark D. Myers, Director}

\section{U.S. Geological Survey, Reston, Virginia: 2008}

For product and ordering information:

World Wide Web: http://www.usgs.gov/pubprod

Telephone: 1-888-ASK-USGS

For more information on the USGS--the Federal source for science about the Earth, its natural and living resources, natural hazards, and the environment:

World Wide Web: http://www.usgs.gov

Telephone: 1-888-ASK-USGS

Any use of trade, product, or firm names is for descriptive purposes only and does not imply endorsement by the U.S. Government.

Although the ArcObjects programs in this report have been used by the USGS, no warranty, expressed or implied, is made by the USGS or the United States Government as to the accuracy and functioning of the programs and related program material nor shall the fact of distribution constitute any such warranty, and no responsibility is assumed by the USGS in connection therewith.

Although this report is in the public domain, permission must be secured from the individual copyright owners to reproduce any copyrighted materials contained within this report.

Suggested citation:

Gilbert, A.T., O'Connell, A.F., Jr., Annand, E.M., Talancy, N.W., Sauer, J.R., and Nichols, J.D., 2008, An inventory of terrestrial mammals at National Parks in the Northeast Temperate Network and Sagamore Hill National Historic Site: U.S. Geological Survey Scientific Investigations Report 2007-5247, 158 p. 


\section{Contents}

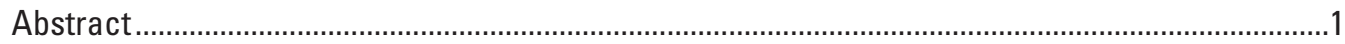

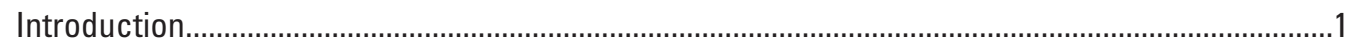

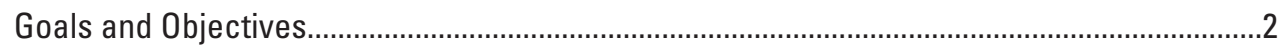

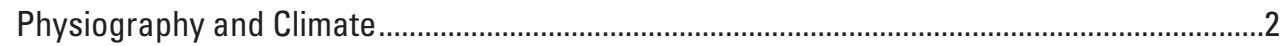

Historical Research, Surveys, and Inventories of Mammals ..................................................

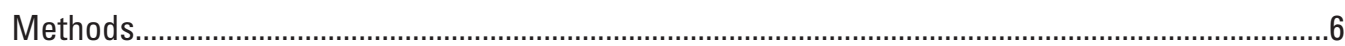

Approach to Inventory Design......................................................................................

Spatial Sampling Design and Sampling-Point Allocation ........................................................

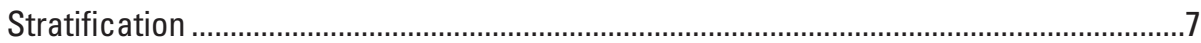

Systematic Sampling Scheme ........................................................................................

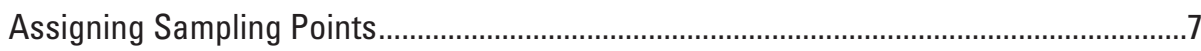

Locating Sampling Points ................................................................................................11

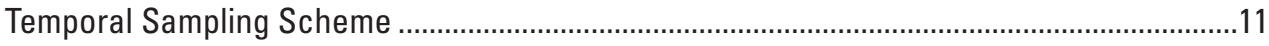

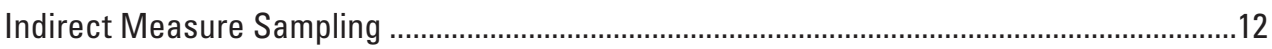

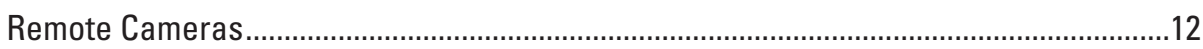

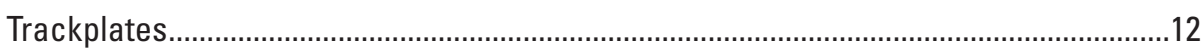

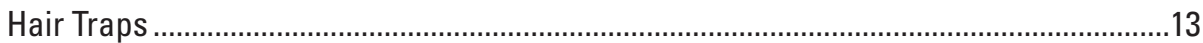

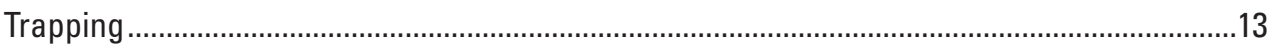

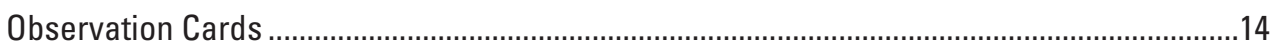

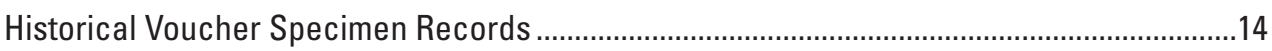

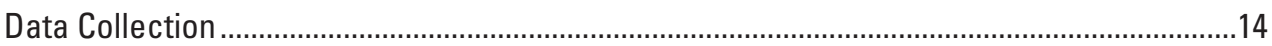

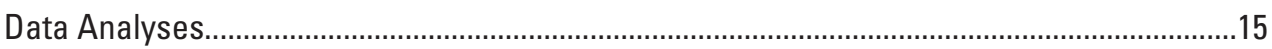

Weir Farm National Historic Site (WEFA) ………………...........................................................16

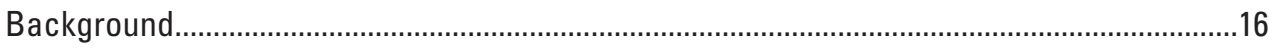

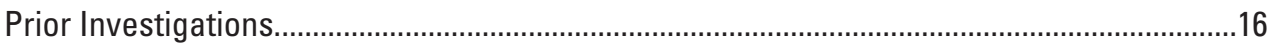

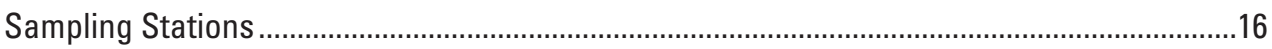

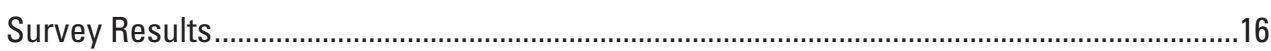

Species Expected but Not Detected ..............................................................................17

Endangered and Threatened Species...........................................................................22

Morristown National Historical Park (MORR) ...............................................................................23

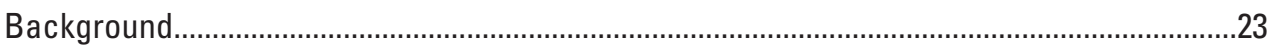

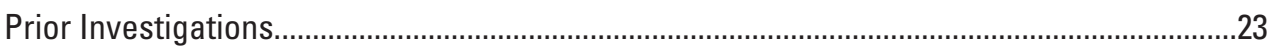

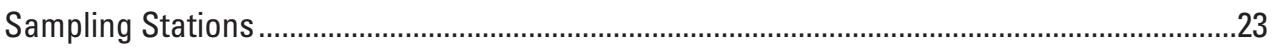

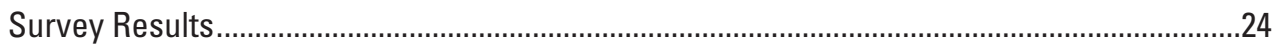

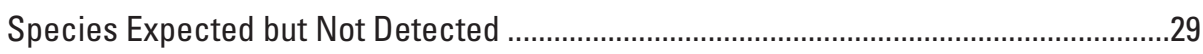

Endangered and Threatened Species............................................................................29

Roosevelt-Vanderbilt National Historic Sites (ROVA) ....................................................................

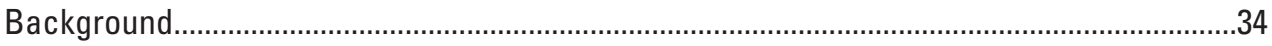

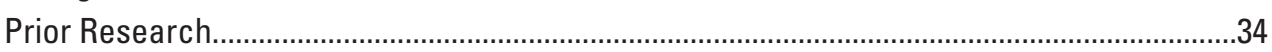

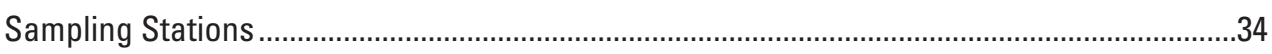

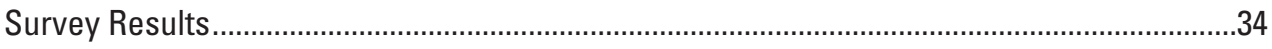

Species Expected but Not Detected …………………............................................. 
Endangered and Threatened Species..........................................................................41

Minute Man National Historical Park (MIMA) ............................................................................46

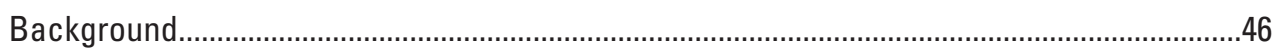

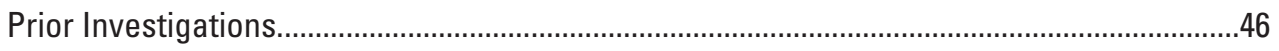

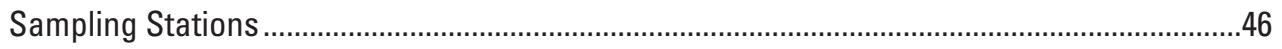

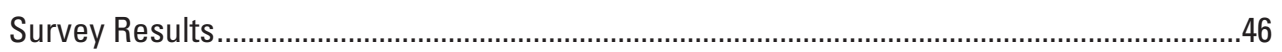

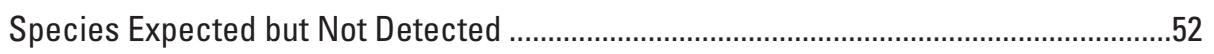

Endangered and Threatened Species..................................................................52

Saugus Iron Works National Historic Site (SAIR) ………...........................................................5

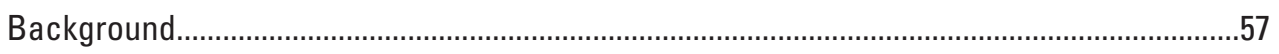

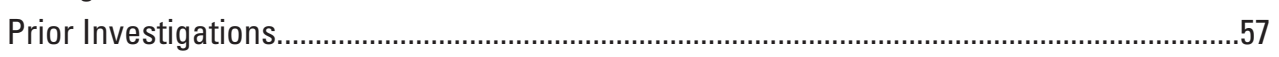

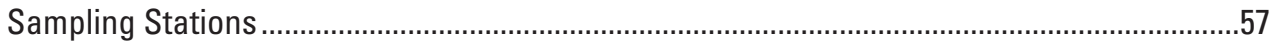

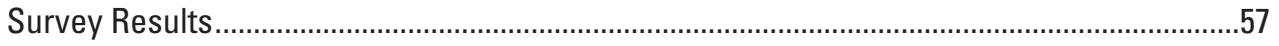

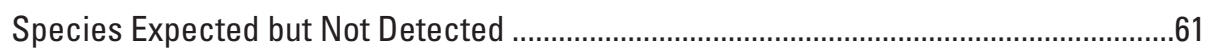

Endangered and Threatened Species............................................................................62

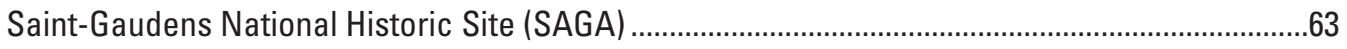

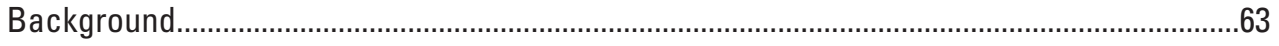

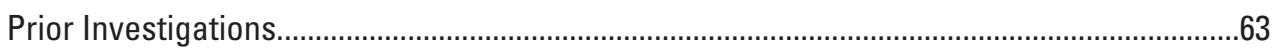

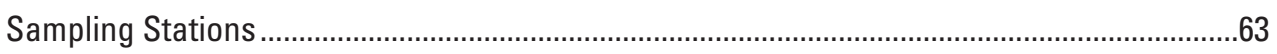

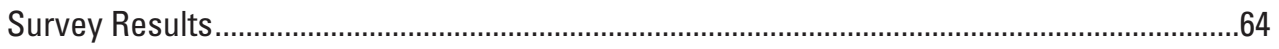

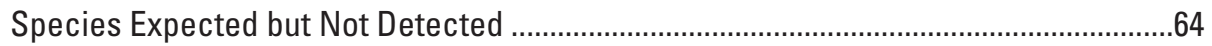

Endangered and Threatened Species.........................................................................68

Marsh-Billings-Rockefeller National Historical Park (MABI) ............................................................

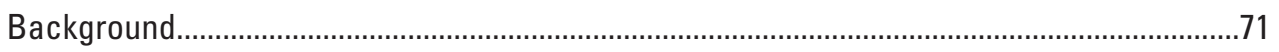

Prior Investigations......................................................................................................

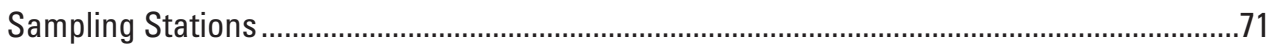

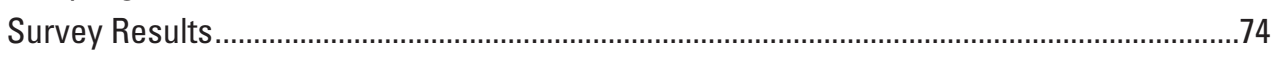

Species Expected but Not Detected ........................................................................74

Endangered and Threatened Species.........................................................................74

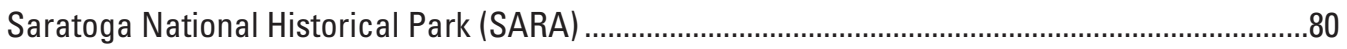

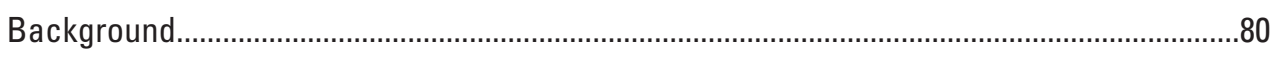

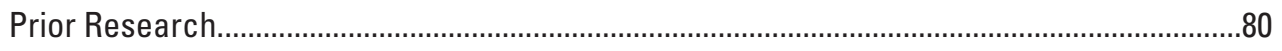

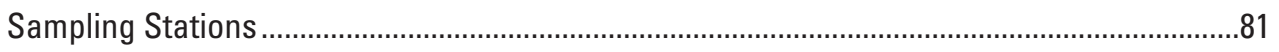

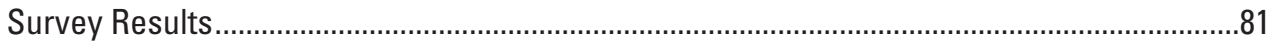

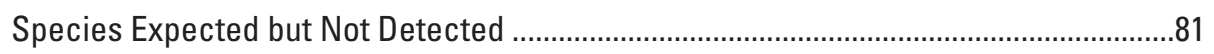

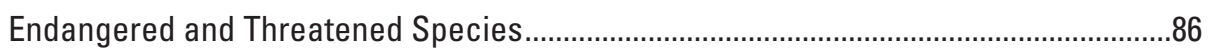

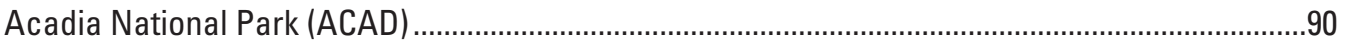

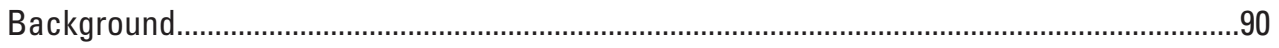

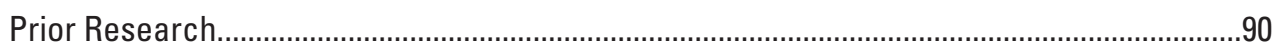

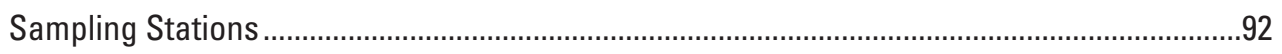

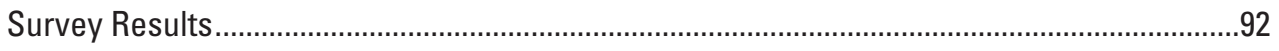

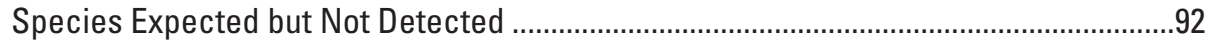

Endangered and Threatened Species.....................................................................96

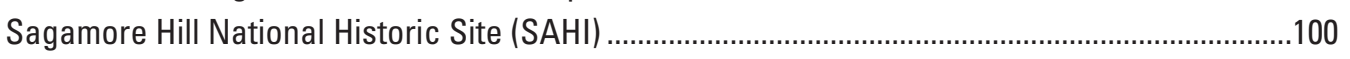

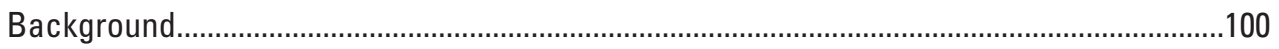




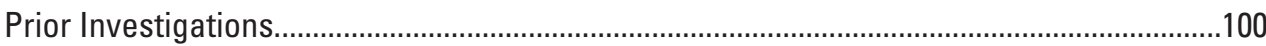

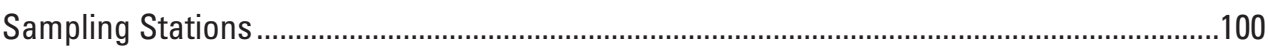

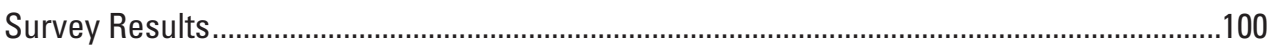

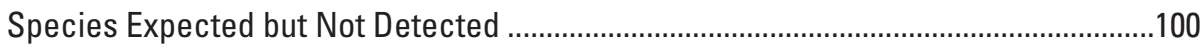

Endangered and Threatened Species.........................................................................101

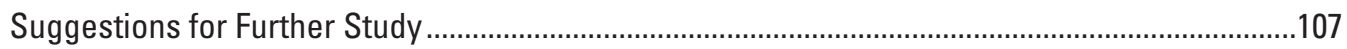

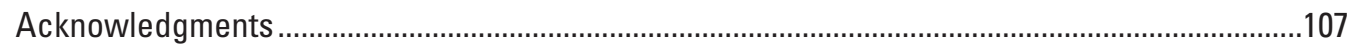

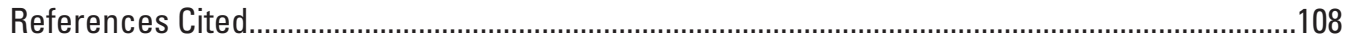

Appendix A. ArcObjects programming code for the macro developed to generate a sampling grid in ArcMap 8.1 .....................................................................................................116

Appendix B. ArcObjects programming code for the macro developed to draw randomized systematic samples by strata in ArcMap 8.1 ..............................................................125

Appendix C. Method employed for generating randomized systematic samples ......................133

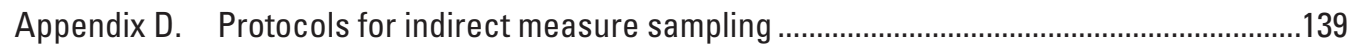

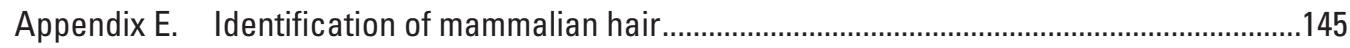

Appendix F. Observation card used in the Northeast Temperate Network mammal inventory ............................................................................................................ 147

Appendix G. Field data sheets distributed to park staff.......................................................148

Appendix H. Identified hairs collected during the Northeast Temperate Network and Sagamore Hill National Historic Site mammal inventory based on physical characteristics and matrix-assisted laser desorption/ionization time-of-flight mass spectrometry (MALDI-

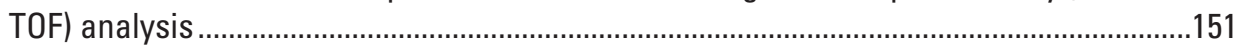




\section{Figures}

1. Map showing National Park units and representative ecoregions in the northeastern United States included in the 2004 mammal inventory of the Northeast Temperate Network and Sagamore Hill National Historic Site in the Northeast Coastal and Barrier Network.

2-5. Diagram showing-

2. Steps used to select sampling points for the 2004 mammal inventory using a grid system, vegetation strata, and random point placement

3. Steps used to calculate the sampling frame and assign sampling points for the 2004 mammal inventory.

4. Design of indirect measure stations used to detect mammals in the 2004 mammal inventory

5. Small mammal trap lines and placement of squirrel-sized and fox-sized live traps used in the 2004 mammal inventory of national parks in the Northeast Temperate Network and Sagamore Hill National Historic Site

6-35. Map showing-

6. Locations of remote cameras and other detection devices, trapping equipment, and orientation of small-mammal trap lines used in the 2004 mammal inventory at Weir Farm National Historic Site.

7. Species diversity results for trapping and indirect measure sampling stations during the 2004 mammal inventory at Weir Farm National Historic Site.

8. Locations of remote cameras and other detection devices, trapping equipment, and orientation of small-mammal trap lines used in the 2004 mammal inventory at Morristown National Historical Park-Jockey Hollow Unit.

9. Locations of remote cameras and other detection devices, trapping equipment, and orientation of small-mammal trap lines used in the 2004 mammal inventory at Morristown National Historical Park-New Jersey Brigade Unit.....

10. Species diversity at trapping and indirect measure stations during the 2004 mammal inventory at Morristown National Historical Park-Jockey Hollow Unit...31

11. Species diversity at trapping and indirect measure stations during the 2004 mammal inventory at Morristown National Historical Park-New Jersey Brigade Unit..

12. Locations of remote cameras and other detection devices, trapping equipment, and orientation of small-mammal trap lines used in the 2004 mammal inventory at Vanderbilt Mansion National Historic Site..

13. Locations of remote cameras and other detection devices, trapping equipment, and orientation of small-mammal trap lines used in the 2004 mammal inventory at Home of Franklin D. Roosevelt National Historic Site.

14. Locations of remote cameras and other detection devices, trapping equipment, and orientation of small-mammal trap lines used in the 2004 mammal inventory at Eleanor Roosevelt National Historic Site.

15. Species diversity at trapping and indirect measure sampling stations during the 2004 mammal inventory at Vanderbilt Mansion National Historic Site.

16. Species diversity at trapping and indirect measure sampling stations during the 2004 mammal inventory at Home of Franklin D. Roosevelt National Historic Site

17. Species diversity at trapping and indirect measure sampling stations during 
the 2004 mammal inventory at Eleanor Roosevelt National Historic Site

18. Locations of remote cameras and other detection devices, trapping equipment, and orientation of small-mammal trap lines used in the 2004 mammal inventory in the western part of Minute Man National Historical Park.

19. Locations of remote cameras and other detection devices, trapping equipment, and orientation of small-mammal trap lines used in the 2004 mammal inventory in the eastern part of Minute Man National Historical Park.

20. Species diversity at trapping and indirect measure sampling stations during the 2004 mammal inventory in the western part of Minute Man National Historical Park.

21. Species diversity at trapping and indirect measure sampling stations during the 2004 mammal inventory in the eastern part of Minute Man National Historical Park.

22. Locations of remote cameras and other detection devices, trapping equipment, and orientation of small-mammal trap lines used in the 2004 mammal inventory at Saugus Iron Works National Historic Site

23. Species diversity at trapping and indirect measure sampling stations during the 2004 mammal inventory at Saugus Iron Works National Historic Site

24. Locations of remote cameras and other detection devices, trapping equipment, and orientation of small-mammal trap lines used in the 2004 mammal inventory at Saint-Gaudens National Historic Site

25. Species diversity at trapping and indirect measure sampling stations during the 2004 mammal inventory at Saint-Gaudens National Historic Site

26. Locations of remote cameras and other detection devices, trapping equipment, and orientation of small-mammal trap lines used in the 2004 mammal inventory at Marsh-Billings-Rockefeller National Historical Park.

27. Species diversity at trapping and indirect measure sampling stations during the 2004 mammal inventory at Marsh-Billings-Rockefeller National Historical Park.

28. Locations of remote cameras and other detection devices, trapping equipment, and orientation of small-mammal trap lines used in the 2004 mammal inventory at Saratoga National Historical Park.

29. Species diversity at trapping and indirect measure sampling stations during the 2004 mammal inventory at Saratoga National Historical Park.

30. Locations of remote cameras and other detection devices used in the 2004 mammal inventory at Acadia National Park (Mount Desert Island-west)

31. Locations of remote cameras and other detection devices used in the 2004 mammal inventory at Acadia National Park (Mount Desert Island-east)

32. Species diversity at indirect measure sampling stations during the 2004 mammal inventory at Acadia National Park (Mount Desert Island-west)

33. Species diversity at indirect measure sampling stations during the 2004 mammal inventory at Acadia National Park (Mount Desert Island-east).

34. Locations of remote cameras and other detection devices, trapping equipment, and orientation of small-mammal trap lines used in the 2004 mammal inventory at Sagamore Hill National Historic Site

35. Species diversity at trapping and indirect measure sampling stations during the 2004 mammal inventory at Sagamore Hill National Historic Site. 


\section{Tables}

1. The number of mammal species that theoretically could occur in each of 10 project parks and the 90 percent documentation goal established by the National Park Service Inventory and Monitoring Program.

2. Geographic information system (GIS) data layers used to develop strata for parks in the Northeast Temperate Network and Sagamore Hill National Historic Site mammal inventory

3. Temporal sampling scheme used in the mammal inventory at parks in the Northeast Temperate Network and Sagamore Hill National Historic Site

4. Indirect measure (IM) and trap station numbers, community type, GPS locations of the camera at IM stations and the start of the Longworth trap line, orientation of IM stations, and bearing of trap lines used in the 2004 mammal inventory at Weir Farm National Historic Site.

5. Community type associations of mammals detected at Weir Farm National Historic Site by indirect measure sampling, trapping, and observation ...

6. Mammal species detection rates and site occupancy at eight indirect measure stations at Weir Farm National Historic Site during two sampling sessions in 2004 ......19

7. Mammal capture rates and site occupancy for eight trapping stations (four with fox-sized live traps) at Weir Farm National Historic Site during sampling session 1 (1/20/2004-2/7/2004)

8. Mammal capture rates and site occupancy for eight trapping stations (four with fox-sized live traps) at Weir Farm National Historic Site during sampling session 2 (6/7/2004-6/22/2004)

9. Number of mammal specimens in museum collections and their proximity to Weir Farm National Historic Site.

10. Indirect measure (IM) and trap station numbers, community type, GPS locations of the camera at IM stations and beginning of the Longworth trap lines, orientation of IM stations, and bearing of trap lines at Morristown National Historical Park.

11. Community type associations of mammals detected at Morristown National Historical Park by indirect measure sampling, trapping, and observation

12. Mammal species detection rates and site occupancy at 11 indirect measure stations at Morristown National Historical Park during two sampling sessions in 2004.

13. Mammal capture rates and site occupancy for 11 trapping stations (6 with foxsized live traps) at Morristown National Historical Park during sampling session 2 (6/21/2004-7/7/2004)

14. Number of mammal specimens in museum collections and their proximity to Morristown National Historical Park.

15. Indirect measure (IM) and trap station numbers, community type, GPS locations of the camera at IM stations and beginning of the Longworth trap lines, orientation of IM stations, and bearing of trap lines at Roosevelt-Vanderbilt National Historic Sites

16. Community type associations of mammals detected at Vanderbilt Mansion National Historic Site by indirect measure sampling, trapping, and observation

17. Community type associations of mammals detected at Home of Franklin D. Roosevelt National Historic Site by indirect measure sampling, trapping, and observation 39

18. Community type associations of mammals detected at Eleanor Roosevelt National Historic Site by indirect measure sampling, trapping, and observation 
19. Mammal species detection rates and site occupancy at 12 indirect measure stations at Roosevelt-Vanderbilt National Historic Site during two sampling sessions in 2004

20. Mammal capture rates and site occupancy for 11 trapping stations (6 with fox-sized live traps) at Roosevelt-Vanderbilt National Historic Site during sampling session 2 (8/2/2004-8/18/2004).

21. Number of mammal specimens in museum collections and their proximity to Roosevelt-Vanderbilt National Historic Sites.

22. Indirect measure (IM) and trap station numbers, community type, GPS locations of the camera at IM stations and beginning of the Longworth trap lines, orientation of IM stations, and bearing of trap lines at Minute Man National Historical Park.

23. Community type associations of mammals detected at Minute Man National Historical Park by indirect measure sampling, trapping, and observation...

24. Mammal species detection rates and site occupancy at 12 indirect measure stations at Minute Man National Historical Park during two sampling sessions in 2004.

25. Mammal capture rates and site occupancy for 10 trapping stations (6 with foxsized live traps) at Minute Man National Historical Park during sampling session 2 (7/19/2004-8/2/2004).

26. Number of mammal specimens in museum collections and their proximity to Minute Man National Historical Park.

27. Locations of sampling equipment used for the mammal inventory at Saugus Iron Works National Historic Site and the community type where equipment was located

28. Community type associations of mammals detected at Saugus Iron Works National Historic Site by indirect measure sampling, trapping, and observation....

29. Mammal species detection rates and site occupancy at two indirect measure stations at Saugus Iron Works National Historic Site during two sampling sessions in 2004

30. Mammal capture rates and site occupancy for two trapping stations at Saugus Iron Works National Historic Site during sampling session 2 (9/20/2004-10/4/2004) .....61

31. Number of mammal specimens in museum collections and their proximity to Saugus Iron Works National Historic Site.

32. Indirect measure (IM) and trap station numbers, community type, GPS locations of the camera at IM stations and beginning of the Longworth trap lines, orientation of IM stations, and bearing of trap lines at Saint-Gaudens National Historic Site

33. Community type associations of mammals detected at Saint-Gaudens National Historic Site by indirect measure sampling, trapping, and observation . .66

34. Mammal species detection rates and site occupancy at 11 indirect measure stations at Saint-Gaudens National Historic Site during two sampling sessions in 2004

35. Mammal capture rates and site occupancy for 10 trapping stations (6 with foxsized live traps) at Saint-Gaudens National Historic Site during sampling session 2 (9/27/2004-10/22/2004).

36. Number of mammal specimens in museum collections and their proximity to Saint-Gaudens National Historic Site

37. Indirect measure (IM) and trap station numbers, community type, GPS locations of the camera at IM stations and beginning of the Longworth trap lines, orientation of IM stations, and bearing of trap lines at Marsh-Billings-Rockefeller National Historical Park 
38. Community type associations of mammals detected at Marsh-Billings-Rockefeller National Historical Park by indirect measure sampling, trapping, and observation........75

39. Mammal species detection rates and site occupancy at 14 indirect measure stations at Marsh-Billings-Rockefeller National Historical Park during two sampling sessions in 2004

40. Mammal capture rates and site occupancy for 12 trapping stations ( 6 with fox-sized live traps) at Marsh-Billings-Rockefeller National Historical Park during sampling session $2(10 / 12 / 2004-10 / 26 / 2004)$

41. Number of mammal specimens in museum collections and their proximity to Marsh-Billings-Rockefeller National Historical Park

42. Indirect measure (IM) and trap station numbers, community type, GPS locations of the camera at IM stations and beginning of the Longworth trap lines, orientation of IM stations, and bearing of trap lines at Saratoga National Historical Park.

43. Community type associations of mammals detected at Saratoga National Historical Park by indirect measure sampling, trapping, and observation

44. Mammal species detection rates and site occupancy at 16 indirect measure stations at Saratoga National Historical Park during two sampling sessions in 2004

45. Mammal capture rates and site occupancy for 12 trapping stations (8 with foxsized live traps) at Saratoga National Historical Park during sampling session 2 (11/1/2004-11/22/2004)

46. Mammal specimens in museum collections and their proximity to Saratoga National Historical Park.

47. Mammal species identified in other studies at Acadia National Park.

48. Indirect measure (IM) station numbers, community type, GPS locations of the camera at IM stations, and orientation of IM stations at Acadia National Park

49. Community type associations of mammals detected at Acadia National Park by indirect measure sampling, trapping, and observation.

50. Mammal species detection rates and site occupancy at 12 indirect measure stations at Acadia National Park during one sampling session in 2004

51. Number of mammal specimens in museum collections and their proximity to Acadia National Park

52. Indirect measure (IM) and trap station numbers, community type, GPS locations of the camera at IM stations and beginning of the Longworth trap lines, orientation of IM stations, and bearing of trap lines at Sagamore Hill National Historic Site.........101

53. Community type associations of mammals detected at Sagamore Hill National Historic Site by indirect measure sampling, trapping, and observation . .103

54. Mammal species detection rates and site occupancy at seven indirect measure stations at Sagamore Hill National Historic Site during two sampling sessions in 2004 .

55. Mammal capture rates and site occupancy for seven trapping stations (four with fox-sized live traps) at Sagamore Hill National Historic Site during sampling session $2(11 / 16 / 2004-11 / 23 / 2004)$

56. Mammal specimens in museum collections and their proximity to Sagamore

Hill National Historic Site 


\section{Conversion Factors and Datums}

\begin{tabular}{lll}
\hline \multicolumn{1}{c}{ Multiply } & \multicolumn{1}{c}{ By } & \multicolumn{1}{c}{ To obtain } \\
\hline \multicolumn{1}{c}{ Length } \\
\hline inch (in.) & 2.54 & centimeter $(\mathrm{cm})$ \\
foot (ft) & 0.3048 & meter $(\mathrm{m})$ \\
mile (mi) & 1.609 & kilometer $(\mathrm{km})$ \\
yard (yd) & 0.9144 & meter $(\mathrm{m})$ \\
\hline \multicolumn{1}{c}{ Area } & \\
\hline acre & $4,047 \quad 0.4047$ & square meter $\left(\mathrm{m}^{2}\right)$ \\
acre & 0.004047 & hectare $(\mathrm{ha})$ \\
acre & 0.09290 & square kilometer $\left(\mathrm{km}^{2}\right)$ \\
square foot $\left(\mathrm{ft}^{2}\right)$ & 259.0 & square meter $\left(\mathrm{m}^{2}\right)$ \\
square mile $\left(\mathrm{mi}^{2}\right)$ & 2.590 & hectare $($ ha) \\
square mile $\left(\mathrm{mi}^{2}\right)$ & & square kilometer $\left(\mathrm{km}^{2}\right)$ \\
\hline
\end{tabular}

Temperature in degrees Celsius $\left({ }^{\circ} \mathrm{C}\right)$ may be converted to degrees Fahrenheit $\left({ }^{\circ} \mathrm{F}\right)$ as follows:

${ }^{\circ} \mathrm{F}=\left(1.8 \times{ }^{\circ} \mathrm{C}\right)+32$

Horizontal coordinate information is referenced to the North American Datum of 1983 (NAD 83). 


\title{
An Inventory of Terrestrial Mammals at National Parks in the Northeast Temperate Network and Sagamore Hill National Historic Site
}

\author{
By Andrew T. Gilbert, Allan F. O'Connell, Jr., Elizabeth M. Annand, Neil W. Talancy, John R. Sauer, \\ and James D. Nichols
}

\begin{abstract}
An inventory of mammals was conducted during 2004 at nine national park sites in the Northeast Temperate Network (NETN): Acadia National Park (NP), Marsh-Billings-Rockefeller National Historical Park (NHP), Minute Man NHP, Morristown NHP, Roosevelt-Vanderbilt National Historic Site (NHS), Saint-Gaudens NHS, Saugus Iron Works NHS, Saratoga NHP, and Weir Farm NHS. Sagamore Hill NHS, part of the Northeast Coastal and Barrier Network (NCBN), was also surveyed. Each park except Acadia NP was sampled twice, once in the winter/spring and again in the summer/fall. During the winter/spring visit, indirect measure (IM) sampling arrays were employed at 2 to 16 stations and included sampling by remote cameras, cubby boxes (covered trackplates), and hair traps. IM stations were established and re-used during the summer/fall sampling period. Trapping was conducted at 2 to 12 stations at all parks except Acadia NP during the summer/ fall period and consisted of arrays of small-mammal traps, squirrel-sized live traps, and some fox-sized live traps. We
\end{abstract}

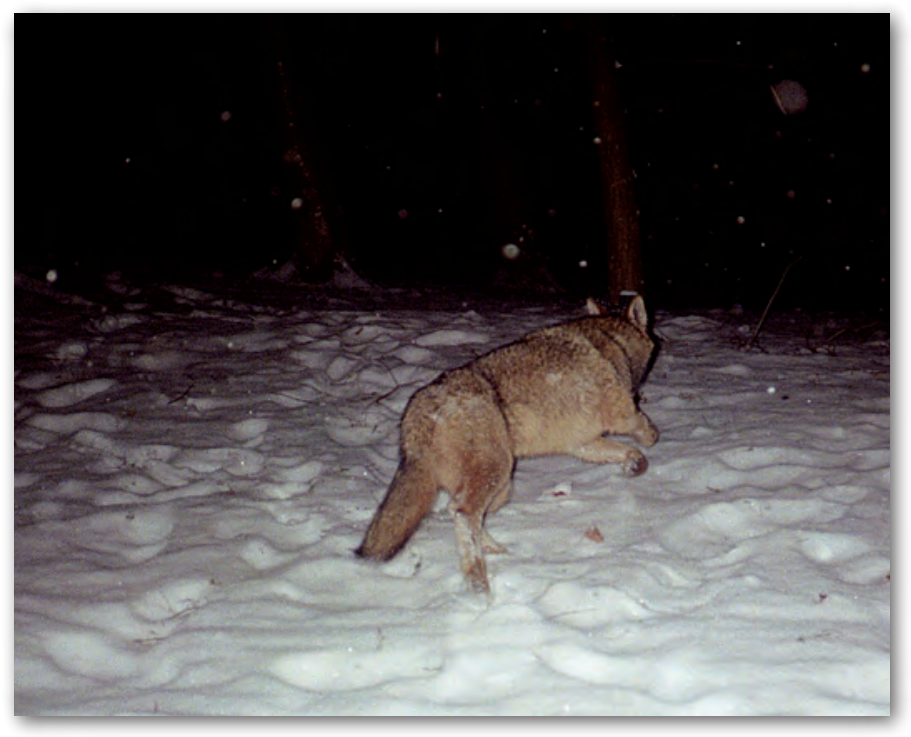

used estimation-based procedures and probabilistic sampling techniques to design this inventory. A total of 38 species was detected by IM sampling, trapping, and field observations. Species diversity (number of species) varied among parks, ranging from 8 to 24, with Minute Man NHP having the most species detected. Raccoon (Procyon lotor), Virginia Opossum (Didelphis virginiana), Fisher (Martes pennanti), and Domestic Cat (Felis silvestris) were the most common medium-sized mammals detected in this study and White-footed Mouse (Peromyscus leucopus), Northern Short-tailed Shrew (Blarina brevicauda), Deer Mouse (P. maniculatus), and Meadow Vole (Microtus pennsylvanicus) the most common small mammals detected. All species detected are considered fairly common throughout their range including the Fisher, which has been reintroduced in several New England states. We did not detect any state or federal endangered or threatened species.

\section{Introduction}

In 1999, the National Park Service (NPS) established a national strategy to institutionalize both inventory and monitoring of vertebrates and vascular plants so that sciencebased decisions could be made to protect and effectively manage park resources and in doing so created the Inventory and Monitoring (I\&M) Program (National Park Service, 1999b). One aspect of the NPS I\&M Program requires inventories to document occurrence (presence-absence) and, under certain circumstances, the abundance and distribution of vertebrates and vascular plant populations that occur within NPS boundaries (National Park Service, 1999a). As part of this effort, the U.S. Geological Survey (USGS), in cooperation with the NPS, conducted a baseline inventory of terrestrial mammals at nine parks (Acadia National Park (NP), MarshBillings-Rockefeller National Historical Park (NHP), Minute Man NHP, Morristown NHP, Roosevelt-Vanderbilt National Historic Site (NHS), Saint-Gaudens NHS, Saugus Iron Works NHS, Saratoga NHP, and Weir Farm NHS) in the Northeast 
Temperate Network (NETN) (Johnson and others, 2000) and Sagamore Hill NHS (fig. 1), a park located in the Northeast Coastal and Barrier Network (NCBN); hereafter, all study sites are referred to as project parks. Previous research on mammals had been conducted at some of these project parks, but these efforts were typically limited in scope, focusing on either individual species or issues of management concern to the NPS. With the exception of Acadia NP in Maine, quantitative information on mammals throughout the NETN and Sagamore Hill generally is lacking (Johnson and others, 2000). Nevertheless, mammals play an important role in most natural systems (Mech, 1996), and knowledge about the mammalian fauna found in national parks will allow managers to more effectively protect and, if the need arises, manage natural resources within NPS boundaries.

This report presents the results of an inventory of mammals conducted during 2004 at 10 national parks in the northeastern United States, describes the sampling methods used, discusses the results with respect to species that were expected but not detected and endangered and threatened species, and provides a list of historical voucher specimens for each park.

\section{Goals and Objectives}

The goal of this project is to help the NPS document 90 percent of the terrestrial mammal species expected to occur within project park boundaries at nine parks in the NETN and Sagamore Hill NHS (table 1). Based on a review of taxonomic and geographic references, 65 terrestrial mammal and bat species theoretically could occur in project parks (Godin, 1977; Degraff and Rudis, 1986; Whitaker and Hamilton, 1998). This number does not include marine mammals or terrestrial mammals extinct for more than 50 years in the region (for example, Woodland Caribou (Rangifer tarandus caribou), Mountain Lion (Puma concolor)). The specific objectives of this project were to (1) inventory terrestrial mammals by direct (trapping and incidental observations) and indirect (remote photography, tracks, and hair) means, (2) determine the distribution of mammals by vegetation community type surveyed, and (3) collect voucher specimens of mammals from each park.

\section{Physiography and Climate}

Project parks in this study, with the exception of Acadia NP, are small and do not contain large areas of significant natural resources. Like most natural areas in the highly urbanized northeastern United States, they are part of larger ecological communities that can greatly influence resources within park boundaries. Nevertheless, these parks can still be important reservoirs of biodiversity (Mitchell and others, 2006). Project parks occur within three major temperate eco- system provinces as described in the U.S. National Vegetation Classification (fig. 1; Mitchell and others, 2006). Acadia

NP is the only park that falls within the Laurentian mixed forest class, a transitional region between the boreal forest to the north and the broadleaf deciduous forest to the south (McMahon, 1990). Acadia NP is unique in this region in that it contains substantial relief in a region generally dominated by low relief. The mountains of Acadia NP are famous and give the park its rugged beauty. Lakes and ponds are common on the landscape, as are many wetland types, including bogs, fens, and graminoid wetlands. The climate of Acadia NP is "cool, moist and maritime" (Patterson and others, 1983). Mean daytime temperatures range from $0{ }^{\circ} \mathrm{C}$ in January to $22^{\circ} \mathrm{C}$ in July and nighttime temperatures range from $-10^{\circ} \mathrm{C}$ in January to $14{ }^{\circ} \mathrm{C}$ in July (National Park Service, 2006). Precipitation occurs throughout the year, averaging $135 \mathrm{~cm}$ of rain and $156 \mathrm{~cm}$ of snow (National Park Service, 2006), with maximum precipitation occurring in summer (Bailey, 1995a).

The Adirondack-New England mixed forest ecoregion is similar to the Laurentian mixed forest, with the exception that much greater vertical relief results in greater variation among forest types by elevation. The characteristics of this region are driven largely by the dramatic topography of rugged mountains and broad valleys, a feature of a glacially active past. Lakes, ponds, and wetlands in general are also important in this region, but are not major components of MABI or SAGA. Small ponds are present at MABI (the Pogue) and SAGA (Blow-Me-Down Pond), as well as some small wetland areas, but they are not dominant landscape features. Climate is similar to that of the Laurentian mixed forest, except that precipitation tends to be more evenly distributed throughout the year (Bailey, 1995b).

Seven project parks are found in the eastern broadleaf forest ecoregion: MIMA, MORR, ROVA, SAHI, SAIR, SARA, and WEFA. The topography in this region is varied, but is characterized as coastal plain in the east, with elevations to $300 \mathrm{~m}$. Wetlands are limited in this region, but are more common in the north where glaciers have been active and where larger rivers or streams, such as the Hudson River (SARA) and the Concord River (MIMA), are located. Climate here is continental, with cold winters and warm summers. Precipitation is greatest in the summer (Bailey, 1995c).

Fields are an important feature of six of the seven eastern broadleaf forest parks (SAIR being the exception). The existence of fields in this region is a result of deforestation for farming during the $18^{\text {th }}$ and $19^{\text {th }}$ centuries, with peak deforestation occurring during 1820-1880 (Litvaitis, 1993), prior to the formal establishment of the parks. Land cleared for farming or logging is rapidly reverting to forest or becoming suburbanized (Foster, 1992; Litvaitis, 1993; Smith and others, 1993); in either case, the future existence of fields in this region is threatened by these processes.

At ACAD and SAHI, marine community types represent a substantial proportion of the natural resources and play an important role for marine organisms and other species that use the coastal community type. 


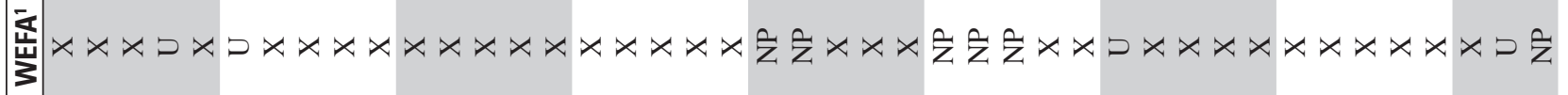

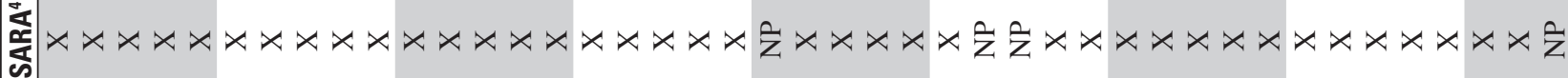

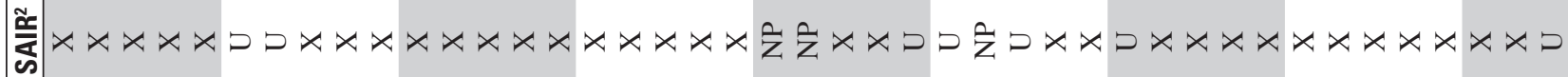

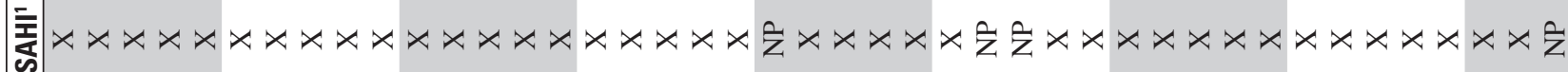

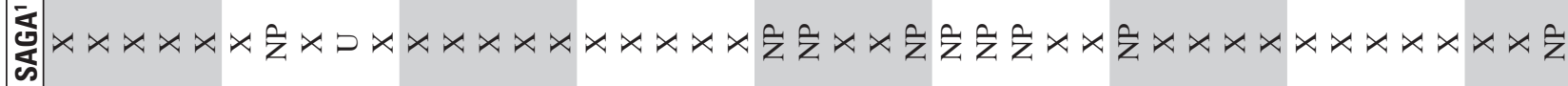

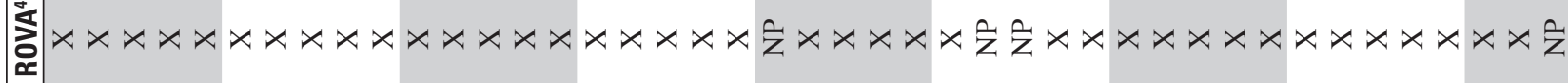
:

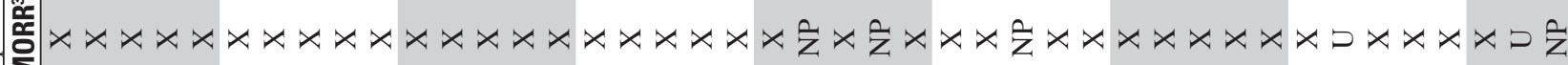

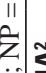

空

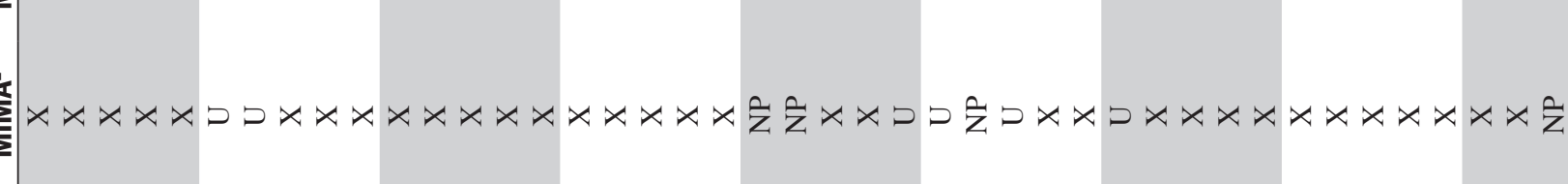
官

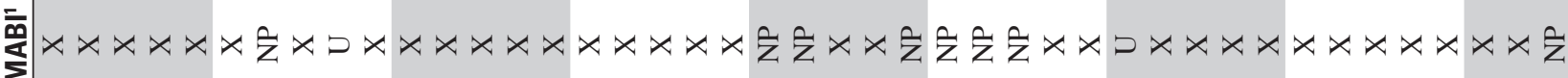
总宁 을 : ¿ 离

힌

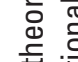

壳

.

흉
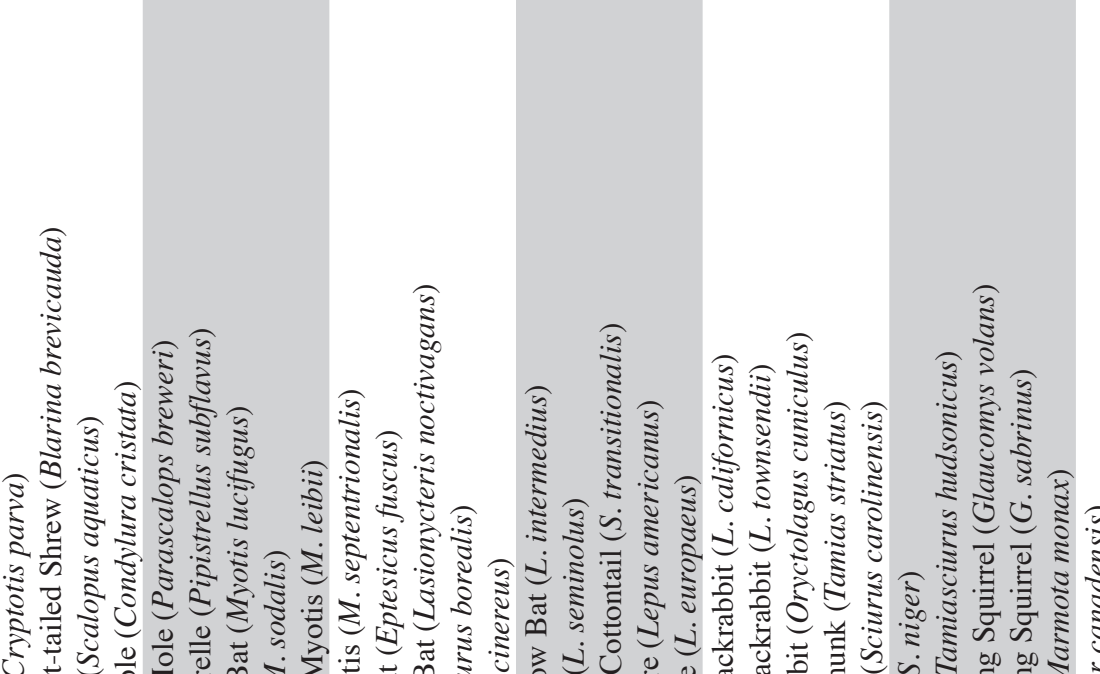

$\stackrel{\Phi}{\lessgtr}$

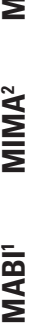




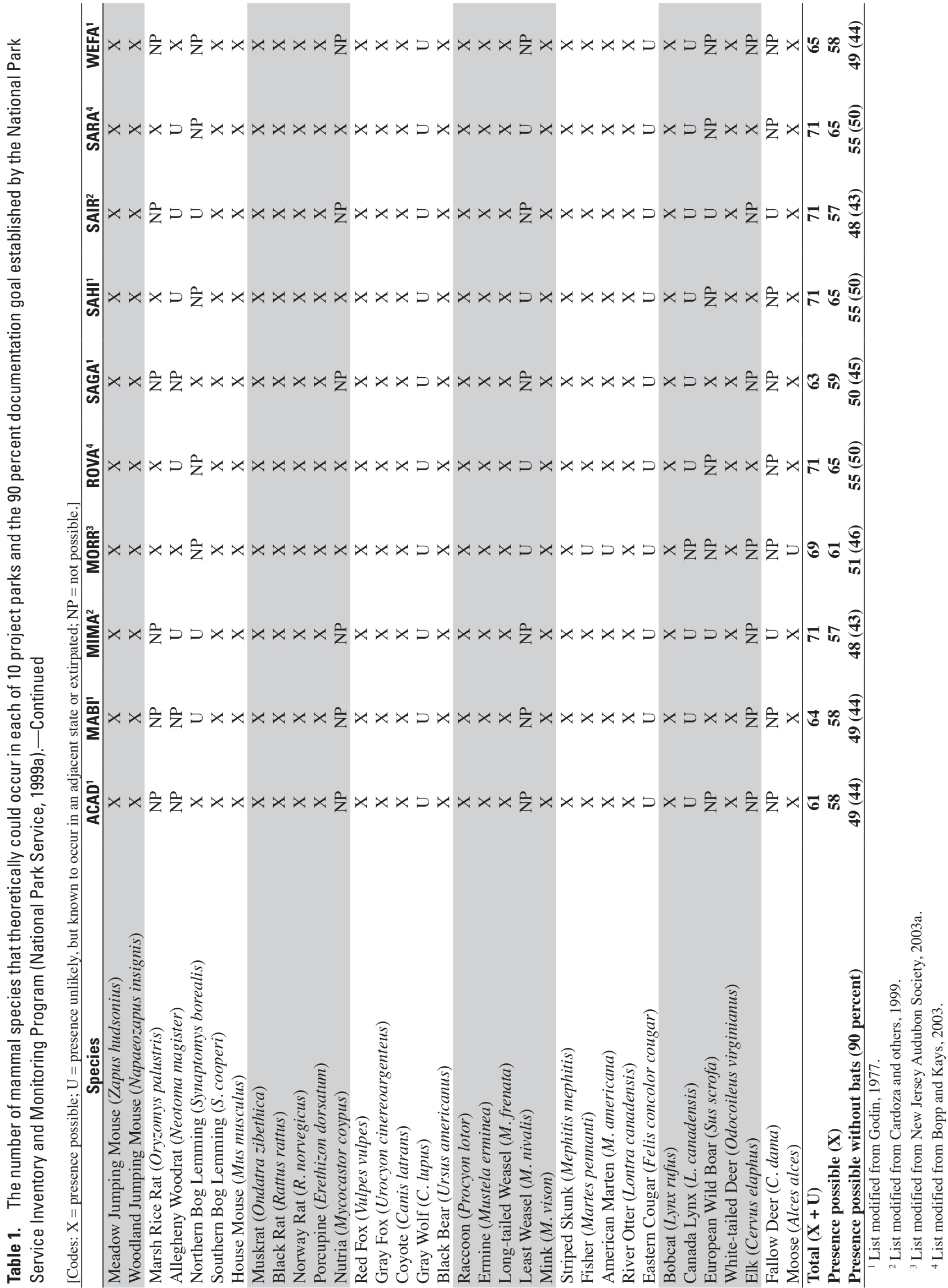




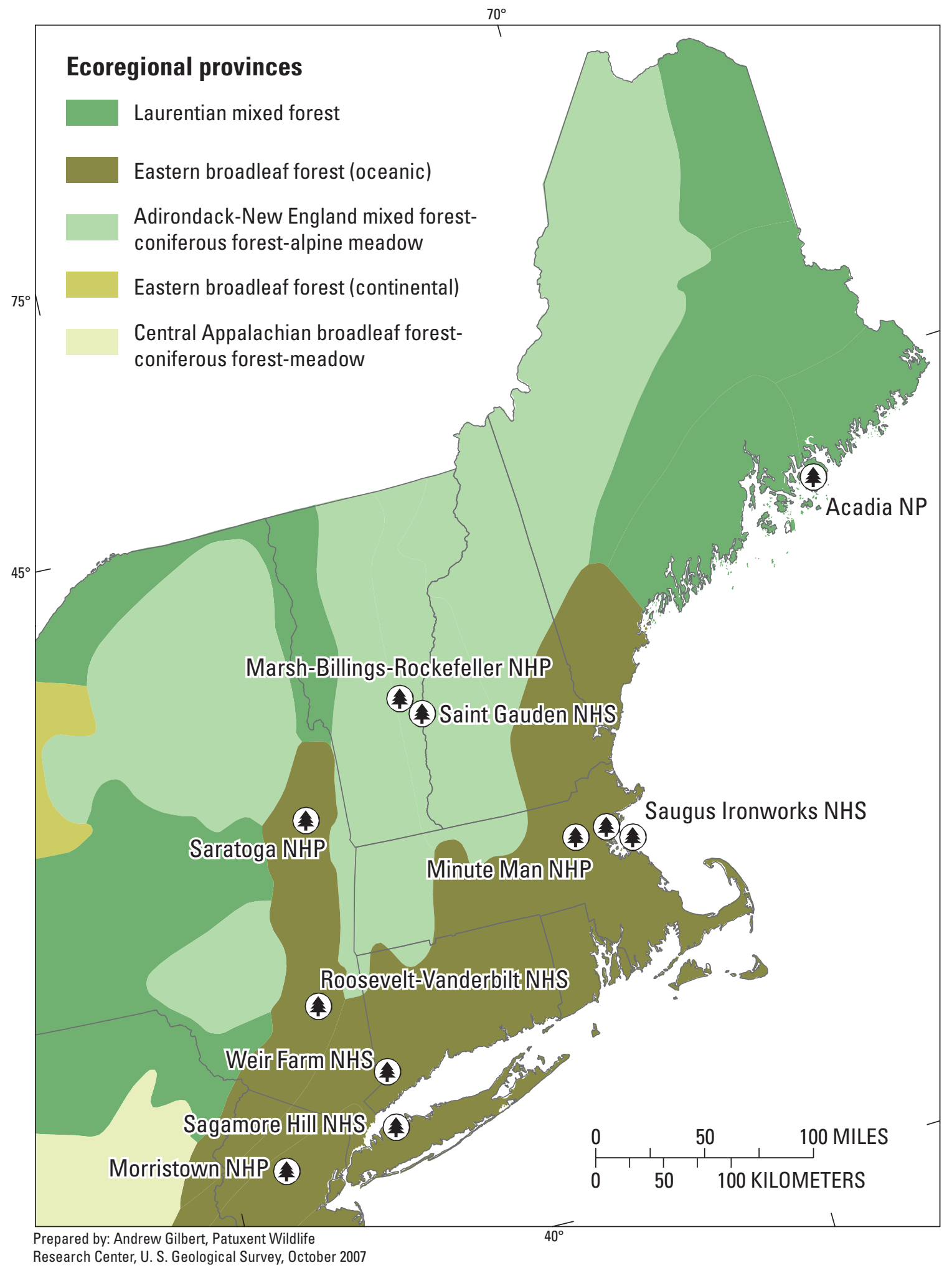

Figure 1. National Park units and representative ecoregions in the northeastern United States included in the 2004 mammal inventory of the Northeast Temperate Network and Sagamore Hill National Historic Site in the Northeast Coastal and Barrier Network. (NP = National Park; NHS = National Historic Site; NHP = National Historical Park.) 


\section{Historical Research, Surveys, and Inventories of Mammals}

Research, surveys, or inventories of mammals are limited for project parks except Acadia NP, where a number of projects have been conducted since the 1980s. The scope of work varies widely and, although a few general inventories have been conducted, investigations focusing on a single species or species group are more common as a result of NPS management needs. Notable studies at ACAD include inventories of terrestrial mammals and bats on Schoodic Peninsula (Glanz and Connery, 1999) and Isle au Haut (Cole, 1993) and research on carnivores (Harrison, 1989; Winter, 1990) and small mammals (Garman, 1991; Hazen and others, 1992; O'Connell and others, 2001) on Mount Desert Island (MDI). Among the other project parks, bat surveys have been conducted at MABI (Reynolds and McFarland, 2001) and MORR (Pipliski, 2002), and deer have been studied in several parks including MORR (Christie and Sayre, 1989; Underwood, 1997) and SARA (Underwood and others, 1994). Small mammals have been documented at SARA (Steblein and Mathews, 1987), ROVA (Steadman, 1991), and SAGA (Cook, 1985) to varying extents. Mammals were inventoried during the 1980s at SAGA as part of a larger effort to document vertebrates and other important resources (Cook, 1985). No prior studies of mammals have been conducted at SAHI, SAIR, or WEFA.

Mammal specimens have been collected by both scientists and lay people within the project parks and surrounding region since the 1800s. These specimens represent an important historical record of the mammalian fauna in the respective parks. Recently, voucher specimen data for vertebrates and vascular plants collected in or near northeastern national parks were gathered from natural history collections throughout North America and Europe (Gilbert and O'Connell, 2004; O'Connell and others, 2004). Mammal specimens were found for most parks. In some cases, these specimens may be the only record of historical biodiversity for that species for the project park or region. This type of information may be valuable for assessing historical changes and the current ecological condition of park resources.

\section{Methods}

\section{Approach to Inventory Design}

Biological inventories are fundamental surveys that generate presence or absence information about a species from a collection of sampling units (MacKenzie and others, 2006) and often serve as the first step in assessing biodiversity. Over the last decade there has been growing international interest in biological inventories followed by the development of monitoring programs as a way to track changes in populations

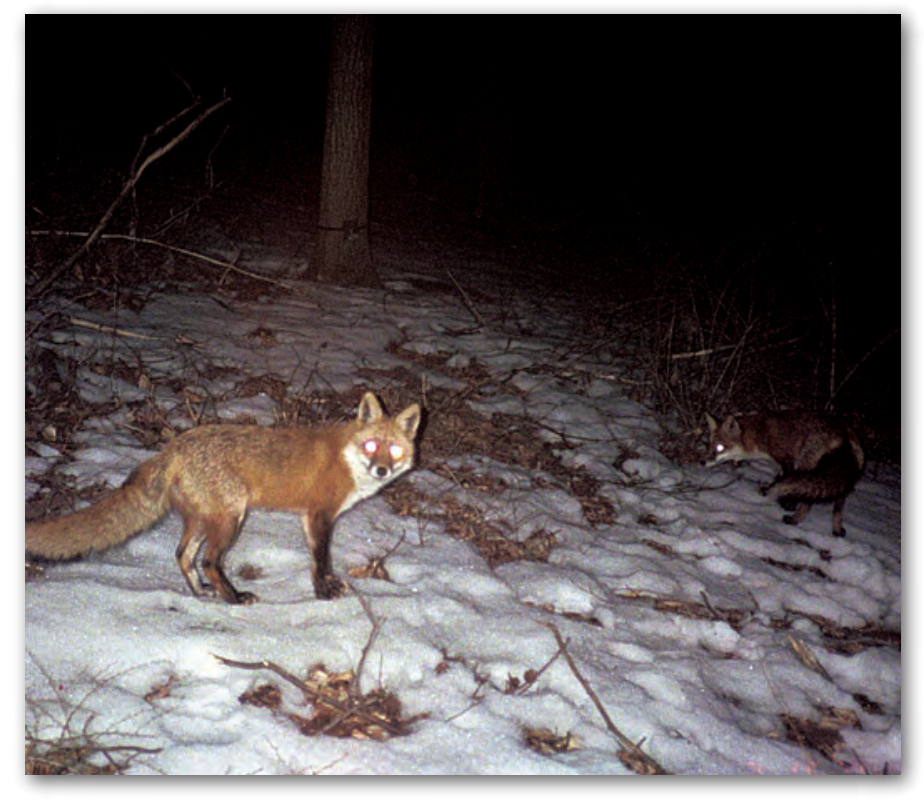

(Buckland and others, 2005). All too often, however, programs are implemented without considering the fundamental questions that surround detecting change (Yoccoz and others, 2001; Nichols and Williams, 2006). Accurate, science-based inventories can provide a foundation for credible monitoring programs, but scientists, practitioners, and administrators must realize that detecting change is difficult and requires the use of robust analytical procedures (Field and others, 2007). To provide a science-based, credible foundation for long-term monitoring we designed these inventories using estimationbased procedures (Goebel and Baker, 1982; Boulinier and others, 1998; Nichols and others, 1998) and probabilistic sampling methods that will allow future studies and surveys to easily resample should they choose to do so.

Inventories of an entire class of animals are difficult to achieve in a single project. The Class Mammalia includes nearly 5,000 species, more than 100 of which can be found in the eastern United States (Whitaker and Hamilton, 1998). Even the simple documentation of this number of species at multiple sites requires substantial resources. Inventories, surveys, or research are commonly initiated for threatened or endangered mammals or large species of public interest, but generic inventories rarely receive the attention and commitment that are necessary to ensure adequate sampling of all species groups in all major community types. Inadequate or convenience sampling (for example, one or two cameras, collection of road kill carcasses) provides only limited results that are not true inventories in that they do not completely sample the target population in a study area. To sample multiple species we used an array of devices that could be deployed simultaneously (O'Connell and others, 2006; Nichols and others, 2008). This approach minimized both effort and cost, two factors that commonly limit the amount of information that can be collected. 
We chose occupancy (occurrence) as our state variable because occupancy met the inventory goals of the NPS I\&M Program to document terrestrial mammals that inhabit our study areas. Additionally, we designed our inventory to accommodate both spatial variability and detection issues in future monitoring efforts. Meaningful estimates of detectability could have been generated from our data but were beyond the scope of this work (see MacKenzie and others, 2002; 2003; 2006; and Royle and Nichols, 2003, for examples and a review of the topic). If long-term monitoring programs are needed to track changes in populations over time and (or) space, appropriate design considerations can be used to allocate samples and effort (Pollock and others, 2002; MacKenzie and Royle, 2005; O'Connell and others, 2006). Specific methods used in this study are provided below.

\section{Spatial Sampling Design and Sampling-Point Allocation}

We implemented a stratified random-start systematic sampling design at all project parks. This design has the benefit of being spatially balanced and relatively easy to implement (Geissler and McDonald, 2003), and stratification makes certain that spatially limited (rare) community types are sampled. Sampling-point allocation followed the methodology specified by Geissler and McDonald (2003) for use in NPS inventory and monitoring projects (Fancy, 2000).

We developed two programs using ArcObjects for ArcGIS 8.3 to automate sampling-point generation. The first program generated a grid of specified size and random origin (app.A). The second program identified all cells in the stratum of interest and systematically drew sampling points based on the specified number of points desired (app. B). Strata were assigned outside ArcGIS using Microsoft Excel spreadsheet functions and imported back to the grid to be used by the second program (app. C).

\section{Stratification}

We defined strata by major vegetative community types (hereafter these are referred to as community types), wetlands, and riparian areas, resulting in a distribution of sampling points among all major community types, except at ACAD, where sampling points were confined to selected strata based on consultation with park staff. We imported spatial data layers (table 2) into a geographic information system (GIS) database using ArcGIS 8.3 (Environmental Systems Research Institute (ESRI), Inc., Redlands, Cal.). We digitized aerial photographs when vegetation cover maps were unavailable for a park and updated older vegetation cover maps by digitizing more current aerial photography. We buffered streams by 20 $\mathrm{m}$ on each side to adequately sample riparian areas. Riparian areas were not generated for ACAD (because they were not a community type of interest) or for MIMA (because stream data were unavailable).

\section{Systematic Sampling Scheme}

We used a sampling method that divided each park into grid cells (25-100 m on a side) to which we assigned strata (fig. 2). First, a 100-m grid was generated for each park, except SAIR $(25 \mathrm{~m})$ and WEFA $(50 \mathrm{~m})$. We used the boundary of each park as the limit of the sampling area for which we generated the grid cells. The program randomly placed a grid of cells beginning at the southwest corner of the map extent and proceeding toward the northeast corner. Initial randomization was achieved by randomly locating the lower left corner of the grid within one cell length $(25-100 \mathrm{~m})$ in both $\mathrm{N}-\mathrm{S}$ and E-W directions. A dense grid of cells was created to cover the smallest rectangle that could contain the park (map extent), but only those cells whose centers were within the park boundary were kept.

Next, we assigned each grid cell a stratum type based on the majority proportion (by area) of all strata within each grid cell. To do this, we performed a clipping operation in ArcMap that divided all strata into small polygons within each grid cell. We exported the area data created by this operation in ArcMap to Microsoft Excel to calculate the percentage of each stratum in every grid cell. A simple formula was used to determine the stratum having the largest proportion in each grid cell and assign these results to the grid cells. The results from Microsoft Excel were imported back into ArcMap to be used by the second program for generating systematic sampling points.

The sampling program generated systematic sampling points for each stratum based on the number of grid cells in each stratum and the number of sampling points desired. The program implemented a systematic design by first dividing the total number of grid cells assigned to a stratum by the number of sampling points required. We denote this value as the sampling frame length. Next, the program selected a random starting cell between cell 1 and the length of the sampling frame. Finally, points were placed beginning at the sampling frame length and at grid cells every frame length until all desired sampling points were assigned.

For example, in figure 3 the conifer stratum (dark green) was assigned to 26 cells and we required seven sampling points to be drawn for the conifer stratum, resulting in a sampling frame length of 3.7 (26/7). Therefore, a sampling point would be placed every 3.7 cells, beginning with a random starting cell between 1 and 4 . The program progresses geographically cell to cell from southwest to northeast across the map so that proper spacing is maintained among all points.

\section{Assigning Sampling Points}

We assigned two indirect measure (IM) stations (each station includes a camera, two hair traps, and two trackplates) (O'Connell and others, 2006) and two trapping stations for each pre-determined stratum or up to the maximum number of grid cells in a stratum. Initially, we planned to sample in four seasons and rotate equipment to different sampling locations 


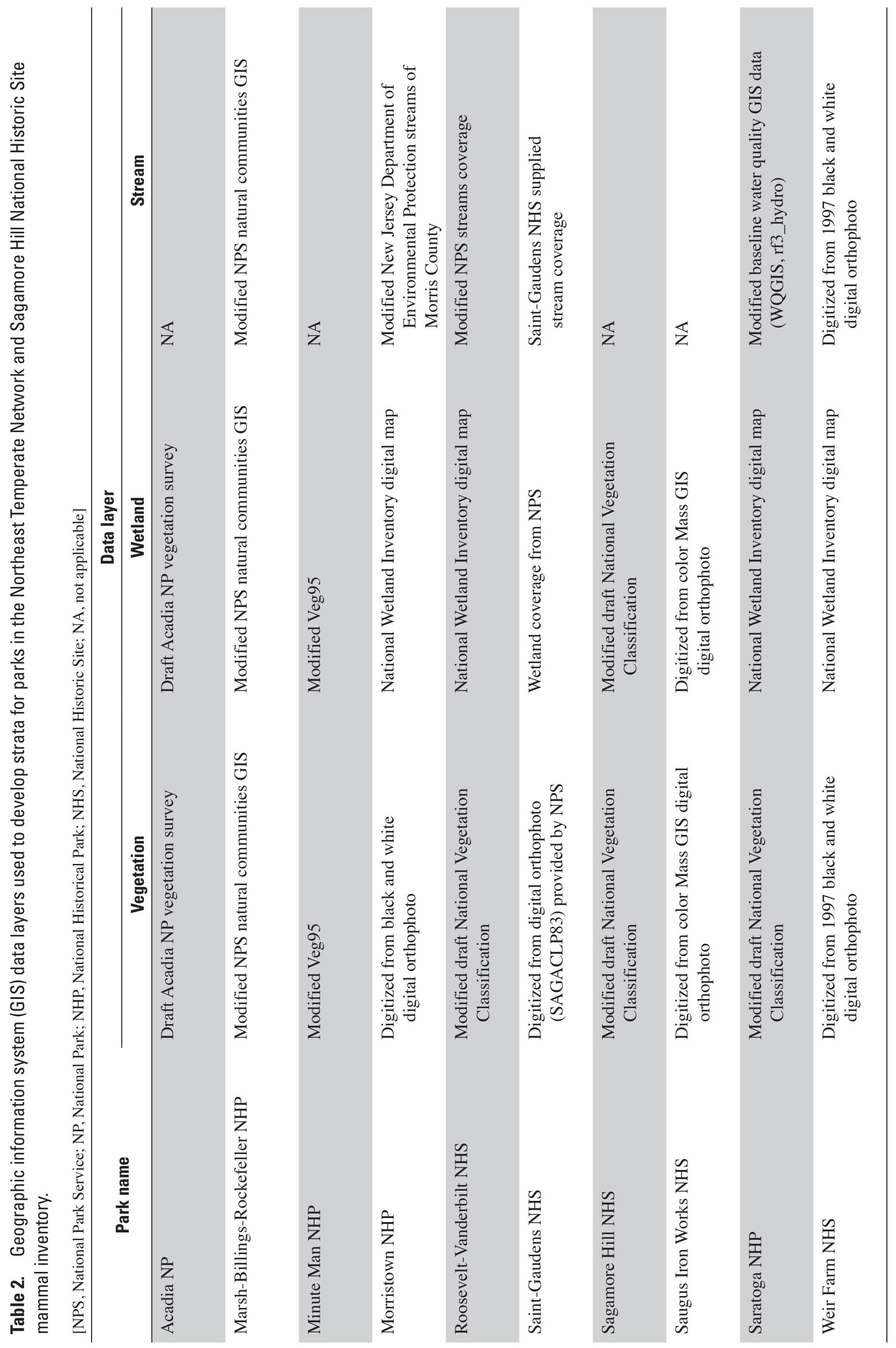




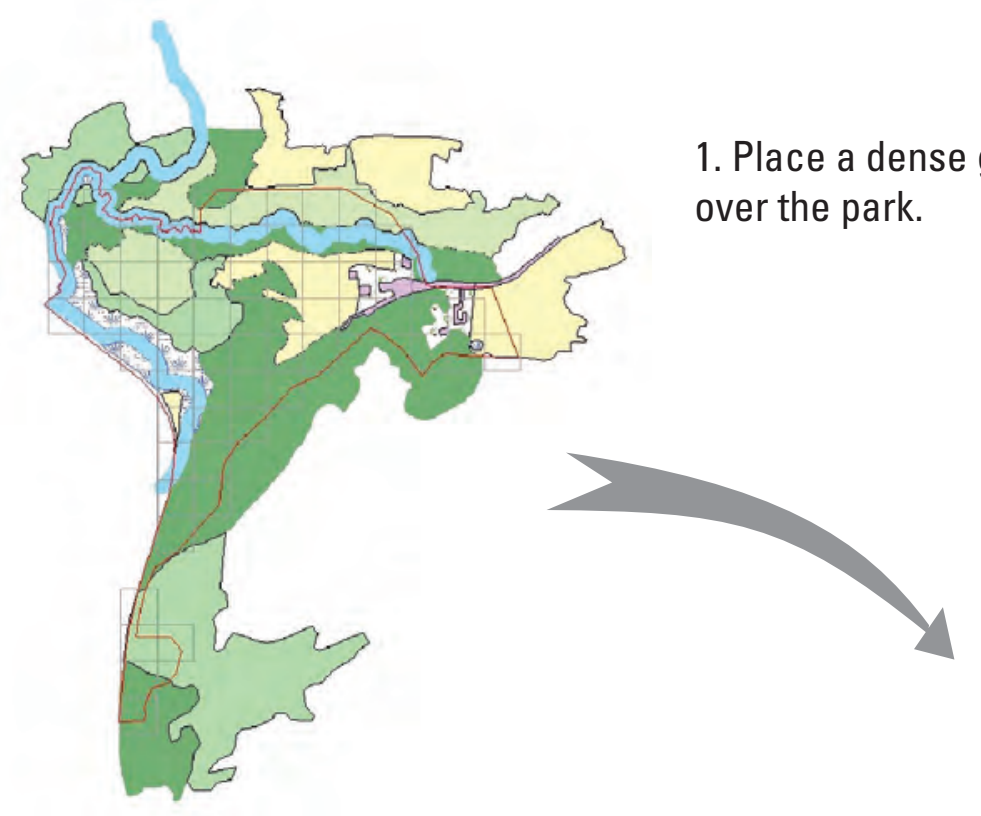

2. Determine the major strata type within each cell to assign each cell to a stratum.
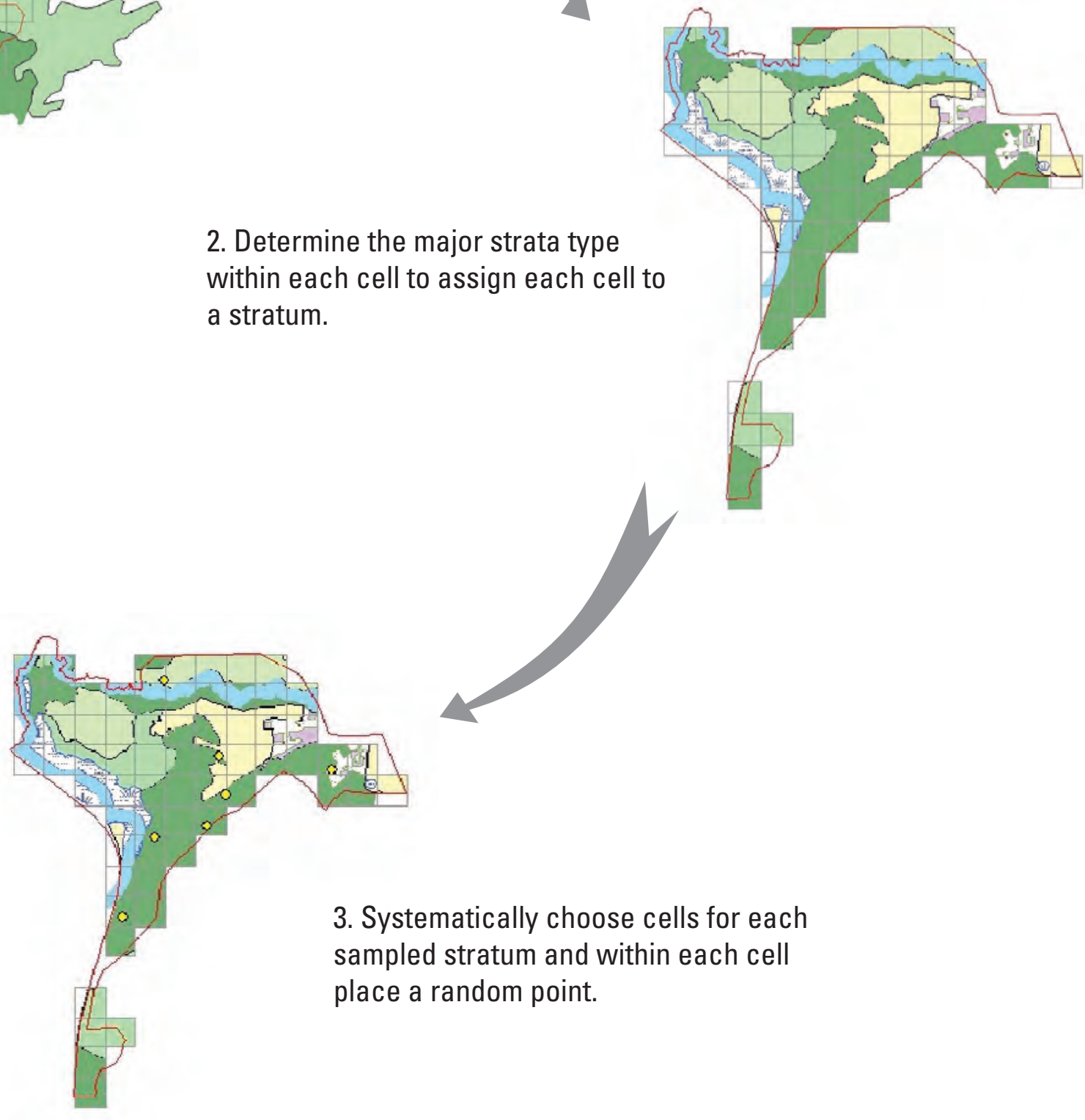

3. Systematically choose cells for each sampled stratum and within each cell place a random point.

Figure 2. Steps used to select sampling points for the 2004 mammal inventory using a grid system, vegetation strata, and random point placement. 


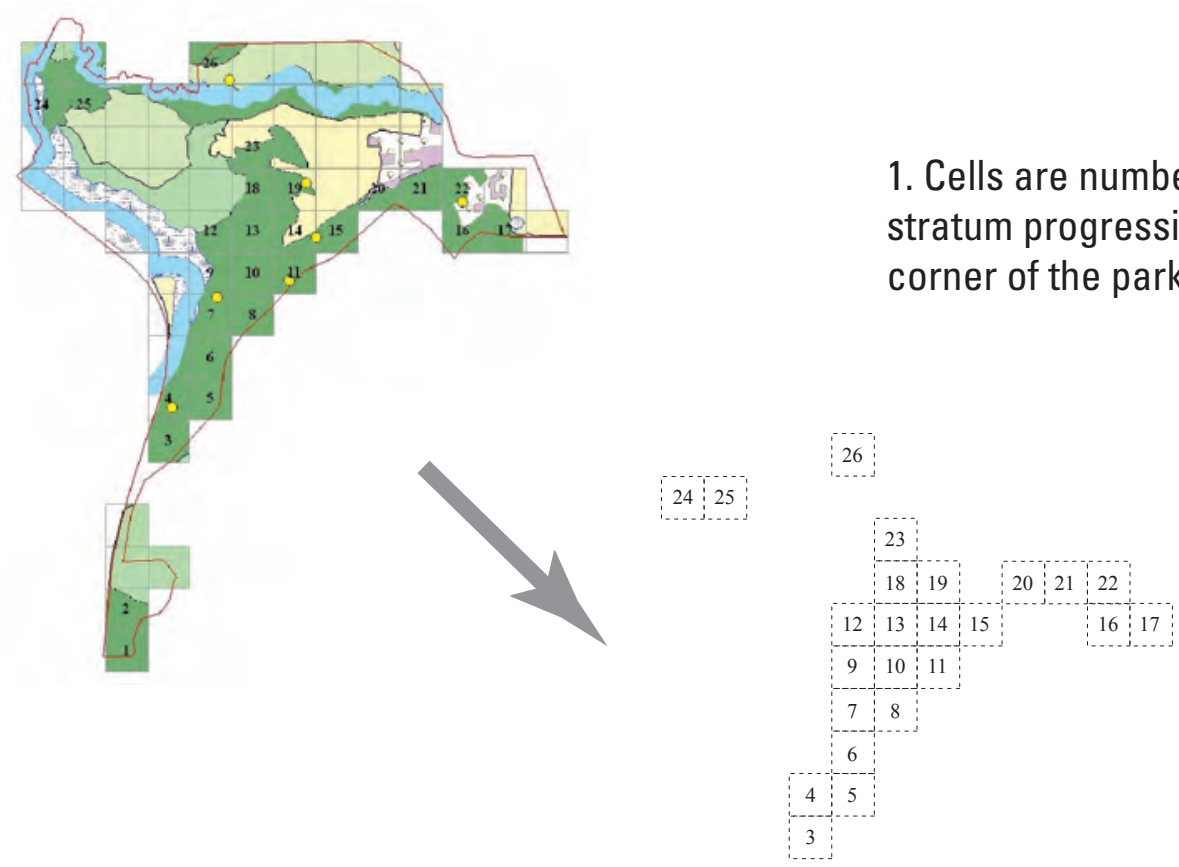

2. The sampling frame is calculated:

= (\# cells / \# sampling points)

Example: 26 cells $/ 7$ sampling points $=3.7$ cells/sampling point

3. Sampling points are assigned to the cell encountered at the end of the frame, beginning with a random starting cell and progressing every 3.7 cells until all 7 sampling points are assigned.

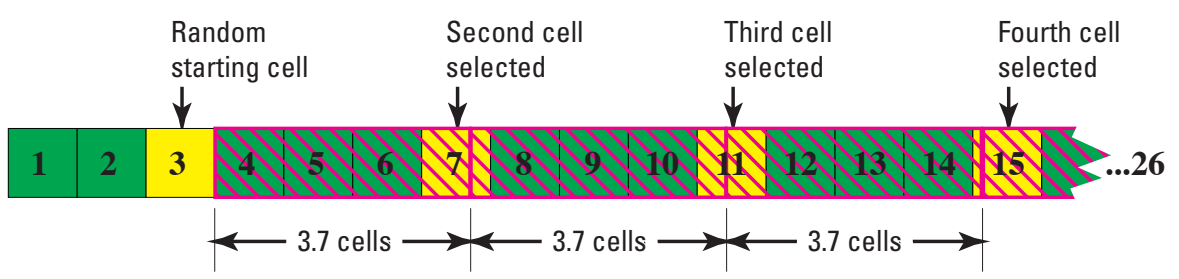

Figure 3. Steps used to calculate the sampling frame and assign sampling points for the 2004 mammal inventory. 
each season, resulting in a total of 16 locations for each stratum (four stations per season times four seasons). We reduced the number of sampling sessions to two and also decided to keep equipment in the same location for both sampling sessions because of time constraints. Therefore, although we generated as many as 16 sampling points per stratum, we actually used no more than 4 . We systematically chose sets of 4 points from the 16 by selecting every fourth station (for example, 1 , $5,9,13$ ) and using a set of four as the basis for sampling.

Occasionally, we were unable to generate 16 sampling points because fewer than 16 grid cells were assigned to a stratum. However, because we used only four sampling points, this typically was not a problem unless the program generated fewer than four sampling points. In several instances, the program assigned fewer than four grid cells to a stratum and, consequently, that stratum had fewer than the maximum of four stations. The two trapping and two IM stations were randomly assigned to the four sampling points. We sometimes used one of the other 12 unused sampling points if we encountered a site where it was impossible to locate equipment because of concerns about the security of equipment and (or) visitor disruption. In these instances, we used the next closest point. In some parks, the number of trapping stations was reduced to less than the full sampling regime (two per stratum) because we could not logistically maintain more than 12 trapping stations per park. In these instances, we made sure to include at least one station in each stratum and randomly determined in which strata to place additional sets of trapping equipment.

We used the true (geographic) location of sampling points as designated by the sample selection program, but in some cases the program placed points outside the target community type (stratum). First, as previously noted, we assigned a community type to a grid cell if it constituted the majority percentage of the community in that cell. Nevertheless, there were often other community types within a cell and, because sampling-point allocation was random within the grid cell and not the community, the community type where the sampling point was located may have been different than that originally assigned to the cell. Using smaller grid-cell sizes minimized this discrepancy, but did not eliminate it. Second, community type features were sometimes misidentified on the digital map layer. In either case, we did not reassign sampling points.

Once on site, we recorded the community type for the location of each IM device and trap line. This community type classification was sometimes different from the stratum designation because of the reasons described above. Thus, we determined species-community type associations using classifications recorded from the locations of each detection device (trackplate, cubby box, remote camera) in our sampling array and not prior stratum designation or general station information. Although this method frequently resulted in unequal sampling effort in different community types, we believe linking species presence with local community type was the most accurate. We did not add sampling points to account for this inequity.

\section{Locating Sampling Points}

We located sampling points by global positioning system (GPS) to within 10 to $30 \mathrm{~m}$ of the true location (typical accuracy of handheld GPS). For IM stations, the remote camera location became the sampling point and we oriented all other devices in a circular fashion around that point (see fig. 4 for details). In a few cases, where the sampling point was close to the project park boundary and the cubby box or hair trap fell outside the boundary, we placed either device at the generated sampling point. Under such circumstances, we arranged the remainder of the sampling equipment within the boundary as described above. If the point fell outside the park boundary, we relocated the point to just within the boundary and arranged the sampling equipment as described above. We gave all cameras, cubby boxes, and hair traps a unique location identifier and located each device with a GPS. For trapping stations, we located the first trap on the small-mammal trap line at a specified sampling point. We then arranged all other traps relative to that point (fig. 5). We gave a unique location identifier to the starting point of each small-mammal trap line as well as each squirrel-sized and fox-sized trap. We recorded coordinates from GPS positioning.

\section{Temporal Sampling Scheme}

We sampled at each park twice in 2004 except Acadia NP, where we sampled only once. We divided sampling into winter/spring and summer/fall periods (sampling sessions 1 and 2, respectively). Because of time and manpower limitations and the long distances between parks, we sampled at parks in a manner that was most efficient for traveling. We also decided to begin sampling at parks in the south, traveling north as winter progressed into spring to avoid relatively difficult sampling conditions in the northern part of the NETN. This decision dictated when we conducted sampling in each project park and we carried this routine through to the second sampling session (table 3). We conducted IM sampling at all parks except ACAD during both sampling sessions. We visited ACAD only once during the first sampling session as a result of time and budget constraints. We trapped during sampling session 2 at all parks except ACAD and WEFA. We did not trap at ACAD but trapped in both sessions at WEFA. Initially, we intended to trap at all parks during session 1, but winter trapping proved difficult and dangerous, yielding too few captures to make trapping worthwhile. Trapping required an inordinate amount of time to set up and run trap lines, and raised the possibility of harm to both trapped animals and investigators. Therefore, WEFA was the first and only park in which we trapped during sessions 1 and 2. 


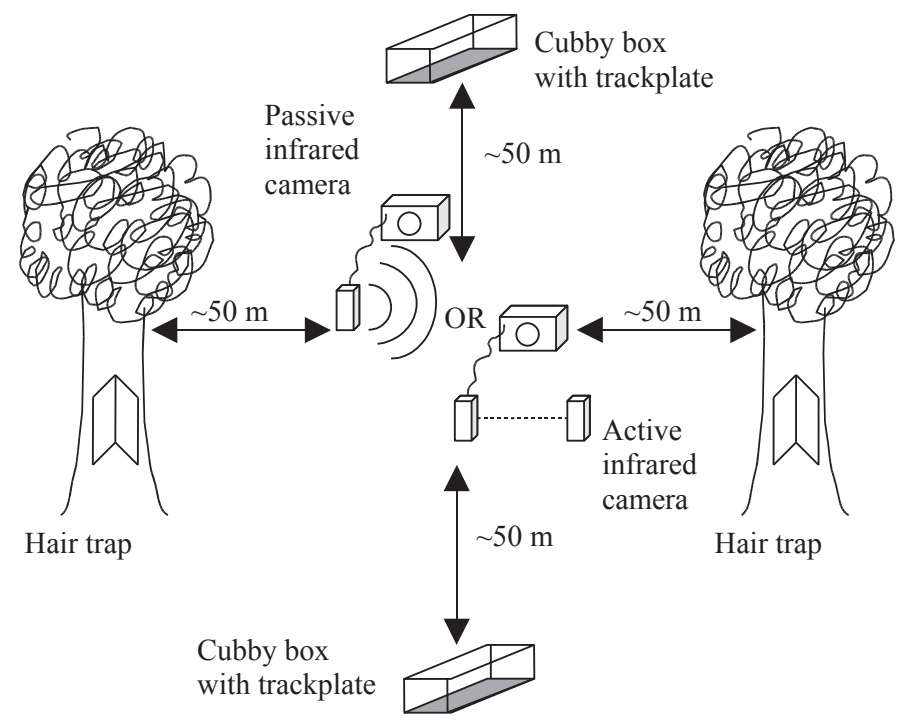

Figure 4. Design of indirect measure stations used to detect mammals in the 2004 mammal inventory. (m, meters)

\section{Indirect Measure Sampling}

We arranged IM stations in a "+"-shaped array, with a camera and infrared monitor (transmitter, receiver) at the center, and two hair traps and two cubby boxes arranged $50 \mathrm{~m}$ from the camera so that the cubby boxes and hair traps were located opposite one another (fig. 4). We randomly placed IM equipment relative to the major cardinal directions $(\mathrm{N}-\mathrm{S} / \mathrm{E}-\mathrm{W})$. We arranged some IM arrays along the four ordinal directions (NE-SW/SE-NW) to keep equipment within the park boundary and, as much as possible, to keep equipment within the selected stratum type. We set up IM stations at the beginning of each sampling session and left them operational for 2 weeks. We checked equipment every 2 to 3 days, though longer periods between checks did occur as result of logistics or weather. As necessary, we applied fresh bait and scent lure each time we visited a station. We developed detailed protocols for checking equipment (app. D).

\section{Remote Cameras}

We used either Trailmaster® active (TM 1500 or 1550) or passive (TM 550) infrared monitors with cameras (Goodson $\&$ Associates, Inc., Lenexa, Kan.). Active units have three parts: an infrared transmitter that transmits a narrow infrared beam, a receiver, and a camera. Motion is detected when an animal breaks the narrow infrared beam. Passive units have two parts: a transmitter/receiver that emits a wide infrared beam and receives the reflected signal, and a camera. Motion or change in the ambient temperature is detected over a wide cone-shaped area in the same way that a motion-sensitive light responds. In both types of systems, the camera is connected to the receiver unit with wires and triggered according to user-specified controls. A 5-minute delay was used to reduce the occurrence of multiple photographs of the same animal. Furthermore, we set cameras to take photos only between dusk and dawn to limit photos of non-target species (for example, birds).

We set cameras on level ground or, if systems were mounted on sloped ground, we aimed the cameras perpendicular to the slope. Active units were very sensitive to problems with alignment of the transmitter and receiver. Under these circumstances, we attempted to minimize elevation change along the path of the infrared beam. Improper alignment resulted in event errors and high counts (sometimes in the thousands) of false events. We cleared vegetation from the surrounding areas to reduce the number of false events caused by vegetation movement and to increase the visibility of animals. We baited cameras with chicken and commercial scent lure (Predator 500, Cronk's Outdoor Supplies, Wiscasset, Maine) applied to pieces of cotton cloth located near the bait. Appendix D contains the full protocol for setting and checking the remote cameras.

We used 24- or 36-exposure $35 \mathrm{~mm}$ color print film having an ISO of 400 or 800 speed in all cameras. We developed film as prints and obtained digital copies on CD. We referenced photos by event ID in the project database.

\section{Trackplates}

We used Zielinski's (1995) design for cubby boxes. We constructed trackplates from $20-\mathrm{x} 76-\mathrm{cm}$ aluminum valley flashing placed within the wooden frame with a single opening. We made boxes $(23 \times 23 \times 81 \mathrm{~cm})$ from exterior-grade plywood with the bottom and top pieces routed along the outside edge to hold the sides together easily. The entire structure was held together by two lengths of rope. Cubby boxes were collapsible for easy transportation. We placed boxes against a solid object (such as a tree or rock) to limit access at one end and covered the box with tree limbs to make the box rigid. We applied these techniques to obscure the box against the physical background, hoping to make the device more appealing to animals.

We covered trackplates with copier toner (Belant, 2003) on two-thirds of the side nearest the entrance to the cubby box. We cleaned trackplates with vinegar and then lightly coated them with mineral oil periodically to improve adherence of toner to the plates. We applied clear or white shelf paper $(30 \times 23 \mathrm{~cm})$ to the plate with the adhesive side up at the closed end of the box, leaving some clean plate $(\sim 7.5 \mathrm{~cm})$ for the bait, either raw chicken or canned cat food (pierced with a can opener). We also used dry cat food mixed with cod liver and anchovy oils, which was secured in a wire mesh pouch attached to the upper rear of the cubby box. We applied Predator 500 lure to cloth stapled to the outside of the box. Mammals accessing the bait transferred toner to the contact sheet, leaving a positive impression. We changed sheets during station checks if tracks were discovered. However, we did not change trackplates if only mouse-sized tracks were found, 
unless the tracks would have obscured future tracks of larger animals. We collected all contact sheets with tracks (including those with mouse tracks only) when equipment was removed. We then placed contact sheets in acetate sheet protectors in the field and archived them for later identification. Occasionally, tracks were present only on the sooted portion of the plate, leaving a negative impression. These tracks were photographed and then lifted onto clean contact sheets for archiving.

We identified tracks in the lab by measuring track width and length, palm size and shape, presence of heel pads, and general appearance (hairy, clean, pebbly, etc.) and recorded this information for front and rear tracks (when both were available). We identified tracks primarily using track descriptions and dimensions provided by Elbroch (2003), but other guide books and publications also proved helpful (Murie, 1974; Halfpenny and Biesiot, 1986; Taylor and Raphael, 1988; Rezendes, 1995; Zielinski, 1995; Loukmas and others, 2001).

\section{Hair Traps}

We used the hair sampling device developed for American Marten (Martes americana) by Mowat and Paetkau (2002). The trap consisted of two 2- x 14- x 60-cm pieces of pine screwed together lengthwise along the edges to form a roof (at approximately a 90-degree angle). The trap was screwed to trees $\sim 1.5 \mathrm{~m}$ from the ground, forming a triangular passageway through which animals could access bait as they passed through the trap. Catchmaster glue traps (AP\&G Co., Brooklyn, N.Y.) cut to 1.5- x 5-cm strips were used to capture hairs as the animal passed through the device. During the first sampling session and the beginning of the second session, we attached eight glue strips by thumbtack to the upper part of the inside of the trap at one-third the distance $(\sim 20 \mathrm{~cm})$ from each edge. During the second sampling session, we attached an additional eight glue strips to both the upper and lower outside edges of the trap, increasing our ability to sample animals that were unable or unwilling to access the interior of the trap. We attached raw chicken to the tree at the mid portion of the hair trap. We applied scent lure to pieces of cloth either inside or above the trap. We checked glue strips for hairs during each visit and replaced the glue strips if hairs were found or if the glue strips were missing or rendered ineffective by rain, insects, or other debris. We placed hair samples in bags and labeled them with the location and station identifier. We kept samples frozen for later analysis. Details of identification methods are available in Appendix E.

\section{Trapping}

We used linear arrangements of 20 small-mammal traps with 2 squirrel-sized live traps placed perpendicular to the end of the small-mammal trap lines. At some stations, one fox-sized live trap was also used (fig. 5). We arranged smallmammal trap lines along the longest axis of the selected community type (i.e., stratum) to make sure that as much of the trap line as possible was placed within the target community. We recorded the orientation of trap lines (bearing from trap 1 to 10), documented in station-description tables found in the results section for each park. We set two 90-m-long trap lines spaced $10 \mathrm{~m}$ apart with traps placed every $10 \mathrm{~m}$. We used one line of 10 Longworth-style "Little Critter" live traps (Rogers Manufacturing Co., Peachland, British Columbia) and one line of 10 Museum Special traps (Woodstream Corp., Lititz, Pa.). We set squirrel-sized 46- x 13- x 13-cm Havahart live traps (Woodstream Corp., Lititz, Pa.) $\sim 50 \mathrm{~m}$ from and perpendicular to the beginning and ends of each trap line. Initially, we set squirrel-sized traps in trees $2 \mathrm{~m}$ off the ground to target flying squirrels (Risch and Brady, 1996), but had little success using this approach. We then moved these traps to the ground to increase our chances of capturing other species. We baited small-mammal and squirrel-sized traps with a peanut butter-suet-oat mixture bound with paraffin wax that was developed for general mammal trapping (Calhoun, 1959). We used synthetic batting in each small-mammal live trap during colder months to provide nesting material. We used one large 107- x 38- x 38-cm fox-sized live trap (Tomahawk Live Trap Co., Tomahawk, Wisc.) in each stratum to document larger mammals like foxes or Fisher. We also set these traps perpendicular to and $\sim 50 \mathrm{~m}$ from one end of the small-mammal trap line opposite one of the squirrel-sized traps ( $100 \mathrm{~m}$ distant).

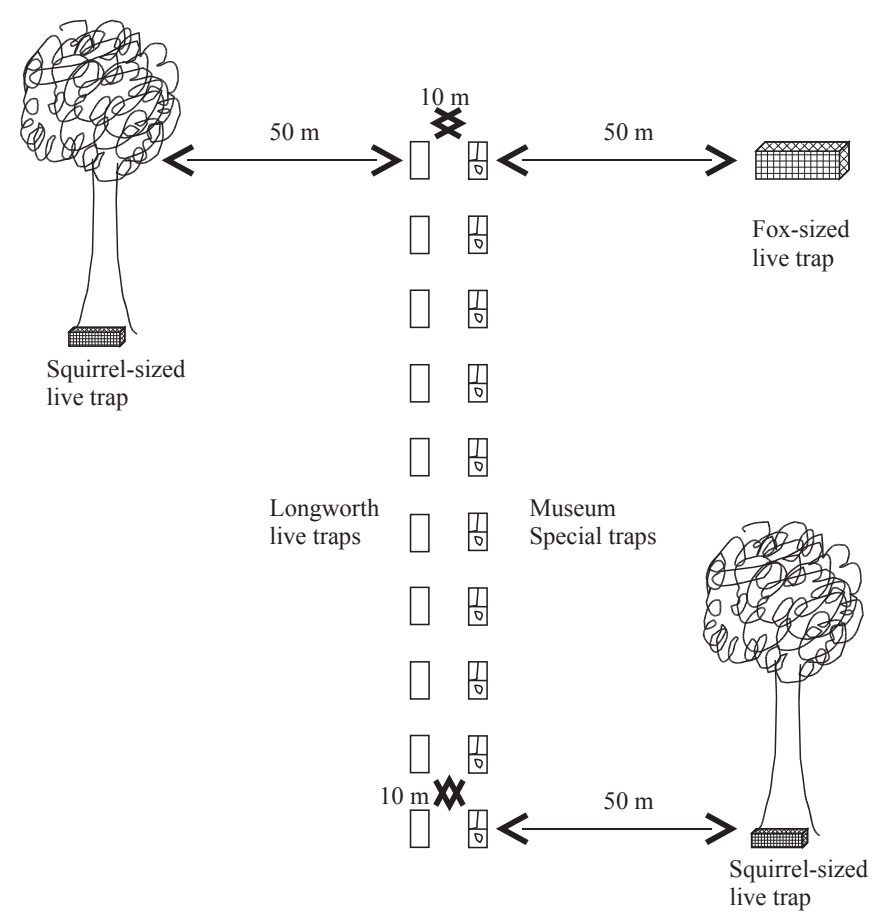

Figure 5. Small-mammal trap lines and placement of squirrelsized and fox-sized live traps used in the 2004 mammal inventory of national parks in the Northeast Temperate Network and Sagamore Hill National Historic Site. 
Table 3. Temporal sampling scheme used in the mammal inventory at parks in the Northeast Temperate Network and Sagamore Hill National Historic Site.

[NP, National Park; NHP, National Historical Park; NHS, National Historic Site; NA, not applicable]

\begin{tabular}{lcc}
\hline \multicolumn{1}{c}{ Park name } & Sampling session $\mathbf{1}$ & Sampling session 2 \\
\hline Acadia NP & $4 / 5 / 2004-4 / 19 / 2004$ & NA \\
Marsh-Billings-Rockefeller NHP & $3 / 11 / 2004-3 / 26 / 2004$ & $10 / 12 / 2004-10 / 26 / 2004$ \\
Minute Man NHP & $2 / 22 / 2004-3 / 8 / 2004$ & $7 / 19 / 2004-8 / 2 / 2004$ \\
Morristown NHP & $2 / 3 / 2004-2 / 20 / 2004$ & $6 / 21 / 2004-7 / 7 / 2004$ \\
Roosevelt-Vanderbilt NHS & $2 / 7 / 2004-2 / 23 / 2004$ & $8 / 2 / 2004-8 / 18 / 2004$ \\
Saint-Gaudens NHS & $3 / 9 / 2004-3 / 25 / 2004$ & $9 / 27 / 2004-10 / 22 / 2004$ \\
Sagamore Hill NHS & $4 / 28 / 2004-5 / 12 / 2004$ & $11 / 16 / 2004-11 / 22 / 2004$ \\
Saugus Iron Works NHS & $2 / 26 / 2004-3 / 10 / 2004$ & $9 / 20 / 2004-10 / 4 / 2004$ \\
Saratoga NHP & $3 / 29 / 2004-4 / 14 / 2004$ & $11 / 1 / 2004-11 / 22 / 2004$ \\
Weir Farm NHS & $1 / 20 / 2004-2 / 7 / 2004$ & $6 / 7 / 2004-6 / 22 / 2004$ \\
\hline
\end{tabular}

We baited each of these large traps with raw chicken and Predator 500 lure.

We did not attempt to fully document species like moles or shrews by using devices like Victor or pitfall traps that are generally regarded as the preferred methods to capture or detect these species. Moles burrow underground and require trapping devices that accommodate this trait. Also, we did not have sufficient resources to purchase the necessary equipment and devote the time required to locate and capture moles. Instead, we used incidental observations to document these mammals. We originally intended to set pitfall traps because they are the preferred device to capture shrews (Williams and Braun, 1983; Bury and Corn, 1987; Kalko and Handley, 1993), but we were unable to obtain the necessary permission from regional cultural resource program managers to use these traps. The omission of pitfalls from this study likely resulted in an under-sampling of shrews, thereby reducing species diversity estimates. We note, however, that several shrew species probably occur in each project park based on known ranges and historic documentation (Whitaker and Hamilton, 1998).

We checked and set traps daily. Initial trap setup usually required several days, resulting in a staggered sampling scheme in most project parks. When possible, we removed traps in a staggered, reverse fashion to allow traps to remain in the field the same amount of time-usually 5 trap nights. We collected physical measurements (total length, tail length, and hind foot length) and weight of small mammals caught in Longworth traps and recorded a general physical description. We recorded sex and sexual maturity when these were apparent. We marked all small mammal captures with fingernail polish on the head between the ears to identify recaptures. We collected voucher specimens when we caught individuals in Museum Special traps and froze them for later preparation as study skins. We marked larger mammals with spray paint, and took photographs. We released all captured animals as quickly as possible and at the point of capture to minimize stress.

\section{Observation Cards}

Prior to beginning field work, we developed observation cards (app. F) for reporting mammal observations. We designed these cards to be carried in the field by NPS personnel and include pertinent information to make an accurate identification (for example, observer, date, time, location). We distributed cards to park staff at the beginning of the project and we asked all personnel assisting on the project to record observations when possible. We also encouraged personnel to record observations of indirect evidence like tracks and scat. We collected cards at the end of the second sampling session and these data are included in the summary results for each park.

\section{Historical Voucher Specimen Records}

Historical species lists ( $>10$ years old) were compiled from voucher specimen data (O'Connell and others, 2004) and allow for historical comparisons of biodiversity. We did not survey for marine mammals or bats; however, we include documentation of these species in this report from the historical voucher specimens and related records.

\section{Data Collection}

We recorded data in the field using weather-resistant handheld computer devices (SPT 1700, Symbol Technologies, Inc., Oakland, Cal.) and used Pendragon Forms 3.2 software (Pendragon Forms Software Corp., Libertyville, Ill.) to create and manage forms for data collection. This software allowed multiple users to collect data and synchronize information to a single database. We created multiple data sheets consisting of equipment check logs (for example, camera check log) and identification (event) data sheets where identification of tracks or observations were recorded. We linked all events (either 
check logs or event data) to a location with a unique location identifier consistent with NPSpecies data requirements

(National Park Service, 2002). The location database describes locations and provides point coordinates (Universal Transverse Mercator, North American Datum 1983). We provided field data sheets to park staff for data collection when they checked IM stations (app. G). We added these data to the database, from which a Microsoft Access 2002 database was created and populated.

\section{Data Analyses}

We calculated naïve estimates of station occupancy and detection rates for each of the species documented by means of IM sampling. We determined which strata were occupied by each species by calculating the proportion of stations occupied. For stations with IM arrays, species detection rates were calculated by dividing the total number of individual species detections for all checks at a station by the number of checks made at that station. Mean rate of detection for each species over all stations included those stations where the species was not detected (detection rate $=0$ ).

For trapping stations, we calculated the total number of individuals captured and the rate at which they were captured.
We also calculated naïve estimates of station occupancy. We calculated the mean rate of new captures (number of new captures per night) for all trapping stations, including those with no detections. These results provide an index of occurrence for each species based on the number of days sampled but cannot be used to track changes in the target populations over time or space (Pollock and others, 2002).

Hair traps yielded a substantial number of samples. However, observation of gross morphological features for making species identifications is not an entirely objective process. Because we could not be certain of our identifications, we elected not to include these data in the analytical results sections for each park and have placed these results in appendix H. In addition, a companion research project (Talancy, 2005) on carnivores was conducted simultaneously with this survey and used an additional, more objective technique to validate species identification from hair. This technique identified species by analyzing the unique composition of peptides in hair proteins using matrix-assisted laser desorption/ionization timeof-flight mass spectrometry (MALDI-TOF) (Hollemeyer and others, 2002). Details of these results can be found in Talancy (2005) and identifications made by this method are also shown in appendix $\mathrm{H}$.
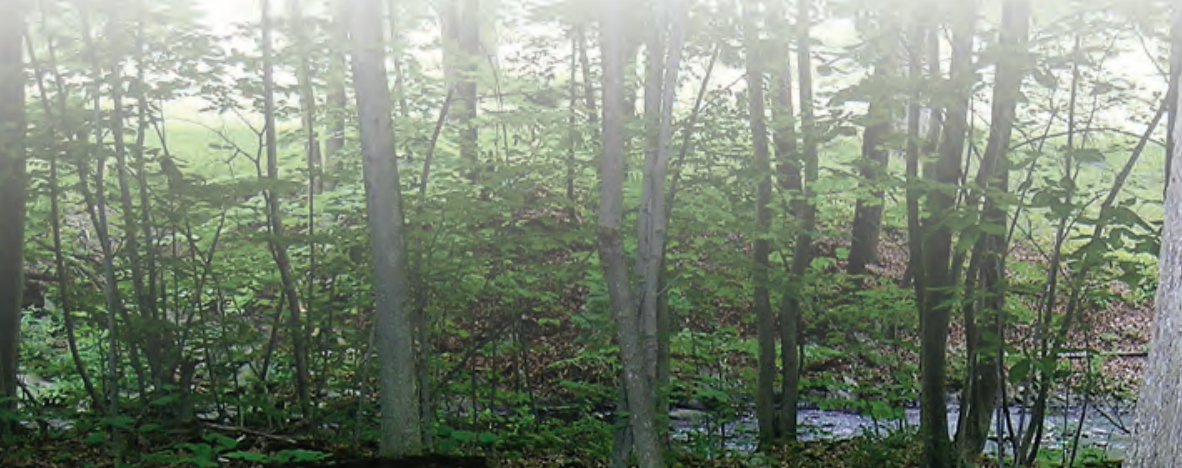


\section{Weir Farm National Historic Site (WEFA)}

\section{Background}

Weir Farm National Historic Site (WEFA) is a small suburban park dedicated to the American Impressionist work of J. Alden Weir, sculptor Mahonri Young, and painter Sperry Andrews. The park is located in south-central Connecticut between the towns of Wilton and Ridgefield. The farm is designed around Weir's home, studios, and grounds and is typical of an old New England homestead with woods, fields, a small pond, and outbuildings. The park, although small (30 ha), is bordered by several other protected areas. A 45-ha preserve owned by the Nature Conservancy - Weir Nature Preserve (The Nature Conservancy, 2005) borders WEFA on the southwest and town land borders the park on the eastern boundary. Paths through WEFA allow visitors access to the fields, forest, and pond. The majority of parkland (18 ha) is dominated by central hardwood forest typical of southern New England and 6 ha of fields (Mitchell and others, 2006). A single small pond once used for ice and recreation by the Weir family provides community type for aquatic mammals like Muskrat (Ondatra zibethica) and feeds the small stream that runs through the park.

\section{Prior Investigations}

We are not aware of any prior work on mammals that has been conducted at Weir Farm or the surrounding area.

\section{Sampling Stations}

We conducted IM sampling and trapping in January and June of 2004. We selected 16 sampling points in four community types for sampling (8 IM and 8 trap) (table 4, fig. 6).

\section{Survey Results}

We detected 16 species at WEFA: 9 during indirect measure sampling, 10 during trapping, and 7 by observation, excluding 2 individuals not identified to the species level (table 5). This is only 33 percent of the potential mammals that could occur at WEFA, excluding bats $(\mathrm{N}=49$, table 1). Measured diversity of mammals at WEFA was low, which may reflect either the small size of the park (O'Connell and others, 2004), other landscape scale factors such as fragmentation (Rosenblatt and others, 1999; Talancy, 2005) and urbanization (Crooks, 2002), and (or) an artifact of limited sampling during this study. The Domestic Cat (Felis silvestris) and Raccoon (Procyon lotor) were the most commonly detected mediumsized mammals during the winter (sampling session 1) at WEFA, although detection rates were low overall (table 6). Virginia Opossum (Didelphis virginiana) and Raccoon were the most commonly detected medium-sized mammals during sampling session 2 in the summer (table 6).

White-footed Mouse (Peromyscus leucopus) was the most commonly detected small mammal, followed by the Deer Mouse (Peromyscus maniculatus) (tables 7-8). The Northern Short-tailed Shrew (Blarina brevicauda), detected commonly in other parks, was captured only twice. Based on the natural history of this species and available community types, we expect that this species was more common than our detections would indicate. A Woodland Vole (Microtus pinetorum) was 
detected once and may be rare within WEFA (Whitaker and Hamilton, 1998).

We detected mammals more frequently in the summer (session 2) than in the winter (session 1) (table 6). We detected Coyotes (Canis latrans) only in winter, whereas the Eastern Chipmunk (Tamias striatus), Striped Skunk (Mephitis mephitis), Virginia Opossum, and Woodchuck (Marmota monax) were detected only in summer. The four species detected only in summer spend much of the winter in dens, especially during colder periods. The winter sampling period at WEFA was very cold with $>25 \mathrm{~cm}$ of snow on the ground, which may have limited movement of many species. Several species (Virginia Opossum, Raccoon, White-footed Mouse) were found in all community types, whereas Striped Skunk

Table 4. Indirect measure (IM) and trap station numbers, community type, GPS locations of the camera at IM stations and the start of the Longworth trap line, orientation of IM stations, and bearing of trap lines used in the 2004 mammal inventory at Weir Farm National Historic Site.

\begin{tabular}{|c|c|c|c|c|c|}
\hline $\begin{array}{l}\text { Station } \\
\text { number }\end{array}$ & $\begin{array}{l}\text { Station } \\
\text { type }\end{array}$ & $\begin{array}{l}\text { Community } \\
\text { type }\end{array}$ & UTM Xa & UTM Ya & $\begin{array}{c}\text { Orientation/ } \\
\text { bearing }^{\mathrm{b}}\end{array}$ \\
\hline 1 & IM & riparian & 629584 & 4568544 & $\mathrm{~N}-\mathrm{S}$ \\
\hline 2 & Trap & riparian & 629626 & 4568582 & $25^{\circ}$ \\
\hline 3 & IM & riparian & 629688 & 4568893 & E-W \\
\hline 5 & Trap & riparian & 629529 & 4568453 & $50^{\circ}$ \\
\hline 7 & Trap & wetland & 629372 & 4568332 & $156^{\circ}$ \\
\hline 9 & IM & wetland & 629187 & 4568554 & NE-SW \\
\hline 11 & Trap & wetland & 629487 & 4568576 & $200^{\circ}$ \\
\hline 13 & IM & wetland & 629416 & 4568474 & E-W \\
\hline 15 & IM & field & 629280 & 4568384 & E-W \\
\hline 19 & Trap & field & 629187 & 4568344 & $140^{\circ}$ \\
\hline 23 & Trap & field & 629283 & 4568454 & $200^{\circ}$ \\
\hline 27 & IM & field & 629326 & 4568267 & $\mathrm{~N}-\mathrm{S}$ \\
\hline 35 & IM & deciduous & 629619 & 4568751 & NE-SW ${ }^{c}$ \\
\hline 39 & Trap & deciduous & 629677 & 4569228 & $330^{\circ}$ \\
\hline 40 & IM & deciduous & 629630 & 4569281 & $\mathrm{~N}-\mathrm{S}$ \\
\hline 43 & Trap & deciduous & 629237 & 4568481 & $340^{\circ}$ \\
\hline
\end{tabular}

${ }^{a}$ Universal Transverse Mercator Zone 18; datum, North American Datum 1983; units, meters.

b The orientation of the trackplates relative to the cameras in the IM station or the bearing of the trap lines.

${ }^{\mathrm{c}}$ Due to boundary constraints, this station was arranged with the two hair traps in line with the NE trackplate instead of the camera. and Domestic Cat were detected in all but the riparian community type (table 5). Most other species were detected in at least two different community types (table 5).

There was no clear relationship between vegetation communities sampled and the number of detections of or diversity of mammals (fig. 7). This is not surprising because WEFA is dominated by deciduous forest with small patches of wetland evenly dispersed throughout the park, resulting in a more or less homogeneous landscape, with the exception of fields around the visitor center and home. Fields were the only community type in which we detected White-tailed Deer, Coyotes, and Woodland Vole, although Coyotes and deer are probably found throughout the park. Coyotes may use altered open areas such as fields for hunting and ease of travel, but also make use of wooded areas and even residential areas in suburban environments (Way and others, 2004). White-tailed Deer use a wide variety of habitats (Whitaker and Hamilton, 1998), and their tracks were evident throughout WEFA. Woodland Voles use a wide range of communities, including deciduous woodlands and fields (Whitaker and Hamilton, 1998). However, as noted, we captured only one individual of this species near the edge of a field, and this is not enough information to draw any conclusions about use of community types.

\section{Species Expected but Not Detected}

Several species of shrews (Sorex spp.) may occur in the park. Masked Shrew (S. cinereus), Smoky Shrew (S.fumeus), and Water Shrew (S. palustris) all have ranges that overlap park boundaries (Godin, 1977; Whitaker and Hamilton, 1998). The Masked Shrew makes use of a wide variety of habitats (Whitaker and Hamilton, 1998) including those found at WEFA. Many specimens have been collected in Fairfield County, and two found in the town of Wilton (Godin, 1977) indicate a very high likelihood that this species occurs on NPS land. The Smoky Shrew prefers shaded, damp woods, which occur along the inlet and outlet to Weir Pond. Specimens have been collected in Wilton and other towns in Fairfield County (Godin, 1977). Water shrews, as the name implies, are semiaquatic, and they prefer wetlands along streams, lakes, and ponds (Godin, 1977; Whitaker and Hamilton, 1998). The areas around Weir Pond and adjacent streams as well as wetlands along the western edge of the park may provide suitable habitat for this species.

We did not detect any moles at WEFA. These animals are primarily fossorial, preferring to tunnel underground for food, although the Star-nosed Mole (Condylura cristata) also makes use of wet areas such as meadows, swamps, and streams to feed (Whitaker and Hamilton, 1998). They are not routinely captured in small-mammal traps, and we did not expect to detect them in this study unless we observed them directly or found evidence of the mounded tunnels they create in the soil. We expect that both Eastern (Scalopus aquaticus) and Starnosed Moles occur at WEFA because voucher specimens have been recorded for both species (table 9). 


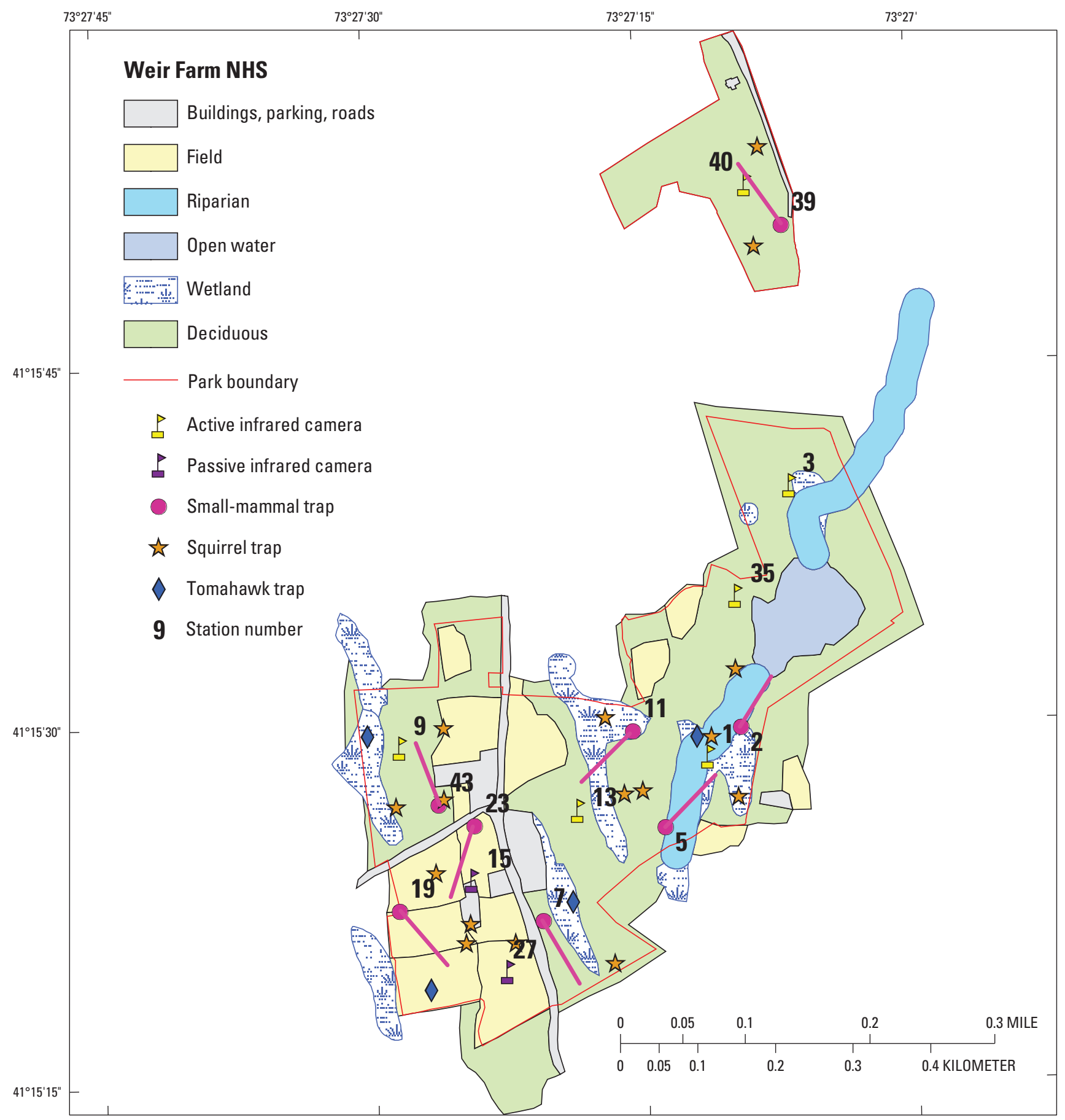

Figure 6. Locations of remote cameras and other detection devices, trapping equipment, and orientation of small-mammal trap lines used in the 2004 mammal inventory at Weir Farm National Historic Site. (Two trackplates and two hair traps were arranged about 50 meters from each camera location. Two small-mammal trap lines (10 Longworth and 10 Museum special traps spaced 10 meters between traps) were set parallel to each other 10 meters apart and oriented as shown (pink lines). Two squirrel-sized live traps and, at some stations, a single fox-sized live trap completed each trapping station. Station numbers are provided for sampling arrays.) 
Table 5. Community type associations of mammals detected at Weir Farm National Historic Site by indirect measure sampling, trapping, and observation.

[Community type associations are based on vegetation community descriptions of each sampling location. C, camera; TP, trackplate; TR, trapping; X, species observed for which we have records; -, not detected]

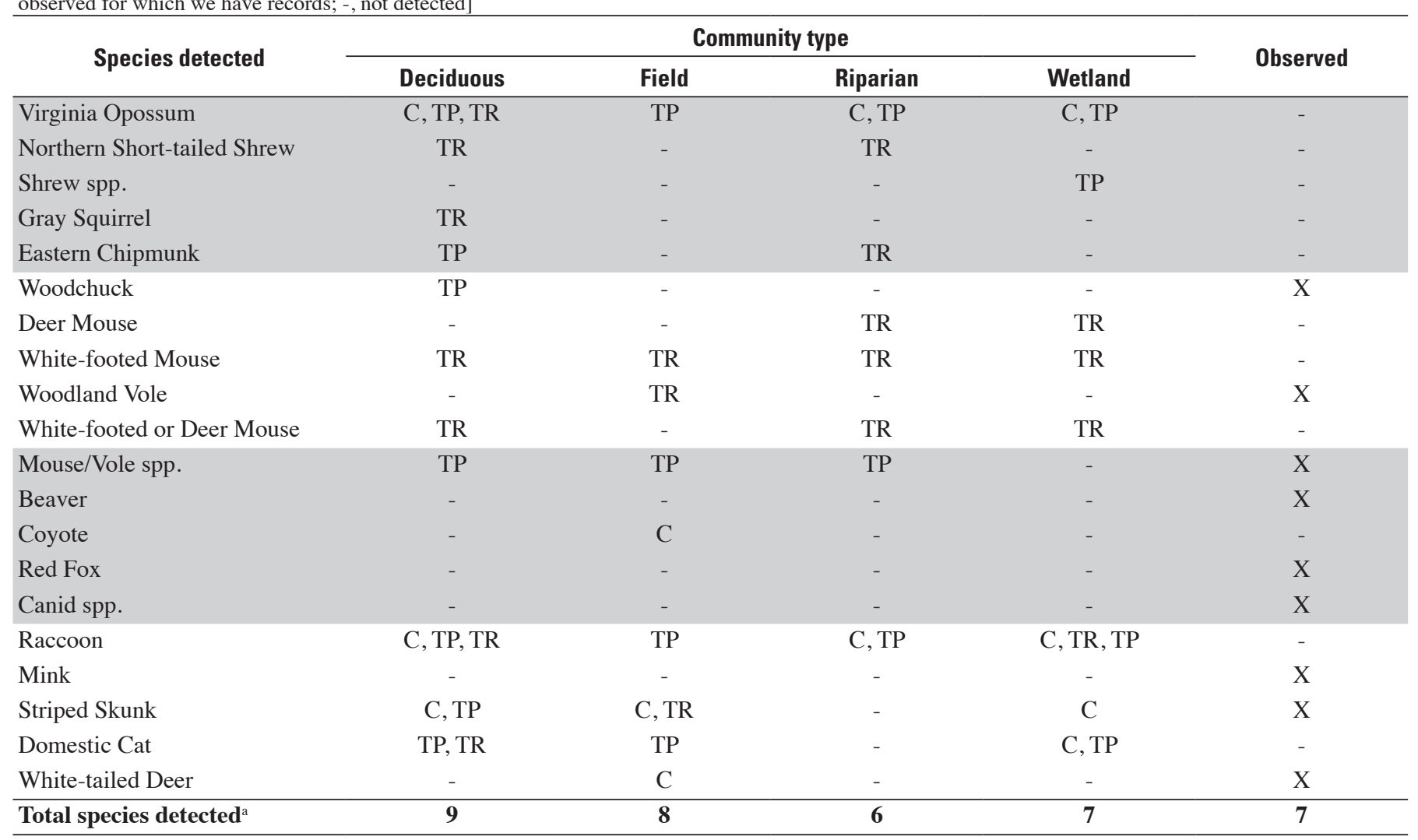

${ }^{a}$ Totals exclude generic counts unless no other species in that group were detected (for example, Shrew spp. would be counted if no other specific shrew was detected).

Table 6. Mammal species detection rates and site occupancy at eight indirect measure stations at Weir Farm National Historic Site during two sampling sessions in 2004.

$[-$, species not detected $]$

\begin{tabular}{|c|c|c|c|c|}
\hline \multirow{2}{*}{ Species detected } & \multicolumn{2}{|c|}{$\begin{array}{c}\text { Session } 1 \\
(1 / 20 / 2004-2 / 7 / 2004) \\
\end{array}$} & \multicolumn{2}{|c|}{$\begin{array}{c}\text { Session } 2 \\
(6 / 7 / 2004-6 / 22 / 2004) \\
\end{array}$} \\
\hline & $\begin{array}{c}\text { Number of stations } \\
\text { occupied (proportion) }\end{array}$ & Mean detection rate (SE) & $\begin{array}{c}\text { Number of stations } \\
\text { occupied (proportion) }\end{array}$ & Mean detection rate (SE) ${ }^{\mathrm{a}}$ \\
\hline Virginia Opossum & - & - & $7(0.88)$ & $2.69(0.70)$ \\
\hline Shrew spp. & $1(0.12)$ & $0.02(0.02)$ & - & - \\
\hline Eastern Chipmunk & - & - & $1(0.12)$ & $0.02(0.02)$ \\
\hline Mouse/Vole/Shrew spp. & $1(0.12)$ & $0.04(0.04)$ & - & - \\
\hline Coyote & $1(0.12)$ & $0.02(0.02)$ & - & - \\
\hline Raccoon & $3(0.38)$ & $0.11(0.06)$ & $8(1.00)$ & $1.35(0.27)$ \\
\hline Striped Skunk & - & - & $5(0.62)$ & $0.15(0.06)$ \\
\hline
\end{tabular}


Table 7. Mammal capture rates and site occupancy for eight trapping stations (four with fox-sized live traps) at Weir Farm National Historic Site during sampling session 1 (1/20/2004-2/7/2004).

\begin{tabular}{lccr}
\hline \multicolumn{1}{c}{ Species detected } & $\begin{array}{c}\text { Number of new } \\
\text { captures }\end{array}$ & $\begin{array}{c}\text { Number of stations occupied } \\
\text { (proportion) }\end{array}$ & $\begin{array}{c}\text { Mean rate of new individuals } \\
\text { captured (SE) }\end{array}$ \\
\hline Gray Squirrel & 1 & $1(0.12)$ & $0.02(0.02)$ \\
White-footed Mouse & 1 & $1(0.12)$ & $0.03(0.03)$ \\
Deer or White-footed Mouse & 2 & $1(0.12)$ & $0.05(0.05)$ \\
Domestic Cat & 1 & $1(0.25)$ & $0.05(0.05)$ \\
\hline
\end{tabular}

${ }^{a}$ Small-mammal and squirrel-sized live traps were placed at all 8 stations whereas fox-sized live traps were set at only 4 ; therefore, the number of stations at which medium-sized mammals (Domestic Cat) could be captured was reduced to 4 for individual species for each night of sampling.

${ }^{\mathrm{b}}$ Rates were calculated for each station by dividing the total number of new individuals captured (per species) by the number of nights that traps were operational. SE, standard error of the mean.

Table 8. Mammal capture rates and site occupancy for eight trapping stations (four with fox-sized live traps) at Weir Farm National Historic Site during sampling session 2 (6/7/2004-6/22/2004).

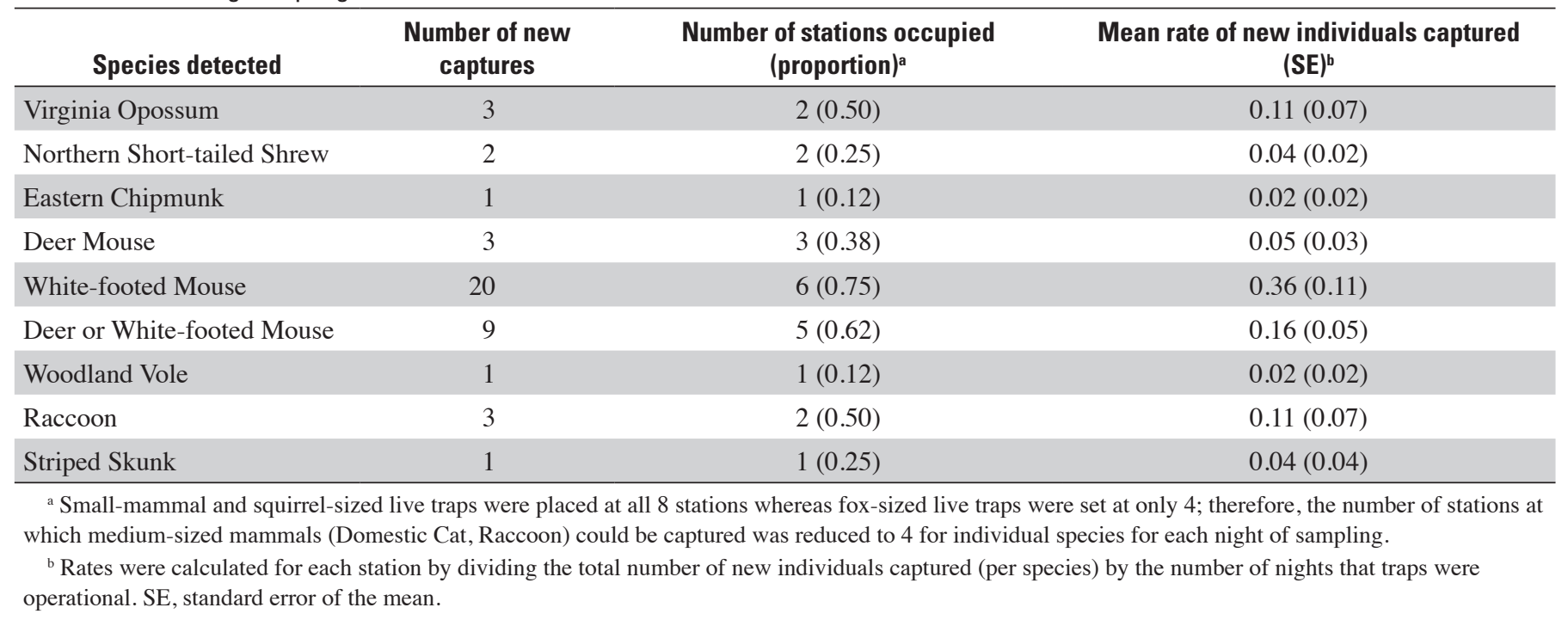

We did not capture Meadow Voles despite the availability of seemingly adequate habitat. Populations of this species are cyclical (Ostfeld and Canham, 1995, and references therein), and we may have sampled during a low population level. The occurrence of this species within the county has been documented previously (table 9) and indicates that it may occur in the fields around the Weir studio and visitor center.

The Southern Flying Squirrel (Glaucomys volans) can occur in a variety of forest types but their range is limited by mast-producing species such as oaks and hickories (Weigl, 1978; Whitaker and Hamilton, 1998) and they are known to require a mature forest component (Taulman and Smith, 2004; Holloway and Malcolm, 2007). Although we did not detect this species during this inventory, a voucher specimen is available from Fairfield County (table 9), and because of the amount of suitable forested land within WEFA, and on adjacent Nature Conservancy and undeveloped town properties, we believe that this squirrel species does occur locally.
We did not detect Gray Fox (Urocyon cinereoargenteus), but believe that this canid can occur in WEFA and the surrounding area. This predator is native to New England (Godin, 1977) and was detected in other parks in this inventory in southern New England and New York. We found voucher specimens from Fairfield County (table 9), which indicates that this species occurred historically in the area. However, the increasing numbers of Coyotes in the region may have displaced this species as a result of competitive exclusion (Fedriani and others, 2000).

We did not detect the Long-tailed Weasel (Mustela frenata), despite records of occurrence in the county (table 9) and widespread distribution across Eastern North America. Voles are a major prey source for this weasel (Whitaker and Hamilton, 1998), and a low vole population may have suppressed the population of this predator. Furthermore, Long-tailed Weasels range widely over as much as 10 to 20 ha (Whitaker and Hamilton, 1998), indicating that few individuals are likely 


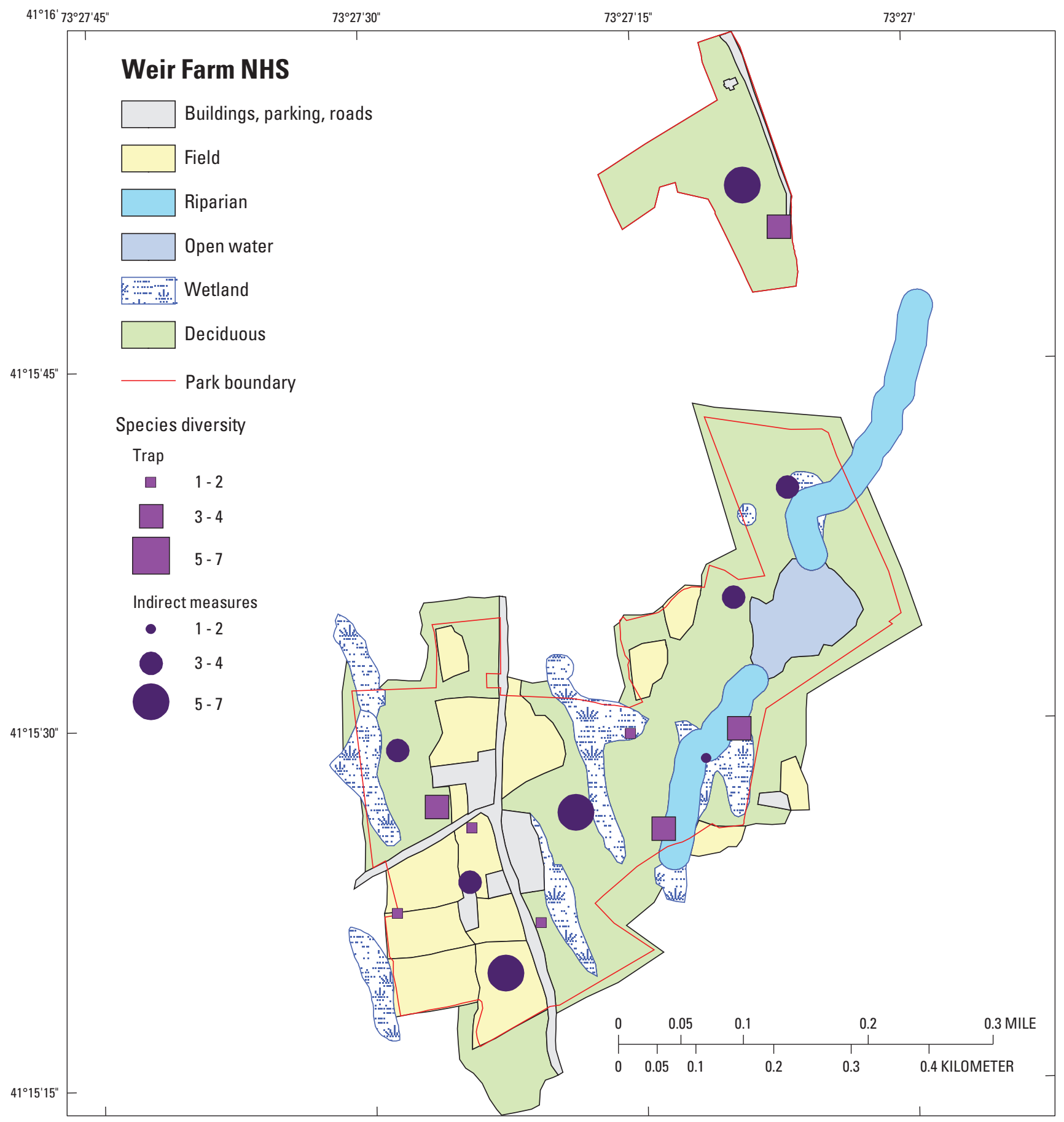

Figure 7. Species diversity results for trapping and indirect measure sampling stations during the 2004 mammal inventory at Weir Farm National Historic Site. 
to occur within park boundaries as a result of the WEFA's small size. Short-tailed Weasel (Ermine, M. erminea) also may occur here, but its presence is much less likely because this species is at the southern edge of its range (Whitaker and Hamilton, 1998).

\section{Endangered and Threatened Species}

We did not detect any species that were state or federally threatened or endangered, and in fact, all species detected are locally or regionally abundant. The State of Connecticut lists only the Least Shrew (Cryptotis parva) as endangered, with no mammals listed as threatened (Connecticut Department of Environmental Protection, 2004a). The Least Shrew is thought to occur in southwestern Connecticut; but few specimens have been documented; the last was reported in 1989 in Middlesex County. Godin (1977) noted a specimen collected in Fairfield County from the town of Darien. The likelihood that the Least Shrew occurs in the park is low.

The New England Cottontail (Sylvilagus transitionalis) was not detected in this study, and the State of Connecticut has considered listing this species as threatened or endangered (Connecticut Department of Environmental Protection, 2004b). The Federal government was petitioned to list the species as federally threatened or endangered, and the listing status was recently updated to level two for final determination on the proposed listing (CFR 50-17; 06:53756-53835). The species prefers dense, shrubby habitat (Whitaker and Hamilton, 1998; Litvaitis and others, 2003), including that formed by Mountain Laurel (Kalmia latifolia) (Connecticut Department of Environmental Protection, 2004b). Some small, dense stands of Mountain Laurel occur in the park, but these areas may not be large enough to accommodate this species, which has a mean home range size of 3.7 hectares (Connecticut Department of Environmental Protection, 2004b). The historic range of the New England Cottontail included all of Connecticut (Litvaitis and others, 2003), and recent work has documented the occurrence of this species in the southwestern part of the state, including the towns of Newtown and Sherman in Fairfield County (Kilpatrick, 2005). The New England Cottontail may occur in the park, but it is difficult to distinguish this species from the physically similar Eastern Cottontail (S. floridanus). Correct species identification requires DNA analysis from tissue or fecal material or examination of skull structure (U.S. Fish and Wildlife Service, 2005b).

Table 9. Number of mammal specimens in museum collections and their proximity to Weir Farm National Historic Site.

[Proximity-to-park codes: 1, collected within park boundaries; 2, collected in the town (Wilton and Ridgefield, Conn.) the park is located in; 3, collected in the county (Fairfield) the park is located in. Institutions: AMNH, American Museum of Natural History; CUMV, Cornell University Museum of Vertebrates; FMNH, Field Museum of Natural History; UMMZ, University of Michigan Museum of Zoology; YPM, Yale University Peabody Museum of Natural History. ,- no specimens]

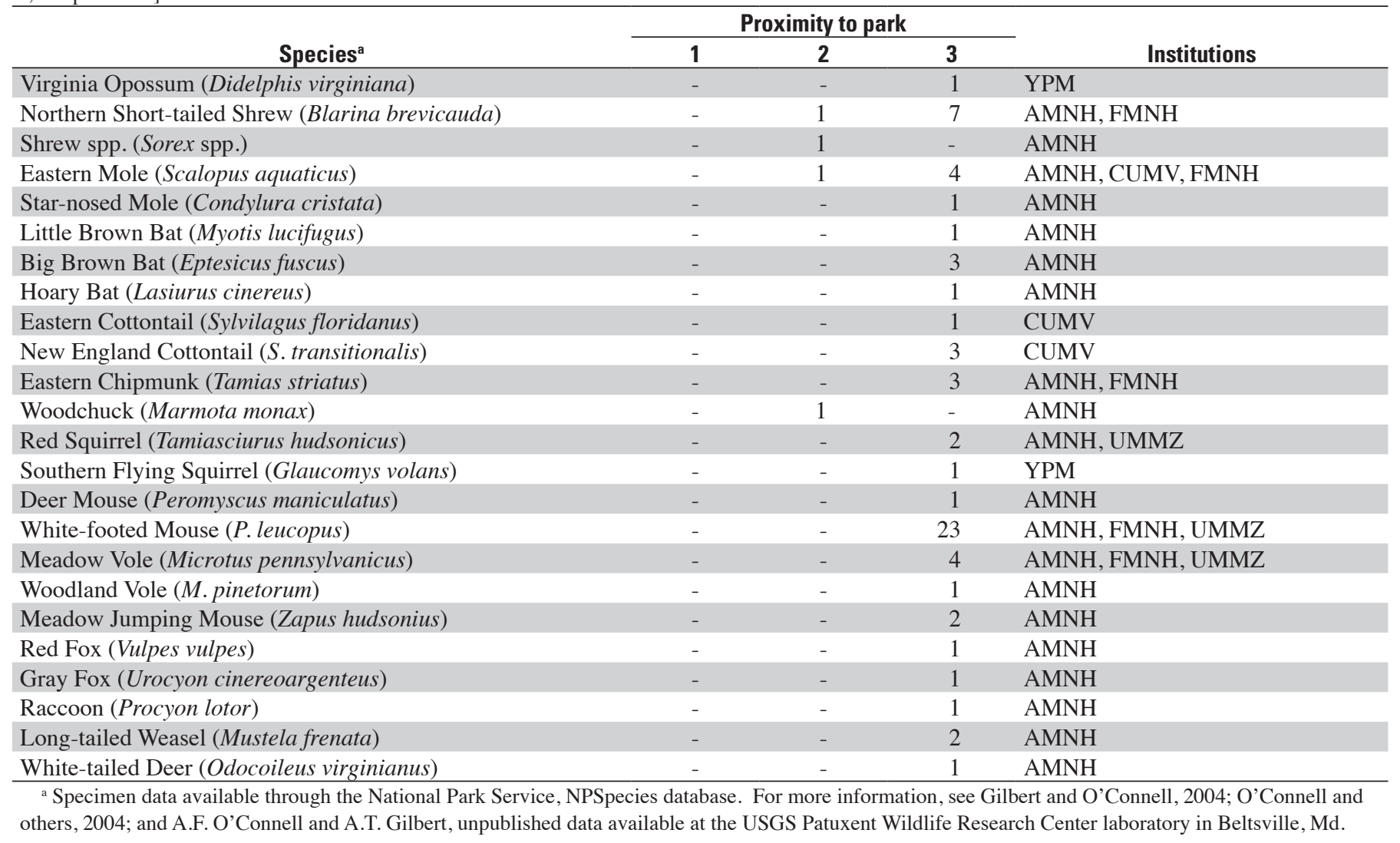




\section{Morristown National Historical Park (MORR)}

\section{Background}

Morristown National Historical Park (MORR) is the site of an important winter encampment for the Continental Army under the leadership of George Washington during the Revolutionary War. The park is within the suburban area surrounding the city of Morristown, a populous urban area in north-central New Jersey. The park is 691 ha in size and bordered by additional open space. The Scherman-Hoffman Sanctuary of the New Jersey Audubon Society (75 ha) lies adjacent to the southeast portion of the New Jersey Brigade Encampment Area, and Lewis Morris County Park (318 ha) is adjacent to the western border of the Jockey Hollow Encampment Area. Together these areas comprise a substantial amount of protected land that provide for a variety of land uses including natural and historic preservation, education, picnicking, and other recreational uses. MORR is mostly forested in the central hardwood type but also contains a large amount of old-field successional community type (Mitchell and others, 2006). Very few wetlands occur in the park, and most of these are small streams. The Passaic River has its source near the New Jersey Brigade unit and is an important natural resource for the park and the adjacent Scherman-Hoffman Sanctuary.

\section{Prior Investigations}

Several studies of White-tailed Deer (Odocoileus virginianus) have been conducted at MORR. The first study of deer ecology and condition was in the mid 1980s (Christie and Sayre, 1989), and results showed that deer remained mostly within park boundaries and that mortality was due primarily to vehicle collision or malnutrition. In addition, this study reported that deer adversely affect both structure and composition of vegetation at MORR. A feasibility study of deer fertility control was conducted at MORR in 1997, in which accessibility of deer to treatment and the ability to monitor success of the control program were tested (Underwood, 1997). Deer were found to be only moderately accessible for remote delivery of contraceptives and the method was not recommended as a future management option. A follow-up study was proposed by Porter and Underwood (1997) to test bait stations as an alternative method for attracting deer to administer fertility treatments but was never carried out.

More recently, interactions between deer and plant growth have been evaluated at MORR. The New Jersey Division of Fish and Wildlife conducted a study of the effects of varying deer density on vegetation diversity and density (Robert Masson, National Park Service, oral commun., 2005) and Ruhren and Handel (2003) studied forest herb restoration from 1997 to 2000 in the Jockey Hollow section of the park. The Ruhren and Handel study indicated that plant survival was low outside of exclosures and that surviving plants did not flower. They concluded that plant restoration was not feasible with this amount of herbivory unless protective fencing was used.

The diversity and abundance of bats was studied in the summer of 2002 (Pipliski, 2002). Four species were captured: Big Brown Bat (Eptesicus fuscus), Red Bat (Lasiurus borealis), Little Brown Bat (Myotis lucifugus), and Northern Longeared Bat (M. septentrionalis), the last being the most commonly captured species.

\section{Sampling Stations}

Indirect measure sampling was conducted in February and both IM sampling and trapping were conducted in June of 2004. We selected 22 sampling points (11 IM and 11 trap) 
in six community types (table 10; figures 8-9). Only two grid cells were assigned to the wetland stratum, resulting in only 22 sampling points (expected 24); both sampling points were used, one for trapping and the other for IM. A seventh community type (mature deciduous trees with Barberry (Berberis thunbergii)) was discovered once we initiated field work. Several areas of conifer at MORR were incorrectly classified prior to field work. We maintained the original suite of sampling points in the original conifer strata, but described these stations according to their true community type (mature deciduous with Barberry) to determine community type associations after work was complete.

\section{Survey Results}

Seventeen species were detected at MORR: 13 during indirect measure sampling, 7 during trapping, and 3 by observation. This is 33 percent of the potential number of mammal species that could occur in the park, excluding bats $(\mathrm{N}=51$, table 1). Raccoon (Procyon lotor) was by far the most fre- quently detected and widely distributed medium-sized mammal species during both winter and summer (tables 11-12).

Red Fox (Vulpes vulpes) was detected frequently at more than half of all stations in the winter and with moderate frequency in the summer. Southern Flying Squirrel (Glaucomys volans) and the Domestic Cat (Felis silvestris) were the next most frequently detected mammals during the winter. The Virginia Opossum (Didelphis virginiana) also was detected frequently during the summer. White-footed Mouse (Peromyscus leucopus) was the most commonly detected small mammal, and many Eastern Chipmunks (Tamias striatus) and Meadow Voles (Microtus pennsylvanicus) were detected (table 13).

We detected a single weasel (Mustela spp.) by camera. The individual could be either a Long-tailed Weasel $(M$. frenata), whose range includes nearly all of eastern North America and which can be found in a variety of habitats, or an Ermine (M. erminea), which is also distributed throughout North America but is confined to more northerly latitudes, reaching its southern limit in northern New Jersey (Whitaker and Hamilton, 1998; Svendsen, 2003). The Long-tailed Weasel is listed as a rare mammal at the Scherman-Hoffman Wildlife

Table 10. Indirect measure (IM) and trap station numbers, community type, GPS locations of the camera at IM stations and beginning of the Longworth trap lines, orientation of IM stations, and bearing of trap lines at Morristown National Historical Park.

\begin{tabular}{|c|c|c|c|c|c|}
\hline Station number & Station type & Community type & UTM Xa & UTM Ya & Orientation/bearing ${ }^{\mathrm{b}}$ \\
\hline 1 & IM & riparian & 539945 & 4513142 & $\mathrm{~N}-\mathrm{S}$ \\
\hline 5 & IM & riparian & 539162 & 4512967 & E-W \\
\hline 13 & Trap & riparian & 539385 & 4513289 & $30^{\circ}$ \\
\hline 17 & IM & mature deciduous w/ Barberry & 539639 & 4514365 & $\mathrm{~N}-\mathrm{S}$ \\
\hline 19 & IM & field & 539222 & 4512790 & NW-SE \\
\hline 23 & Trap & field & 540497 & 4512922 & $20^{\circ}$ \\
\hline 27 & Trap & field & 538466 & 4512801 & $30^{\circ}$ \\
\hline 31 & IM & field & 538412 & 4511253 & $\mathrm{~N}-\mathrm{S}$ \\
\hline 47 & $\mathrm{IM}$ & successional broadleaf & 538751 & 4513036 & $\mathrm{~N}-\mathrm{S}$ \\
\hline 51 & IM & broadleaf mature & 538819 & 4513395 & E-W \\
\hline 55 & Trap & broadleaf mature & 539640 & 4513463 & $140^{\circ}$ \\
\hline 59 & Trap & broadleaf mature & 540146 & 4512623 & $20^{\circ}$ \\
\hline 63 & $\mathrm{IM}$ & broadleaf mature & 540820 & 4513482 & E-W \\
\hline 67 & Trap & conifer & 540065 & 4512539 & $160^{\circ}$ \\
\hline 69 & IM & mature deciduous w/ Barberry & 538079 & 4510964 & $\mathrm{~N}-\mathrm{S}$ \\
\hline 70 & Trap & mature deciduous w/ Barberry & 538297 & 4511154 & $180^{\circ}$ \\
\hline 71 & $\mathrm{IM}$ & mature deciduous w/ Barberry & 538211 & 4510969 & $\mathrm{~N}-\mathrm{S}$ \\
\hline
\end{tabular}

a Universal Transverse Mercator Zone 18; datum, North American Datum 1983; units, meters.

b The orientation of the trackplates relative to the cameras in the IM station or the bearing of the trap lines. 


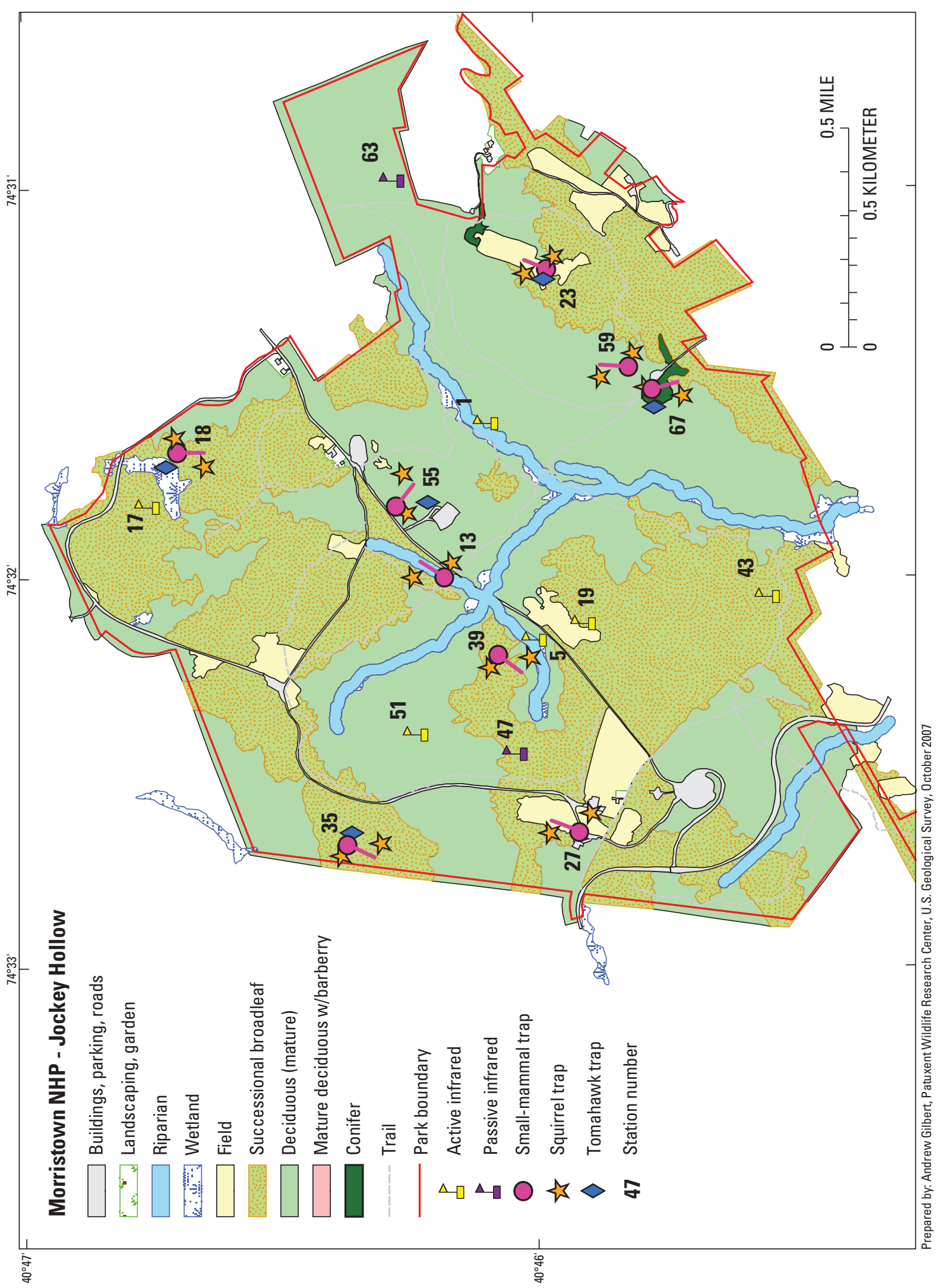

+ त

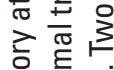

进 衤

音旁

토을

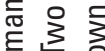

客

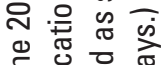

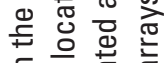

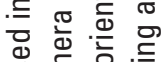

ब

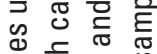

号它志

웡 $\stackrel{0}{\circ} \frac{0}{\pi}$

ॠ

要

E

톨 을 은

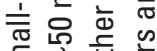

का

论 离

듀 đ

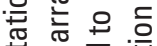

蒙迹恶

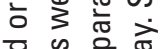

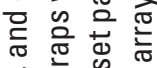

㝴志递

统

흘 竞它

잉

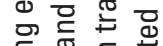

言西

त

$=\frac{1}{2}$ 造

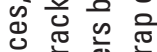

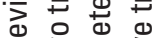

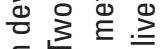

드능응

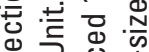

过

응 की

호후응

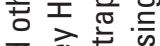

可产竞

is

政 1 के

离竞要

ชั ฮ ฮ

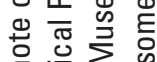

텅ㅎㅎㅇ은

능 娄흘

क六 ส

듬 তٓ

을 은 중

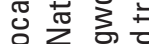

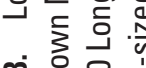

$\infty$ 엥응

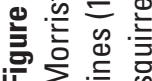



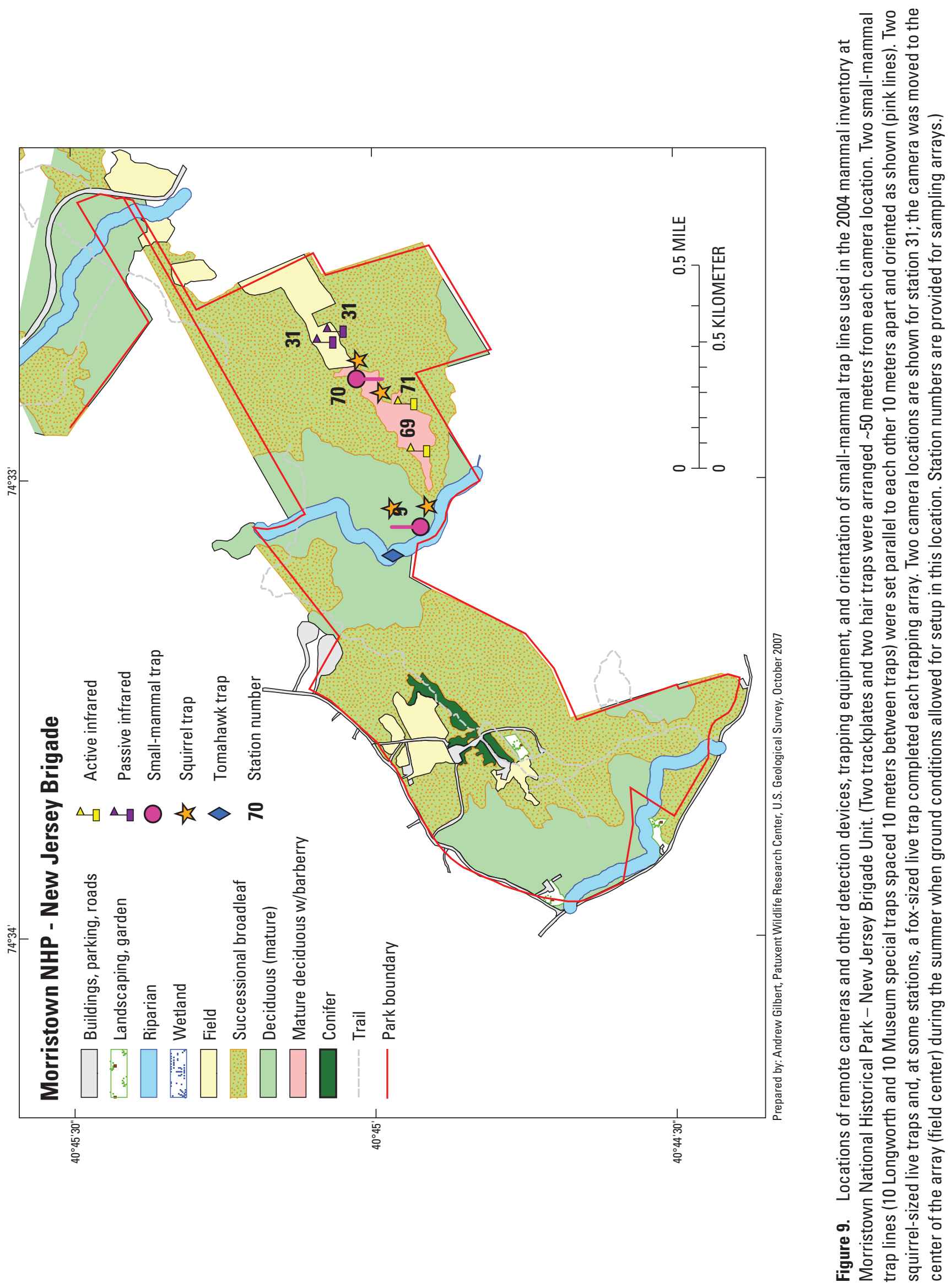


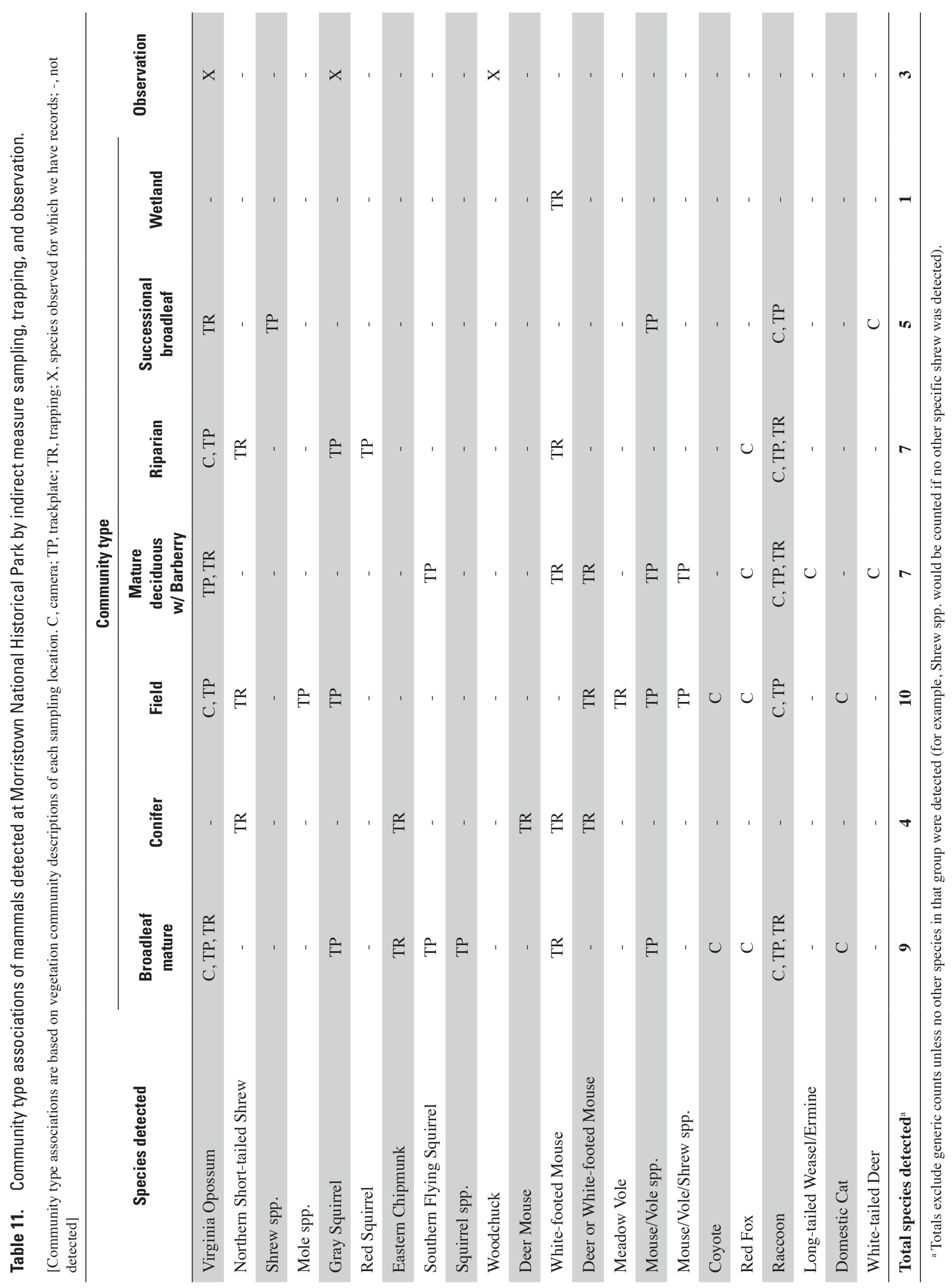


Table 12. Mammal species detection rates and site occupancy at 11 indirect measure stations at Morristown National Historical Park during two sampling sessions in 2004.

$[-$, species not detected]

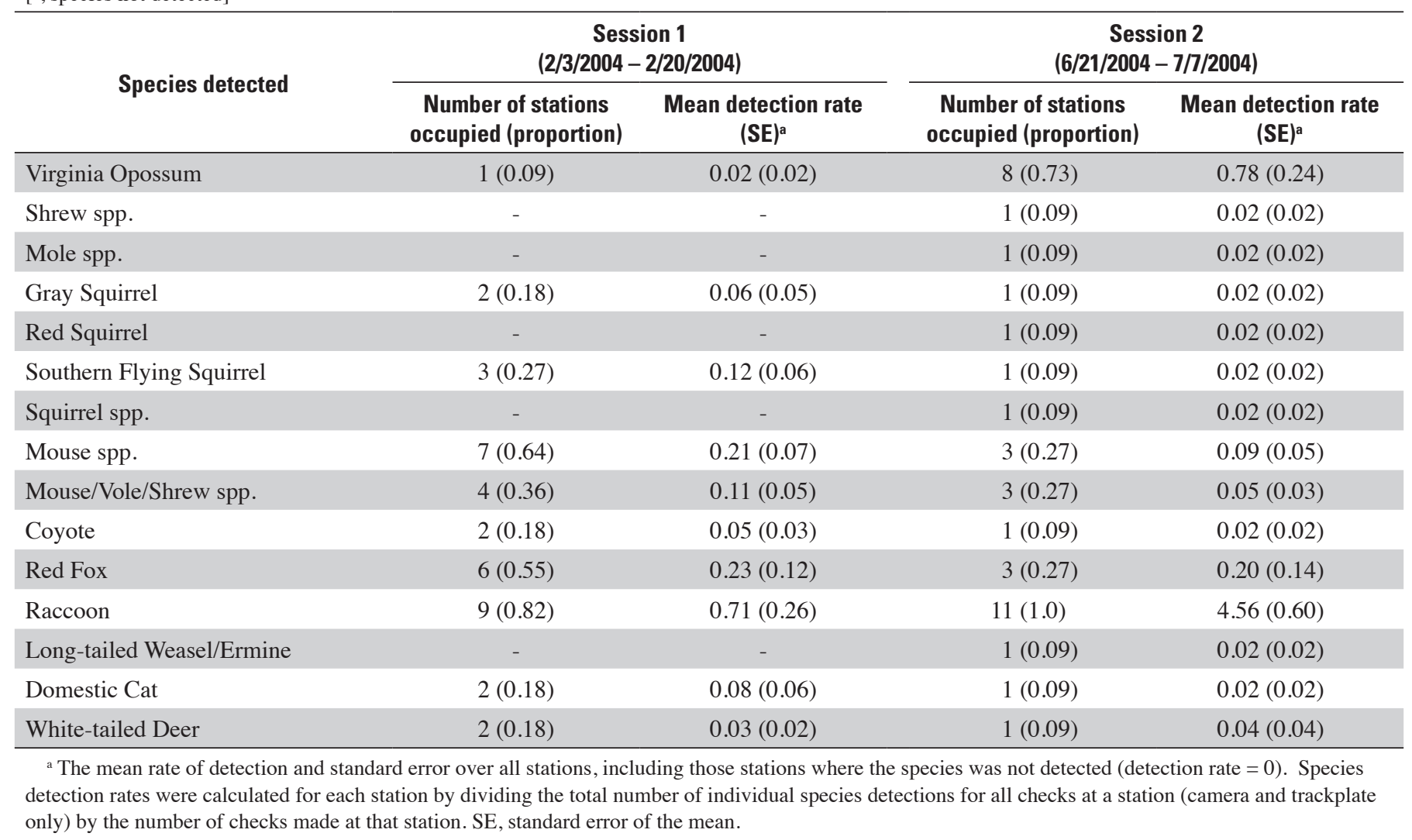

Table 13. Mammal capture rates and site occupancy for 11 trapping stations ( 6 with fox-sized live traps) at Morristown National Historical Park during sampling session 2 (6/21/2004 - 7/7/2004).

\begin{tabular}{|c|c|c|c|}
\hline Species detected & $\begin{array}{c}\text { Number of } \\
\text { new captures }\end{array}$ & $\begin{array}{c}\text { Number of stations occupied } \\
\text { (proportion) }{ }^{\mathrm{a}}\end{array}$ & $\begin{array}{c}\text { Mean rate of new individuals } \\
\text { captured (SE) }\end{array}$ \\
\hline Virginia Opossum & 3 & $3(0.50)$ & $0.08(0.04)$ \\
\hline Eastern Chipmunk & 7 & $1(0.09)$ & $0.11(0.11)$ \\
\hline Deer Mouse & 1 & $1(0.09)$ & $0.02(0.02)$ \\
\hline White-footed Mouse & 23 & $6(0.55)$ & $0.35(0.17)$ \\
\hline Meadow Vole & 7 & $2(0.18)$ & $0.11(0.08)$ \\
\hline Raccoon & 4 & $3(0.50)$ & $0.11(0.06)$ \\
\hline
\end{tabular}


Sanctuary (New Jersey Audubon Society, 2003b), which abuts the New Jersey Brigade Unit and is near the location where we made this observation (station 71). However, we do not know how the New Jersey Audubon Society determined the status of the Long-tailed Weasel on their property and our photograph did not allow an accurate assessment of physical size or characteristics. Where Ermine and Long-tailed Weasels are sympatric, they can be distinguished by size (Svendsen, 2003).

We found seasonal differences in species diversity as well as detection rates for individual species at MORR. Southern Flying Squirrel, Gray Squirrel (Sciurus carolinensis), Domestic Cat, and Coyote (Canis latrans) were detected more often in winter. Only the aforementioned weasel, Red Squirrel (Tamiasciurus hudsonicus), Shrews, and Moles were not detected in the winter. However, these small mammals were not trapped in the winter and moles were not trapped at all.

Field and broadleaf mature community types were the most diverse and wetland and conifer community types least diverse at MORR (table 11). We had relatively few IM arrays or traps in wetland and conifer communities, and given their small size and overall proportion within the park, we did not expect species typically associated with these communities to be locally abundant. We were, however, surprised by the diversity of species in mature deciduous forest with Barberry understory (see figures 10-11). Barberry is a highly invasive non-native plant that tends to dominate the landscape with dense growth. We suggest that these conditions may attract a variety of mammalian species by providing both cover and food.

\section{Species Expected but Not Detected}

The Masked Shrew and Smoky Shrew have been collected close to MORR (table 14), and the Long-tailed Shrew (Sorex dispar) and Water Shrew (S. palustris) also occur in New Jersey (Whitaker and Hamilton, 1998), but their presence has not been detected in the park or surrounding communities.

Gray Fox (Urocyon cinereoargenteus) was not detected at MORR, but may occur there. This predator is native to New Jersey (Godin, 1977) and was detected in other project parks across southern New England and New York. The increasing presence of Coyotes may have displaced this species as a result of competitive exclusion (Fedriani and others, 2000).

Although we expected to find the Striped Skunk (Mephitis mephitis) at MORR, we failed to detect this species. The range of the Striped Skunk includes most of the eastern United States and all of New Jersey, and it can occur in a diversity of habitats including agricultural fields, forest edges, ravines, drainage ditches, and vacant buildings (Godin, 1977; Whitaker and Hamilton, 1998). Although their range is widespread, they prefer areas where sources of food, cover, and water are plentiful and they can be noticeably absent from some suburban areas. The Scherman-Hoffman Sanctuary lists this carnivore as rare in the area (New Jersey Audubon Society, 2003b).

Mink (Mustela vison) were not detected in this study but this mustelid has been reported along the Passaic River (New
Jersey Audubon Society, 2003b). Mink are typically associated with water, preferring to inhabit streams, rivers, lakes, and marshes. However, they can be found at some distance from water when food or water is limited (Godin, 1977). There is no reason to believe that the Passaic River cannot currently support this species.

We did not expect to detect Black Bears (Ursus americanus) at MORR; however, this species has been reported passing through the park three to four times a year (Robert Masson, National Park Service, oral commun., 2005). Actual evidence of this species includes a single Black Bear specimen collected several miles east of the park in Harding Township in 1952 (table 14). Black Bears are now numerous in the northern part of New Jersey, and their population is increasing (New Jersey Division of Fish and Wildlife, 2005b). Although Black Bears have not been reported breeding within MORR, they have home ranges up to $39 \mathrm{~km}^{2}$ (Whitaker and Hamilton, 1998) and could move into the vicinity of the park and utilize local resources.

\section{Endangered and Threatened Species}

We did not detect any species that were listed as state or federally threatened or endangered. The State of New Jersey lists the Bobcat (Lynx rufus), Indiana Bat (Myotis sodalis), and Allegheny Woodrat (Neotoma magister) as endangered within the State (New Jersey Division of Fish and Wildlife, 2005e).

Bobcats were reintroduced to northern New Jersey during 1978-84 and are thought to be well established despite their status (New Jersey Division of Fish and Wildlife, 2005c, e). Surveys in 1995 confirmed their presence in counties in the northern part of the state including Morris County (New Jersey Division of Fish and Wildlife, 2005c). Bobcats preferentially use mixed forest types throughout their range, but can also be found in deciduous forest. They require rocky ledges, bogs, or swamps for resting and activity areas (Whitaker

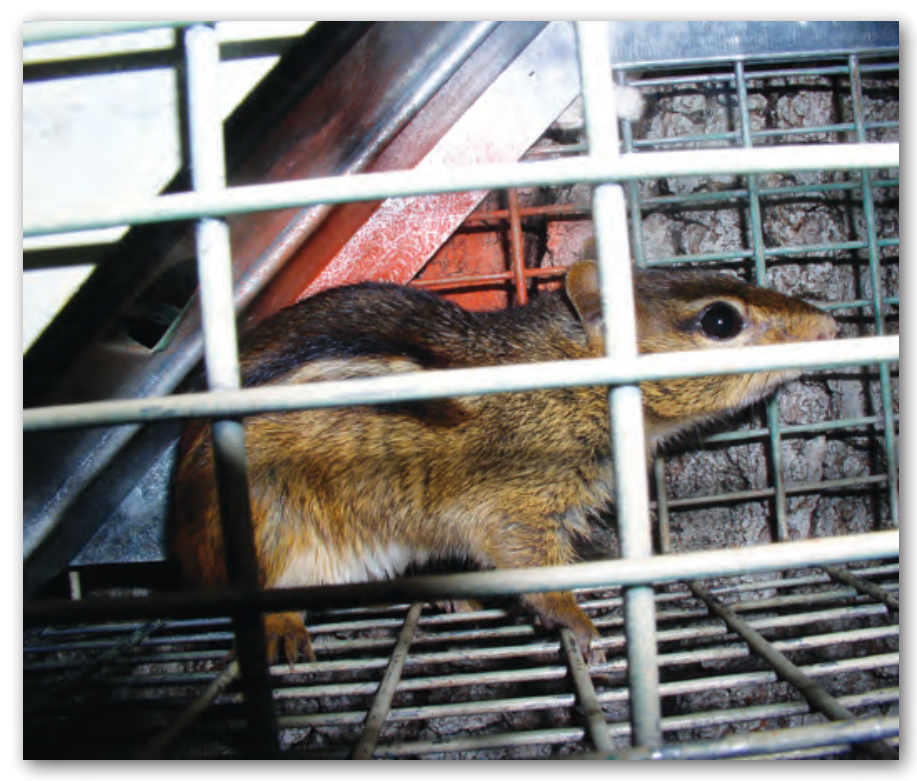


and Hamilton, 1998). Mixed forest does not occur at MORR and few wetlands and rocky features occur, resulting in little suitable habitat for this native felid. Bobcats also prefer thick understory cover (New Jersey Division of Fish and Wildlife, 2005c), which is uncommon at MORR except in areas dominated by Barberry. Deciduous forest with little understory cover is common, which makes the habitat within the park less than ideal for this species. Nevertheless, given the recent documentation of Bobcats in Morris County, and their need for a relatively large, contiguous area of natural habitat, there is a possibility that this species could occur at MORR.

Indiana Bats occur in New Jersey. A hibernating colony has been confirmed at Hibernia Mine (New Jersey Division of Fish and Wildlife, 2005d) in Hibernia, Morris County. Although this species has not been confirmed as occurring within MORR, the park does contain some conditions suitable for this bat. This species uses the bark of dead or dying trees in riparian areas and river floodplains as maternity roosts (New Jersey Division of Fish and Wildlife, 2005d). Trees along the Passaic River and Primrose Brook could serve as roosting areas during the summer months. The Indiana Bat also has been known to use elms, oaks, hickories, cottonwoods, Silver Maple (Acer saccharinum), and Green Ash (Fraxinus pennsylvanica) as maternity roosts (Kurta and others, 1993) and many of these trees occur within the park. Although we did not survey bats in this study, given the short distance between a major hibernation site and seemingly adequate summer roost sites in the park, the presence of this species in the park, particularly in summer, is possible.

Allegheny Woodrats are currently found in New Jersey on talus slopes of the Palisades near New York. They prefer rocky areas (Balcom and Yahner, 1995) such as talus slopes, cliffs, and caves (New Jersey Division of Fish and Wildlife, 2005a). Historically, this species was found in Morris County as evidenced from specimens collected during 1947-58 from Hibernia (probably associated with the mine) and Jefferson (Jefferson Mountain) Townships, plus the town of Newfoundland in 1908 (table 14 and unpublished data available from the American Museum of Natural History in New York). No significant rocky areas occur at MORR that would provide sufficient habitat for this species; therefore, this species is unlikely to occur at MORR. 


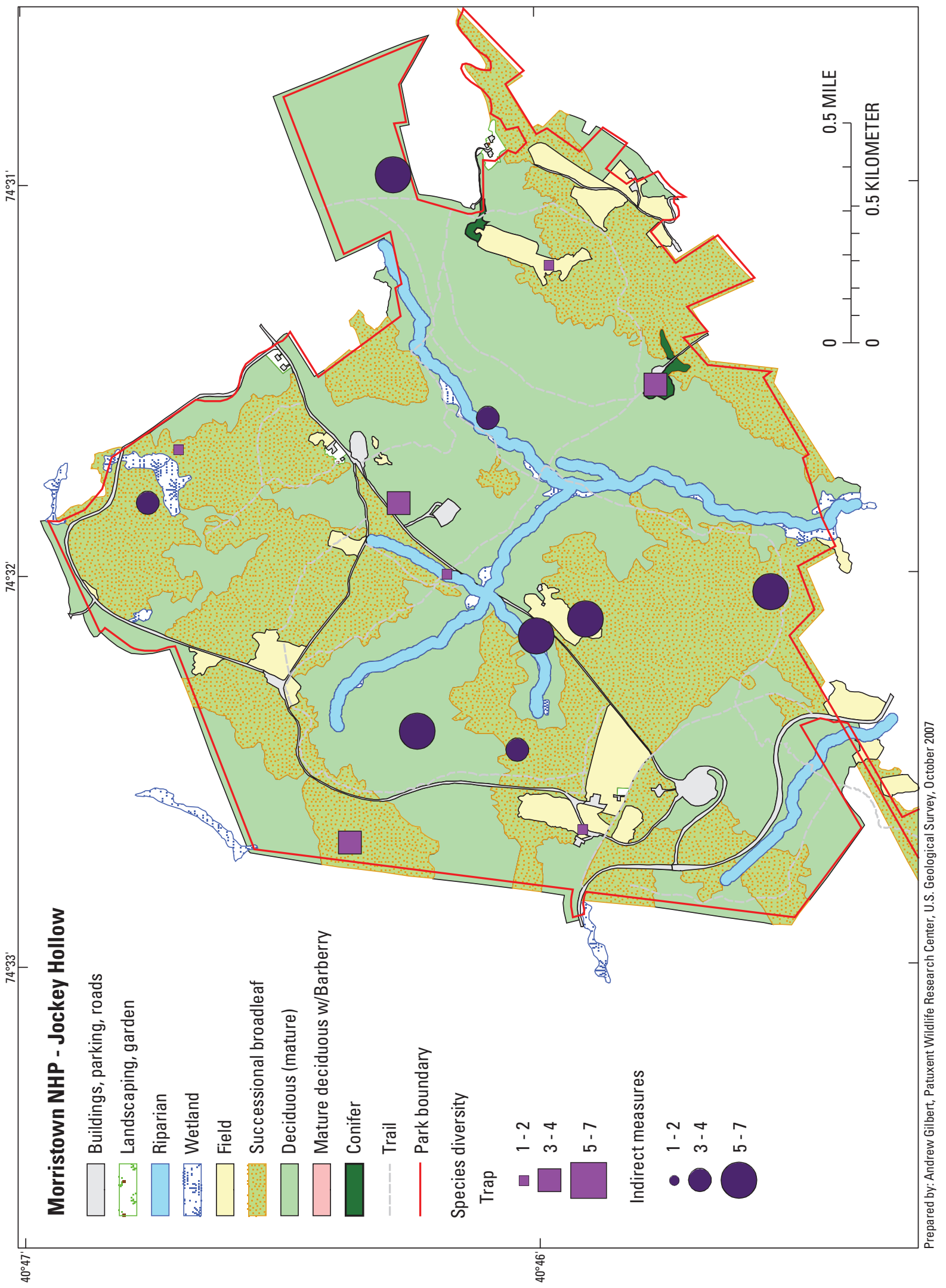

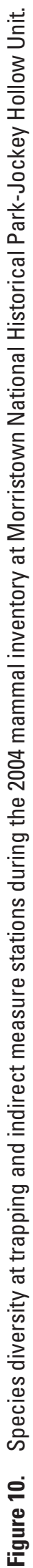




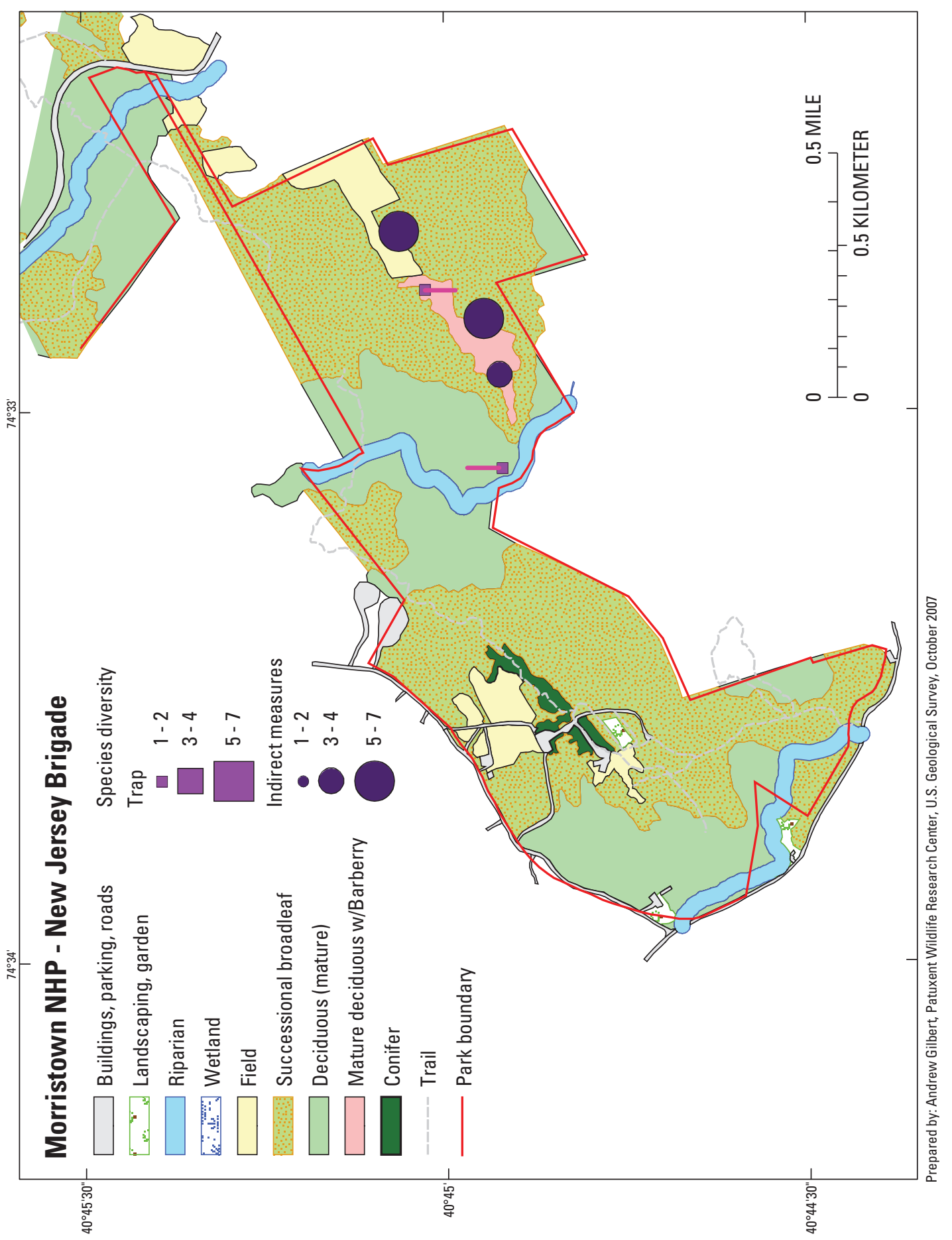


Table 14. Number of mammal specimens in museum collections and their proximity to Morristown National Historical Park.

[Proximity-to-park codes: 1, collected within park boundaries; 2, collected in the town (Bernardsville, Mendham, Morristown, N.J.) the park is located in; 3 , collected in the county (Morris, Somerset) the park is located in. Institutions: AMNH, American Museum of Natural History; CM, Carnegie Museum of Natural History; CUMV, Cornell University Museum of Vertebrates; FMNH, Field Museum of Natural History; KUNHM, University of Kansas, Natural History

Museum; UMMZ, University of Michigan Museum of Zoology. -, no specimens]

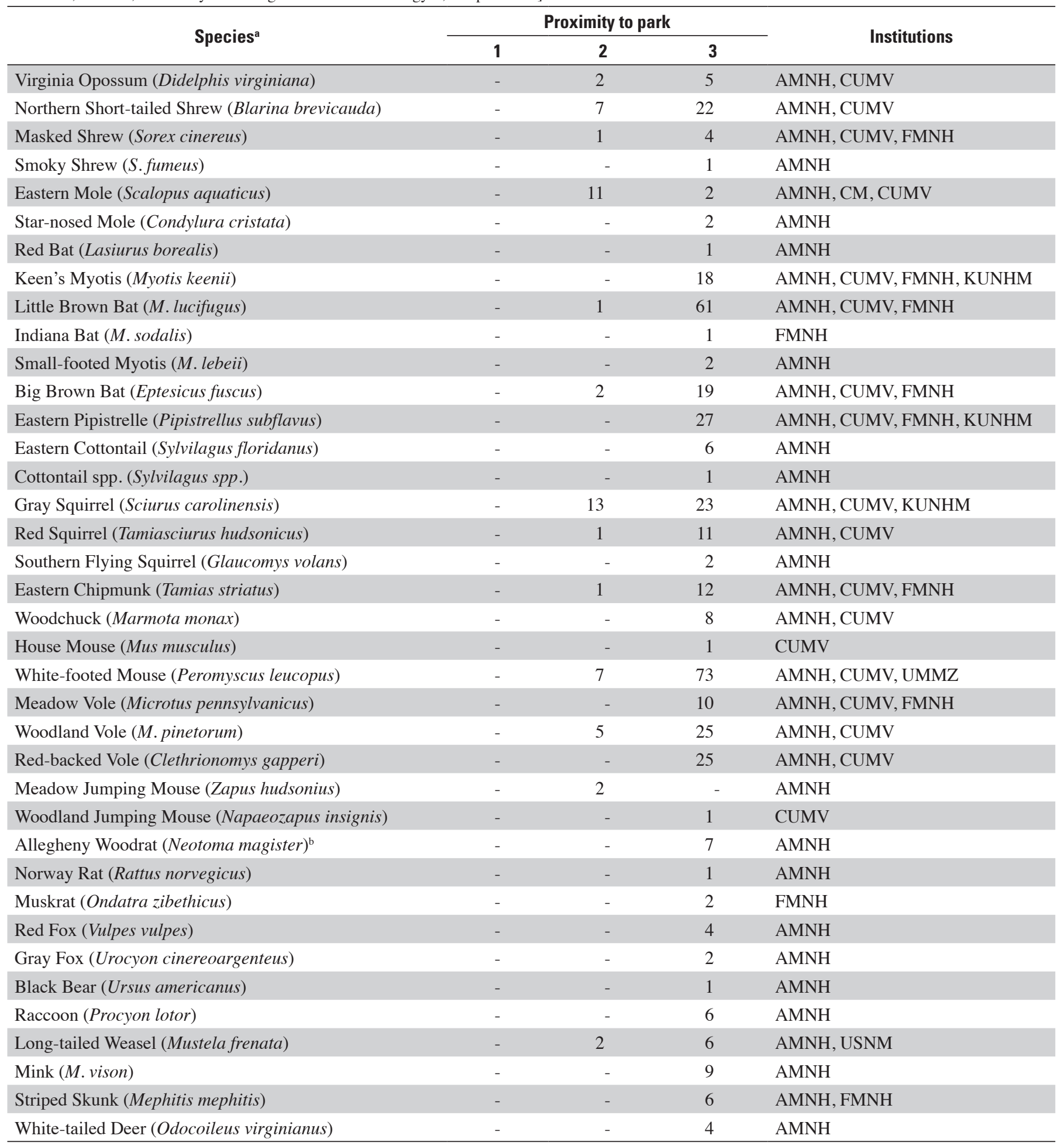

a Specimen data available through the National Park Service, NPSpecies database. For more information see: Gilbert and O'Connell, 2004; O'Connell and others, 2004; and A.F. O'Connell and A.T. Gilbert, unpublished data available at the USGS Patuxent Wildlife Research Center laboratory in Beltsville, Md.

${ }^{\mathrm{b}}$ Listed as Eastern Woodrat, but must be Allegheny Woodrat, which was split from the Eastern Woodrat (Neotoma floridana). 


\section{Roosevelt-Vanderbilt National Historic Sites (ROVA)}

\section{Background}

Roosevelt-Vanderbilt National Historic Site (ROVA) is made up of three separate historic sites in suburban Hyde Park, New York: the Vanderbilt Mansion National Historic Site (VAMA), Home of Franklin D. Roosevelt National Historic Site (HOFR), and Eleanor Roosevelt National Historic Site (ELRO). Totaling 315 ha, the parks are not connected but are near each other on a plateau above the Hudson River. Vegetation is dominated by northern hardwood mixed forest, although a large amount of open fields is maintained by periodic mowing in all three parks (David Hayes, National Park Service, oral commun., 2003). Streams pass through the parks and the Hudson River forms the western boundary of VAMA and HOFR. A large area of scrub-shrub and emergent wetland borders the Val-Kill stream at ELRO and a large emergent/ open-water wetland borders HOFR on the southwest boundary. The parks have substantial relief with long rocky outcrops running longitudinally through each park.

\section{Prior Research}

A survey of small mammals was conducted at ROVA during the summer of 1991 (Steadman, 1991). Sampling was conducted in both forest and field locations, and yielded five species of mammals including White-footed Mouse (Peromyscus leucopus), Smokey Shrew (Sorex fumeus), Northern Short-tailed Shrew (Blarina brevicauda), Meadow Vole (Microtus pennsylvanicus), and Meadow Jumping Mouse (Zapus hudsonius).

\section{Sampling Stations}

Indirect measure sampling was conducted in February and August of 2004 and trapping was conducted in August of 2004. We selected 24 sampling points in six community types prior to beginning field work. We conducted IM sampling at 12 , but trapped at only 11 stations, excluding one trapping station because it was too close to the ELRO residence in an unprotected area (table 15; figures 12-14).

\section{Survey Results}

Seventeen species were detected at ROVA, 13 during indirect measure sampling, 9 during trapping, and 3 by obser- vation. This is 31 percent of the potential number of mammal species that could occur in the park $(\mathrm{N}=55$, table 1$)$, excluding bats. At VAMA, 10 species were detected, 9 by IM sampling, 7 by trapping, and 1 by observation. The conifer community type was the most diverse at VAMA, with 10 species detected (table 16, fig. 15). At HOFR, 12 species were detected, 10 by IM sampling, 5 by trapping, and 1 by observation; mixed deciduous-conifer and riparian communities held the greatest diversity ( 8 species) (table 17, fig. 16). At ELRO, 12 species were detected, 8 by IM sampling, 4 by trapping, and 2 by observation. The most species (10) were detected within the wetland community type, followed closely by deciduous and riparian communities (table 18, fig. 17).

The Raccoon (Procyon lotor) was the most frequently detected and widely distributed medium-sized mammal at ROVA during both winter and summer sampling (table 19). Virginia Opossums (Didelphis virginiana) were also detected frequently in the summer, followed by the Domestic Cat (Felis silvestris) and Striped Skunk (Mephitis mephitis), which were detected during both seasons. White-footed Mice were numerous within the park and were caught at nearly all trapping stations. Northern Short-tailed Shrews were the next most frequently detected small mammal and were distributed widely across the park (table 20).

\section{Species Expected but Not Detected}

Although Red Foxes (Vulpes vulpes) and Coyotes (Canis latrans) were not detected, both species probably occur within the park. They are both native to New York, can occur in a diversity of habitats (Whitaker and Hamilton, 1998), and were encountered at most other parks within the Northeast Temperate Network, including Morristown NHP, Saratoga NHP, and Weir Farm NHS. A den was reported in a sandy bank below the Vanderbilt Mansion (David Hayes, National Park Service, oral commun., 2003), which is likely to be that of a Red Fox, given the propensity of this species to dig dens in sandy loam on hillsides, close to open areas (a large field in this case) (Whitaker and Hamilton, 1998). A Coyote was observed at Val-Kill (ELRO) in the recent past (David Hayes, National Park Service, oral commun., 2003).

Meadow Voles were the most frequently trapped small mammal during an earlier study at ROVA (Steadman, 1991), the specimens from which can be found at the New York State Museum (table 21), yet we did not catch this species despite trap placement in one of the fields used in the Steadman survey. Because the subject field had been cut just prior to trapping, voles may have moved to areas of greater cover (LoBue and Darnell, 1959). However, we did not capture Meadow Voles in another field location with seemingly adequate cover, suggesting that other reasons may be responsible for their 
Table 15. Indirect measure (IM) and trap station numbers, community type, GPS locations of the camera at IM stations and beginning of the Longworth trap lines, orientation of IM stations, and bearing of trap lines at Roosevelt-Vanderbilt National Historic Sites.

[Park unit code: ELRO, Eleanor Roosevelt National Historic Site; HOFR, Home of Franklin D. Roosevelt National Historic Site; VAMA, Vanderbilt Mansion National Historic Site]

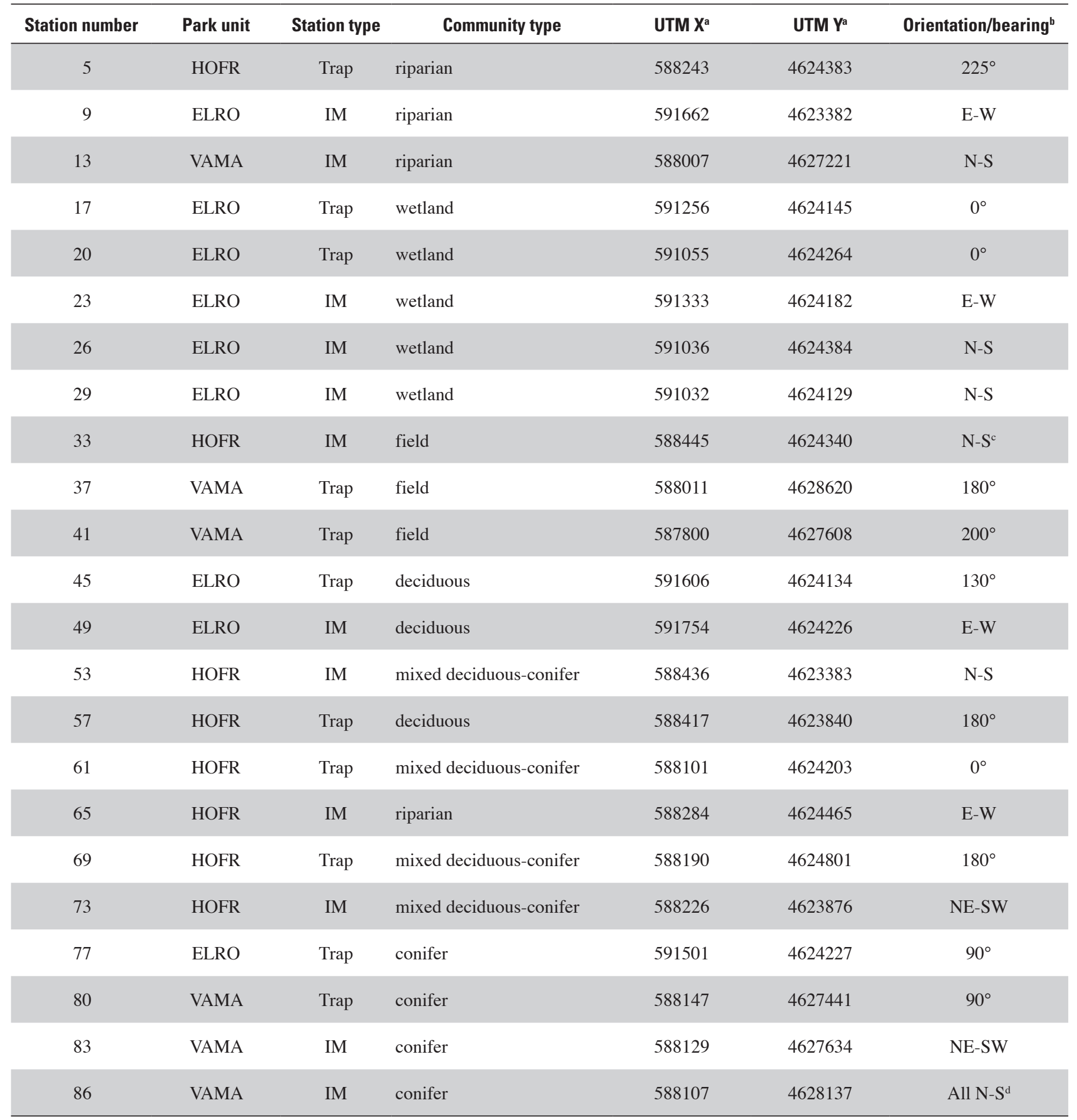

${ }^{a}$ Universal Transverse Mercator Zone 18; datum, North American Datum 1983; units, meters.

${ }^{\mathrm{b}}$ The orientation of the trackplates relative to the cameras in the indirect measure station or the bearing of the trap lines.

${ }^{\mathrm{c}}$ The camera at this station was stolen during the first sampling session and was not replaced for the second sampling session.

${ }^{d}$ All equipment was arranged in a north-south orientation because of community type and cultural constraints. This station was put in place only during the winter sampling session because of security considerations. 


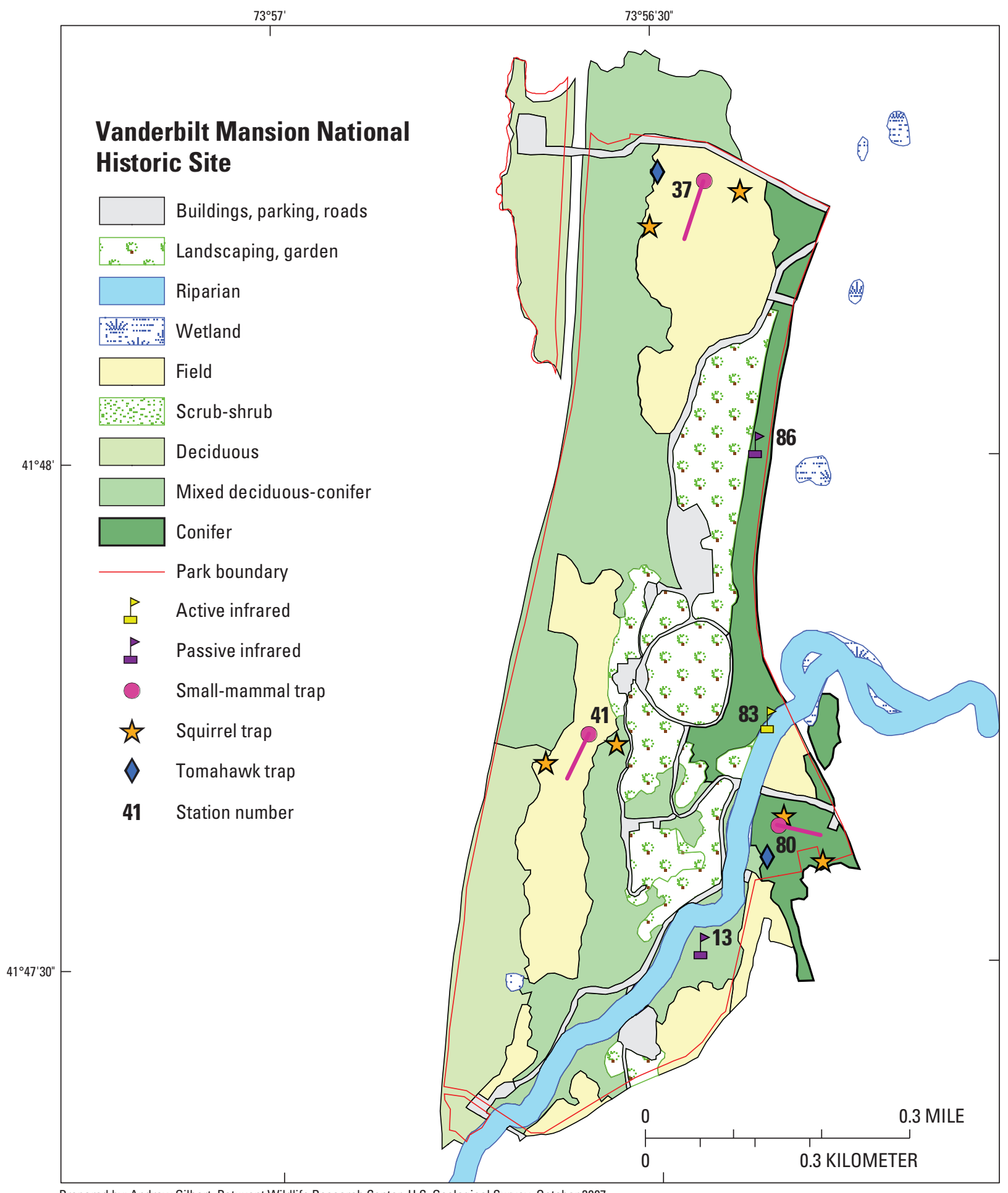

Figure 12. Locations of remote cameras and other detection devices, trapping equipment, and orientation of small-mammal trap lines used in the 2004 mammal inventory at Vanderbilt Mansion National Historic Site. (Two trackplates and two hair traps were arranged about 50 meters from each camera location. Two small-mammal trap lines (10 Longworth and 10 Museum special traps spaced 10 meters between traps) were set parallel to each other 10 meters apart and oriented as shown (pink lines). Two squirrel-sized live traps and, at some stations, a fox-sized live trap completed each trapping station. Station numbers are provided for sampling arrays.) 


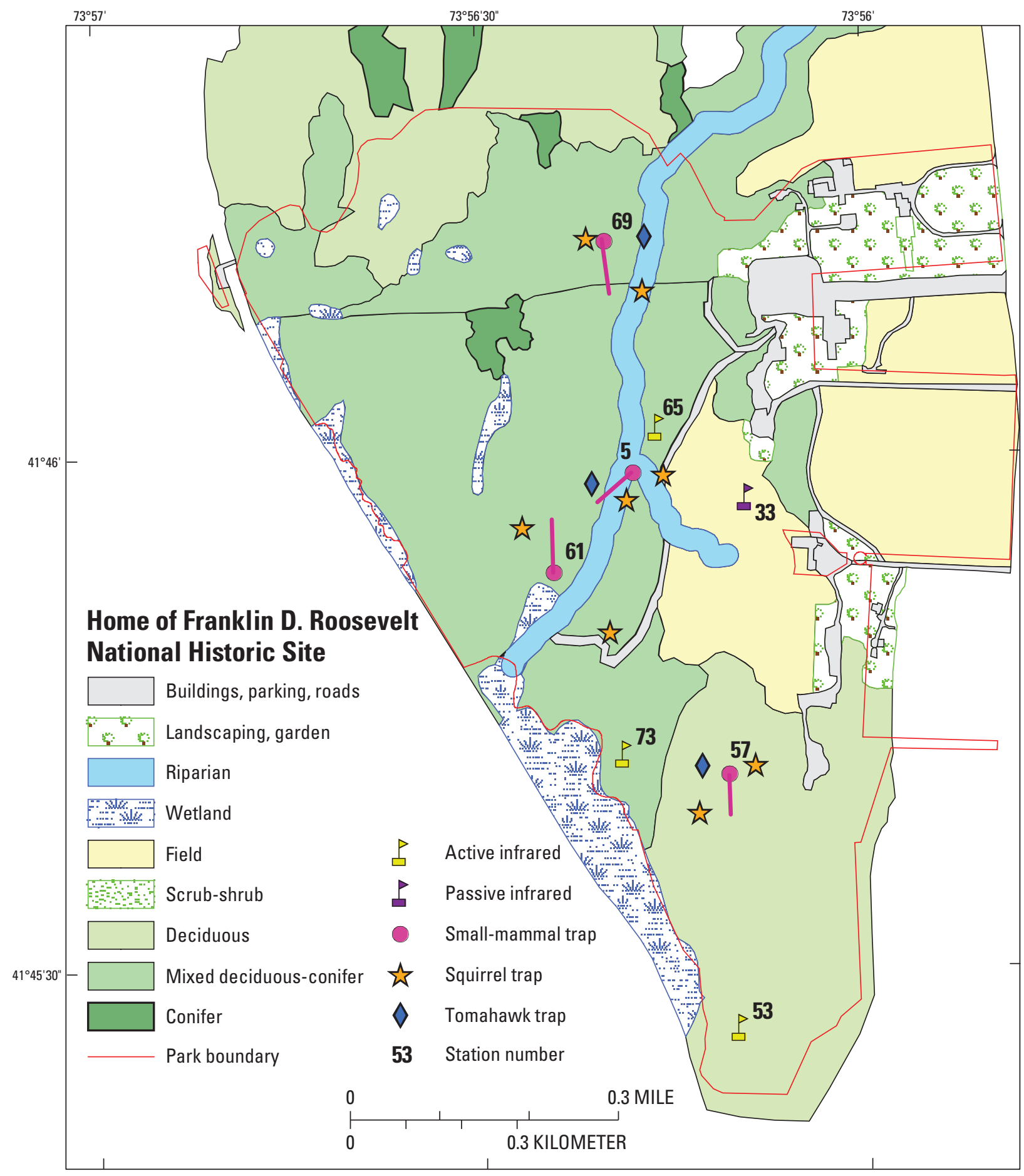

Figure 13. Locations of remote cameras and other detection devices, trapping equipment, and orientation of small-mammal trap lines used in the 2004 mammal inventory at Home of Franklin D. Roosevelt National Historic Site. (Two trackplates and two hair traps were arranged about 50 meters from each camera location. Two small-mammal trap lines (10 Longworth and 10 Museum special traps spaced 10 meters between traps) were set parallel to each other 10 meters apart and oriented as shown (pink lines). Two squirrel-sized live traps and, at some stations, a fox-sized live trap completed each trapping station. Station numbers are provided for sampling arrays.) 


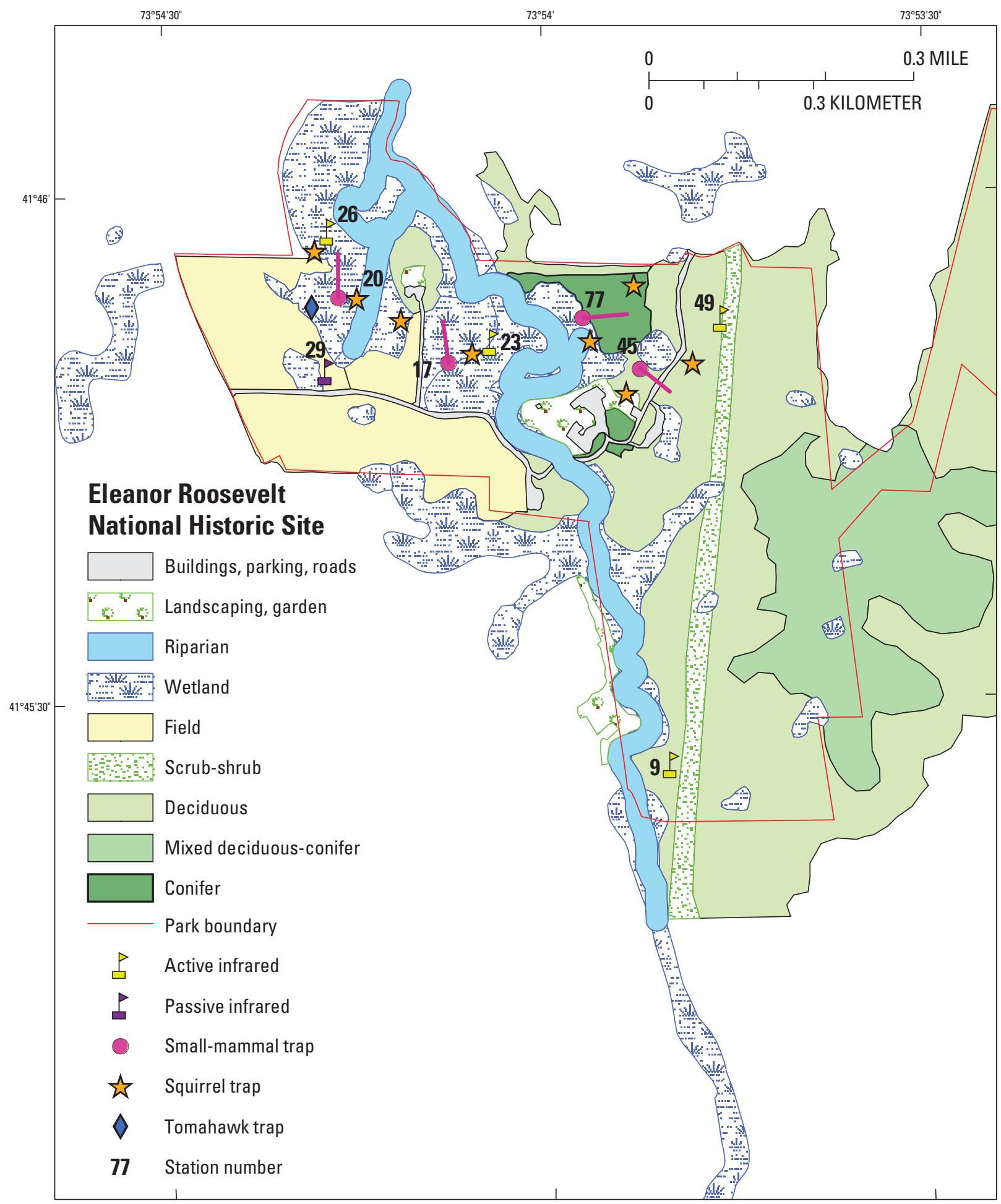

Figure 14. Locations of remote cameras and other detection devices, trapping equipment, and orientation of small-mammal trap lines used in the 2004 mammal inventory at Eleanor Roosevelt National Historic Site. (Two trackplates and two hair traps were arranged about 50 meters from each camera location. Two small-mammal trap lines (10 Longworth and 10 Museum special traps spaced 10 meters between traps) were set parallel to each other 10 meters apart and oriented as shown (pink lines). Two squirrel-sized live traps and, at some stations, a fox-sized live trap completed each trapping station. Station numbers are provided for sampling arrays.) 
Table 16. Community type associations of mammals detected at Vanderbilt Mansion National Historic Site by indirect measure sampling, trapping, and observation.

[Community type associations are based on vegetation community descriptions of each sampling location. C, camera; TP, trackplate; TR, trapping; X, species observed for which we have records; -, not detected]

\begin{tabular}{|c|c|c|c|c|c|c|}
\hline \multirow[b]{2}{*}{ Species detected } & \multicolumn{5}{|c|}{ Community type } & \multirow[b]{2}{*}{ Observed } \\
\hline & Conifer & Field & Lawn $^{a}$ & $\begin{array}{c}\text { Mixed } \\
\text { deciduous- } \\
\text { conifer }\end{array}$ & Riparian & \\
\hline Northern Short-tailed Shrew & - & TR & - & - & - & $\mathrm{X}$ \\
\hline Shrew spp. & $\mathrm{TP}$ & - & - & - & - & - \\
\hline Southern Flying Squirrel & $\mathrm{TP}$ & - & - & - & - & - \\
\hline Rat spp. or Eastern Chipmunk & $\mathrm{TP}$ & - & - & - & - & - \\
\hline White-footed Mouse & $\mathrm{TR}$ & TR & - & - & - & - \\
\hline Deer or White-footed Mouse & $\mathrm{TR}$ & - & - & - & - & - \\
\hline Meadow Jumping Mouse & - & TR & - & - & - & - \\
\hline Domestic Cat & $\mathrm{C}$ & - & - & - & $\mathrm{C}$ & - \\
\hline Total species detected ${ }^{\mathrm{b}}$ & 10 & 5 & 2 & 1 & 5 & 1 \\
\hline
\end{tabular}

Table 17. Community type associations of mammals detected at Home of Franklin D. Roosevelt National Historic Site by indirect measure sampling, trapping, and observation.

[Community type associations are based on vegetation community descriptions of each sampling location. C, camera; TP, trackplate; TR, trapping; X, species observed for which we have records; -, not detected]

\begin{tabular}{|c|c|c|c|c|c|c|}
\hline \multirow[b]{2}{*}{ Species detected } & \multicolumn{5}{|c|}{ Community type } & \multirow[b]{2}{*}{ Observed } \\
\hline & Deciduous & Field & $\begin{array}{c}\text { Mixed } \\
\text { deciduous- } \\
\text { conifer } \\
\end{array}$ & Riparian & Wetland & \\
\hline Northern Short-tailed Shrew & - & - & TR & TR & - & - \\
\hline Eastern Chipmunk & - & - & $\mathrm{TR}$ & - & - & - \\
\hline Rat spp. or Eastern Chipmunk & - & - & - & - & $\mathrm{TP}$ & - \\
\hline Squirrel spp. & - & $\mathrm{TP}$ & - & - & - & - \\
\hline Woodchuck & - & - & - & - & $\mathrm{TP}$ & $\mathrm{X}$ \\
\hline White-footed Mouse & TR & - & TR & TR & - & - \\
\hline Deer or White-footed Mouse & $\mathrm{TR}$ & - & $\mathrm{TR}$ & $\mathrm{TR}$ & - & - \\
\hline Mink & - & - & - & $\mathrm{TP}$ & - & - \\
\hline Striped Skunk & - & $\mathrm{TP}$ & $\mathrm{C}$ & - & - & - \\
\hline Domestic Cat & - & - & - & $\mathrm{C}$ & - & - \\
\hline White-tailed Deer & - & - & $\mathrm{C}$ & $\mathrm{C}$ & - & - \\
\hline Total species detected ${ }^{\mathrm{a}}$ & 3 & 5 & 8 & 8 & 4 & 1 \\
\hline
\end{tabular}


Table 18. Community type associations of mammals detected at Eleanor Roosevelt National Historic Site by indirect measure sampling, trapping, and observation.

[Community type associations are based on vegetation community descriptions of each sampling location. C, camera; TP, trackplate; TR, trapping; X, species observed for which we have records; -, not detected]

\begin{tabular}{|c|c|c|c|c|c|c|}
\hline \multirow{2}{*}{ Species detected } & \multicolumn{5}{|c|}{ Community type } & \multirow{2}{*}{ Observed } \\
\hline & Conifer & Deciduous & Field & Riparian & Wetland & \\
\hline Virginia Opossum & - & $\mathrm{C}, \mathrm{TP}$ & - & $\mathrm{C}, \mathrm{TP}$ & $\mathrm{C}, \mathrm{TP}, \mathrm{TR}$ & - \\
\hline Eastern or New England Cottontail & - & - & - & - & - & $\mathrm{X}$ \\
\hline Gray Squirrel & - & - & - & - & TR & - \\
\hline Red Squirrel & - & $\mathrm{TP}$ & - & - & TR & - \\
\hline Woodchuck & - & - & - & $\mathrm{TP}$ & - & $\mathrm{X}$ \\
\hline Deer or White-footed Mouse & - & TR & - & - & TR & - \\
\hline Mouse/Vole spp. & - & $\mathrm{TP}$ & $\mathrm{TP}$ & $\mathrm{TP}$ & $\mathrm{TP}$ & - \\
\hline Mouse/Vole/Shrew spp. & - & $\mathrm{TP}$ & - & $\mathrm{TP}$ & $\mathrm{TP}$ & - \\
\hline Gray Fox & - & - & - & $\mathrm{C}$ & $\mathrm{C}$ & - \\
\hline Raccoon & - & $\mathrm{C}, \mathrm{TP}$ & TP & $\mathrm{C}, \mathrm{TP}$ & $\mathrm{C}, \mathrm{C}, \mathrm{TP}$ & - \\
\hline White-tailed Deer & - & $\mathrm{C}$ & - & $\mathrm{C}$ & $\mathrm{C}$ & - \\
\hline Total species detected $^{\mathrm{a}}$ & 1 & 7 & 2 & 7 & 10 & 2 \\
\hline
\end{tabular}

${ }^{a}$ Totals exclude generic counts unless no other species in that group were detected (for example, Shrew spp. would be counted if no other specific shrew was detected).

Table 19. Mammal species detection rates and site occupancy at 12 indirect measure stations at Roosevelt-Vanderbilt National Historic Site during two sampling sessions in 2004.

$[-$, species not detected]

\begin{tabular}{|c|c|c|c|c|}
\hline \multirow{2}{*}{ Species detected } & \multicolumn{2}{|c|}{$\begin{array}{c}\text { Session } 1 \\
(2 / 7 / 2004-2 / 23 / 2004) \\
\end{array}$} & \multicolumn{2}{|c|}{$\begin{array}{c}\text { Session } 2 \\
(8 / 2 / 2004-8 / 18 / 2004)\end{array}$} \\
\hline & $\begin{array}{c}\text { Number of stations } \\
\text { occupied (proportion) }\end{array}$ & $\begin{array}{l}\text { Mean detection rate } \\
(\mathrm{SE})^{\mathrm{a}}\end{array}$ & $\begin{array}{c}\text { Number of stations } \\
\text { occupied (proportion) }\end{array}$ & $\begin{array}{c}\text { Mean detection rate } \\
(\mathrm{SE})^{\mathrm{a}}\end{array}$ \\
\hline Shrew spp. & $1(0.08)$ & $0.02(0.02)$ & - & - \\
\hline Rat spp. or Eastern Chipmunk & - & - & $2(0.17)$ & $0.03(0.02)$ \\
\hline Southern Flying Squirrel & $2(0.17)$ & $0.04(0.02)$ & $1(0.08)$ & $0.01(0.01)$ \\
\hline Squirrel spp. & $1(0.08)$ & $0.01(0.01)$ & - & - \\
\hline Woodchuck & - & - & $2(0.17)$ & $0.03(0.02)$ \\
\hline Mouse/Vole spp. & $9(0.75)$ & $0.44(0.12)$ & $7(0.58)$ & $0.12(0.04)$ \\
\hline Mink & $1(0.08)$ & $0.01(0.01)$ & - & - \\
\hline Striped Skunk & $5(0.42)$ & $0.18(0.07)$ & $4(0.33)$ & $0.10(0.05)$ \\
\hline Domestic Cat & $3(0.25)$ & $0.09(0.06)$ & $6(0.50)$ & $0.12(0.06)$ \\
\hline White-tailed Deer & $4(0.33)$ & $0.09(0.04)$ & $1(0.08)$ & $0.03(0.03)$ \\
\hline
\end{tabular}


apparent absence. The highly cyclical nature and resulting low population densities of this species (Ostfield and Canham, 1995, and references therein) may have been the cause of our inability to detect this species. Nevertheless, this species is common throughout the Northeast and we suspect that it still occurs within the park.

Smoky Shrews were captured during the previous mammal survey at MORR (Steadman, 1991) (table 21), but were not detected in this survey. We believe that this rather common species does occur in the park but did not expect to detect Beaver (Castor canadensis) by IM sampling or our trapping methods. An inactive beaver lodge and dam were visible on Fall Kill in ELRO. Beavers have also been found dead on the roadside at VAMA (David Hayes, National Park Service, oral commun., 2003) and are probably associated with Crum Elbow Creek. River Otters (Lontra canadensis) have also been observed on the Fall Kill by park staff (David Hayes, National Park Service, oral commun., 2003). Beavers and River Otters both would be expected to occur along the streams and ponds of the park units.

\section{Endangered and Threatened Species}

We did not detect any species that are listed as state or federally threatened or endangered. The State of New York lists the Indiana Bat (Myotis sodalis), Allegheny Woodrat (Neotoma magister), Gray Wolf (Canis lupus), and Eastern Cougar (Felis concolor cougar) as endangered and the Canada Lynx (Lynx canadensis) as threatened. However, only the Indiana Bat has not been extirpated from New York (New York State Department of Environmental Conservation, 2005f) and is most likely to occur in the park. Small-footed Myotis (Myotis leibii) and New England Cottontails (Sylvilagus transitionalis) are listed as species of special concern.

Indiana Bats are known to occur in eastern New York and have been documented wintering in eight hibernacula in Albany, Essex, Warren, Jefferson, Onondaga, and Ulster Counties (New York State Department of Environmental Conservation, 2005e). Even though this species has not been found wintering in Dutchess County, one or more known hibernacula occur to the west in Ulster County. It is possible that hibernacula will be found in the future and Indiana Bats may feed or have nursery colonies within the park. Maternity roosts are found under the loose bark of trees and this species has been known to use elms, oaks, hickories, Cottonwood (Populus deltoides), Silver Maple (Acer saccharinum), and Green Ash (Fraxinus pennsylvanica) (Kurta and others, 1993); many of these trees occur in great abundance at ROVA. Indiana Bats prefer riparian and floodplain trees (Thomson, 1982), which are also prevalent at ROVA. We did not survey bats as part of this study, and do not have any evidence that this species occurs in the park. However, given the proximity to known hibernacula and the presence of appropriate summer roost sites, the presence of this species seems possible.

Allegheny Woodrat was once found on cliffs and talus slopes of southeastern New York, but are believed to have been extirpated from the state by 1987 (New York State Department of Environmental Conservation, 2005a). Its decline may be linked to the increase in Raccoons and their susceptibility to Raccoon Roundworm (Baylisascaris procyonis) (New York State Department of Environmental Conservation, 2005a) or climatic change (Whitaker and Hamilton, 1998); whatever the case, the future occurrence of Allegheny Woodrat in the state is unlikely (New York State Department of Environmental Conservation, 2005a). Some rocky outcroppings are present at ROVA, but probably do not offer the ideal habitat for this species. We did not expect Allegheny Woodrat to occur at ROVA.

Both Cougar and the Gray Wolf were extirpated from New York State during colonial times (Connor, 1971). Although the State of New York has considered reintroduction of the Gray Wolf in the Adirondack Mountain region as

Table 20. Mammal capture rates and site occupancy for 11 trapping stations (6 with fox-sized live traps) at Roosevelt-Vanderbilt National Historic Site during sampling session 2 (8/2/2004-8/18/2004).

\begin{tabular}{|c|c|c|c|}
\hline Species Detected & $\begin{array}{c}\text { Number of } \\
\text { new captures }\end{array}$ & $\begin{array}{c}\text { Number of stations occupied } \\
\text { (proportion) }^{\mathrm{a}}\end{array}$ & $\begin{array}{c}\text { Mean rate of new individuals } \\
\text { captured }(\mathrm{SE})^{\mathrm{b}}\end{array}$ \\
\hline Virginia Opossum & 3 & $3(0.50)$ & $0.10(0.04)$ \\
\hline Northern Short-tailed Shrew & 9 & $5(0.45)$ & $0.16(0.08)$ \\
\hline Eastern Chipmunk & 1 & $1(0.09)$ & $0.02(0.02)$ \\
\hline Gray Squirrel & 4 & $4(0.36)$ & $0.07(0.03)$ \\
\hline Red Squirrel & 2 & $2(0.18)$ & $0.04(0.03)$ \\
\hline Meadow Jumping Mouse & 1 & $1(0.09)$ & $0.02(0.02)$ \\
\hline Raccoon & 4 & $4(0.67)$ & $0.13(0.04)$ \\
\hline Domestic Cat & 1 & $1(0.17)$ & $0.03(0.02)$ \\
\hline
\end{tabular}


part of the recovery program in the northeastern United States (New York State Department of Environmental Conservation, 2005d), there is no plan to reintroduce Cougars to New York (New York State Department of Environmental Conservation, 2005c). Cougars are occasionally observed throughout New York, but they are probably pets that have been released to the wild (New York State Department of Environmental Conservation, 2005c).

Canada Lynx are unlikely to be resident within the area around ROVA, although historical records indicate a much broader distribution throughout the Northeast that includes New York prior to 1900 (Hoving and others, 2003). Lynx were considered relatively common in the Adirondacks and were recorded east of Albany, but became rare as of the late $1800 \mathrm{~s}$ (Hoving and others, 2003). Only 23 records are available from the 1900s, most of which originate from the Adirondacks (McKelvey and others, 1999). If Lynx do occur in New York, they are likely to be found in high-elevation boreal forest in the northern part of the state. In fact, a reintroduction of 83 Lynx was attempted during 1989-91 in the Adirondacks, but this effort is believed to have failed (McKelvey and others, 1999). Canada Lynx thrive in areas of deep snow through which they can pursue their preferred prey, Snow shoe Hare (Whitaker and Hamilton, 1998; Hoving and others, 2005). Recent modeling efforts have shown that Canada Lynx is unlikely to occur in areas with $<270 \mathrm{~cm} / \mathrm{yr}$ of snow or areas dominated by deciduous forest (Hoving and others, 2005). Total annual snowfall averages $96 \mathrm{~cm}$ for nearby Poughkeepsie, N.Y. (National Climatic Data Center, 2006a), and so Lynx are not predicted to inhabit this region of New York.
Small-footed Myotis is considered one of the rarest bats in North America and is found in mountainous regions throughout the Northeast, including New York (Best and Jennings, 1997). They hibernate in caves or mines, but little is known about their summer habits (Whitaker and Hamilton, 1998). Given the lack of information about this species, it is not possible to state if it occurs in ROVA.

The New England Cottontail (Sylvilagus transitionalis) is a species of special concern in New York. The Federal government was petitioned to list the species as federally threatened or endangered, and the listing status was recently updated to level two for final determination on the proposed listing (CFR 50-17; 06:53756-53835). The range of the New England Cottontail is believed to be much reduced from its former range (Litvaitis and others, 2003), but the species does occur west to the Hudson River Valley (Whitaker and Hamilton, 1998). This lagomorph is closely related to, and can be confused with, the Eastern Cottontail (S. floridanus), which is found throughout New York. New England Cottontails prefer dense thickets (Litvaitis and others, 2003; U.S. Fish and Wildlife Service, 2005b) and this community type is present in ROVA. Although no specimen is known from the park, an unidentified cottontail was observed in the park (table 16) and a New England Cottontail was taken in Dutchess County during the 1994-95 hunting season (Whitaker and Hamilton, 1998). DNA analysis (tissue or fecal material) or examination of skull structure is required to identify, and distinguish between, these two lagomorphs (Whitaker and Hamilton, 1998; U.S. Fish and Wildlife Service, 2005b.

Table 21. Number of mammal specimens in museum collections and their proximity to Roosevelt-Vanderbilt National Historic Sites.

[Proximity-to-park codes: 1, collected within park boundaries; 2, collected in the town (Hyde Park, N.Y.) the park is located in; 3 , collected in the county (Dutchess) the park is located in. Institutions: AMNH, American Museum of Natural History; CUMV, Cornell University Museum of Vertebrates; KUNHM, University of Kansas, Natural History Museum; MCZ, Harvard University, Museum of Comparative Zoology; NYSM, New York State Museum. -, no specimens]

\begin{tabular}{|c|c|c|c|c|}
\hline \multirow[b]{2}{*}{ Species $^{a}$} & \multicolumn{3}{|c|}{ Proximity to park } & \multirow[b]{2}{*}{ Institutions } \\
\hline & 1 & 2 & 3 & \\
\hline Virginia Opossum (Didelphis virginiana) & - & - & 2 & AMNH \\
\hline Smoky Shrew (Sorex fumeus) & 11 & - & - & NYSM \\
\hline Big Brown Bat (Eptesicus fuscus) & - & - & 2 & AMNH, CUMV \\
\hline Brown Hare (Lepus capensis) & - & - & 1 & KUMNH \\
\hline Woodchuck (Marmota monax) & - & - & 2 & AMNH \\
\hline White-footed Mouse (Peromyscus leucopus) & 18 & - & 1 & AMNH, NYSM \\
\hline Meadow Vole (Microtus pennsylvanicus) & 27 & - & - & NYSM \\
\hline Meadow Jumping Mouse (Zapus hudsonius) & 1 & - & 1 & AMNH, NYSM \\
\hline Beaver (Castor canadensis) & - & - & 3 & CUMV \\
\hline European Wild Boar (Sus scrofa) & - & - & 1 & AMNH \\
\hline
\end{tabular}




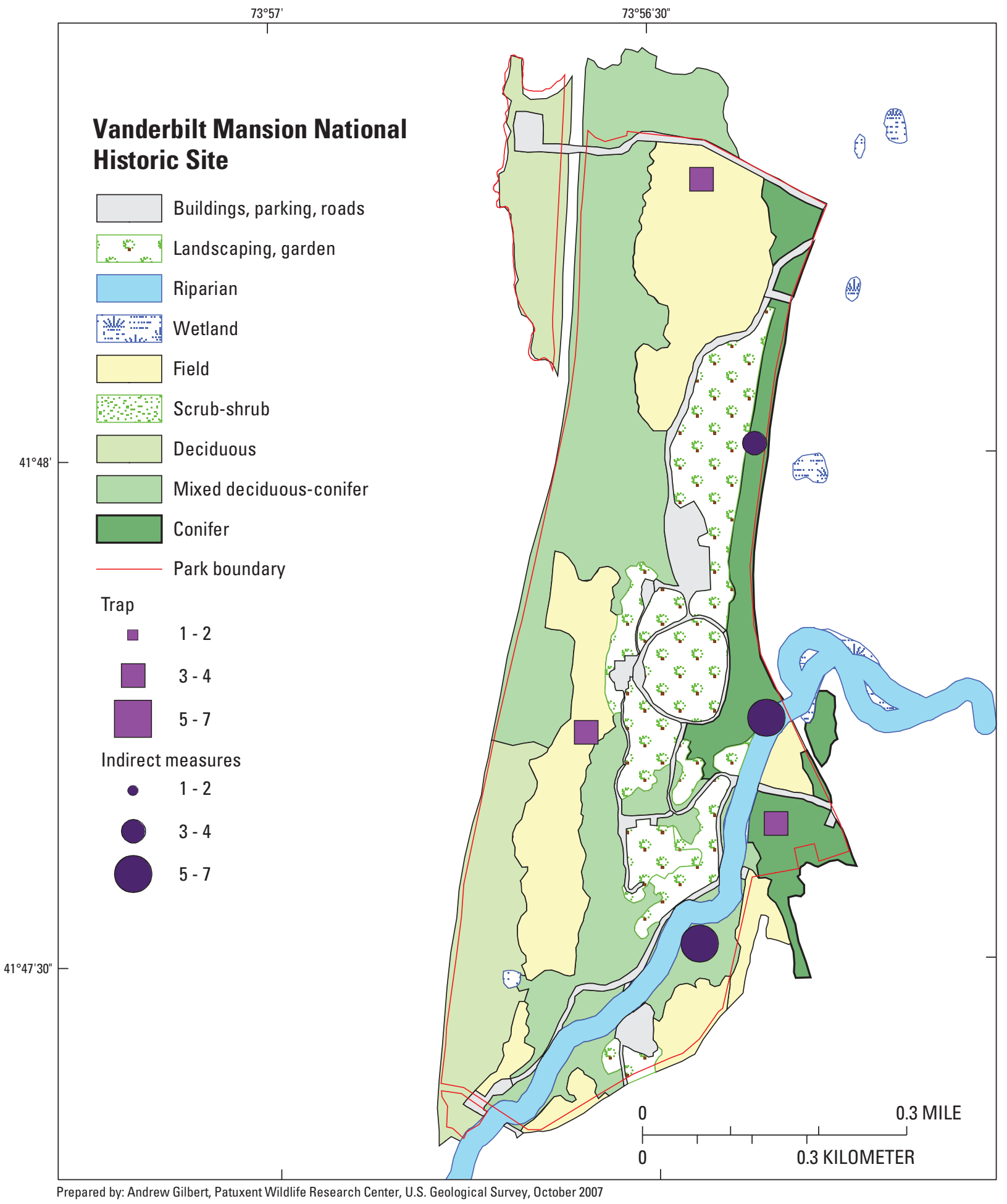

Figure 15. Species diversity at trapping and indirect measure sampling stations during the 2004 mammal inventory at Vanderbilt Mansion National Historic Site. 


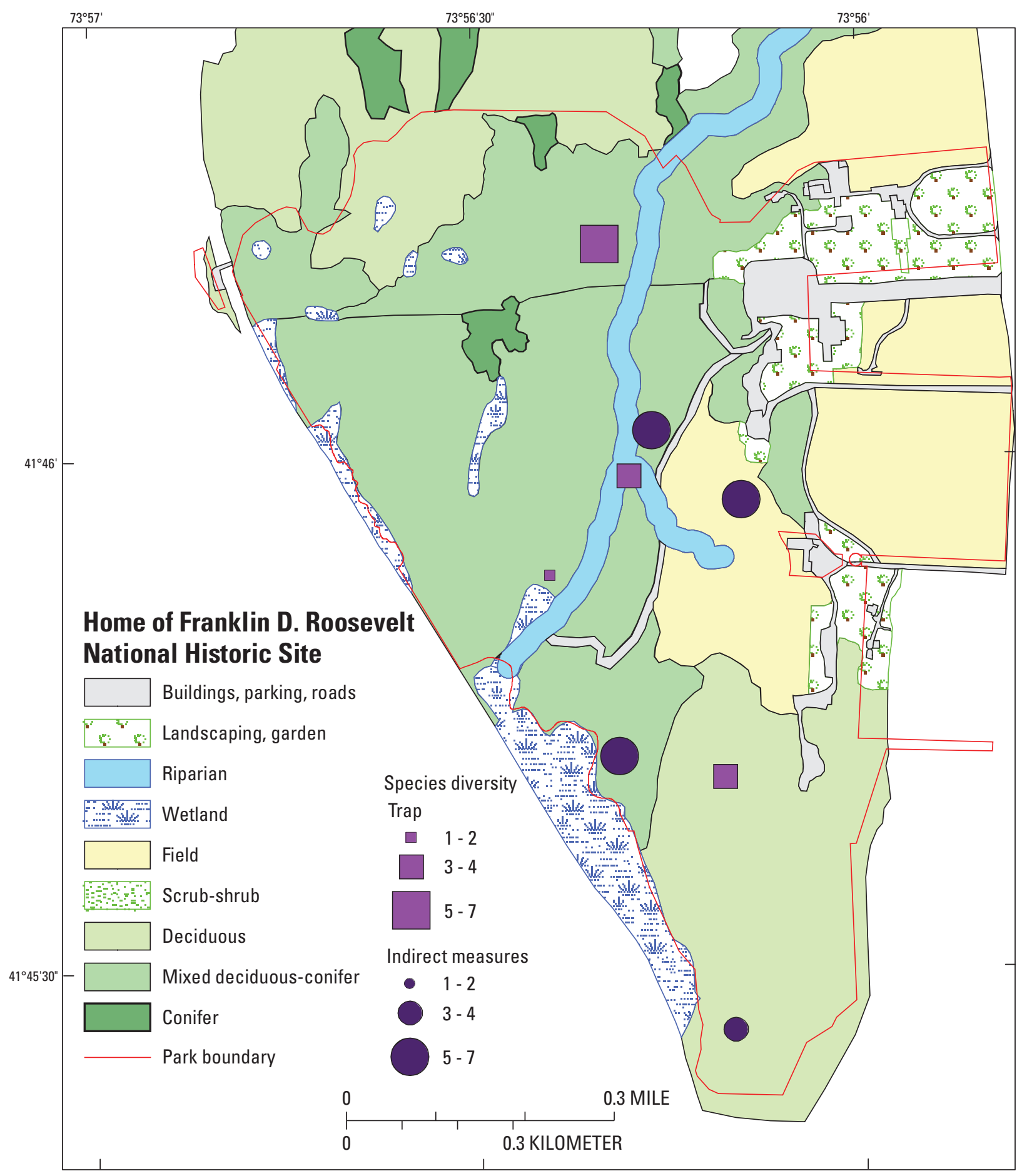

Figure 16. Species diversity at trapping and indirect measure sampling stations during the 2004 mammal inventory at Home of Franklin D. Roosevelt National Historic Site. 


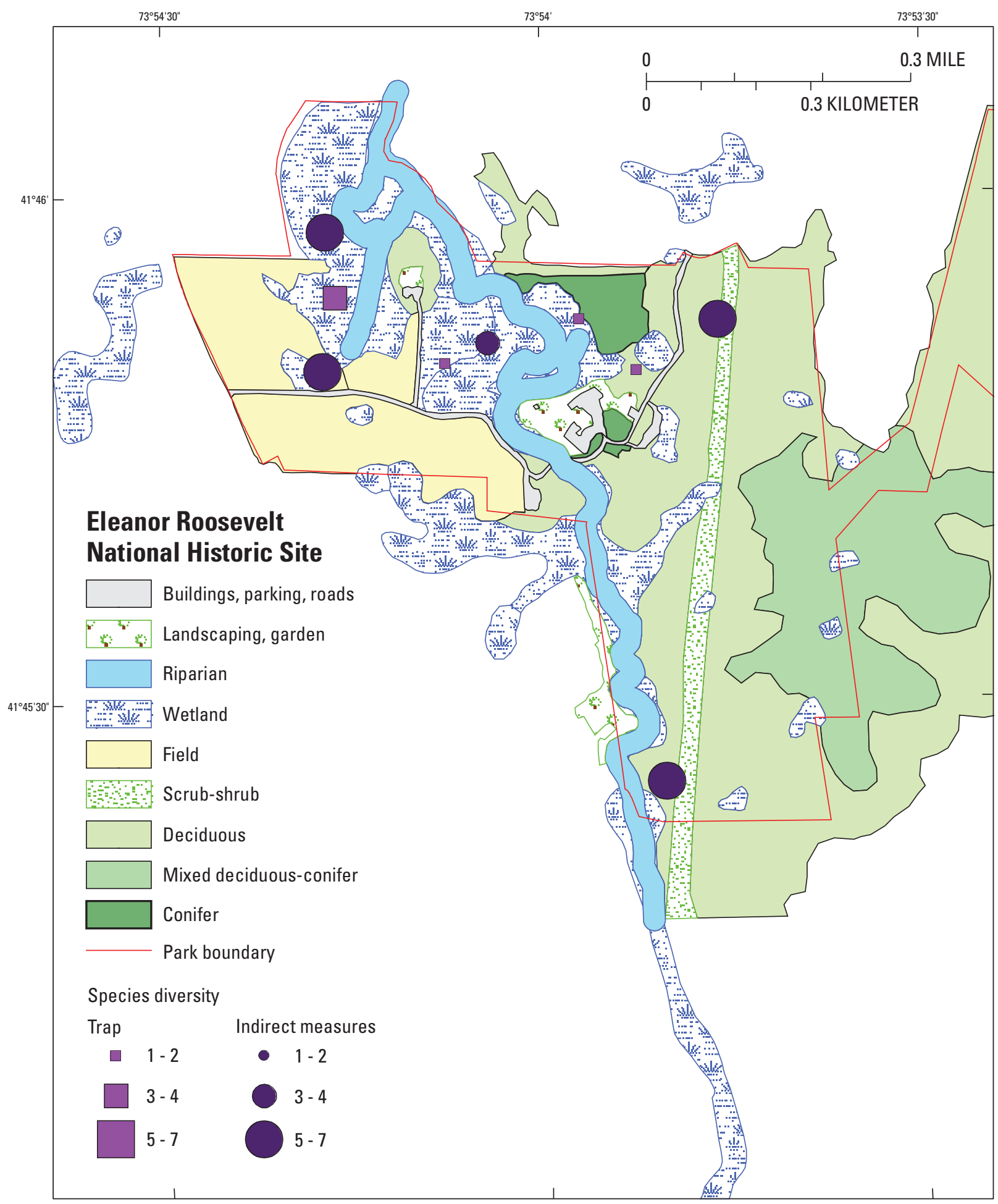

Figure 17. Species diversity at trapping and indirect measure sampling stations during the 2004 mammal inventory at Eleanor Roosevelt National Historic Site. 


\section{Minute Man National Historical Park (MIMA)}

\section{Background}

Minute Man National Historical Park (MIMA) is well known for its battlegrounds that marked the beginning of the Revolutionary War. At 391 ha, and stretching nearly $9 \mathrm{~km}$ through suburban/urban landscape about $20 \mathrm{~km}$ west of Boston, Massachusetts, MIMA occupies a long, thin corridor in a heavily populated region. However, other parks and refuges lie near MIMA, increasing the total amount of open space in the area. Great Meadows National Wildlife Refuge (NWR) is connected to the park by the Concord River and $<1 \mathrm{~km}$ north of the North Bridge unit at the western edge of MIMA. Great Meadows NWR contains nearly $20 \mathrm{~km}$ of river and more than 1,500 ha of protected area (U.S. Fish and Wildlife Service, 2005a). Walden Pond State Reservation, famed for its association with the naturalist Henry David Thoreau, lies $2 \mathrm{~km}$ south of MIMA and is another important refuge and recreation area. MIMA is a mixture of deciduous and mixed deciduousconifer forest, wetlands, and fields (Mitchell and others, 2006). Although no large ponds or lakes occur in the park, the Concord River passes through the North Bridge Unit and is an important natural resource.

\section{Prior Investigations}

A study of Hantavirus antibody in populations of small mammals was conducted in 1994 in national parks across the United States, including MIMA (Mills and others, 1998). White-footed Mouse (Peromyscus leucopus) and Deer Mouse (P. maniculatus) were trapped and tested for reactivity to Sin Nombre virus at MIMA. No animals from MIMA tested positive for antibody reactivity.

The ecological effects of roads on wildlife were studied in an area adjacent to MIMA along the Route 2 corridor between U.S. Route 128 and U.S. Route 495 (Forman and Deblinger, 2000). The effects of salt intrusion, avoidance by birds, and invasion by exotic plants have been detected up to $1 \mathrm{~km}$ from the road. This study also identified areas where White-tailed Deer congregate and Moose corridors, and included observations of Moose in the vicinity of the park.

\section{Sampling Stations}

Indirect measure sampling was conducted in March and July of 2004 and trapping was conducted in July of 2004 at MIMA. Prior to field work, we selected 24 locations as sampling stations, but we only established 22 sampling stations (12 IM and 10 trap) in six community types (table 22; figures 18-19). We limited trapping to 10 stations at MIMA because of logistics and time constraints imposed by the handling of many captures at the first station we established.

\section{Survey Results}

Twenty-four species were detected at MIMA: 19 during IM sampling, 14 during trapping, and 4 by observation (table 23 ). This is 50 percent of the potential number of mammal species that could occur in the park $(\mathrm{N}=48$, table 1$)$, excluding bats. MIMA is located near a very large metropolitan area (Boston) and yet we detected more species there than at other parks in this survey. Raccoons (Procyon lotor) were the most frequently detected medium-sized mammal during the winter, followed closely by Fisher (Martes pennanti) and Red Fox (Vulpes vulpes) (table 24). During the summer sampling session, the Virginia Opossum (Didelphis virginiana) and Raccoon were the most commonly detected and widely distributed species and were found at almost all stations (table 24). Striped Skunks (Mephitis mephitis) were the next most frequently detected species during summer. Virginia Opossums and Striped Skunks become less active during winter due to thermoregulatory constraints and spend extended periods in their den sites (Whitaker and Hamilton, 1998); this probably accounts for some of the differences we observed in detection rates for these species between seasons.

The frequency with which we detected Fisher during the winter sampling session was surprising given the suburban/ urban nature of the surrounding area. Whitaker and Hamilton (1998) describe Fisher as residents of continuous forest, "at home only where the wild country has not been invaded by humans;" however, this mustelid appears to be adapting to life in suburban areas. Fishers were detected across MIMA in all community types and at more than half of all IM stations (tables 23-24). Fisher range widely, with home ranges varying from 15 to $35 \mathrm{~km}^{2}$, and they have been known to travel 20 to $30 \mathrm{~km}$ per day (Powell, 1981). A few Fisher could have been responsible for the majority of detections at MIMA, but because we did not capture and mark individuals, it is impossible to estimate the population size of this species at MIMA.

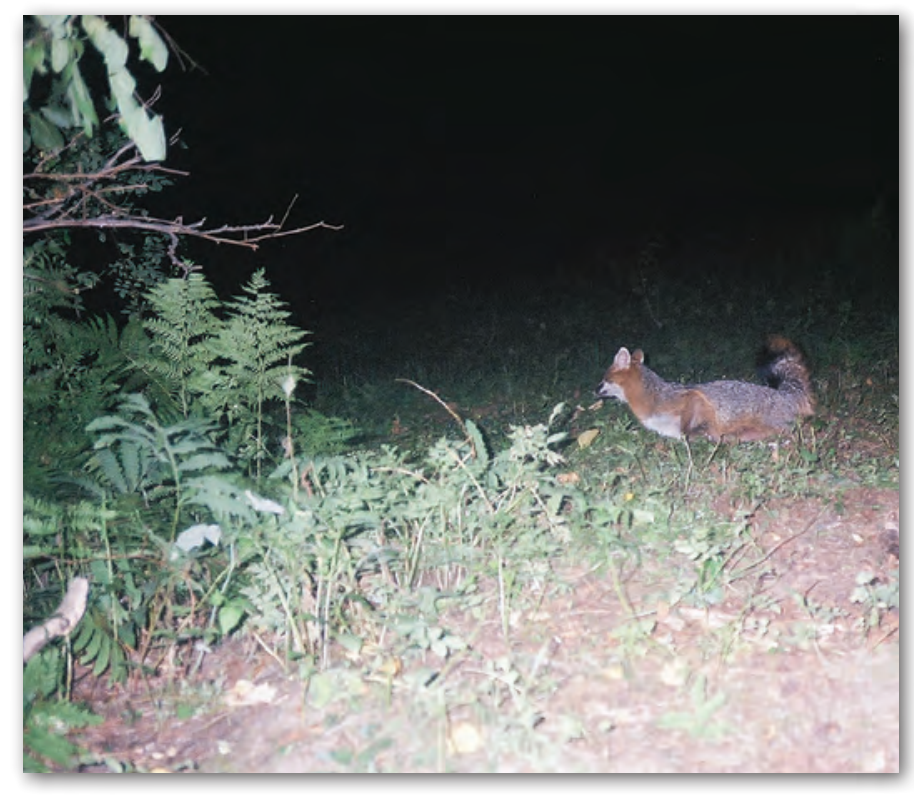


Table 22. Indirect measure (IM) and trap station numbers, community type, GPS locations of the camera at IM stations and beginning of the Longworth trap lines, orientation of IM stations, and bearing of trap lines at Minute Man National Historical Park.

\begin{tabular}{|c|c|c|c|c|c|}
\hline $\begin{array}{l}\text { Station } \\
\text { number }\end{array}$ & Station type & Community type & UTM $X^{a}$ & UTM Ya & $\begin{array}{c}\text { Orientation/ } \\
\text { bearing }^{\mathrm{b}}\end{array}$ \\
\hline 1 & Trap & wetland & 306769 & 4704430 & $160^{\circ}$ \\
\hline 5 & Trap & wetland & 310552 & 4702759 & $30^{\circ}$ \\
\hline 9 & IM & mixed deciduous-conifer & 313015 & 4702019 & E-W \\
\hline 13 & IM & wetland & 309594 & 4703678 & $\mathrm{~N}-\mathrm{S}$ \\
\hline 17 & Trap & mixed deciduous-conifer & 314255 & 4701924 & $160^{\circ}$ \\
\hline 21 & IM & scrub-shrub & 310014 & 4702595 & E-W \\
\hline 30 & IM & deciduous & 313808 & 4702051 & E-W \\
\hline 33 & IM & deciduous & 307039 & 4704502 & $\mathrm{~N}-\mathrm{S}$ \\
\hline 37 & IM & mixed deciduous-conifer & 310869 & 4702584 & $\mathrm{~N}-\mathrm{S}$ \\
\hline 41 & Trap & mixed deciduous-conifer & 310910 & 4702769 & $45^{\circ}$ \\
\hline 49 & Trap & conifer & 309574 & 4702702 & $45^{\circ}$ \\
\hline 51 & IM & conifer & 314242 & 4702055 & $\mathrm{~N}-\mathrm{S}$ \\
\hline 53 & Trap & conifer & 311346 & 4702855 & $225^{\circ}$ \\
\hline 55 & IM & mixed deciduous-conifer & 313104 & 4702348 & $\mathrm{~N}-\mathrm{S}$ \\
\hline 58 & Trap & deciduous & 307049 & 4704468 & $40^{\circ}$ \\
\hline 62 & Trap & deciduous & 311786 & 4702483 & $180^{\circ}$ \\
\hline 66 & IM & wetland & 310304 & 4702924 & $\mathrm{~N}-\mathrm{S}$ \\
\hline 70 & IM & deciduous & 309530 & 4703376 & E-W \\
\hline 74 & Trap & field & 313981 & 4701927 & $0^{\circ}$ \\
\hline 78 & IM & field & 306693 & 4704911 & E-W \\
\hline 82 & IM & field & 309520 & 4703044 & $\mathrm{~N}-\mathrm{S}$ \\
\hline 86 & Trap & field & 309777 & 4703342 & $0^{\circ}$ \\
\hline
\end{tabular}

${ }^{a}$ Universal Transverse Mercator Zone 19; datum, North American Datum 1983; units, meters.

${ }^{\mathrm{b}}$ The orientation of the trackplates relative to the cameras in the indirect measure station or the bearing of the trap lines.

The highest diversity of small mammal species documented during this project was also at MIMA. The Whitefooted Mouse (Peromyscus leucopus) was captured in several different communities and in substantial numbers (table 25). Individuals having characteristics shared by both Deer (P. maniculatus) and White-footed Mouse were captured frequently and at many stations. The ranges of these two species overlap over most of the northeastern United States; the White-footed Mouse is absent only from northern Maine and the Deer Mouse is absent only from the strip of coast between Rhode Island and Maryland (Whitaker and Hamilton, 1998). Hybridization could explain the characteristics of intermediate morphology encountered in this study (Kamler and others, 1998) where the two species overlap (including all of Massachusetts). The Northern Short-tailed Shrew (Blarina brevicauda) and Meadow Vole (Microtus pennsylvanicus) also were detected frequently; the Northern Short-tailed Shrew was found in nearly all community types and Meadow Voles were found only in fields and wetlands (table 23).

Species diversity varied among community types, with 7 to 16 species detected (table 23), but no geographic area within the park appeared to be more diverse than any other (figures 20-21). Mixed forest, fields, and deciduous forest community types (in decreasing order) had the most species detected. One sampling station in a field adjacent to the North Bridge visitor center (\#78) stood out for its high species 

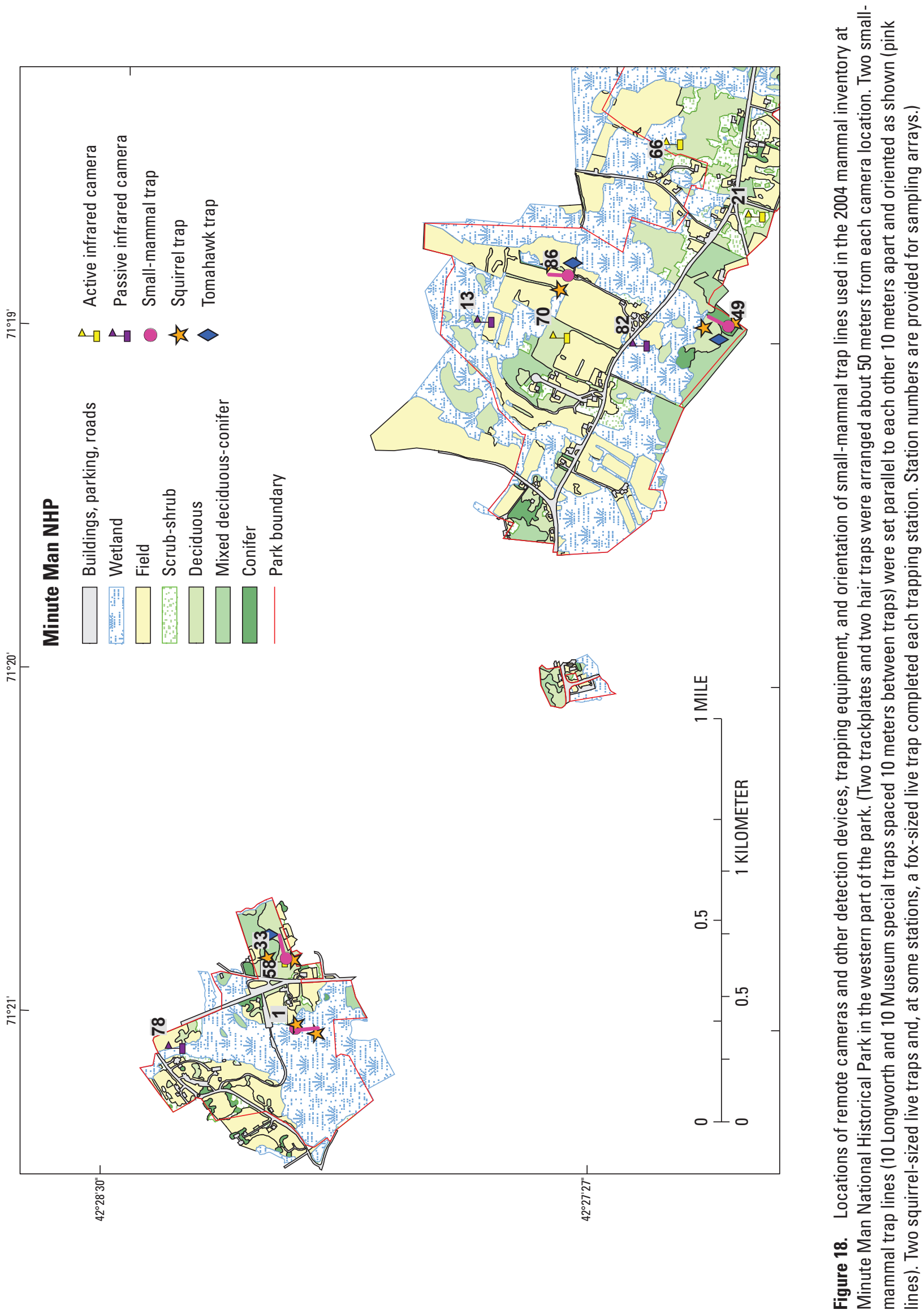


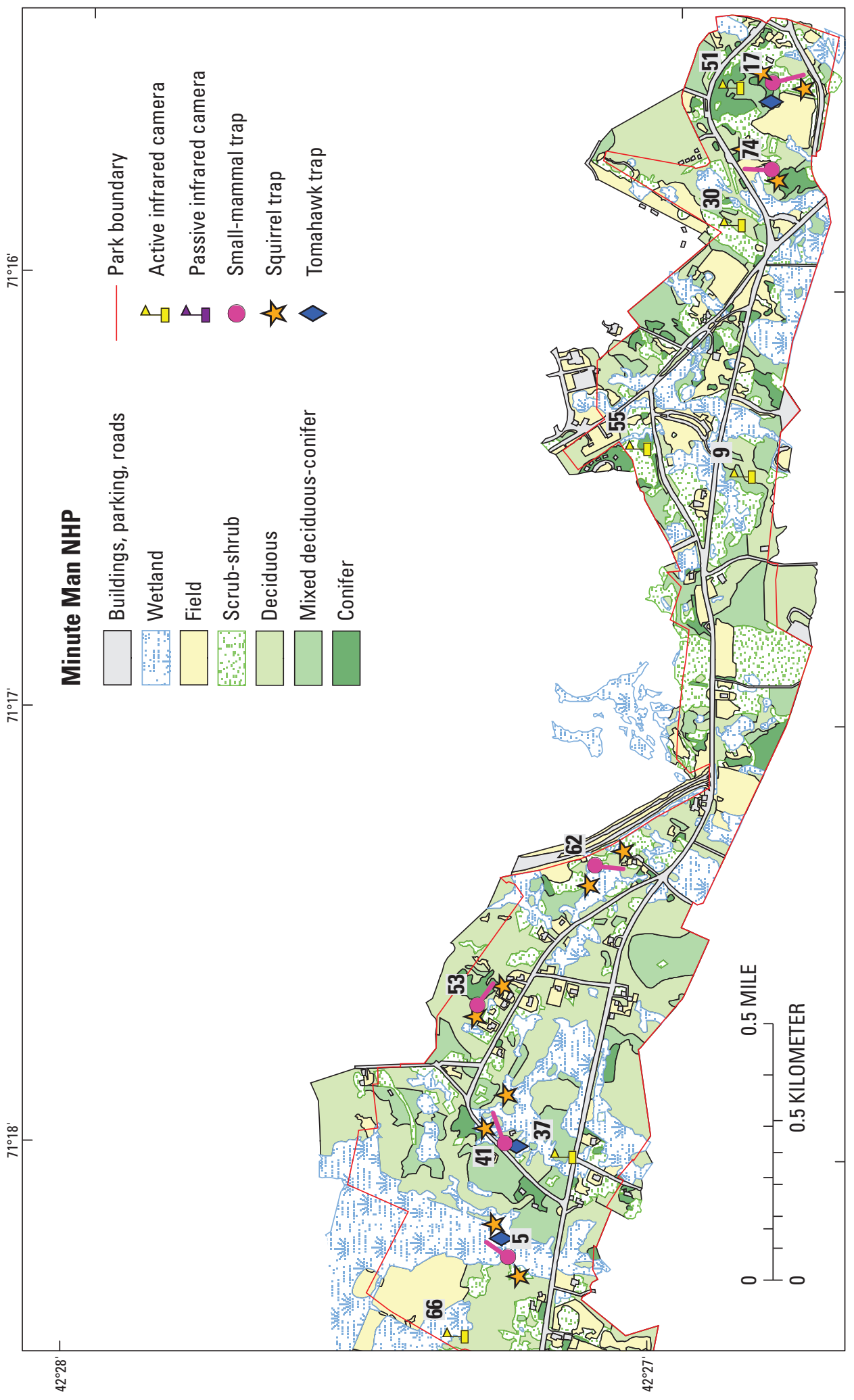

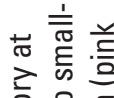

紊登

这市

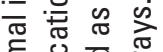

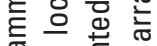

范 $\frac{\pi}{\omega}$.

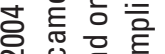

๑ 듀

声专

등

$\Phi$ 인

के क्षे

을음

흔휴

产苛 吉

흥을

ॠ 홍

言

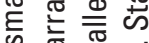

屯。

든 严曹

西

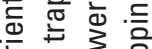

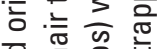

등 흔

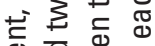

峁完㐫

言要

d $\frac{\pi}{2}$ ह

을 웡

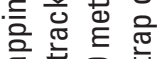

뜬 으

s.

웡

힝 की

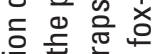

응

d

흔 응 응

Ф

艺选密

完

\%

풍. 으응

틍 흥

을 응

तु

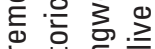

论 糎

는 은 호

은 등 क

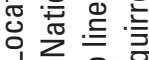

기응

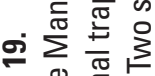

인

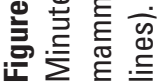


Table 23. Community type associations of mammals detected at Minute Man National Historical Park by indirect measure sampling, trapping, and observation.

[Community type associations are based on vegetation community descriptions of each sampling location. C, camera; TP, trackplate; TR, trapping; X, species observed for which we have records; -, not detected]

\begin{tabular}{|c|c|c|c|c|c|c|c|}
\hline Species detected & \multicolumn{6}{|c|}{ Community type } & Observed \\
\hline Virginia Opossum & $\mathrm{TP}$ & $\mathrm{C}, \mathrm{TP}$ & $\mathrm{C}, \mathrm{TP}$ & $\mathrm{C}, \mathrm{TP}, \mathrm{TR}$ & $\mathrm{C}, \mathrm{TP}$ & $\mathrm{C}, \mathrm{TP}$ & - \\
\hline Masked Shrew & - & - & - & - & - & TR & - \\
\hline Eastern or New England Cottontail & - & - & $\mathrm{C}$ & - & - & - & - \\
\hline Eastern Chipmunk & - & $\mathrm{TP}$ & $\mathrm{C}, \mathrm{TP}$ & $\mathrm{TP}$ & - & TR & - \\
\hline Gray Squirrel & - & - & $\mathrm{C}, \mathrm{TP}$ & TR & - & - & - \\
\hline Red Squirrel & - & $\mathrm{TP}$ & - & TP & $\mathrm{TP}$ & TR & - \\
\hline Rat spp. or Eastern Chipmunk & - & $\mathrm{TP}$ & $\mathrm{TP}$ & - & $\mathrm{TP}$ & - & - \\
\hline Squirrel spp. & - & - & $\mathrm{TP}$ & - & - & - & - \\
\hline Woodchuck & - & $\mathrm{TP}$ & - & - & - & - & $\mathrm{X}$ \\
\hline White-footed Mouse & TR & TR & TR & TR & - & TR & - \\
\hline Deer or White-footed Mouse & TR & $\mathrm{TR}$ & TR & TR & - & TR & - \\
\hline Meadow Vole & - & - & TR & - & - & TR & - \\
\hline Woodland Vole & - & - & - & TR & - & - & - \\
\hline Red-backed Vole & - & $\mathrm{TR}$ & - & TR & - & TR & - \\
\hline Red Fox & - & $\mathrm{C}$ & $\mathrm{C}$ & $\mathrm{C}$ & - & - & - \\
\hline Raccoon & $\mathrm{C}, \mathrm{TP}$ & $\mathrm{C}, \mathrm{TP}$ & $\mathrm{C}, \mathrm{TP}$ & $\mathrm{C}, \mathrm{TP}, \mathrm{TR}$ & $\mathrm{C}, \mathrm{TP}$ & $\mathrm{C}, \mathrm{TP}, \mathrm{TR}$ & - \\
\hline Ermine & - & - & - & $\mathrm{TP}$ & - & - & - \\
\hline Fisher & $\mathrm{C}, \mathrm{TP}$ & $\mathrm{C}$ & $\mathrm{TP}$ & $\mathrm{C}, \mathrm{TP}$ & $\mathrm{C}$ & $\mathrm{C}$ & $\mathrm{X}$ \\
\hline Long-tailed Weasel & - & $\mathrm{TP}$ & - & - & - & - & - \\
\hline Long-tailed Weasel/Ermine & - & - & - & $\mathrm{TP}$ & $\mathrm{TP}$ & - & - \\
\hline Long-tailed Weasel/Mink & - & - & - & $\mathrm{TP}$ & - & - & - \\
\hline Striped Skunk & - & $\mathrm{C}, \mathrm{TP}, \mathrm{TR}$ & $\mathrm{C}, \mathrm{TP}$ & - & - & - & - \\
\hline Domestic Cat & - & - & $\mathrm{C}, \mathrm{TP}$ & - & $\mathrm{C}$ & - & - \\
\hline White-tailed Deer & - & - & $\mathrm{C}$ & - & - & - & - \\
\hline Total species detected $^{\mathrm{a}}$ & 7 & 14 & 15 & 16 & 10 & 10 & 4 \\
\hline
\end{tabular}

${ }^{a}$ Totals exclude generic counts unless no other species in that group were detected (for example, Shrew spp. would be counted if no other specific shrew was detected). 
Table 24. Mammal species detection rates and site occupancy at 12 indirect measure stations at Minute Man National Historical Park during two sampling sessions in 2004.

$[-$, species not detected]

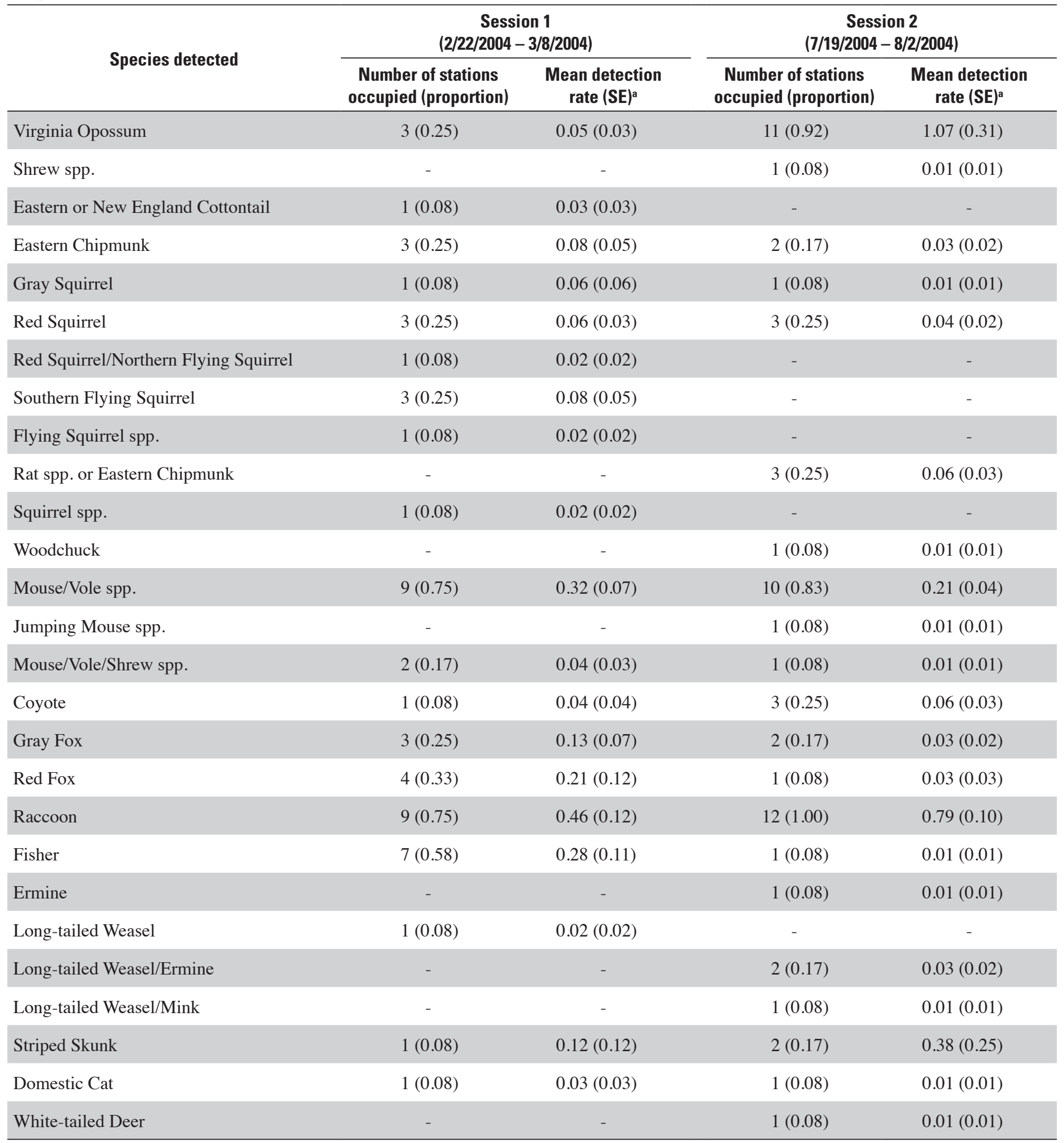

${ }^{a}$ The mean rate of detection and standard error over all stations including those stations where the species was not detected (detection rate $=0$ ). Species detection rates were calculated for each station by dividing the total number of individual species detections for all checks at a station (camera and trackplate only) by the number of checks made at that station. SE, the standard error of this mean. 
Table 25. Mammal capture rates and site occupancy for 10 trapping stations (6 with fox-sized live traps) at Minute Man National Historical Park during sampling session 2 $(7 / 19 / 2004-8 / 2 / 2004)$.

\begin{tabular}{|c|c|c|c|}
\hline Species Detected & $\begin{array}{c}\text { Number } \\
\text { of new } \\
\text { captures }\end{array}$ & $\begin{array}{c}\text { Number of } \\
\text { stations } \\
\text { occupied } \\
\text { (proportion) }^{\mathrm{a}}\end{array}$ & $\begin{array}{c}\text { Mean rate } \\
\text { of new } \\
\text { individuals } \\
\text { captured (SE) }\end{array}$ \\
\hline Virginia Opossum & 1 & $1(0.17)$ & $0.03(0.03)$ \\
\hline $\begin{array}{l}\text { Northern Short-tailed } \\
\text { Shrew }\end{array}$ & 15 & $7(0.70)$ & $0.32(0.09)$ \\
\hline Masked Shrew & 1 & $1(0.10)$ & $0.02(0.02)$ \\
\hline Shrew spp. & 4 & $3(0.30)$ & $0.08(0.05)$ \\
\hline Eastern Chipmunk & 8 & $1(0.10)$ & $0.16(0.16)$ \\
\hline Gray Squirrel & 1 & $1(0.10)$ & $0.02(0.02)$ \\
\hline Red Squirrel & 1 & $1(0.10)$ & $0.02(0.02)$ \\
\hline White-footed Mouse & 75 & $10(1.00)$ & $1.60(0.40)$ \\
\hline $\begin{array}{l}\text { Deer or White-footed } \\
\text { Mouse }\end{array}$ & 29 & $7(0.70)$ & $0.61(0.18)$ \\
\hline Meadow Vole & 14 & $3(0.30)$ & $0.30(0.20)$ \\
\hline Woodland Vole & 3 & $2(0.20)$ & $0.06(0.04)$ \\
\hline Red-backed Vole & 6 & $3(0.30)$ & $0.13(0.07)$ \\
\hline $\begin{array}{l}\text { Meadow Jumping } \\
\text { Mouse }\end{array}$ & 3 & $1(0.10)$ & $0.06(0.06)$ \\
\hline Raccoon & 2 & $2(0.33)$ & $0.07(0.03)$ \\
\hline Striped Skunk & 1 & $1(0.17)$ & $0.03(0.03)$ \\
\hline
\end{tabular}

${ }^{a}$ Small-mammal and squirrel-sized live traps were placed at all 10 stations whereas fox-sized live traps were set at only 6 ; therefore, the number of stations at which medium-sized mammals (Domestic Cat, Raccoon, Striped Skunk, Virginia Opossum) could be captured was reduced to 6 for individual species for each night of sampling.

${ }^{\mathrm{b}}$ Rates were calculated for each station by dividing the total number of new individuals captured (per species) by the number of nights that traps were operational. SE, standard error of the mean.

diversity (11) and number of detections (61) - two more species than at other stations, and more than double the number of detections. The high diversity at this station is surprising given its proximity to roads and areas of high housing density. However, this site is connected to the 1,500-ha Great Meadows National Wildlife Refuge (U.S. Fish and Wildlife Service, 2005a) by the Concord River, a natural corridor flowing north from MIMA through the refuge.

\section{Species Expected but Not Detected}

We did not detect any moles at MIMA. These animals are primarily fossorial, preferring to tunnel underground for food, although the Star-nosed Mole (Condylura cristata) also makes use of wet areas such as wet meadows, swamps, and streams to feed (Whitaker and Hamilton, 1998). Moles are not routinely captured in small mammal traps and we did not expect to detect them in this study unless we observed them directly or found evidence of the mounded tunnels they leave in soft soil. We expect that both Hairy-tailed (Parascalops breweri) and Star-nosed Moles occur at MIMA; this is corroborated by local voucher specimens recorded for these species (table 26). Eastern Moles (Scalopus aquaticus) occur at the northern edge of their range in this area and we did not expect to find them.

We did not detect Mink but expect that this species occurs along the Concord River and along other streams within the park. Other local surveys set out remote cameras in July and August of 2001 that recorded Mink within the newly established Assabet River National Wildlife Refuge (southwest of MIMA) (Wildlife Trails Education Project, 2002). The Assabet River converges with the Sudbury River in Concord and would make an ideal corridor for this semi-aquatic species to reach MIMA. We recorded one set of tracks that were of a size intermediate between those of the Mink and the Long-tailed Weasel. When possible, Mink stay close to water (Whitaker and Hamilton, 1998) and IM sampling may not have been close enough to the Concord River or other suitable waters to detect this species. Several voucher specimens have been collected from this area (table 26), substantiating that this species does occur here.

We did not detect Beaver (Castor canadensis) at MIMA during this study, but Beaver activity was recently reported near the North Bridge. Several trees have been damaged by beavers actively trying to fell trees near the bridge (Christopher Davis, National Park Service, oral commun., 2005). Beavers are not common in the park, but they are present, especially along the Concord River.

River Otters (Lontra canadensis) are found along streams throughout Massachusetts (Cardoza and others, 1999). Photodocumentation of River Otters has been achieved at nearby Assabet National Wildlife Refuge (Wildlife Trails Education Project, 2002). Given its highly aquatic habits, this species is a likely inhabitant of the Concord River as well. Although they are rarely observed, their slides are obvious and easy to detect in the winter. The Concord River would be the most likely place to find River Otter and detecting their slides in winter would confirm the presence of this species.

\section{Endangered and Threatened Species}

We did not detect any species that are listed as state or federally threatened, endangered, or of special concern for Massachusetts (Massachusetts Department of Fisheries and Wildlife, 2003). The State of Massachusetts lists the Indiana Bat (Myotis sodalis) as endangered and the Small-footed 
Myotis (M. leibii), Water Shrew (Sorex palustris), Rock (Long-tailed) Shrew (S. dispar), and Southern Bog Lemming (Synaptomys cooperi) as species of special concern.

The Indiana Bat is listed as both state and federally endangered in Massachusetts (Massachusetts Department of Fisheries and Wildlife, 2003). This species has been reported from Berkshire, Hampden, and Worcester Counties, but the species probably is extirpated from the entire state (Cardoza and others, 1999). Maternity roosts are found under the loose bark of trees and this species has been known to use elms, oaks, hickories, Cottonwood (Populus deltoides), Silver Maple (Acer saccharinum), and Green Ash (Fraxinus pennsylvanica) (Kurta and others, 1993), especially in riparian areas (Thomson, 1982). Some of these trees occur at MIMA and may provide appropriate summer roosts for Indiana Bat. However, we do not have any evidence that this species occurs in the park.

The Small-footed Myotis is considered a bat species of special concern in Massachusetts (Massachusetts Department of Fisheries and Wildlife, 2003). The species is one of the rarest bats in North America and is found in mountainous regions throughout the Northeast, including Massachusetts (Best and Jennings, 1997). They hibernate in caves or mines, but little is known about their summer habits (Whitaker and Hamilton, 1998). Given the lack of information about this species, it is not possible to state whether this species currently occurs in the park.

The distribution of the Water Shrew in Massachusetts is listed as Hampshire and Worcester Counties (Cardoza and others, 1999). Water Shrews are semi-aquatic, preferring wetlands along streams, lakes, and ponds (Godin, 1977; Whitaker and Hamilton, 1998). Given the close proximity of MIMA to Worcester County, this species may occur in the park. The species is more numerous than collections typically indicate (Whitaker and Hamilton, 1998), making its presence in MIMA possible, despite the lack of captures and museum specimens.
Rock Shrews are reported in far western Massachusetts (Berkshire County) only (Cardoza and others, 1999). This species is found in upland areas, especially among rocks and along mountain streams (Whitaker and Hamilton, 1998). This species is not expected to occur in the park.

The Southern Bog Lemming occurs in a diverse array of habitats and is not restricted to sphagnum bogs, although most animals captured along the East Coast have been found in sphagnum bogs or heavy forest (Linzey, 1983). This species is colonial, nocturnal, and elusive, making it a difficult species to detect (Whitaker and Hamilton, 1998). This enigmatic rodent is reported in Franklin, Hampshire, and Worcester Counties, but probably occurs elsewhere in the state (Cardoza and others, 1999), perhaps including MIMA.

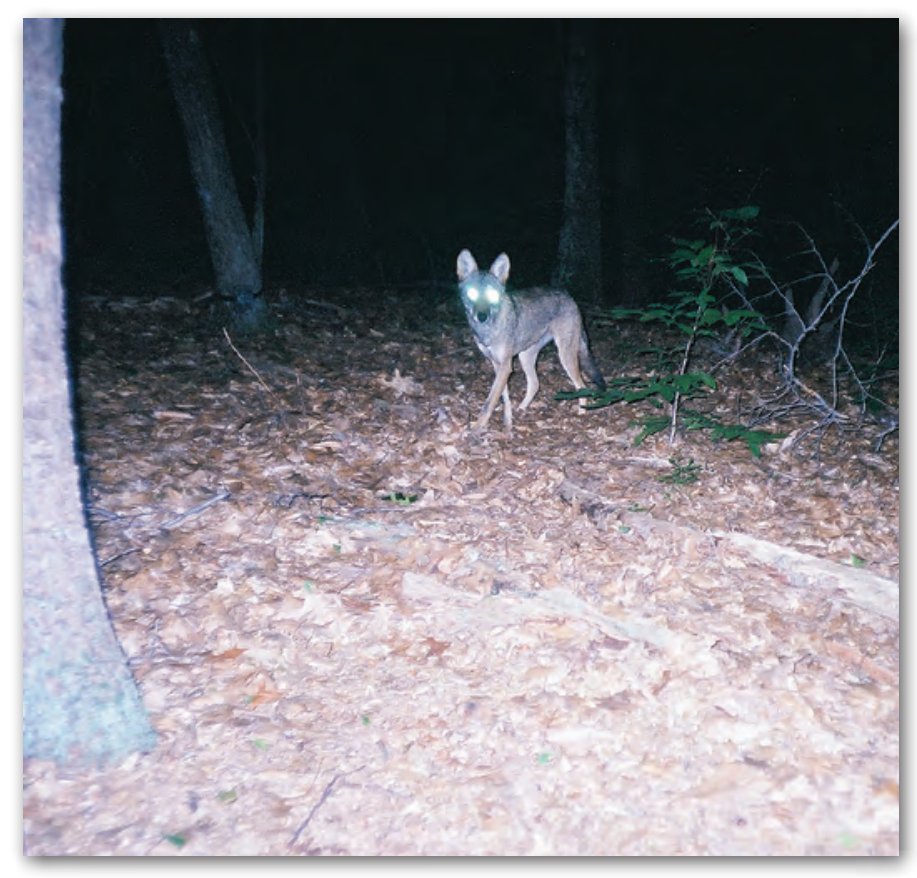




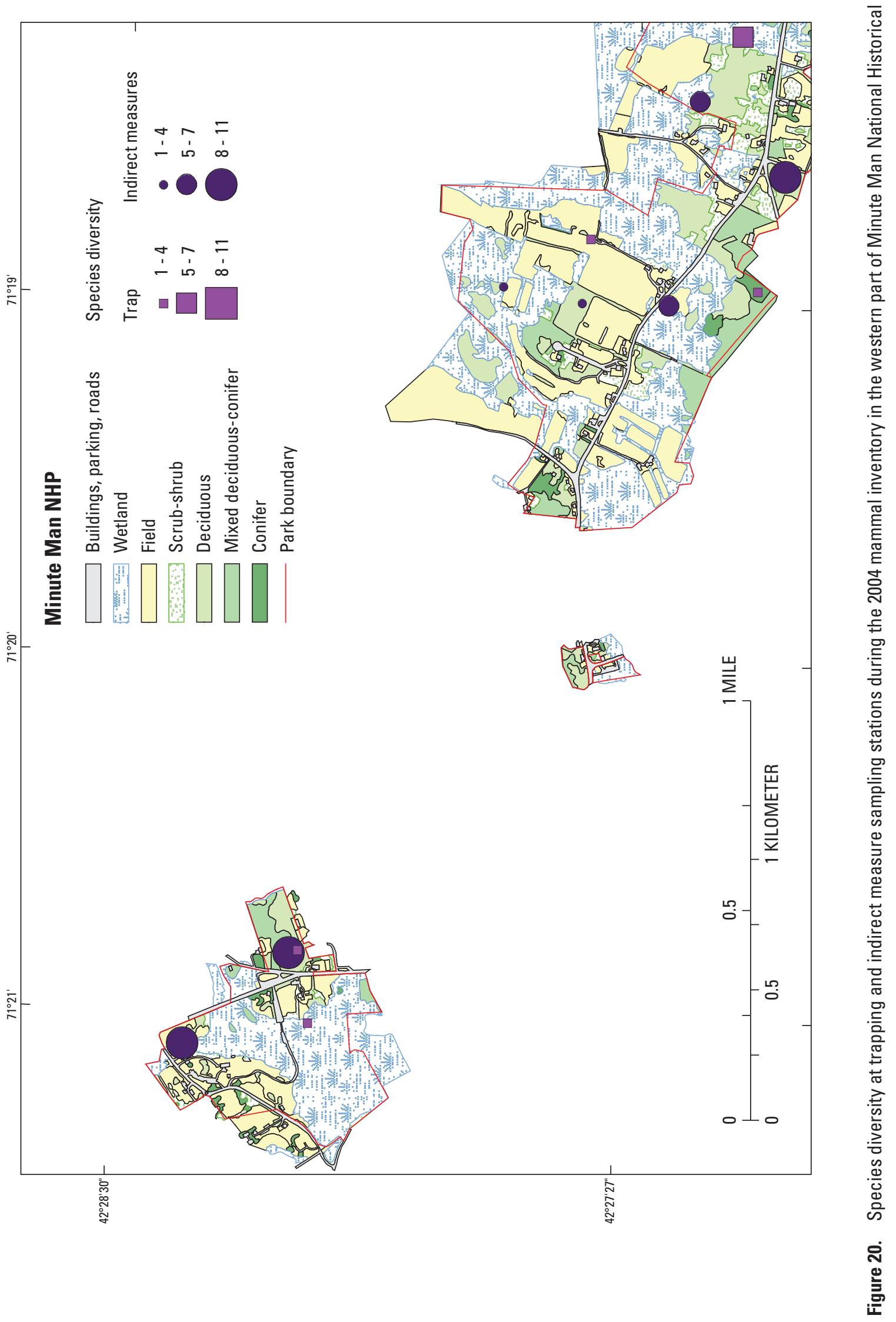




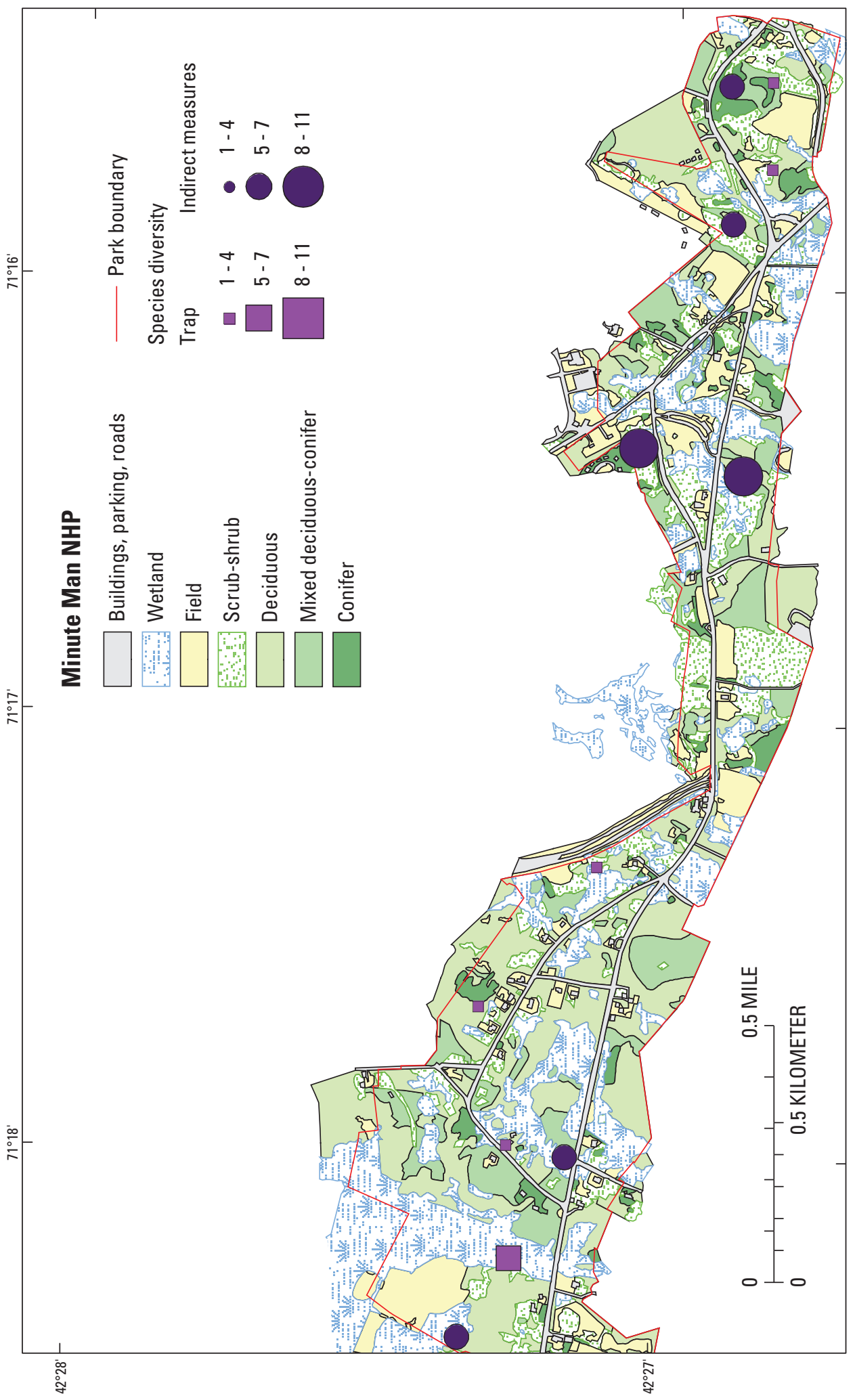

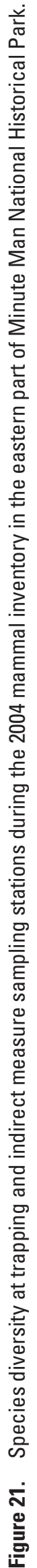


Table 26. Number of mammal specimens in museum collections and their proximity to Minute Man National Historical Park.

[Proximity-to-park codes: 1, collected within park boundaries; 2, collected in the town (Concord, Lincoln, Lexington, Mass.) the park is located in; 3, collected in the county (Middlesex) the park is located in. Institutions: AMNH, American Museum of Natural History; CM, Carnegie Museum of Natural History; CONN, University of Connecticut, EEB; CUMV, Cornell University Museum of Vertebrates; FMNH, Field Museum of Natural History; KUNHM, University of Kansas, Natural History Museum; MCZ, Harvard University, Museum of Comparative Zoology; MSB, Museum of Southwestern Biology; MVZ, University of California, Berkeley, Museum of Vertebrate Zoology; NUVC, Northeastern University Vertebrate Collection; TTU, Texas Tech University; UMMZ, University of Michigan Museum of Zoology; YPM, Yale University Peabody Museum of Natural History. -, no specimens]

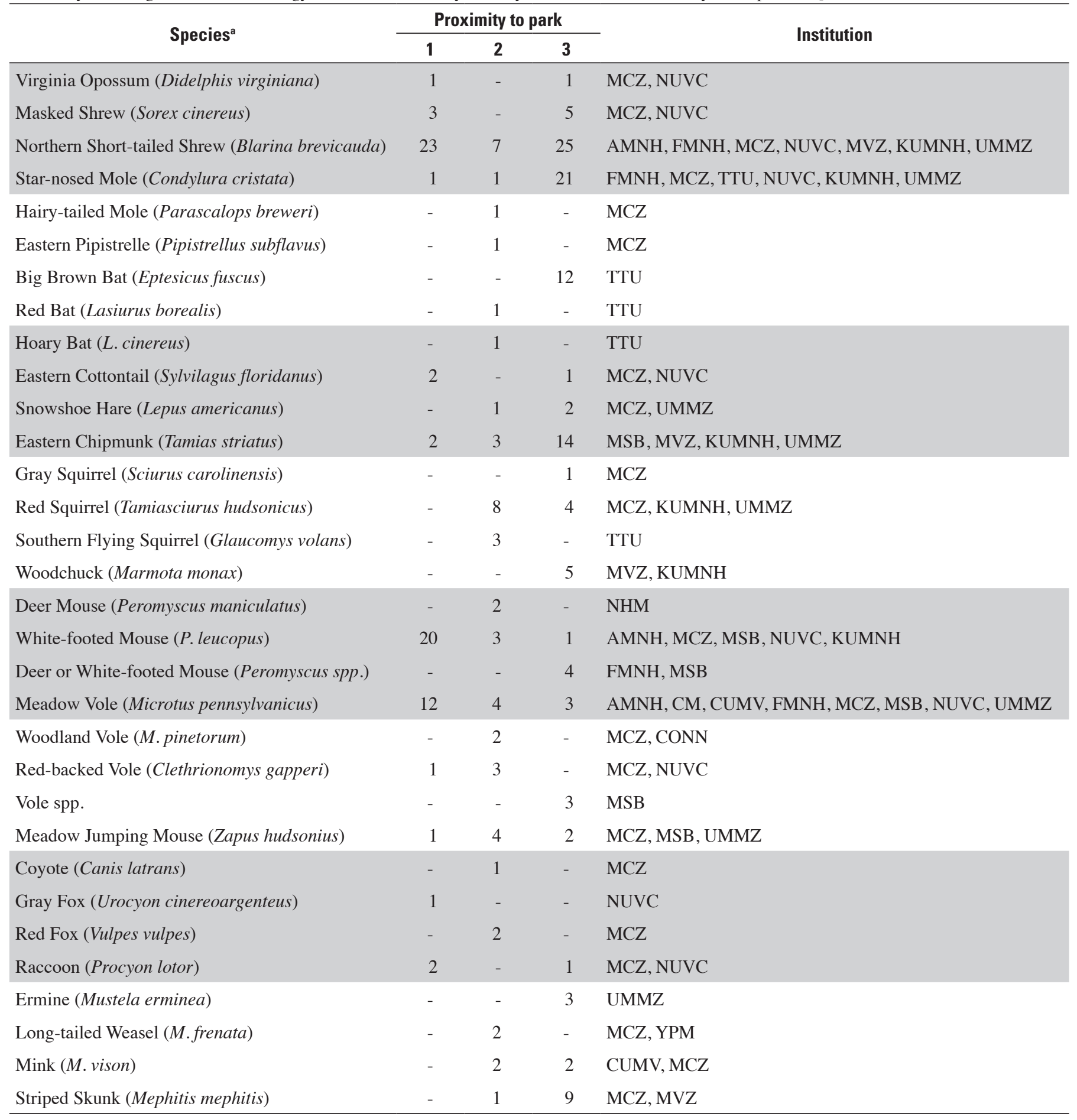

a Specimen data available through the National Park Service, NPSpecies database. For more information see: Gilbert and O'Connell, 2004; O’Connell and others, 2004; and A.F. O'Connell and A.T. Gilbert, unpublished data available at the USGS Patuxent Wildlife Research Center laboratory in Beltsville, Md.. 


\section{Saugus Iron Works National Historic Site (SAIR)}

\section{Background}

Saugus Iron Works National Historic Site (SAIR) is an historical iron works site dating from the early Colonial Period. The smallest park in the NETN at only 4 ha (Mitchell and others, 2006), the site is located north of Boston in suburban Saugus, Massachusetts. The Saugus River is the predominant natural feature and forms a large wetland bordering the site on the south. The remainder of the park consists of small strips of woodland fringing the wetland, landscaped grounds, and buildings.

\section{Prior Investigations}

No prior work on mammals has been conducted at SAIR.

\section{Sampling Stations}

Indirect measure sampling was conducted in February/ March and September/October of 2004 and trapping was conducted in September/October of 2004. We used four sampling stations (two IM and two trap) at SAIR. Initially we had generated a number of additional sampling locations, but the size of the park did not allow for adequate separation of sampling equipment. Also, because of wetlands, presence of historic structures, and high public visibility of most areas of the park, we chose sampling-station locations non-randomly rather than use the systematic sampling protocol established at other project parks. We placed equipment at stations that we believed would be most effective at detecting mammals and still provide security for the equipment (table 27; fig. 22).

\section{Survey Results}

Eight species were detected at SAIR: five during IM sampling, four during trapping, and four by observation (table 28). This is 17 percent of the potential number of mammal species that could occur in the park, excluding bats $(\mathrm{N}=48$, table 1$)$. Fencing and the small size of the park probably limited some species from using the area, thus reducing species diversity (fig. 23). Low species diversity may also be explained by the low number of traps at SAIR (even though this is a modest trap density compared to that at other study parks). During the winter, only Raccoons (Procyon lotor), Domestic Cats (Felis silvestris), and Virginia Opossums (Didelphis virginiana) were detected by IM sampling (table 29). Small rodents, Eastern Chipmunks, and Gray Squirrels were detected in the summer by IM sampling (table 29). Raccoons were the most frequently detected medium-sized mammal species during both winter and summer. Domestic Cats and Virginia Opossums were the next most often detected medium-sized mammals in winter and summer, respectively (table 29). Only three Northern Short-tailed Shrew (Blarina brevicauda), four White-footed Mouse (Peromyscus leucopus), and two unidentified Peromy- 
Table 27. Locations of sampling equipment used for the mammal inventory at Saugus Iron Works National Historic Site and the community type where equipment was located.

[The location and orientation of small mammal trap lines (Longworth and Museum Special traps) are given from the start of each trap line.]

\begin{tabular}{|c|c|c|c|c|c|}
\hline $\begin{array}{l}\text { Station } \\
\text { number }\end{array}$ & Sampling equipment & Community type & UTM Xa & UTM Ya & $\begin{array}{l}\text { Trap line } \\
\text { bearing }\end{array}$ \\
\hline \multirow{2}{*}{4} & Small mammal trap & wetland & 334912 & 4703735 & $160^{\circ}$ \\
\hline & Squirrel trap & landscaped & 334908 & 4703821 & \\
\hline \multirow{3}{*}{5} & Active infrared camera & deciduous & 334930 & 4703722 & \\
\hline & Trackplate & deciduous & 334934 & 4703680 & \\
\hline & Trackplate & wetland & 334909 & 4703776 & \\
\hline \multirow[b]{2}{*}{10} & Small mammal trap & wetland & 335006 & 4703776 & $180^{\circ}$ \\
\hline & Squirrel trap & deciduous & 335020 & 4703643 & \\
\hline \multirow{2}{*}{$23^{\mathrm{b}}$} & Trackplate & wetland & 334987 & 4703799 & \\
\hline & Trackplate & wetland & 335001 & 4703679 & \\
\hline
\end{tabular}

${ }^{a}$ Universal Transverse Mercator Zone 19; datum, North American Datum 1983; units, meters.

${ }^{\mathrm{b}}$ There was no camera at this station because of the threat of vandalism.

Table 28. Community type associations of mammals detected at Saugus Iron Works National Historic Site by indirect measure sampling, trapping, and observation.

[Community type associations are based on vegetation community descriptions of each sampling location. C, camera; TP, trackplate; TR, trapping; X, species observed for which we have records; -, not detected]

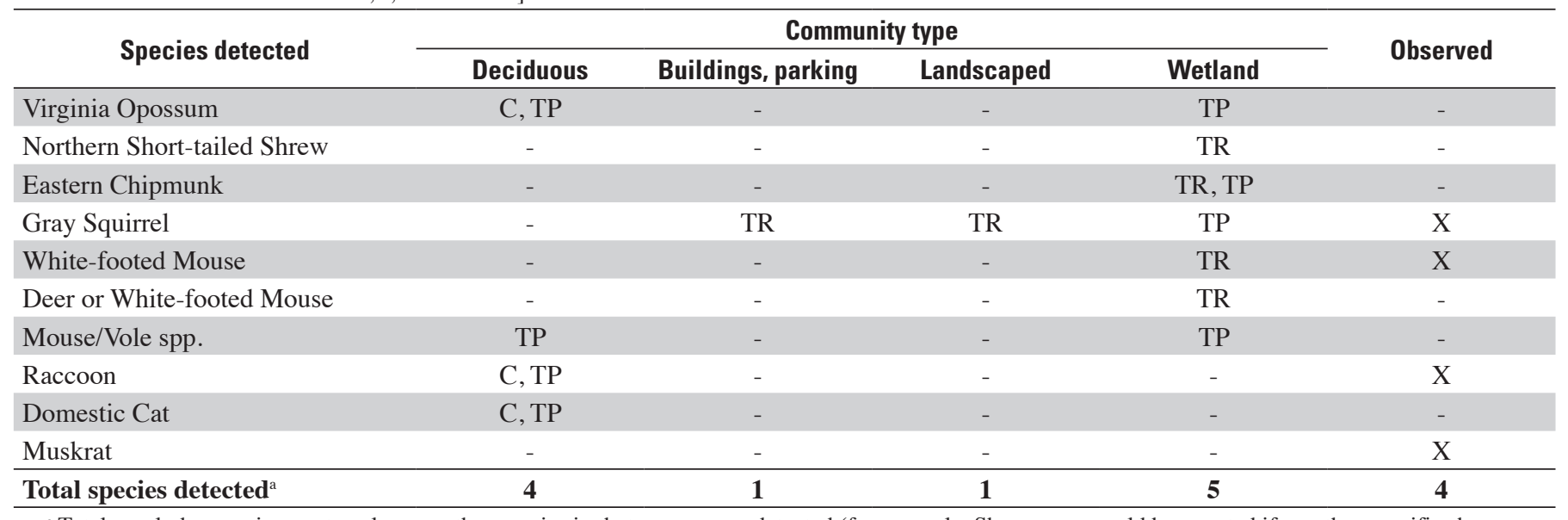

${ }^{a}$ Totals exclude generic counts unless no other species in that group were detected (for example, Shrew spp. would be counted if no other specific shrew was detected). 


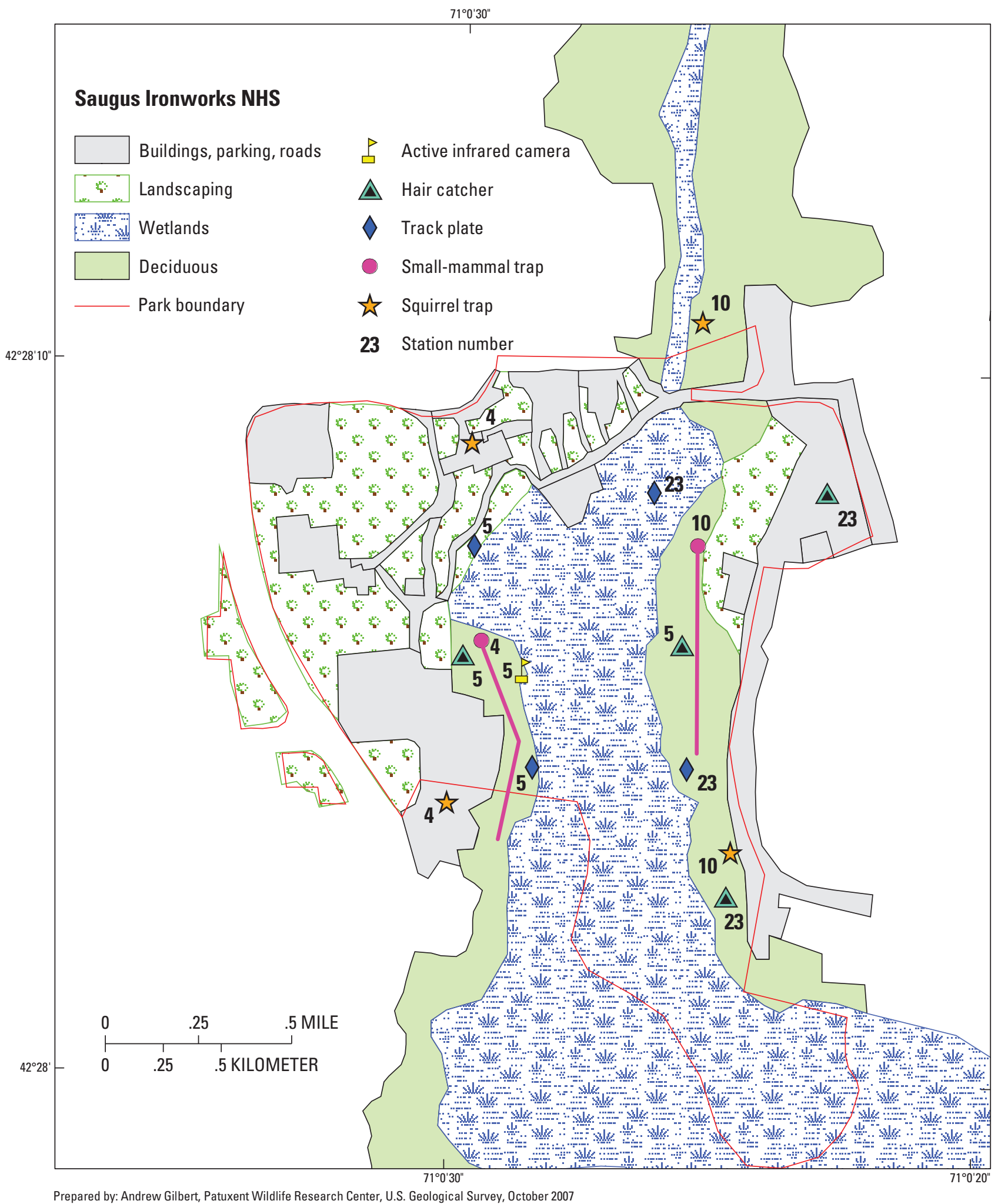

Figure 22. Locations of remote cameras and other detection devices, trapping equipment, and orientation of small-mammal trap lines used in the 2004 mammal inventory at Saugus Iron Works National Historic Site. (Indirect measure equipment was arranged differently than in other parks due to the small size of the park and limited areas in which to place equipment. Two small-mammal trap lines (10 Longworth and 10 Museum special traps spaced 10 meters between traps) were set parallel to each other 10 meters apart and oriented as shown (pink lines). Two squirrel-sized live traps completed each trapping station. Station numbers are provided for sampling arrays.) 


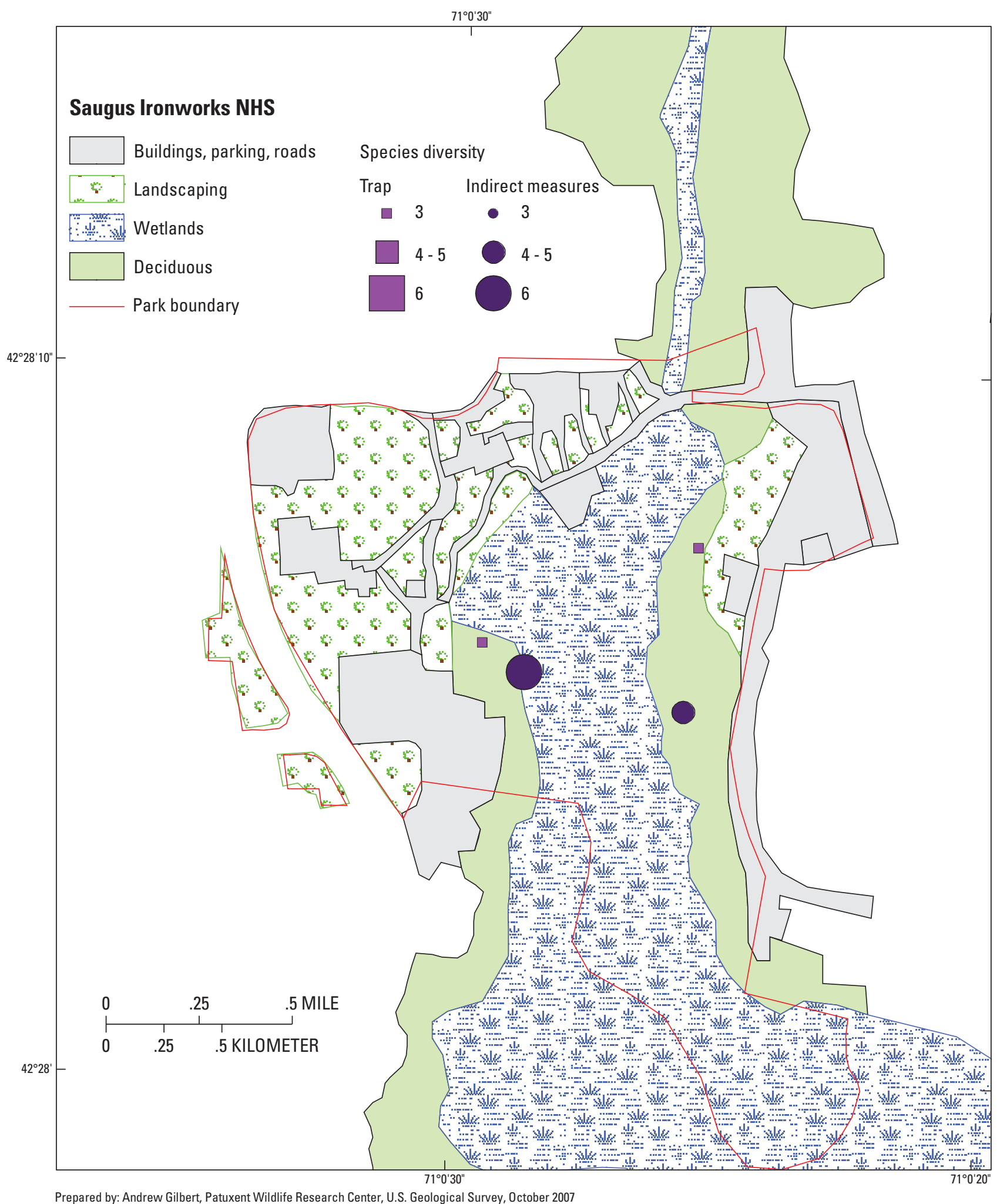

Figure 23. Species diversity at trapping and indirect measure sampling stations during the 2004 mammal inventory at Saugus Iron Works National Historic Site. 
Table 29. Mammal species detection rates and site occupancy at two indirect measure stations at Saugus Iron Works National Historic Site during two sampling sessions in 2004.

$[-$, species not detected $]$

\begin{tabular}{|c|c|c|c|c|}
\hline \multirow{2}{*}{ Species detected } & \multicolumn{2}{|c|}{$\begin{array}{c}\text { Session } 1 \\
(2 / 26 / 2004-3 / 10 / 2004)\end{array}$} & \multicolumn{2}{|c|}{$\begin{array}{c}\text { Session } 2 \\
(9 / 20 / 2004-10 / 4 / 2004)\end{array}$} \\
\hline & $\begin{array}{c}\text { Number of stations } \\
\text { occupied (proportion) }\end{array}$ & $\begin{array}{l}\text { Mean detection } \\
\text { rate (SE) }\end{array}$ & $\begin{array}{l}\text { Number of stations } \\
\text { occupied (proportion) }\end{array}$ & $\begin{array}{l}\text { Mean detection } \\
\text { rate (SE) }\end{array}$ \\
\hline Virginia Opossum & $1(0.50)$ & $0.21(0.21)$ & $2(1.00)$ & $0.50(0.30)$ \\
\hline Eastern Chipmunk & - & - & $2(1.00)$ & $0.30(0.10)$ \\
\hline Gray Squirrel & - & - & $1(0.50)$ & $0.10(0.10)$ \\
\hline Domestic Cat & $2(1.00)$ & $0.65(0.49)$ & $1(0.50)$ & $0.10(0.10)$ \\
\hline
\end{tabular}

${ }^{a}$ The mean rate of detection and standard error over all stations, including those stations where the species was not detected (detection rate $=0$ ). Species detection rates were calculated for each station by dividing the total number of individual species detections for all checks at a station (camera and trackplate only) by the number of checks made at that station. SE, standard error of the mean.

scus were captured (table 30). We did not set any fox-sized live traps and so no medium- or large-sized mammals were captured (table 30).

Station five showed the greatest diversity and number of detections; however, this station had a camera whereas the other IM station did not. Most of the large number of detections at this station were camera events $(\mathrm{N}=31)$ of which $>66$ percent were Raccoon visits; the rest were attributed to Virginia Opossums or Domestic Cats.

\section{Species Expected but Not Detected}

We did not detect any moles at SAIR. These animals are primarily fossorial, preferring to tunnel underground for food, although the Star-nosed Mole (Condylura cristata) also makes use of wet areas such as wet meadows, swamps, and streams to feed (Whitaker and Hamilton, 1998). Moles are not routinely captured in small-mammal traps, and we did not expect to detect moles in this study unless we observed them directly or found evidence of the mounded tunnels exposed in the soil. We expect that both Hairy-tailed (Parascalops breweri) and Star-nosed Moles occur at SAIR; a single voucher specimen has been recorded for the Star-nosed Mole (table 31). Eastern Moles (Scalopus aquaticus) occur at the northern edge of their range in this area.

There is ample evidence of Woodland Voles (Microtus pinetorum) occurring in the town of Saugus (table 31). Woodland Voles use a wide range of communities including deciduous woodlands and fields (Whitaker and Hamilton, 1998), and they may be found in the small groves of deciduous forest along the Saugus River in the park.

Woodchucks (Marmota monax) have been reported by park staff on the lawns at SAIR (Daniel Noon, National Park Service, oral commun., 2003), but this species was not observed or detected during this study. We do expect that this species feeds in grassy areas and may create burrows on park property.
Table 30. Mammal capture rates and site occupancy for two trapping stations at Saugus Iron Works National Historic Site during sampling session 2 (9/20/2004-10/4/2004).

\begin{tabular}{|c|c|c|c|}
\hline Species detected & $\begin{array}{c}\text { Number } \\
\text { of new } \\
\text { captures }\end{array}$ & $\begin{array}{c}\text { Number of } \\
\text { stations } \\
\text { occupied } \\
\text { (proportion) }\end{array}$ & $\begin{array}{c}\text { Mean rate } \\
\text { of new } \\
\text { individuals } \\
\text { captured (SE) }\end{array}$ \\
\hline $\begin{array}{l}\text { Northern Short-tailed } \\
\text { Shrew }\end{array}$ & 3 & $1(0.50)$ & $0.38(0.38)$ \\
\hline Eastern Chipmunk & 4 & $2(1.00)$ & $0.50(0.25)$ \\
\hline Gray Squirrel & 2 & $1(0.50)$ & $0.25(0.25)$ \\
\hline White-footed Mouse & 4 & $2(1.00)$ & $0.50(0.25)$ \\
\hline $\begin{array}{l}\text { Deer or White-footed } \\
\text { Mouse }\end{array}$ & 2 & $1(0.50)$ & $0.25(0.25)$ \\
\hline
\end{tabular}

We did not expect to detect Beaver (Castor canadensis) or River Otter (Lontra canadensis) during our short sampling periods at SAIR; however, we believe that both species use the Saugus River and at times can be found within the park boundary. In fact, both species have been reported in the park. River Otters were observed recently and evidence of Beavers also was apparent within the park (Daniel Noon, National Park Service, oral commun., 2003).

Larger animals such as the Red Fox (Vulpes vulpes), Gray Fox (Urocyon cinereoargenteus), Coyote (Canis latrans), and White-tailed Deer (Odocoileus virginianus) were not detected at the park during this survey. The small size of the park, fencing, and lack of adequate cover for these species make it unlikely that they spend much time in the park, occurring only as transients. 
Table 31. Number of mammal specimens in museum collections and their proximity to Saugus Iron Works National Historic Site.

[Proximity-to-park codes: 1, collected within park boundaries; 2, collected in the town (Saugus, Mass.) the park is located in; 3, collected in the county (Essex) the park is located in. Institutions. AMNH, American Museum of Natural History; CUMV, Cornell University Museum of Vertebrates; KUNHM, University of Kansas, Natural History Museum; MCZ, Harvard University, Museum of Comparative Zoology; UMMZ, University of Michigan Museum of Zoology. ,- no specimens]

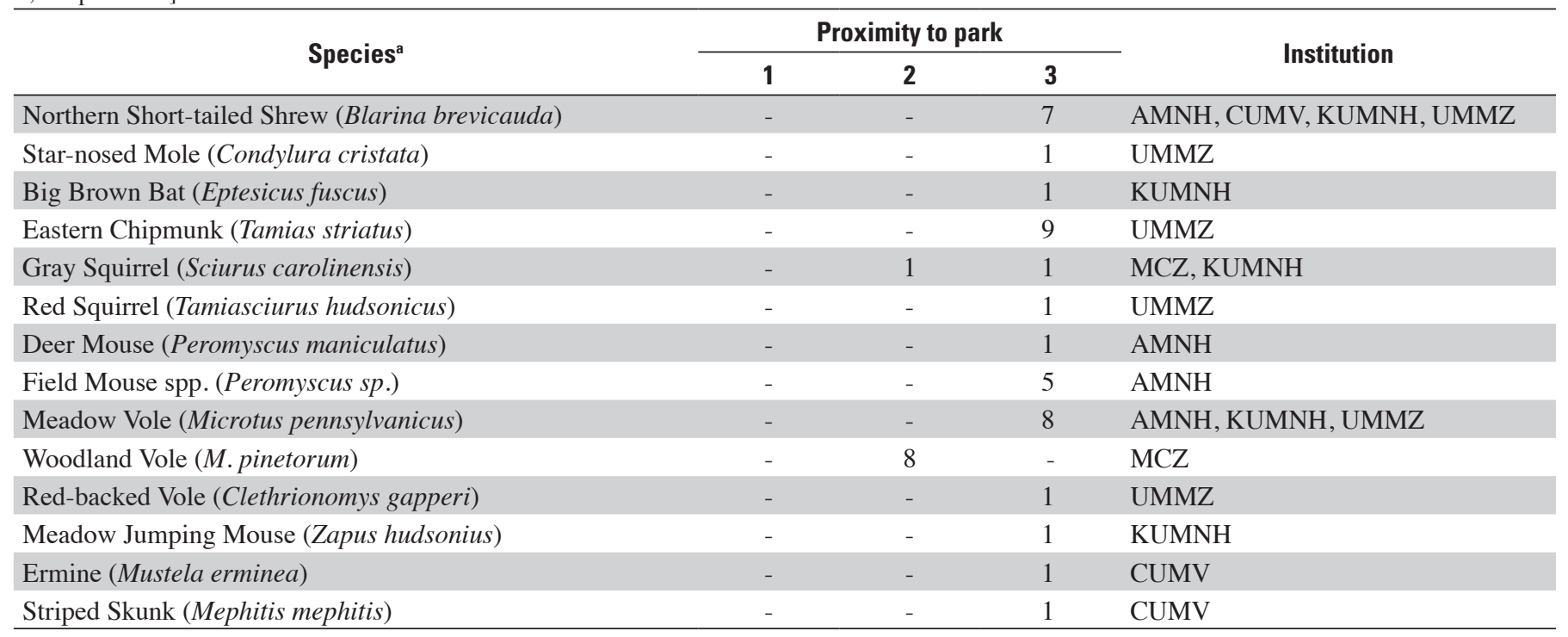

${ }^{a}$ Specimen data available through the National Park Service, NPSpecies database. For more information see: Gilbert and O'Connell, 2004; O'Connell and others, 2004; and A.F. O'Connell and A.T. Gilbert, unpublished data available at the USGS Patuxent Wildlife Research Center laboratory in Beltsville, Md.

\section{Endangered and Threatened Species}

We did not detect species that are listed as state or federally threatened, endangered, or of special concern. Massachusetts lists the Indiana Bat (Myotis sodalis) as endangered and the Small-footed Myotis (M. leibii), Water Shrew (Sorex palustris), Rock (Long-tailed) Shrew (S. dispar), and Southern Bog Lemming (Synaptomys cooperi) as species of special concern (Massachusetts Department of Fisheries and Wildlife, 2003).

The Indiana Bat (Myotis sodalis) is listed as both state and federally endangered (Massachusetts Department of Fisheries and Wildlife, 2003). This species has been reported in Berkshire, Hampden, and Worcester Counties, but probably is extirpated from the entire state (Cardoza and others, 1999). Maternity roosts are found under the loose bark of trees and this species has been known to use elms, oaks, hickories, Cottonwood (Populus deltoides), Silver Maple (Acer saccharinum), and Green Ash (Fraxinus pennsylvanica) (Kurta and others, 1993), especially in riparian areas (Thomson, 1982). Some of these trees are present at SAIR, and may provide appropriate summer roosts. We have no evidence that this species occurs in the park.

Small-footed Myotis (M. leibii) is a species of special concern in Massachusetts (Massachusetts Department of Fisheries and Wildlife, 2003). This bat is one of the rarest bats in North America and is found in mountainous regions throughout the Northeast, including Massachusetts (Best and Jennings, 1997). This species hibernates in caves or mines, but little is known about its summer habits (Whitaker and Hamilton, 1998). The presence of this species at SAIR is unlikely, but bats have been reported to roost in the blast furnace at SAIR (Daniel Noon, National Park Service, oral commun., 2003); however, species identifications were never made.

The known distribution of the Water Shrew is Hampshire and Worcester Counties (Cardoza and others, 1999). Water Shrews are semi-aquatic, preferring wetlands along streams, lakes, and ponds (Godin, 1977; Whitaker and Hamilton, 1998). The presence of the Saugus River and associated wetlands provide potential habitat for this species. This species may be far more numerous than collections indicate (Whitaker and Hamilton, 1998), and their presence at SAIR is possible despite the lack of captures and museum specimens.

Rock Shrews are reported as occurring in far western Massachusetts (Berkshire County) only (Cardoza and others, 1999). This species is found in upland areas, especially among rocks and along mountain streams (Whitaker and Hamilton 1998). This species is not expected to occur in SAIR.

The Southern Bog Lemming occurs in a diverse array of habitats and is not restricted to sphagnum bogs, although most animals captured along the East Coast have been found in sphagnum bogs or heavy forest (Linzey, 1983). Lemmings feed primarily on vegetation, particularly grasses and sedges (Linzey, 1983; Whitaker and Hamilton, 1998). This species may not be uncommon where it is found, but its colonial habits, nocturnal nature, and elusiveness make it a difficult species to detect (Whitaker and Hamilton, 1998). We do not know if this species occurs at SAIR, but if future surveys hope to document lemmings, they must focus on their natural history and habits. 


\section{Saint-Gaudens National Historic Site (SAGA)}

\section{Background}

Saint-Gaudens National Historic Site (SAGA) was the studio of famed sculptor Augustus Saint-Gaudens. Located in rural Cornish, New Hampshire, the park is a rugged landscape of steeply wooded ravines and old fields. Most of the 61 ha of the park is dominated by northern hardwoods-conifer mixed forest (Mitchell and others, 2006). Two streams pass through the park. Blow-Me-Up Brook flows west along the northern boundary and converges with Blow-Me-Down Brook along the western boundary. Blow-Me-Down Brook is dammed, forming Blow-Me-Down Pond, which drains into the Connecticut River to the south. Several trails traverse the park and provide easy access to all areas.

\section{Prior Investigations}

Two prior resource inventories were completed during the 1980s (Cronan and others, 1981; Cook, 1985). The earlier inventory was conducted in 1979-80 in support of an interpretive site description and mammals were trapped and observations recorded. Trapping was conducted during May and August 1980 in six community types: pine forest, mixed hardwoods re-growth, mowed field, riparian forest, upland hardwoods forest, and hardwood terrace. Five species were trapped: Deer Mouse (Peromyscus maniculatus), White-footed Mouse (P. leucopus), Woodland Jumping Mouse (Napaeozapus insignis), Red-backed Vole (Clethrionomys gapperi), and Chipmunk (Tamias striatus). Eight species were observed: White-tailed deer (Odocoileus virginianus), Raccoon (Procyon lotor), Little Brown Bat (Myotis lucifugus), Beaver (Castor canadensis), Gray Squirrel (Sciurus carolinensis), Muskrat (Ondatra zibethicus), Woodchuck (Marmota monax), and Red Squirrel (Tamiasciurus hudsonicus).
The latter inventory also employed trapping (snap and live traps) and observation techniques. Trapping was conducted in eight community types: upland hardwood forest, north-facing hardwood forest, south-facing hardwood forest, hemlock-hardwood forest, mixed coniferous forest, field, lawn, and wetland. Nine small mammal species were trapped: Smokey Shrew (Sorex fumeus), Masked Shrew (S. cinereus), Northern Short-tailed Shrew (Blarina brevicauda), Deer Mouse, White-footed Mouse, Red-backed Vole, Meadow Vole (Microtus pennsylvanicus), Meadow Jumping Mouse (Zapus hudsonius), and Woodland Jumping Mouse. Four larger mammals were also captured: Red Squirrel, Gray Squirrel, Raccoon, and Fisher (Martes pennanti). Other species were observed by Cook (1985) and park staff, including Hairytailed Mole (Parascalops breweri), Star-nosed Mole (Condylura cristata), Big Brown Bat (Eptesicus fuscus), Little Brown Bat, Eastern Chipmunk, Woodchuck, Muskrat, Porcupine (Erethizon dorsatum), Beaver, River Otter (Lontra canadensis), and White-tailed Deer.

A survey of bats was conducted during June and July 2002 in New Hampshire and included SAGA (Chenger, 2002). Mist net and harp traps were used for a total of 9 net-nights at SAGA over 2 days in July. Ultrasonic bat detectors also were used but the data were not analyzed. Forty-one captures were made at SAGA, including Big Brown Bat (Eptesicus fuscus), Little Brown Bat (Myotis lucifugus), and Northern Long-eared Bat (Myotis septentrionalis).

\section{Sampling Stations}

Indirect measure sampling was conducted in March and September 2004 and trapping was conducted in September 2004. We selected 21 sampling points (11 IM and 10 trap) in six community types prior to beginning field work (table 32 , fig. 24). Only two grid cells were assigned to the wetland stratum, resulting in 22 possible sampling points. We reduced trapping effort to 10 stations to ensure that we could adequately check all trapping equipment daily. 
Table 32. Indirect measure (IM) and trap station numbers, community type, GPS locations of the camera at IM stations and beginning of the Longworth trap lines, orientation of IM stations, and bearing of trap lines at Saint-Gaudens National Historic Site.

\begin{tabular}{cclccc}
\hline Station number & Station type & \multicolumn{1}{c}{ Community type } & UTM X & UTM Y & Orientation/bearing $^{\mathbf{b}}$ \\
\hline 1 & IM & riparian & 712356 & 4819935 & $\mathrm{E}-\mathrm{W}$ \\
4 & Trap & riparian & 712488 & 4819921 & $120^{\circ}$ \\
8 & Trap & riparian & 712331 & 4819955 & $270^{\circ}$ \\
10 & IM & riparian & 712767 & 4819906 & E-W $^{\circ}$ \\
14 & IM & wetland & 712176 & 4819470 & pond-edge $^{\text {c }}$ \\
15 & Trap & wetland & 712074 & 4819642 & $290^{\circ}$ \\
16 & Trap & field & 712629 & 4819708 & $315^{\circ}$ \\
18 & IM & field & 713049 & 4819603 & E-W \\
21 & IM & conifer & 712446 & 4819687 & E-W \\
22 & Trap & field & 712346 & 4819796 & $45^{\circ}$ \\
24 & IM & mixed deciduous-conifer & 712070 & 4819816 & N-S \\
26 & IM & mixed deciduous-conifer & 711992 & 4819768 & N-S \\
28 & Trap & deciduous & 712077 & 4819894 & $225^{\circ}$ \\
30 & Trap & mixed deciduous-conifer & 712646 & 4820025 & $275^{\circ}$ \\
32 & Trap & deciduous & 712166 & 4819712 & $275^{\circ}$ \\
33 & IM & mixed deciduous-conifer & 712194 & 4819618 & N-S \\
36 & IM & mixed deciduous-conifer & 712107 & 4818754 & E-W \\
38 & IM & conifer & 712295 & 4819327 & NW-SE \\
41 & Trap & mixed deciduous-conifer & 712295 & 4819659 & $45^{\circ}$ \\
45 & IM & mixed deciduous-conifer & 712220 & 4819139 & E-W \\
49 & Trap & conifer & 711899 & 4819905 & $45^{\circ}$ \\
\hline
\end{tabular}

a Universal Transverse Mercator Zone 18; datum, North American Datum 1983; units, meters.

b The orientation of trackplates relative to cameras in the IM station or the bearing of the trap lines.

${ }^{c}$ There was no camera at this station and equipment was oriented along the western boundary of Blow-Me-Down Pond so that the first hair trap was next to the old mill and a trackplate, hair trap, and another trackplate were arranged every $50 \mathrm{~m}$ along the pond shore. Location of this station is given at the mid-point of the setup.

${ }^{\mathrm{d}}$ Passive camera was used at this station during sampling session 1; active camera was used during sampling session 2.

\section{Survey Results}

Twenty-three species were detected at SAGA: 17 during indirect measure sampling, 10 by trapping, and 3 by observation (table 33). This is 46 percent of the potential number of mammal species that could occur in the park $(\mathrm{N}=50$, table 1), excluding bats. Fisher was the species most frequently detected during both sampling sessions (table 34). Fishers were widespread throughout the park, and were detected everywhere except in the deciduous community type (table 33). This species was detected in a previous inventory by Cook (1985). We also detected Coyotes (Canis latrans), Mink (Mustela vison), Long-tailed Weasel (M. frenata), and Ermine (M. erminea), none of which were detected by Cook (1985). We documented Black Bear (Ursus americanus) at SAGA with a single photograph, which was the only record of this species during this entire inventory.

We detected eight small-mammal species at SAGA (table 35). The White-footed Mouse was the species most commonly captured $(\mathrm{N}=37)$; similar results were reported by Cronan and others (1981). In contrast, the Northern Short- tailed Shrew was the most commonly captured species during Cook's (1985) survey (followed by the White-footed Mouse). We captured 11 Meadow Voles; their distribution was limited to fields. We did not capture any medium-sized or large mammals in the squirrel-sized or fox-sized live traps.

Species diversity varied among community types, with 3 to 12 species detected (table 33), but no geographic area in the park appeared to be more diverse than any other (fig. 25).

\section{Species Expected but Not Detected}

The Masked Shrew was the only species not captured in this inventory that was captured by Cook (1985). Shrews were likely not well documented in our work because we did not use pitfall traps, generally regarded as the preferred method for trapping shrews. (For a detailed explanation of this issue, please refer to the Trapping section on p. 13.) We believe that this species still occurs in the park.

We did not detect any moles at SAGA. These animals are primarily fossorial, preferring to tunnel underground for food, although the Star-nosed Mole also makes use of wet areas 


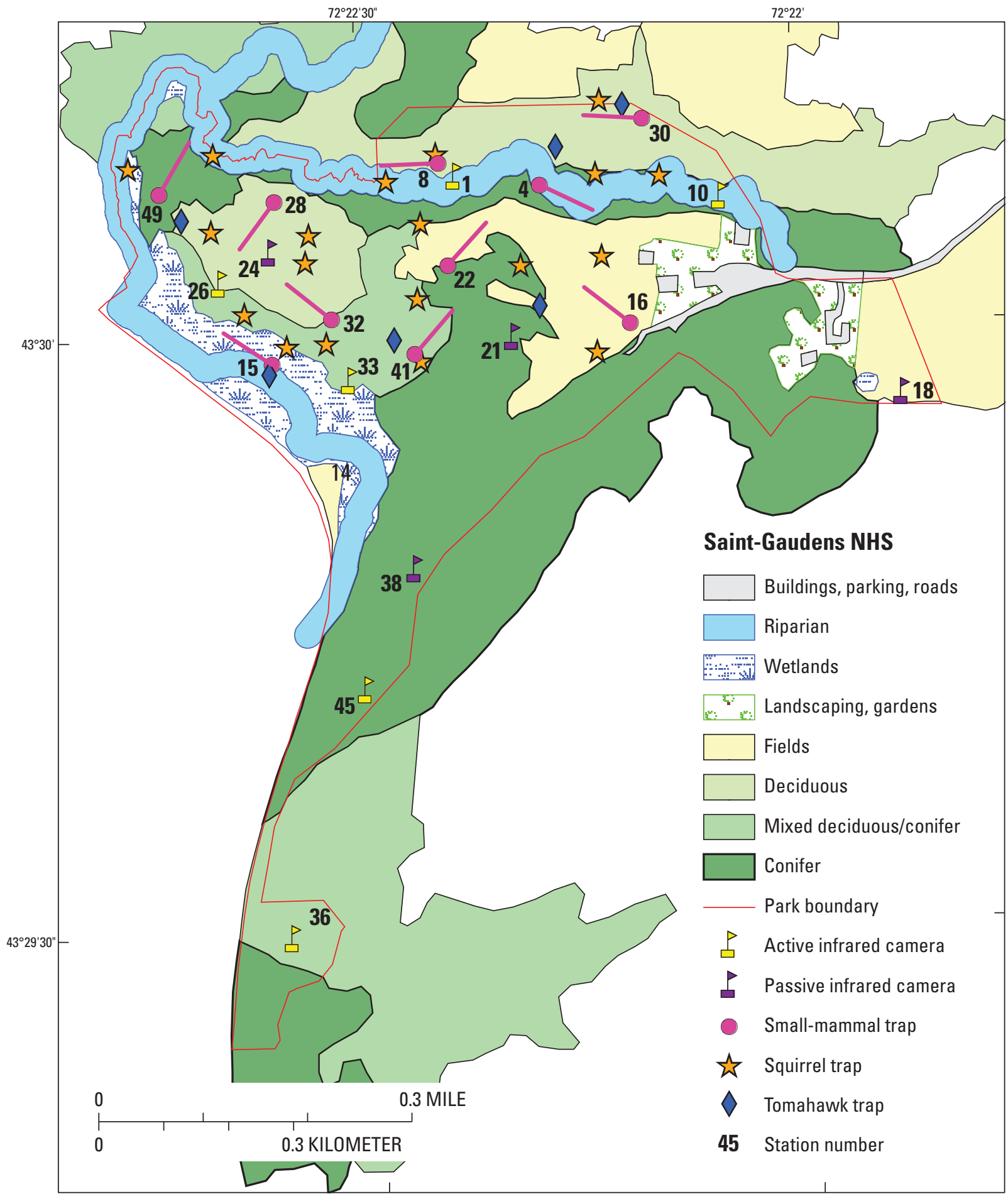

Prepared by: Andrew Gilbert, Patuxent Wildlife Research Center, U.S. Geological Survey, October 2007

Figure 24. Locations of remote cameras and other detection devices, trapping equipment, and orientation of small-mammal trap lines used in the 2004 mammal inventory at Saint-Gaudens National Historic Site. (Two trackplates and two hair traps were arranged about 50 meters from each camera location. Two small-mammal trap lines (10 Longworth and 10 Museum special traps spaced 10 meters between traps) were set parallel to each other 10 meters apart and oriented as shown (pink lines). Two squirrel-sized live traps and, at some stations, a fox-sized live trap completed each trapping station. Station numbers are provided for sampling arrays.) 
Table 33. Community type associations of mammals detected at Saint-Gaudens National Historic Site by indirect measure sampling, trapping, and observation.

[Community type associations are based on vegetation community descriptions of each sampling location. C, camera; TP, trackplate; TR, trapping; X, species observed for which we have records; -, not detected]

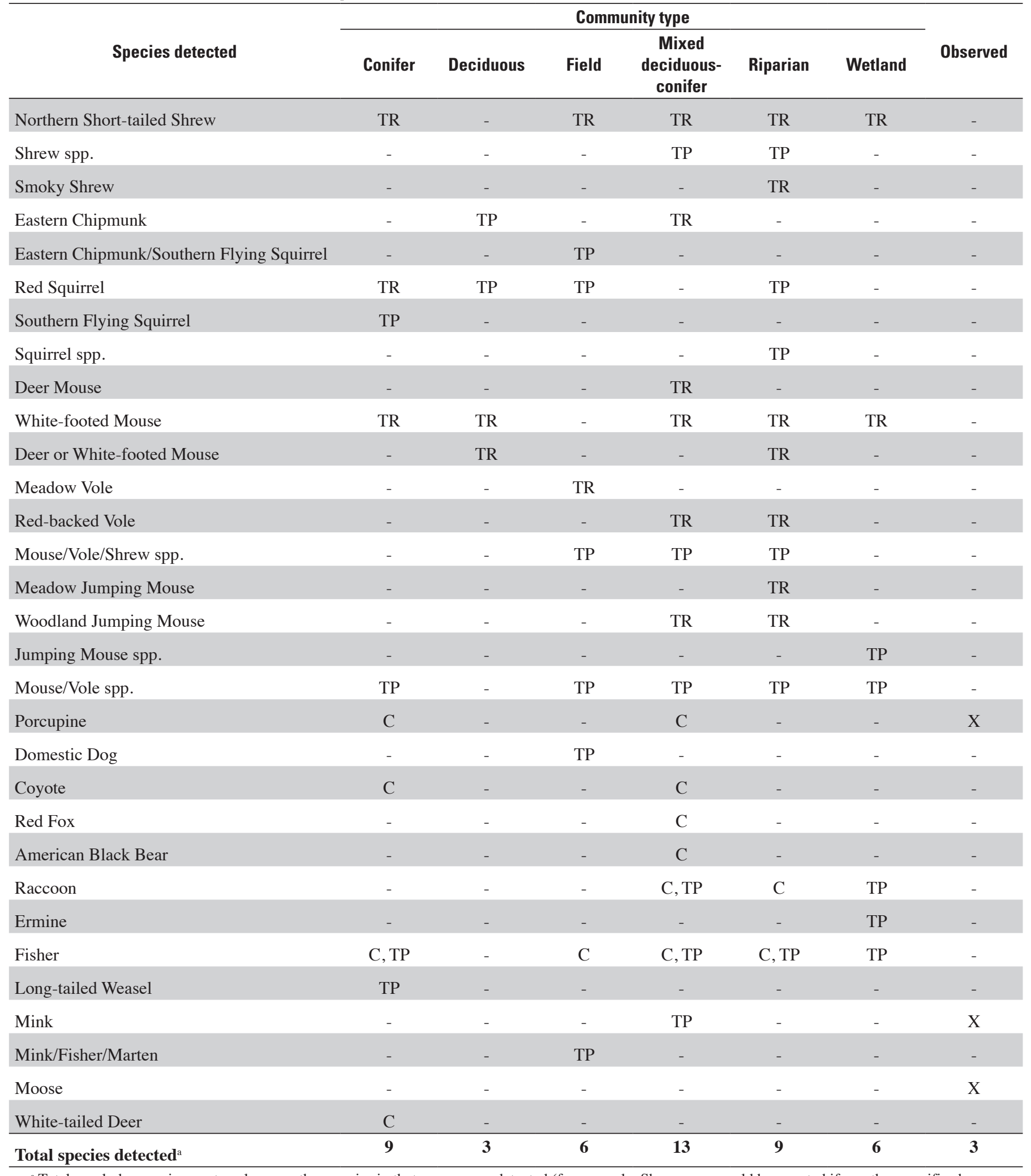

a Totals exclude generic counts unless no other species in that group were detected (for example, Shrew spp. would be counted if no other specific shrew was detected). 
Table 34. Mammal species detection rates and site occupancy at 11 indirect measure stations at Saint-Gaudens National Historic Site during two sampling sessions in 2004.

$[-$, species not detected]

\begin{tabular}{|c|c|c|c|c|}
\hline \multirow{2}{*}{ Species detected } & \multicolumn{2}{|c|}{$\begin{array}{c}\text { Session } 1 \\
(3 / 9 / 2004-3 / 25 / 2004)\end{array}$} & \multicolumn{2}{|c|}{$\begin{array}{c}\text { Session } 2 \\
(9 / 27 / 2004-10 / 22 / 2004)\end{array}$} \\
\hline & $\begin{array}{c}\text { Number of stations } \\
\text { occupied (proportion) }\end{array}$ & $\begin{array}{l}\text { Mean detection } \\
\text { rate }(\mathrm{SE})^{\mathrm{a}}\end{array}$ & $\begin{array}{c}\text { Number of stations } \\
\text { occupied (proportion) }\end{array}$ & $\begin{array}{l}\text { Mean detection } \\
\text { rate (SE) }\end{array}$ \\
\hline Shrew spp. & - & - & $4(0.36)$ & $0.16(0.08)$ \\
\hline Eastern Chipmunk & - & - & $1(0.09)$ & $0.05(0.05)$ \\
\hline Red Squirrel & $1(0.09)$ & $0.02(0.02)$ & $3(0.27)$ & $0.07(0.04)$ \\
\hline Southern Flying Squirrel & - & - & $1(0.09)$ & $0.02(0.02)$ \\
\hline Squirrel spp. & - & - & $1(0.09)$ & $0.02(0.02)$ \\
\hline Mouse/Vole spp. & $4(0.36)$ & $0.09(0.04)$ & $9(0.82)$ & $0.43(0.10)$ \\
\hline Mouse/Vole/Shrew spp. & $1(0.09)$ & $0.02(0.02)$ & $4(0.36)$ & $0.09(0.04)$ \\
\hline Coyote & $1(0.09)$ & $0.04(0.04)$ & $1(0.09)$ & $0.02(0.02)$ \\
\hline Domestic Dog & $1(0.09)$ & $0.02(0.02)$ & $1(0.09)$ & $0.02(0.02)$ \\
\hline Red Fox & - & - & $2(0.18)$ & $0.05(0.03)$ \\
\hline Raccoon & $4(0.36)$ & $0.22(0.14)$ & $6(0.55)$ & $0.43(0.16)$ \\
\hline Black Bear & - & - & $1(0.09)$ & $0.02(0.02)$ \\
\hline Mink/Fisher/Marten & $1(0.09)$ & $0.02(0.02)$ & - & - \\
\hline White-tailed Deer & $1(0.09)$ & $0.02(0.02)$ & $2(0.18)$ & $0.09(0.06)$ \\
\hline
\end{tabular}

${ }^{a}$ The mean rate of detection and standard error over all stations, including those stations where the species was not detected $($ detection rate $=0)$. Species detection rates were calculated for each station by dividing the total number of individual species detections for all checks at a station (camera and trackplate only) by the number of checks made at that station. SE, the standard error of this mean. 
such as wet meadows, swamps, and streams to feed (Whitaker and Hamilton, 1998). Moles are not routinely captured in small-mammal traps and we did not expect to detect them in this survey. It is likely that both Hairy-tailed and Starnosed Moles still occur at SAGA because both species were observed by Cook (1985) and are present in the park voucher collections (table 36).

Snowshoe Hares (Lepus americanus) occur in this area (Whitaker and Hamilton, 1998) but were difficult to detect with the methods we employed. In addition, Snowshoe Hare populations are cyclical (Gillis and Krebs, 1999) and at low densities may be harder to detect. Nevertheless, the occurrence of this species is most easily documented in the winter by their relatively large, shallow, and distinctive tracks in the snow.

Gray Squirrels were not captured or observed during this study, but occur at SAGA wherever trees are found. This sciurid was detected by both Cronan and others (1981) and Cook (1985) and specimens were collected in the county in which the park resides (table 36 ).

Table 35. Mammal capture rates and site occupancy for 10 trapping stations (6 with fox-sized live traps) at SaintGaudens National Historic Site during sampling session 2 (9/27/2004-10/22/2004).

\begin{tabular}{|c|c|c|c|}
\hline Species detected & $\begin{array}{c}\text { Number } \\
\text { of new } \\
\text { captures }\end{array}$ & $\begin{array}{c}\text { Number of } \\
\text { stations } \\
\text { occupied } \\
\text { (proportion) }\end{array}$ & $\begin{array}{c}\text { Mean rate } \\
\text { of new } \\
\text { individuals } \\
\text { captured (SE) }\end{array}$ \\
\hline Smoky Shrew & 1 & $1(0.10)$ & $0.02(0.02)$ \\
\hline $\begin{array}{l}\text { Northern Short-tailed } \\
\text { Shrew }\end{array}$ & 9 & $5(0.50)$ & $0.15(0.07)$ \\
\hline Eastern Chipmunk & 8 & $2(0.20)$ & $0.13(0.10)$ \\
\hline Red Squirrel & 1 & $1(0.10)$ & $0.02(0.02)$ \\
\hline Deer Mouse & 2 & $1(0.10)$ & $0.03(0.03)$ \\
\hline White-footed Mouse & 37 & $7(0.70)$ & $0.62(0.17)$ \\
\hline $\begin{array}{l}\text { Deer or White-footed } \\
\text { Mouse }\end{array}$ & 3 & $3(0.30)$ & $0.05(0.03)$ \\
\hline Meadow Vole & 11 & $2(0.20)$ & $0.18(0.14)$ \\
\hline Red-backed Vole & 2 & $2(0.20)$ & $0.03(0.02)$ \\
\hline Meadow Jumping Mouse & 1 & $1(0.10)$ & $0.02(0.02)$ \\
\hline $\begin{array}{l}\text { Woodland Jumping } \\
\text { Mouse }\end{array}$ & 6 & $2(0.20)$ & $0.10(0.08)$ \\
\hline
\end{tabular}

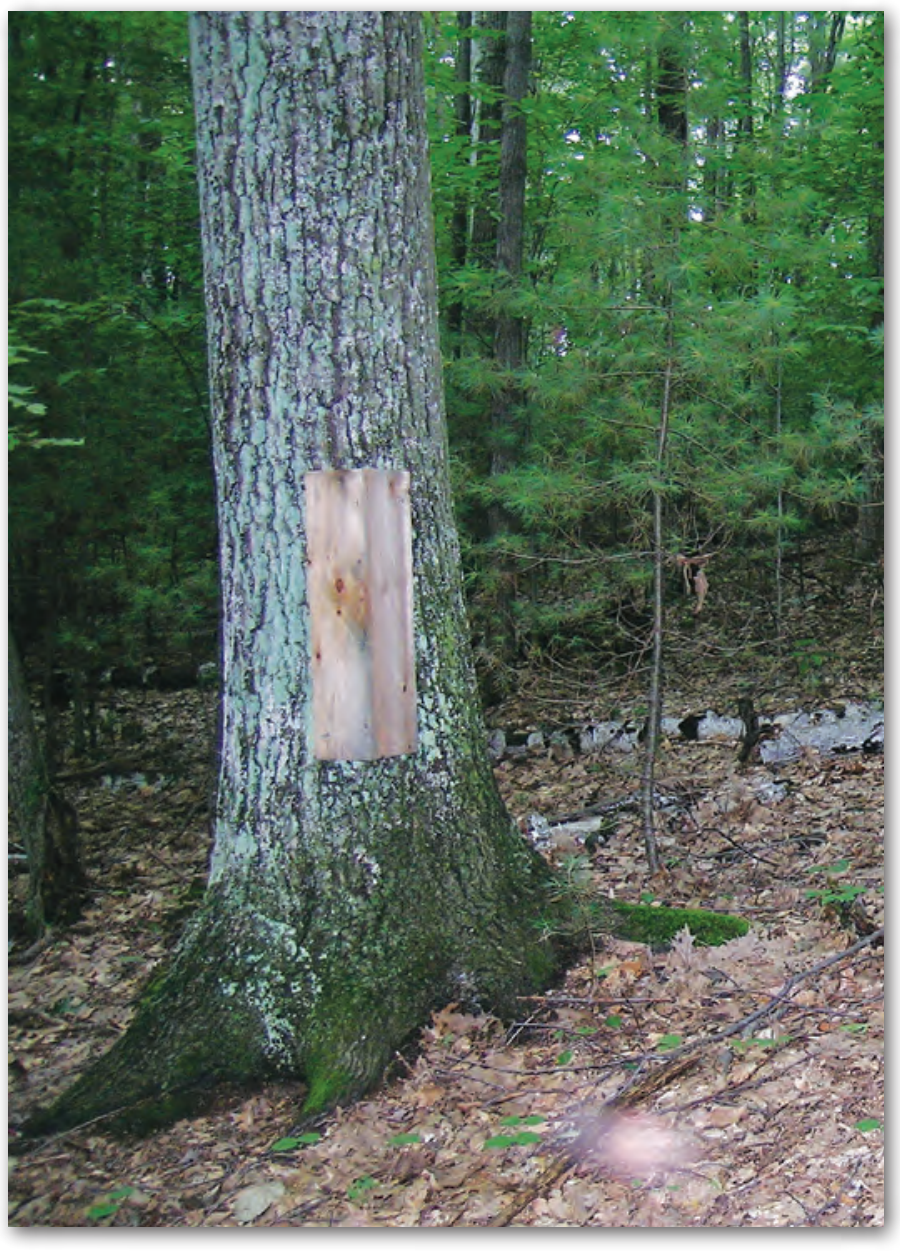

Beaver, Muskrat, and River Otters are common residents of wetlands but were not well sampled by the methods we used in this inventory. Evidence of Beaver and Muskrat in Blow-Me-Down Pond in the recent past includes lodges, cut trees, and mounds as reported by Cronan and others (1981) and Cook (1985). River Otters are more difficult to detect, but were observed in Blow-Me-Down Pond by Cook (1985). The presence of this species is most easily confirmed by observing their tell-tale slides around ponds and streams in the winter.

Gray Fox (Urocyon cinereoargenteus) were not detected at SAGA despite having been encountered at nearby MarshBillings-Rockefeller NHP. However, Coyotes may have displaced this species as a result of interference competition and predation (Fedriani and others, 2000). This species, if present, probably was not abundant locally.

\section{Endangered and Threatened Species}

We did not detect any species that were listed as state or federally threatened, endangered, or of special concern. The State of New Hampshire lists the Small-Footed Myotis (Myotis leibii) and Canada Lynx (Lynx canadensis) as endangered and the Pine Marten (Martes americana) as threatened (New Hampshire Fish and Game Department, 2005). Canada Lynx is also listed as federally threatened. 


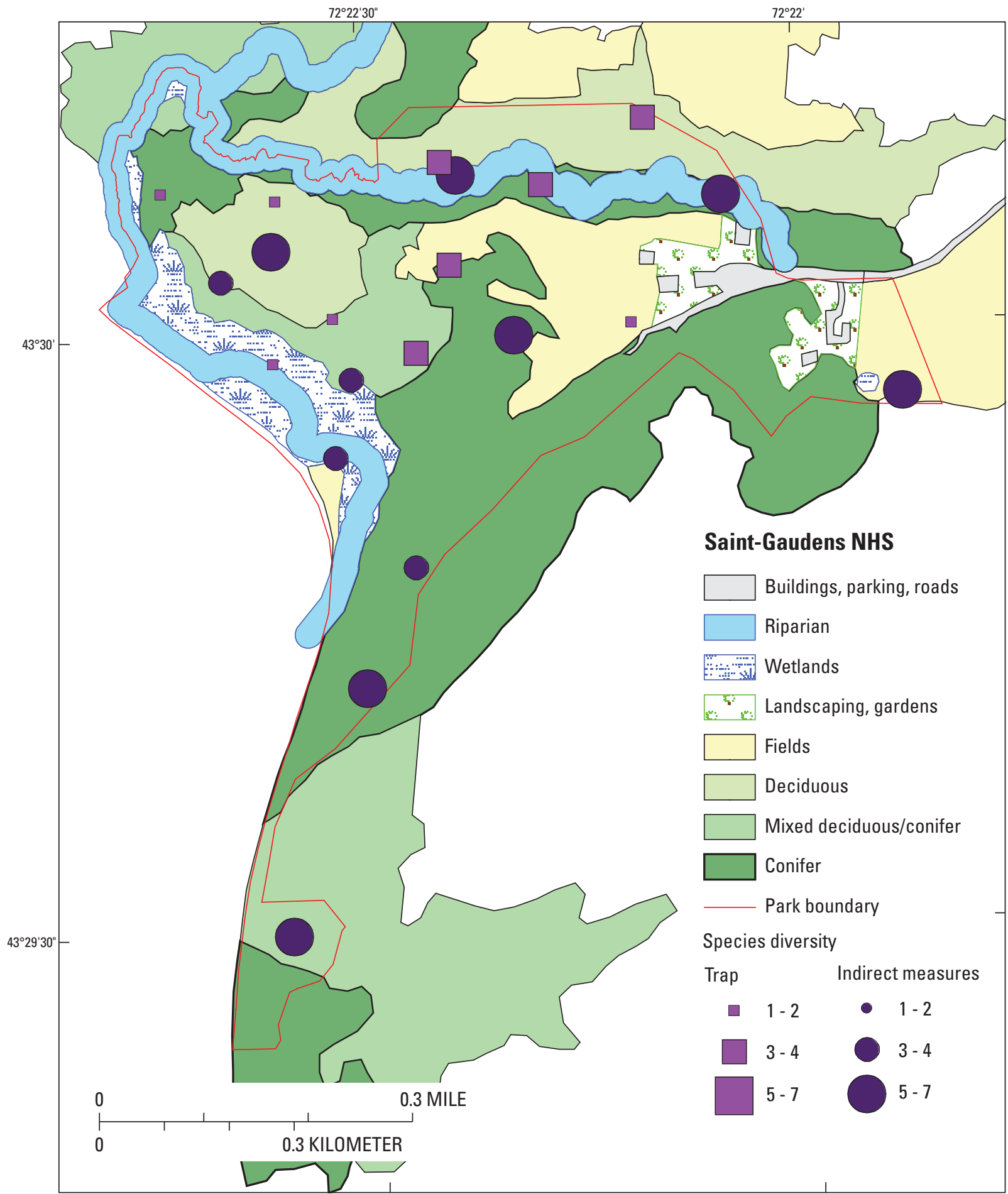

Prepared by: Andrew Gilbert, Patuxent Wildlife Research Center, U.S. Geological Survey, October 2007

Figure 25. Species diversity at trapping and indirect measure sampling stations during the 2004 mammal inventory at Saint-Gaudens National Historic Site. 
Small-footed Myotis is considered one of the rarest bats in North America and is found in mountainous regions throughout the Northeast, including New Hampshire (Best and Jennings, 1997). They hibernate in caves or mines during the winter and will use rock crevices for summer roosting, but little else is known about their ecology (Best and Jennings, 1997; Whitaker and Hamilton, 1998). A single hibernaculum (Mascot Lead Mine) is known for this species in southeastern Coos County (University of New Hampshire Cooperative Extension, 1998; Veilleux and Reynolds, 2005). The Smallfooted Myotis has been documented in the White Mountain National Forest, Bartlett, New Boston, Peirmont, and Surry during the summer (Veilleux and Reynolds, 2005). Given that summer observations are widespread from across the state and that suitable habitat occurs at SAGA, this species may roost here during the warmer months. However, the Smallfooted Myotis has never been documented in the park or surrounding area.

Canada Lynx are associated with the high-elevation boreal forest, preferring deep snow cover where they can pursue their principal prey, the Snowshoe Hare (Hoving and others, 2005). They have been observed recently (1987-95) in northern New Hampshire (Hoving and others, 2003). Recent modeling efforts have shown that Lynx are unlikely to occur in areas with less than $270 \mathrm{~cm} / \mathrm{yr}$ of snow or areas dominated by deciduous forest (Hoving and others, 2005). Total annual snowfall at nearby Lebanon Airport averages $185 \mathrm{~cm}$ (National Climatic Data Center, 2005) and therefore Lynx probably do not inhabit New Hampshire in the vicinity of SAGA.

Pine Marten are found in a variety of habitats in the Northeast, ranging from mid-successional to mature coniferous and deciduous forest types (Kelly, 2005). The original range in colonial times extended into southern Maine, New Hampshire, and Vermont, but this species is now relegated to the northernmost counties of these New England states (Whitaker and Hamilton, 1998). In addition, high-density populations of Fisher can limit Marten (Krohn and others, 1997) and Fisher appear to be common at SAGA, given that they were our most frequently detected species in this park. Thus, for these reasons, future expansion of Marten back into southern New Hampshire around SAGA is unlikely.

Table 36. Number of mammal specimens in museum collections and their proximity to Saint-Gaudens National Historic Site.

[Proximity-to-park codes: 1, collected within park boundaries; 2, collected in the town (Cornish, N.H.) the park is located in; 3, collected in the county (Sullivan) the park is located in. Institutions: AMNH, American Museum of Natural History; CM, Carnegie Museum of Natural History; CUMV, Cornell University Museum of Vertebrates; FMNH, Field Museum of Natural History; KUNHM, University of Kansas, Natural History Museum; SAGA, Saint-Gaudens National Historic Site; UMMZ, University of Michigan Museum of Zoology. -, no specimens]

\begin{tabular}{|c|c|c|c|c|}
\hline \multirow[b]{2}{*}{ Species $^{\mathrm{a}}$} & \multicolumn{3}{|c|}{ Proximity to park } & \multirow[b]{2}{*}{ Institution } \\
\hline & 1 & 2 & 3 & \\
\hline Smoky Shrew (Sorex fumeus) & 2 & - & - & SAGA \\
\hline Northern Short-tailed Shrew (Blarina brevicauda) & 2 & - & 2 & SAGA, UMMZ \\
\hline Star-nosed Mole (Condylura cristata) & 1 & - & - & SAGA \\
\hline Indiana Bat (Myotis sodalis) & - & - & 1 & CUMV \\
\hline Little Brown Bat (M. lucifugus) & - & - & 4 & CUMV, UMMZ \\
\hline Big Brown Bat (Eptesicus fuscus) & 1 & - & - & SAGA \\
\hline Eastern Chipmunk (Tamias striatus) & 1 & - & 1 & SAGA, UMMZ \\
\hline Gray Squirrel (Sciurus carolinensis) & - & - & 3 & KUMNH, UMMZ \\
\hline Deer Mouse (P. maniculatus) & 2 & - & - & SAGA \\
\hline Meadow Vole (Microtus pennsylvanicus) & 2 & - & - & SAGA \\
\hline Red-backed Vole (Clethrionomys gapperi) & 2 & - & - & SAGA \\
\hline Woodland Jumping Mouse (Napaeozapus insignis) & 2 & - & - & SAGA \\
\hline Meadow Jumping Mouse (Zapus hudsonius) & 1 & - & - & SAGA \\
\hline Fisher (Martes pennanti) & - & - & 2 & CM, KUMNH \\
\hline Bobcat (Lynx rufus) & - & - & 1 & $\mathrm{CM}$ \\
\hline
\end{tabular}

${ }^{a}$ Specimen data available through the National Park Service, NPSpecies database. For more information see: Gilbert and O'Connell, 2004; O'Connell and others, 2004; and A.F. O'Connell and A.T. Gilbert, unpublished data available at the USGS Patuxent Wildlife Research Center laboratory in Beltsville, Md. 


\section{Marsh-Billings-Rockefeller National Historical Park (MABI)}

\section{Background}

Marsh-Billings-Rockefeller National Historical Park (MABI) is unique among the national parks in its focus on conservation history and land stewardship (Mitchell and others, 2006). This park lies within the rural village of Woodstock in the mountains of eastern Vermont. The Billings Farm \& Museum, Billings Park, and Vermont Land Trust properties border MABI and in total comprise a large area of conservation land. The 260-ha park is heavily forested, consisting of naturally regenerated northern hardwoods, mixed conifers, and a large amount of plantation forest (Mitchell and others, 2006). A small pond, the Pogue, is located in the interior of the park. A stream draining the Pogue is the only flowing water within the park, although the nearby Ottauquechee River flows to the east and Barnard Brook flows to the north. There are few wetlands in the park except for hillside seeps, small forested wetlands, and wetlands associated with the Pogue and its outlet. A system of carriage roads traverses the park, allowing visitors to access most areas.

\section{Prior Investigations}

A survey of bats was conducted at MABI during 5 days of sampling in late summer 2001 (Reynolds and McFarland,
2001). The Little Brown Bat (Myotis lucifugus) and Longeared Bat (M. septentrionalis) were captured and the Big Brown Bat (Eptesicus fuscus), Eastern Pipistrelle (Pipistrellus subflavus), Hoary Bat (Lasiurus cinereus), Red Bat (L. borealis), and Silver-haired Bat (Lasionycteris noctivagans) were detected by acoustic monitoring. Additional Myotis species were also detected in large numbers by acoustic monitoring, but it was not possible to identify individual species at that time.

Small mammals were captured during an inventory of amphibians and reptiles at MABI in 1999-2000 (Faccio, 2001). Pitfall traps with 30-m drift fences were used for this inventory and set at four locations in forested wetlands just east of the Pogue. Eight species were captured and are listed in order of decreasing capture frequency: Masked Shrew (Sorex cinereus), Northern Short-tailed Shrew (Blarina brevicauda), Meadow Vole (Microtus pinetorum), Deer or White-footed Mouse (Peromyscus spp.), Smokey Shrew (Sorex fumeus), Woodland Jumping Mouse (Napaeozapus insignis), Star-nosed Mole (Condylura cristata), and Hairy-tailed Mole (Parascalops breweri).

\section{Sampling Stations}

Indirect measure sampling was conducted in March and trapping was conducted in September 2004. We selected 26 sampling points (14 IM and 12 trap) in seven community types prior to beginning field work (table 37, fig. 26). We limited trapping to 12 stations (of 14 maximum) to guarantee that we could check all traps every day.

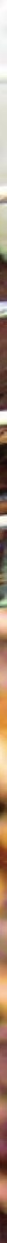


Table 37. Indirect measure (IM) and trap station numbers, community type, GPS locations of the camera at IM stations and beginning of the Longworth trap lines, orientation of IM stations, and bearing of trap lines at Marsh-Billings-Rockefeller National Historical Park.

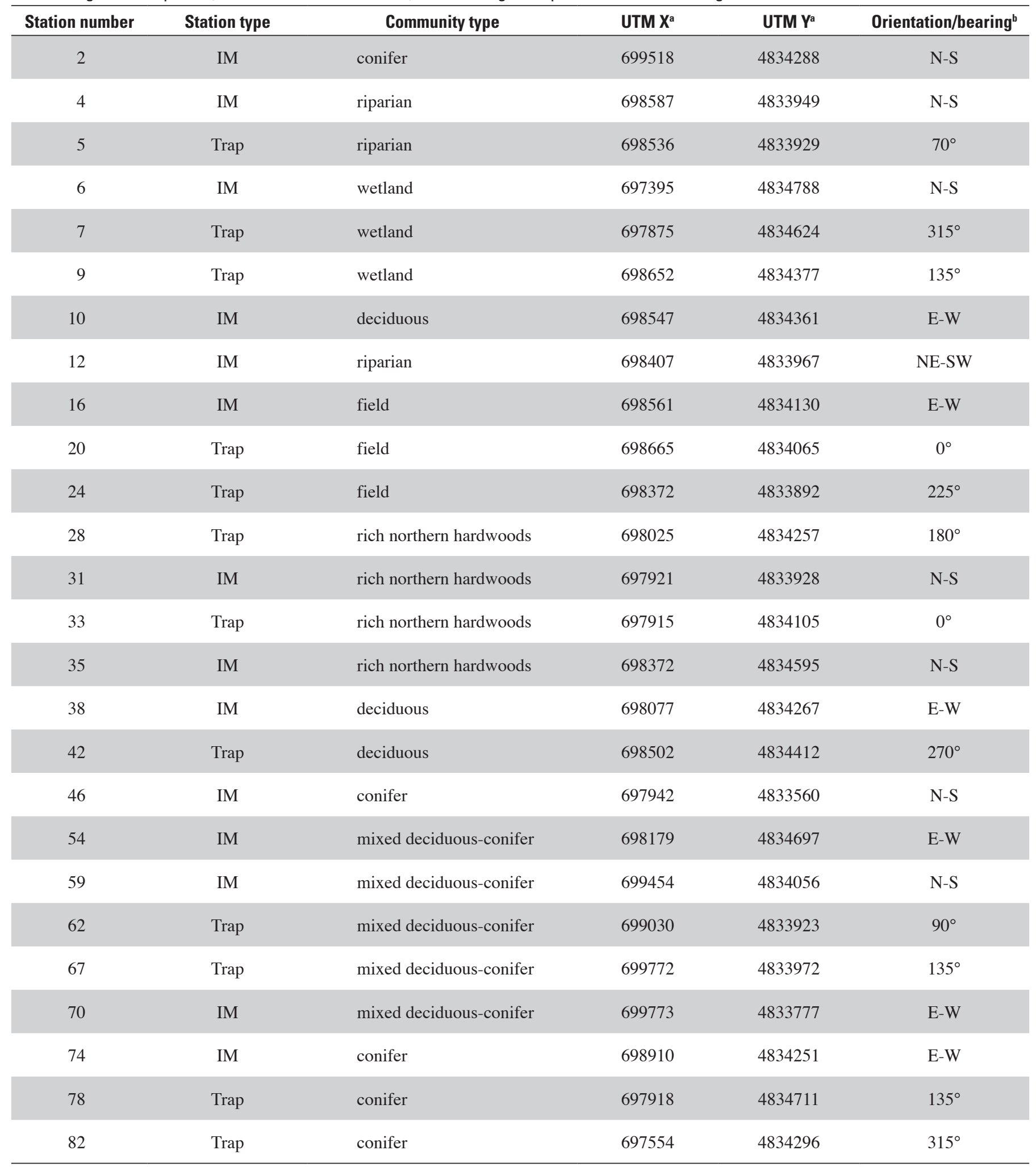

${ }^{a}$ Universal Transverse Mercator Zone 18; datum, North American Datum 1983; units, meters.

${ }^{\mathrm{b}}$ The orientation of the trackplates relative to the cameras in the IM station or the bearing of the trap lines. 

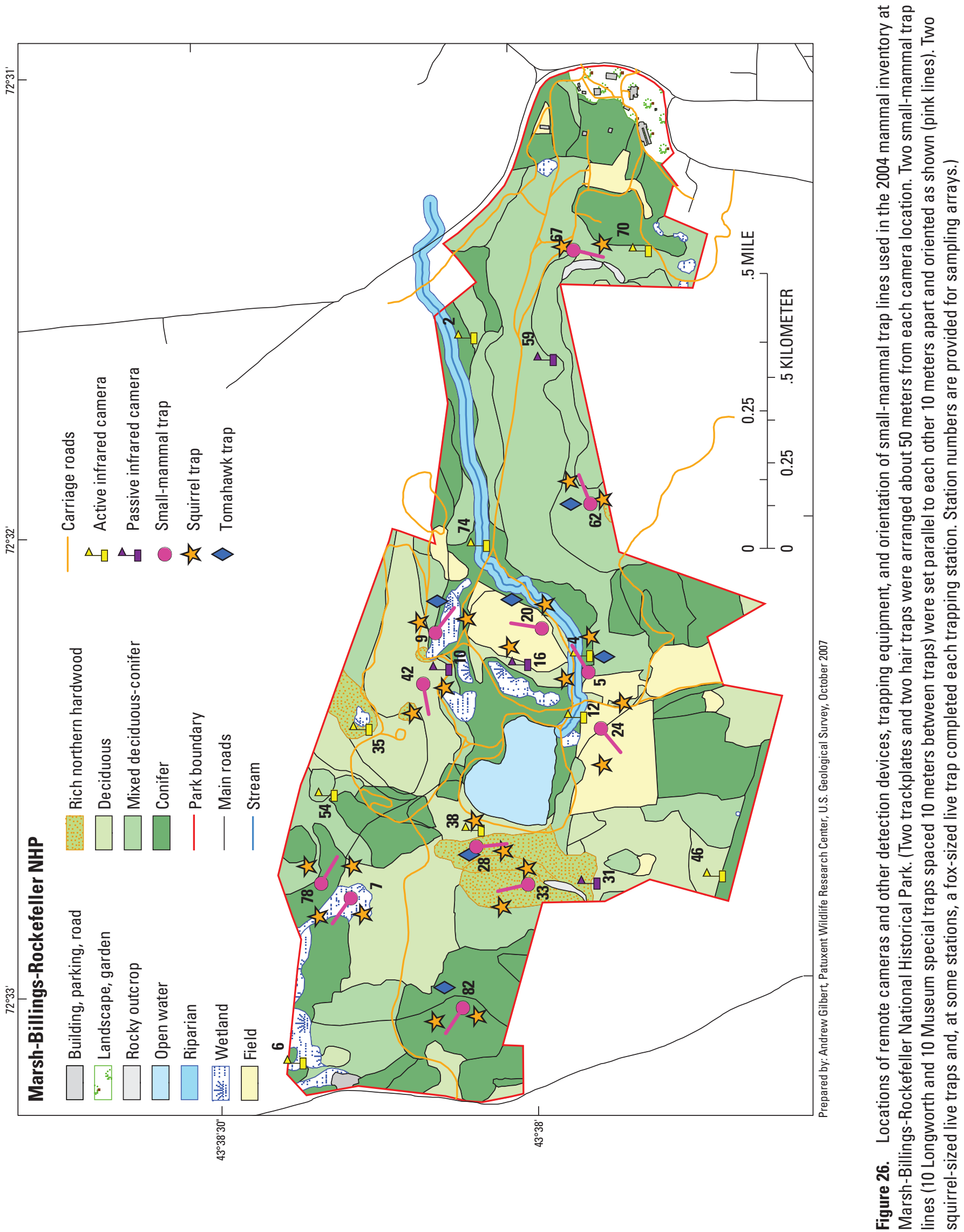


\section{Survey Results}

Twenty-three species were detected at MABI: 16 during IM sampling, 12 by trapping, and 3 by observation (table 38). This is 47 percent of the potential number of mammal species that could occur in the park $(\mathrm{N}=49$, table 1$)$, excluding bats. Fisher (Martes pennanti) was the most commonly detected species during both sampling sessions (table 39). Fishers occurred throughout the park and were detected in all but field and wetland community types (table 38). Raccoon (Procyon lotor) was the next most frequently detected species, occurring in all but field and wetland community types. Additionally, we detected canids (Coyote (Canis latrans), Red Fox (Vulpes vulpes), and Gray Fox (Urocyon cinereoargenteus)) infrequently and small mustelids (Mink (Mustela vison), Long-tailed Weasel ( $M$.frenata), and Ermine (M. erminea)) infrequently (table 39).

The Deer Mouse (Peromyscus maniculatus) was the most commonly captured small-mammal species $(\mathrm{N}=72)$ at MABI, followed by the Northern Short-tailed Shrew (N=32) and Meadow Vole $(\mathrm{N}=20)$ (table 40). Deer Mouse was found in all but the field community type, where the Meadow Vole was the species most frequently captured. Only one Masked Shrew was captured during this study, but it was the small mammal most frequently captured in pitfall traps by Faccio (2001). Smokey Shrew, Woodland Jumping Mouse, and Starnosed Mole were also captured by Faccio (2001), but were not detected in this study.

Species diversity varied among vegetation community types, with 3 to 15 species detected (table 38), and no geographic area of the park appeared to have greater species diversity than any other (fig. 27). More species ( $\mathrm{N}=15)$ were detected in the mixed forest type than in other communities. Conifer and northern hardwoods communities had the next highest number of species detected ( $\mathrm{N}=9$ ), but this comparison does not account for differences in sampling effort between community types.

\section{Species Expected but Not Detected}

Smokey Shrews were detected by Faccio (2001), but not in this study. Shrews were not well documented in this inventory because we did not use pitfall traps. (For a detailed explanation of this issue please refer to the Trapping section on p. 13.) It is clear from Faccio's (2001) work that several shrews occur in MABI and are fairly common. Because Smokey Shrews were captured recently, it is likely that this species still occurs in the park.

We found a single Hairy-tailed Mole at MABI, beside the carriage road near the west gate. Moles are primarily fossorial, preferring to tunnel underground for food, although the Starnosed Mole also makes use of wet areas such as wet meadows, swamps, and streams to feed (Whitaker and Hamilton, 1998). Moles are not routinely captured in small-mammal live traps like the ones we used and so we did not expect to routinely capture these species. Because both mole species were recently captured by Faccio (2001) and moles have been active in the south lawn of the main house (Kyle Jones, National Park Service, oral commun., 2003), we believe these animals still occur throughout the park.

Snowshoe Hare (Lepus americanus) are known to be common in this area (Whitaker and Hamilton, 1998), but we did not detect them and attribute that to the methods we used. Also, Snowshoe Hare populations, like those of other lagomorphs, are highly cyclical, resulting in periodic low densities (Gillis and Krebs, 1999) when they may be more difficult to detect. Their occurrence is most easily confirmed in the winter by their relatively large, shallow, and distinctive tracks in the snow.

Beaver (Castor canadensis), Muskrat (Ondatra zibethicus), and River Otter (Lontra canadensis) are commonly associated with wetlands but we did not detect or capture these species, although our methods were not designed to detect these species. We also did not observe any evidence of these species in the park. The Pogue is the only significant aquatic habitat in the park for these species and is probably too small to support River Otter. However, Barnard Brook and the Ottauquechee River may provide adequate habitat for both Beaver and River Otter. It is possible that individuals of these species can disperse from either waterway and be encountered at the Pogue. Muskrat specimens were collected in Woodstock County (table 41); however, it is unlikely that this species occurs in the park because significant emergent vegetation, a critical food source and shelter material (Godin, 1977), is lacking.

Woodchuck (Marmota monax) burrows were found in the Elm lot and their existence here was confirmed by observations prior to the start of field work. This species is generally common in this region and is probably common within the park.

\section{Endangered and Threatened Species}

We did not detect any species that were listed as state or federally threatened or endangered. The State of Vermont lists the Indiana Bat (Myotis sodalis), Canada Lynx (Lynx Canadensis), and Pine Marten (Martes americana) as endangered and Small-Footed Myotis (Myotis leibii) as threatened (Vermont Fish and Wildlife Department, 2005). The Indiana Bat is also on the Federal endangered species list and Canada Lynx is listed as threatened (50 CFR 17.11).

Indiana Bats (Myotis sodalis) have been documented hibernating in four hibernacula in Vermont since at least 1934 (Trombulak and others, 2001). All four documented hibernacula are within $80 \mathrm{~km}$ of MABI: Plymouth Caves near Plymouth Union is less than $25 \mathrm{~km}$ from MABI, Ely Copper Mine in Vershire and Nickwacket Cave in Chittenden are less than $40 \mathrm{~km}$, and Dorset Caves in Dorset is less than $65 \mathrm{~km}$ from MABI. Recent studies of Indiana Bat spring roost sites in the Lake Champlain Valley have shown that some Indiana Bats may use roosts in nearby areas (up to $40 \mathrm{~km}$ distant) following departure from their winter hibernaculum (Britzke and others, 
Table 38. Community type associations of mammals detected at Marsh-Billings-Rockefeller National Historical Park by indirect measure sampling, trapping, and observation.

[Community type associations are based on vegetation community descriptions of each sampling location. C, camera; TP, trackplate; TR, trapping; X, species observed for which we have records; -, not detected]

\begin{tabular}{|c|c|c|c|c|c|c|c|c|}
\hline \multirow[b]{2}{*}{ Species detected } & \multicolumn{7}{|c|}{ Community type } & \multirow[b]{2}{*}{ Observed } \\
\hline & Conifer & Deciduous & Field & $\begin{array}{l}\text { Mixed } \\
\text { decid- } \\
\text { uous- } \\
\text { conifer }\end{array}$ & $\begin{array}{c}\text { Rich } \\
\text { northern } \\
\text { hard- } \\
\text { woods }\end{array}$ & Riparian & Wetland & \\
\hline Hairy-tailed Mole & - & - & - & - & - & - & - & $X$ \\
\hline Masked Shrew & - & - & - & - & - & - & TR & - \\
\hline Shrew spp. & $\mathrm{TP}$ & $\mathrm{TP}$ & - & $\mathrm{TP}$ & $\mathrm{TP}$ & - & TP & - \\
\hline Eastern Chipmunk & TR & - & - & - & - & - & - & - \\
\hline Gray Squirrel & - & - & - & $\mathrm{TP}, \mathrm{TR}$ & - & - & - & - \\
\hline Red Squirrel & TP & - & TR & TP & TP & - & $\mathrm{TP}$ & - \\
\hline Deer Mouse & TR & TR & - & TR & TR & TR & TR & - \\
\hline Deer or White-footed Mouse & TR & $\mathrm{TR}$ & - & TR & TR & TR & TR & - \\
\hline White-footed Mouse & TR & - & - & TR & - & TR & TR & - \\
\hline Jumping Mouse spp. & - & - & - & $\mathrm{TP}$ & - & - & - & - \\
\hline Meadow Vole & - & - & $\mathrm{TR}$ & - & - & - & $\mathrm{TR}$ & - \\
\hline Red-backed Vole & - & - & - & - & $\mathrm{TR}$ & - & - & - \\
\hline Mouse/Vole spp. & $\mathrm{TP}$ & $\mathrm{TP}$ & $\mathrm{TP}$ & $\mathrm{TP}$ & $\mathrm{TP}$ & $\mathrm{TP}$ & $\mathrm{TP}$ & - \\
\hline Gray Fox & - & - & - & - & - & - & $\mathrm{C}$ & - \\
\hline Red Fox & - & - & $\mathrm{C}$ & $\mathrm{C}$ & - & $\mathrm{C}$ & - & - \\
\hline Raccoon & $\mathrm{C}, \mathrm{TP}$ & $\mathrm{C}, \mathrm{TP}$ & - & $\mathrm{C}, \mathrm{TP}$ & $\mathrm{TR}$ & $\mathrm{C}$ & - & - \\
\hline Ermine & - & - & - & $\mathrm{TP}$ & - & - & - & - \\
\hline Fisher & $\mathrm{C}, \mathrm{TP}$ & $\mathrm{C}, \mathrm{TP}$ & - & $\mathrm{C}, \mathrm{TP}$ & $\mathrm{C}, \mathrm{TP}$ & $\mathrm{C}, \mathrm{TP}$ & - & - \\
\hline Long-tailed Weasel & - & - & - & $\mathrm{TP}, \mathrm{TR}$ & - & - & - & - \\
\hline Mink & - & - & - & - & - & - & - & $\mathrm{X}$ \\
\hline White-tailed Deer & - & - & - & $\mathrm{C}$ & - & $\mathrm{C}$ & - & - \\
\hline Total species detected ${ }^{\mathrm{a}}$ & 9 & 5 & 4 & 15 & 9 & 6 & 7 & 3 \\
\hline
\end{tabular}

a Totals exclude generic counts unless no other species in that group were detected (for example, Shrew spp. would be counted if no other specific shrew was detected). 
Table 39. Mammal species detection rates and site occupancy at 14 indirect measure stations at Marsh-Billings-Rockefeller National Historical Park during two sampling sessions in 2004.

$[-$, species not detected $]$

\begin{tabular}{|c|c|c|c|c|}
\hline \multirow{2}{*}{ Species detected } & \multicolumn{2}{|c|}{$\begin{array}{c}\text { Session } 1 \\
(3 / 11 / 2004-3 / 26 / 2004)\end{array}$} & \multicolumn{2}{|c|}{$\begin{array}{c}\text { Session } 2 \\
(10 / 12 / 2004-10 / 26 / 2004) \\
\end{array}$} \\
\hline & $\begin{array}{c}\text { Number of stations } \\
\text { occupied (proportion) }\end{array}$ & $\begin{array}{l}\text { Mean detection } \\
\text { rate }(\mathrm{SE})^{\mathrm{a}}\end{array}$ & $\begin{array}{c}\text { Number of stations } \\
\text { occupied (proportion) }\end{array}$ & $\begin{array}{c}\text { Mean detection } \\
\text { rate }(\mathrm{SE})^{\mathrm{a}}\end{array}$ \\
\hline Shrew spp. & $2(0.14)$ & $0.02(0.02)$ & $7(0.50)$ & $0.25(0.08)$ \\
\hline Gray Squirrel & - & - & $1(0.07)$ & $0.02(0.02)$ \\
\hline Red Squirrel & $1(0.07)$ & $0.03(0.03)$ & $7(0.50)$ & $0.20(0.07)$ \\
\hline Southern Flying Squirrel & $1(0.07)$ & $0.01(0.01)$ & $2(0.14)$ & $0.10(0.07)$ \\
\hline Squirrel spp. & - & - & $7(0.50)$ & $0.16(0.05)$ \\
\hline Jumping Mouse spp. & - & - & $1(0.07)$ & $0.02(0.02)$ \\
\hline Mouse/Vole spp. & $1(0.07)$ & $0.02(0.02)$ & $12(0.86)$ & $0.70(0.13)$ \\
\hline Mouse/Vole/Shrew spp. & $1(0.07)$ & $0.01(0.01)$ & $5(0.36)$ & $0.14(0.06)$ \\
\hline Gray Fox & - & - & $1(0.07)$ & $0.02(0.02)$ \\
\hline Red Fox & - & - & $3(0.21)$ & $0.08(0.04)$ \\
\hline Raccoon & $2(0.14)$ & $0.03(0.02)$ & $7(0.50)$ & $0.21(0.07)$ \\
\hline Ermine & - & - & $1(0.07)$ & $0.05(0.05)$ \\
\hline Fisher & $6(0.43)$ & $0.10(0.04)$ & $11(0.79)$ & $0.88(0.21)$ \\
\hline Long-tailed Weasel & - & - & $1(0.07)$ & $0.02(0.02)$ \\
\hline White-tailed Deer & $2(0.14)$ & $0.02(0.02)$ & $1(0.07)$ & $0.02(0.02)$ \\
\hline
\end{tabular}

${ }^{a}$ The mean rate of detection and standard error over all stations, including those stations where the species was not detected (detection rate $\left.=0\right)$. Species detection rates were calculated for each station by dividing the total number of individual species detections for all checks at a station (camera and trackplate only) by the number of checks made at that station. SE, the standard error of this mean.

Table 40. Mammal capture rates and site occupancy for 12 trapping stations ( 6 with fox-sized live traps) at Marsh-BillingsRockefeller National Historical Park during sampling session 2 (10/12/2004-10/26/2004).

\begin{tabular}{|c|c|c|c|}
\hline Species Detected & $\begin{array}{c}\text { Number of new } \\
\text { captures }\end{array}$ & $\begin{array}{c}\text { Number of stations occupied } \\
\text { (proportion) }\end{array}$ & $\begin{array}{l}\text { Mean rate of new individuals captured } \\
(\mathrm{SE})^{\mathrm{b}}\end{array}$ \\
\hline Masked Shrew & 1 & $1(0.08)$ & $0.01(0.01)$ \\
\hline Northern Short-tailed Shrew & 32 & $9(0.75)$ & $0.44(0.10)$ \\
\hline Eastern Chipmunk & 1 & $1(0.08)$ & $0.01(0.01)$ \\
\hline Gray Squirrel & 1 & $1(0.08)$ & $0.01(0.01)$ \\
\hline Red Squirrel & 1 & $1(0.08)$ & $0.01(0.01)$ \\
\hline White-footed Mouse & 8 & $4(0.33)$ & $0.11(0.05)$ \\
\hline Deer or White-footed Mouse & 13 & $7(0.58)$ & $0.18(0.07)$ \\
\hline Meadow Vole & 20 & $3(0.25)$ & $0.28(0.25)$ \\
\hline Red-backed Vole & 1 & $1(0.08)$ & $0.01(0.01)$ \\
\hline
\end{tabular}




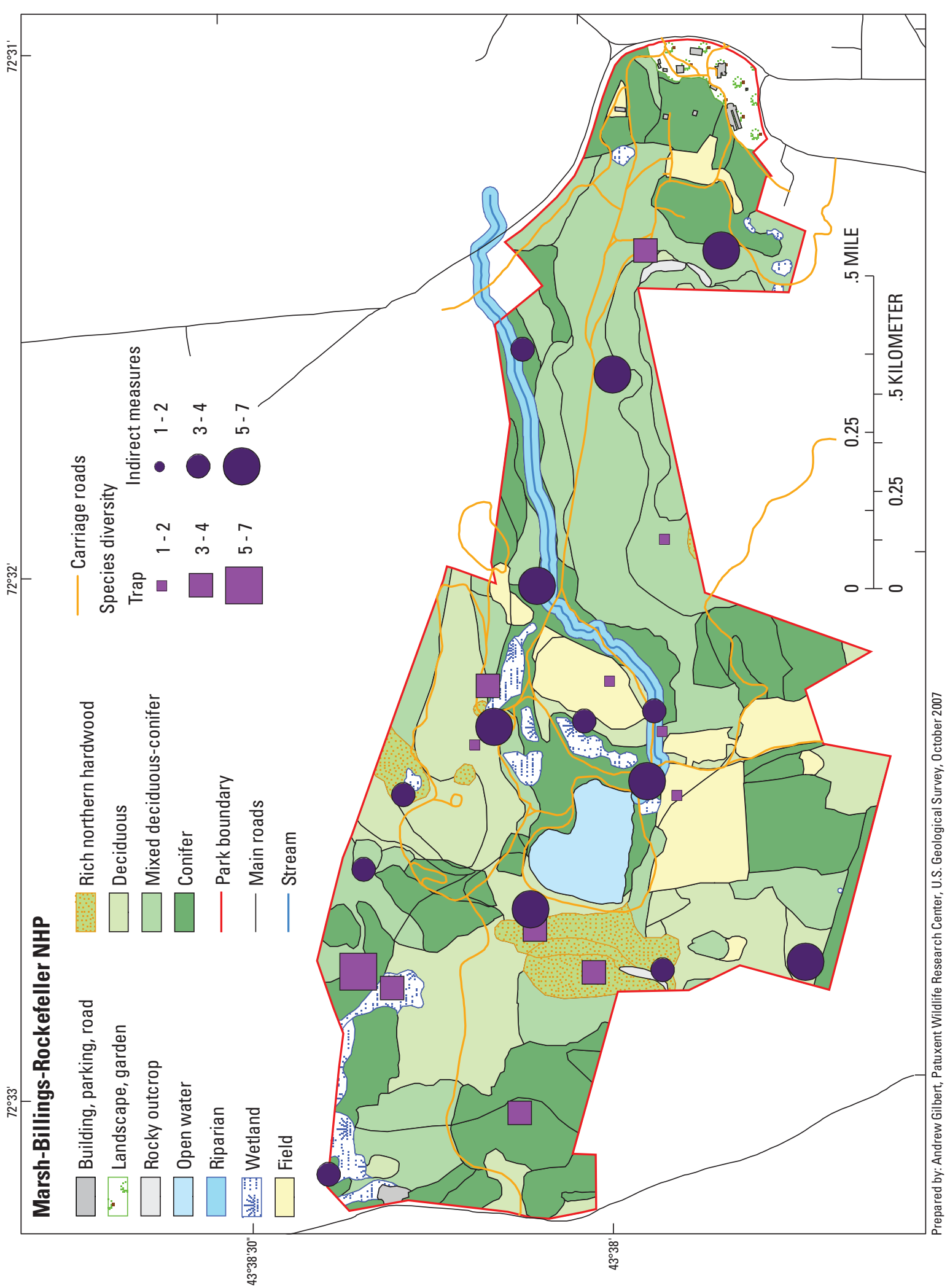


2006). Because three of the four hibernacula are within 40 $\mathrm{km}$ of MABI, the park may serve as a spring or summer roost site. Maternity roosts are found under the loose bark of trees and this species has been known to use elms, oaks, hickories, Cottonwood (Populus deltoides), Silver Maple (Acer saccharinum), and Green Ash (Fraxinus pennsylvanica) (Kurta and others, 1993), especially in riparian areas (Thomson, 1982). Britzke and others (2006) located Indiana Bats roosting in a variety of live and dead trees consisting mostly of live Shagbark Hickory (Carya ovata) and dead American Elm (Ulmus americana), among others. The presence of oaks, ash, and maples at MABI (Lautzenheiser, 2002) might provide appropriate summer roosts for Indiana Bat. A prior inventory of bats at MABI (Reynolds and McFarland, 2001) did not document this bat, but this study was limited in scope. Additional surveys would be necessary to determine whether this species uses the park for roosting.

The Small-footed Myotis is considered one of the rarest bats in North America and is found in mountainous regions throughout the Northeast, including Vermont (Godin, 1977; Best and Jennings, 1997). This species hibernates in caves or mines during the winter and uses rock crevices for summer roosting, but little else is known about the ecology of the species (Best and Jennings, 1997; Whitaker and Hamilton, 1998). Eight hibernacula, including the four known for the Indiana Bat and Quarry Cave, Greely Cave, Brandon Silver Mine, and 1867 Cave, are known to currently or historically have small numbers of hibernating Small-footed Myotis (Trombulak and others, 2001). Small-footed Myotis were not documented by Reynolds and McFarland in their 2001 survey, but this species might be using the park as a summer roosting location. Additional surveys are necessary to determine whether this is true.

Canada Lynx are unlikely to occur in the area around MABI, although historical records indicate a much broader distribution throughout New England prior to 1900 (Hoving and others, 2003). The last documented Lynx in Vermont was recorded in 1968 in Franklin County in northern Vermont, although a specimen was collected in 1965 in the northern part of the county in which MABI is located, Windsor County (McKelvey and others, 1999). If Lynx occur in Vermont, they are likely to be found in high-elevation boreal forest, probably in the northern part of the State. Canada Lynx prefer areas of deep snow through which they can pursue their preferred prey, Snowshoe Hare (Whitaker and Hamilton, 1998; Hoving and others, 2005). Recent modeling efforts have shown that Lynx are unlikely to occur in areas with less than $270 \mathrm{~cm} / \mathrm{yr}$ of snow or areas dominated by deciduous forest (Hoving and others, 2005). Total annual snowfall in Woodstock, Vt., averages 230 cm (National Climatic Data Center, 2006b); therefore, Lynx are not likely to inhabit the MABI region.

We did not detect Pine Marten in this study and believe that viable populations of Marten are unlikely to inhabit this region now or in the future. Pine Marten are found in a variety of habitats in the Northeast, ranging from mid-successional to coniferous and deciduous forest types (Kelly, 2005). Their range in colonial times extended to southern Maine, New Hampshire, and Vermont, but the species has been relegated to the northernmost regions of these New England States (Whitaker and Hamilton, 1998). Marten were reintroduced in the southern Green Mountain National Forest by the Vermont Department of Fish and Wildlife during 1989-91, but that attempt is believed to have failed and no known populations of Marten now occur in this region (Moruzzi and others, 2003). Additionally, competition with Fisher can limit Marten populations (Krohn and others, 1997; Moruzzi and others, 2003; Kart and others, 2005) and, given that Fisher was the most commonly documented species at MABI, they could limit the expansion of Marten back into this region of Vermont. 
Table 41. Number of mammal specimens in museum collections and their proximity to Marsh-Billings-Rockefeller National Historical Park.

[Proximity-to-park codes: 1, collected within park boundaries; 2, collected in the town (Woodstock, Vermont) the park is located in; 3 , collected in the county (Windsor) the park is located in. Institutions: AMNH, American Museum of Natural History, CM, Carnegie Museum of Natural History, CONN, University of Connecticut, EEB, CUMV, Cornell University Museum of Vertebrates, FMNH, Field Museum of Natural History, KUNHM, University of Kansas, Natural History Museum, MCZ, Harvard University, Museum of Comparative Zoology, UMMZ, University of Michigan Museum of Zoology. -, no specimens]

\begin{tabular}{|c|c|c|c|c|}
\hline \multirow[b]{2}{*}{ Species $^{a}$} & \multicolumn{3}{|c|}{ Proximity to park } & \multirow[b]{2}{*}{ Institution } \\
\hline & 1 & 2 & 3 & \\
\hline Smoky Shrew (Sorex fumeus) & - & 2 & 6 & AMNH, MCZ, UMMZ \\
\hline Water Shrew (S.palustris) & - & - & 2 & AMNH \\
\hline Northern Short-tailed Shrew (Blarina brevicauda) & - & 8 & 4 & AMNH, MCZ, UMMZ \\
\hline Hairy-tailed Mole (Parascalops breweri) & - & 1 & 4 & CUMV, MCZ \\
\hline Big Brown Bat (Eptesicus fuscus) & - & 1 & - & $\mathrm{MCZ}$ \\
\hline Hoary Bat (Lasiurus cinereus) & - & 1 & - & $\mathrm{MCZ}$ \\
\hline Gray Squirrel (Sciurus carolinensis) & - & 1 & 2 & $\mathrm{AMNH}, \mathrm{MCZ}$ \\
\hline Red Squirrel (Tamiasciurus hudsonicus) & - & 2 & 10 & AMNH, MCZ, UMMZ \\
\hline Southern Flying Squirrel (Glaucomys volans) & - & 1 & 3 & AMNH, CUMV, MCZ \\
\hline Muskrat (Ondatra zibethicus) & - & - & 3 & $\mathrm{CM}$ \\
\hline Deer Mouse (Peromyscus maniculatus) & - & - & 3 & KUMNH, UMMZ \\
\hline White-footed Mouse (P. leucopus) & - & 12 & 9 & AMNH, MCZ, KUMNH, UMMZ \\
\hline Norway Rat (Rattus norvegicus) & - & - & 2 & AMNH, UMMZ \\
\hline Long-tailed Weasel (Mustela frenata) & - & 1 & - & CUMV \\
\hline $\operatorname{Mink}(M$. vison $)$ & - & 1 & - & $\mathrm{MCZ}$ \\
\hline Fisher (Martes pennanti) & - & 15 & - & CONN \\
\hline Striped Skunk (Mephitis mephitis) & - & - & 1 & CUMV \\
\hline
\end{tabular}

\footnotetext{
a Specimen data available through the National Park Service, NPSpecies database. For more information see: Gilbert and O'Connell, 2004; O'Connell and
} others, 2004; and A.F. O'Connell and A.T. Gilbert, unpublished data available at the USGS Patuxent Wildlife Research Center laboratory in Beltsville, Md. 


\section{Saratoga National Historical Park (SARA)}

\section{Background}

Saratoga National Historical Park (SARA) is an important American Revolutionary War battle site perched over the Hudson River north of Albany, New York. This is the second largest (1,373 ha) park in the NETN. Approximately twothirds of the park is forested by northern hardwoods/mixed conifer forest, and the remaining area is largely agricultural or successional old field (Mitchell and others, 2006). Many small streams transect the park, carving out deep hollows in some areas. The Hudson River is a prominent feature of the eastern portion of the park and a large area of river floodplain can be found within the park. Many trails and several paved roads cross the park.

\section{Prior Research}

According to unpublished park documents, mammals were captured during trapping in 1986 (unpub. report, Saratoga National Historical Park resource management files, Stillwater, New York, 1986). Little is known about this effort, but the following species were captured: Northern Short-tailed Shrew (Blarina brevicauda), Masked Shrew (Sorex cinereus), Long-tailed (Rock) Shrew (S. dispar), Pygmy Shrew (S. hoyi), Smoky Shrew (S.fumeus), Water Shrew (S. palustris), Starnosed Mole (Condylura cristata), Red-backed Vole (Clethrionomys gapperi), Deer Mouse (Peromyscus maniculatus), Woodland Jumping Mouse (Napaeozapus insignis), Meadow Jumping Mouse (Zapus hudsonius), and Eastern Chipmunk (Tamias striatus).

A study of Lyme disease vectors and hosts in the Hudson Valley was conducted in 1987 and 1988 by the State Uni- versity of New York College of Environmental Science and Forestry, Adirondack Ecological Center (P.F. Steblein and N.E. Mathews, unpub. data available from Saratoga National Historical Park, Stillwater, New York, 1988). Several trap types were used including Museum Special and larger generic "rat" traps, Sherman live traps, and pitfall traps, during May to October 1987 and again during June and July 1988. Fourteen mammal species were captured during this study: Northern Short-tailed Shrew, Masked Shrew, Pygmy Shrew, Smoky Shrew, Star-nosed Mole, Gray Squirrel (Sciurus carolinensis), White-footed Mouse (Peromyscus leucopus), Deer Mouse, Meadow Vole (Microtus pennsylvanicus), Meadow Jumping Mouse, Woodland Jumping Mouse, House Mouse (Mus musculus), Norway Rat (Rattus norvegicus), and Muskrat (Ondatra zibethicus).

Small-mammal trapping was conducted by NPS and New York State Museum-Biological Survey personnel during August 13-17, 1990, at three of the sites sampled by Steblein and Mathews and one additional site (New York State Museum, unpub. data available from Saratoga National Historical Park, Stillwater, New York, 1990). Based on these records, the Northern Short-tailed Shrew, Masked Shrew, Smoky Shrew, White-footed Mouse, Deer Mouse, Meadow Vole, Meadow Jumping Mouse, and Ermine (Mustela erminea) were captured.

A study of Hantavirus antibody in populations of small mammals around the country was conducted in 1994 in national parks across the United States, including SARA (Mills and others, 1998). White-footed Mice were captured and tested for reactivity to Hantavirus. No individuals at SARA tested positive for antibody reactivity.

An evaluation of trackplate design for monitoring Mink (M. vison) populations and other mammals was conducted during 1999-2000 at 10 sites in the Hudson River Valley (Loukmas and others, 2001, 2002), including 5 sites at SARA: 2 on Mill Creek, 2 on the Kroma Kill, and 1 on American Creek. During this study, Striped Skunk (Mephitis mephitis), Ermine, Mink, Fisher (Martes pennanti), Domestic Cat (Felis 
silvestris), Virginia Opossum (Didelphis virginiana), unidentified small rodents, unidentified squirrels (Sciurus carolinensis, Tamiasciurus hudsonicus, and Tamias striatus), Raccoon (Procyon lotor), Fox (unspecified species), Muskrat, and Eastern Cottontail (Sylvilagus floridanus) were detected, although details on the species captured at SARA were not reported.

A natural resource damage assessment (NRDA) of the Hudson River, including the stretch contained within Saratoga NHP, was implemented in 2001-02 by the Hudson River Natural Resource Trustees (National Oceanic and Atmospheric Administration, U.S. Department of the Interior, and New York State Department of Environmental Conservation) (Hudson River Trustee Council, 2002). As part of this work, PCB levels were assessed in Little Brown Bats (Myotis lucifugus) and Big Brown Bats (Eptesicus fuscus) at SARA (K. Jahn, unpub. report, Saratoga National Historical Park resource management files, Stillwater, New York, 2004).

\section{Sampling Stations}

Indirect measure sampling was conducted in March/April and November 2004; trapping was conducted in November only. We selected 28 locations for sampling (16 IM and 12 trap) in eight community types prior to beginning field work (table 42; fig. 28). We reduced the number of trapping stations to 12 (of 16) to ensure that all traps could be checked daily.

\section{Survey Results}

Nineteen mammal species were detected at SARA: 18 during indirect measure sampling, 5 by trapping, and 4 by observation (table 43). This is 35 percent of the potential mammals, excluding bats, that could occur in the park $(\mathrm{N}=55$, table 1). The most frequently detected species were Raccoon in winter and the Southern Flying Squirrel (Glaucomys volans) in summer (small mammals excluded) (table 44). Raccoons were distributed throughout the park in most community types except fields and conifer communities (table 43). Gray Fox (Urocyon cinereoargenteus) was the next most commonly detected species in winter, although it was detected at only two stations and was not detected in summer. Southern Flying Squirrels were frequently detected in summer, being found at seven stations across all community types except deep ravines and fields (table 43). White-tailed Deer (Odocoileus virginianus) were commonly observed at SARA (table 44). Fisher also was frequently detected throughout SARA

The only detection of a Bobcat (Lynx rufus) during this inventory was in a conifer stand at SARA. This species has been previously reported at SARA and was described as "rare" in earlier park wildlife reports. In 1955, Bobcats were "observed occasionally as they pass through area on hunting trips" (National Park Service unpub. report, available from Saratoga National Historical Park, Stillwater, New York, 1956). In 1961, two sightings of Bobcats were recorded in the annual wildlife report (National Park Service unpub. report, available from Saratoga National Historical Park, Stillwater, New York, 1961). The status of this species is largely unknown in the park due to its secretive nature, but it is probably rare by virtue of the large size of its home range relative to the size of the park (1,149 ha). Home ranges of Bobcats in Mississippi were 1,719 ha for males and 863 ha for females (Chamberlain and others, 2003). In Florida, females had home ranges of 920 ha (Thornton and others, 2004); in southern Illinois, males had home ranges of 1,940 ha whereas females had home ranges of 910 ha (Nielson and Woolf, 2001). Given that this felid is territorial (Bailey, 1974), these home range estimates indicate that few individuals could reside in the park and their ranges would likely overlap and extend beyond park boundaries.

Only three species of small mammals and two squirrel species were captured at SARA (table 45). The White-footed Mouse was the most frequently captured small mammal species $(\mathrm{N}=70)$, followed by Northern Short-tailed Shrew $(\mathrm{N}=26)$ (table 45). White-footed Mice were trapped in all but mixed deciduous-conifer communities (traps were not set in this community type). Surprisingly, Meadow Voles were not common in the fields in which we set traps. Populations of this species are cyclical, which occasionally results in low population levels. (Ostfeld and Canham, 1995, and references therein).

Species diversity varied among community types from 4 to 13 species detected (table 43), but no geographic area in the park appeared to be more diverse than any other (fig. 29). More species were detected in the deciduous $(\mathrm{N}=13)$ and riparian $(\mathrm{N}=13)$ community types than in the other types (table 43).

\section{Species Expected but Not Detected}

Sorex spp. shrews were not captured in this inventory, but the Masked Shrew, Pygmy Shrew, and Smoky Shrew were captured during previous small-mammal studies. In both of these studies, pitfall traps were used in addition to Museum Specials and Sherman Live traps. Because we did not use pitfall traps in this study, shrews probably were not well documented. (For a detailed explanation of this issue, please refer to the Trapping section on p. 13.) It is clear from previous studies that shrews are more common than we detected, and more diverse. Masked Shrews $(\mathrm{N}=33)$ were commonly captured in 1987-88 and $1990(\mathrm{~N}=42)$, but only a few Smokey Shrews were captured then $(\mathrm{N}=1)$ and in 1990 $(\mathrm{N}=5)$. Also, two Pygmy Shrews were captured at two different locations during the 1987-88 study. Pygmy shrews, as their name suggests, are very small and cannot be captured with snap traps; however, they are readily captured in pitfall traps (Whitaker and Hamilton, 1998). Little is known about the population status of this species (Whitaker and Hamilton, 1998). All three Sorex species of shrews captured previously probably still occur in the park. Masked Shrews are probably the most common, and Smoky Shrews and Pygmy Shrews could be locally abundant where they are found. 
Table 42. Indirect measure (IM) and trap station numbers, community type, GPS locations of the camera at IM stations and beginning of the Longworth trap lines, orientation of IM stations, and bearing of trap lines at Saratoga National Historical Park.

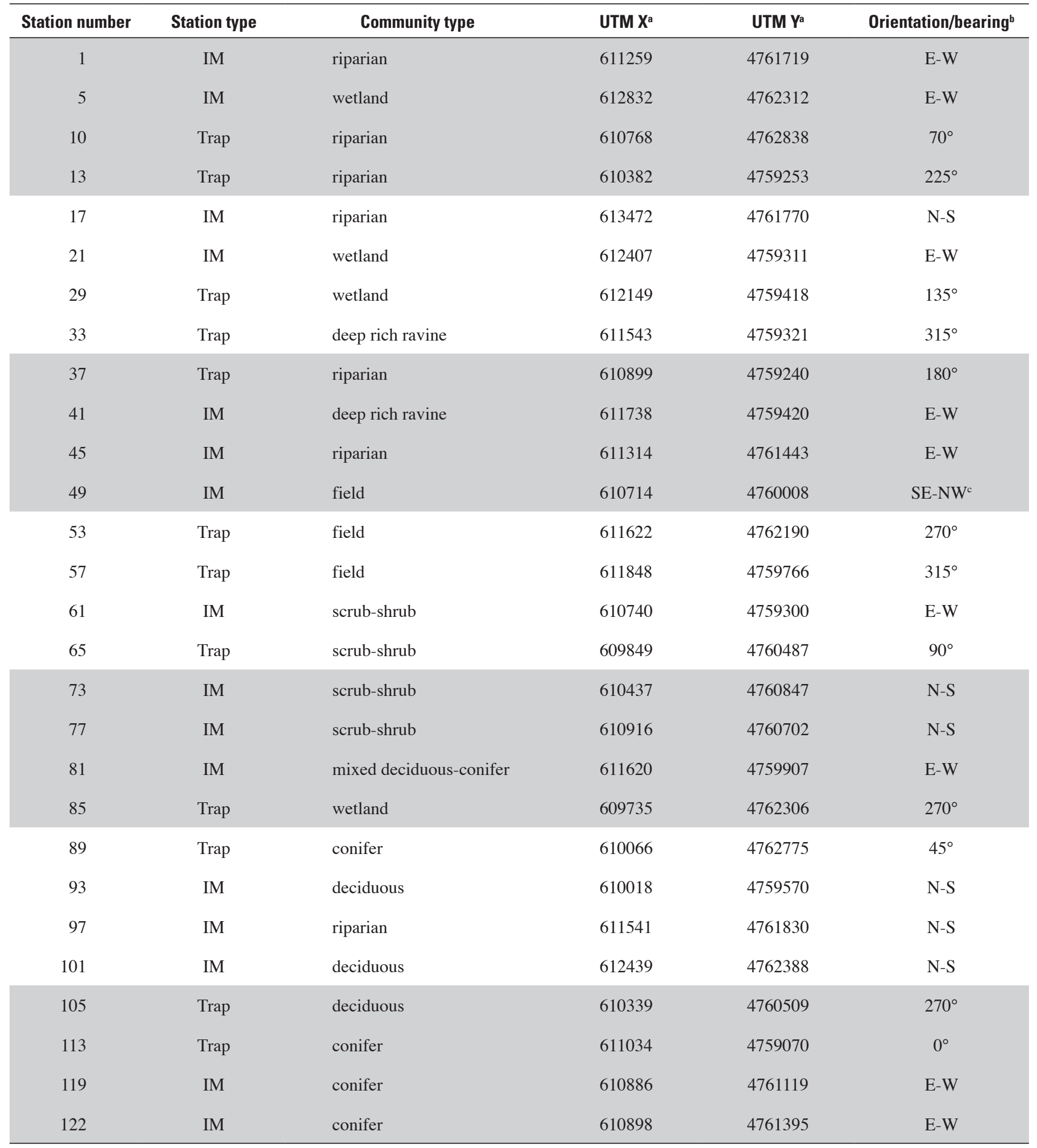

a Universal Transverse Mercator Zone 18; datum, North American Datum 1983; units, meters.

${ }^{\mathrm{b}}$ The orientation of the trackplates relative to the cameras in the IM station or the bearing of the trap lines.

${ }^{c}$ No camera present at this array; coordinates are for the middle of the array. 


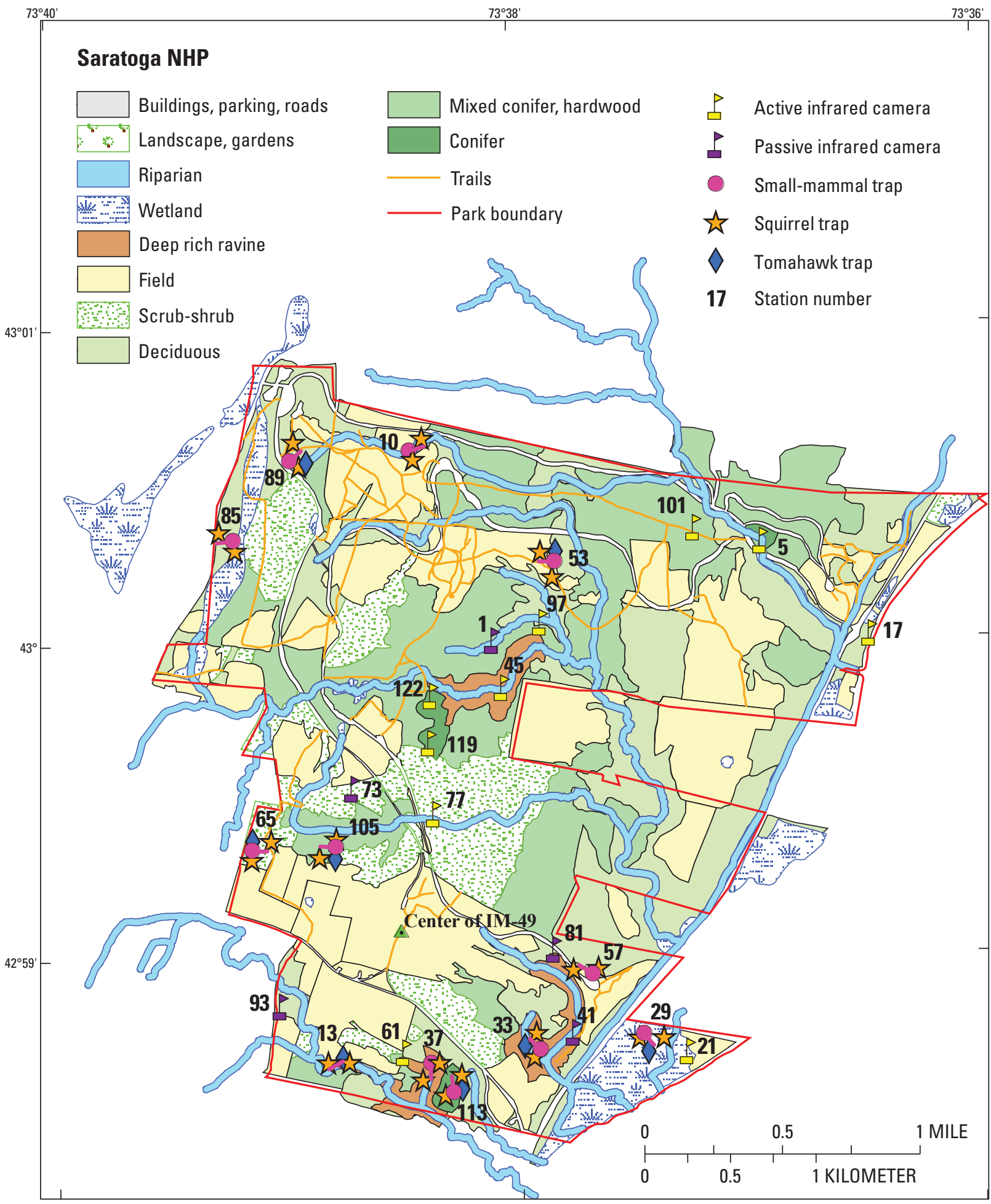

Prepared by: Andrew Gilbert, Patuxent Wildlife Research Center, U.S. Geological Survey, October 2007

Figure 28. Locations of remote cameras and other detection devices, trapping equipment, and orientation of small-mammal trap lines used in the 2004 mammal inventory at Saratoga National Historical Park. (Two trackplates and two hair traps were arranged about 50 meters from each camera location. Two small-mammal trap lines (10 Longworth and 10 Museum special traps spaced 10 meters between traps) were set parallel to each other 10 meters apart and oriented as shown (pink lines). Two squirrel-sized live traps and, at some stations, a fox-sized live trap completed each trapping station. Station numbers are provided for sampling arrays.) 
Table 43. Community type associations of mammals detected at Saratoga National Historical Park by indirect measure sampling, trapping, and observation.

[Community type associations are based on vegetation community descriptions of each sampling location. C, camera; TP, trackplate; TR, trapping; X, species observed for which we have records; -, not detected]

\begin{tabular}{|c|c|c|c|c|c|c|c|c|c|}
\hline Species detected & \multicolumn{8}{|c|}{ Community type } & Observed \\
\hline Northern Short-tailed Shrew & TR & TR & TR & TR & - & TR & TR & TR & $\mathrm{X}$ \\
\hline Shrew spp. & $\mathrm{TP}$ & - & - & $\mathrm{TP}$ & - & - & $\mathrm{TP}$ & $\mathrm{TP}$ & - \\
\hline Eastern or New England Cottontail & - & $\mathrm{C}, \mathrm{TP}$ & - & - & - & $\mathrm{C}$ & $\mathrm{C}, \mathrm{TP}$ & - & $\mathrm{X}$ \\
\hline Eastern Chipmunk & - & - & - & - & - & $\mathrm{TP}$ & - & - & - \\
\hline Gray Squirrel & - & TP, TR & - & - & - & $\mathrm{TP}$ & - & $\mathrm{TP}$ & - \\
\hline Southern Flying Squirrel & $\mathrm{TP}$ & TP, TR & - & - & $\mathrm{TP}$ & $\mathrm{TP}$ & $\mathrm{TP}$ & $\mathrm{TP}$ & - \\
\hline Woodchuck & - & - & - & - & - & $\mathrm{TP}$ & - & - & - \\
\hline White-footed Mouse & TR & TR & TR & TR & - & $\mathrm{TR}$ & $\mathrm{TR}$ & TR & - \\
\hline Deer or White-footed Mouse & - & - & - & - & - & TR & - & TR & - \\
\hline Meadow Vole & TR & TR & - & - & - & TR & - & TR & - \\
\hline Mouse/Vole spp. & $\mathrm{TP}$ & $\mathrm{TP}$ & $\mathrm{TP}$ & $\mathrm{TP}$ & $\mathrm{TP}$ & $\mathrm{TP}$ & TP & $\mathrm{TP}$ & - \\
\hline Mouse/Vole/Shrew spp. & $\mathrm{TP}$ & - & - & $\mathrm{TP}$ & - & $\mathrm{TP}$ & $\mathrm{TP}$ & - & - \\
\hline Fisher & $\mathrm{TP}$ & $\mathrm{TP}$ & - & - & $\mathrm{TP}$ & $\mathrm{TP}$ & $\mathrm{TP}$ & - & - \\
\hline Long-tailed Weasel & - & - & - & - & - & - & $\mathrm{TP}$ & - & - \\
\hline Long-tailed Weasel/Ermine & $\mathrm{C}$ & - & - & - & - & - & $\mathrm{TP}$ & - & - \\
\hline Striped Skunk & - & $\mathrm{TP}$ & - & - & - & $\mathrm{TP}$ & - & - & - \\
\hline Bobcat & $\mathrm{C}$ & - & - & - & - & - & - & - & - \\
\hline Domestic Cat & - & - & - & - & - & $\mathrm{TP}$ & - & - & - \\
\hline White-tailed Deer & $\mathrm{C}$ & $\mathrm{C}$ & - & - & $\mathrm{C}$ & $\mathrm{C}$ & $\mathrm{C}$ & $\mathrm{C}$ & - \\
\hline Total species detected ${ }^{\mathrm{a}}$ & 8 & 13 & 4 & 4 & 5 & 13 & 9 & 9 & 4 \\
\hline
\end{tabular}


Table 44. Mammal species detection rates and site occupancy at 16 indirect measure stations at Saratoga National Historical Park during two sampling sessions in 2004.

$[-$, species not detected $]$

\begin{tabular}{|c|c|c|c|c|}
\hline \multirow{2}{*}{ Species detected } & \multicolumn{2}{|c|}{$\begin{array}{c}\text { Session } 1 \\
(3 / 29 / 2004-4 / 14 / 2004) \\
\end{array}$} & \multicolumn{2}{|c|}{$\begin{array}{c}\text { Session } 2 \\
(11 / 1 / 2004-11 / 22 / 2004)\end{array}$} \\
\hline & $\begin{array}{c}\text { Number of stations } \\
\text { occupied (proportion) }\end{array}$ & $\begin{array}{l}\text { Mean detection } \\
\text { rate }(\mathrm{SE})^{\mathrm{a}}\end{array}$ & $\begin{array}{c}\text { Number of stations } \\
\text { occupied (proportion) }\end{array}$ & $\begin{array}{l}\text { Mean detection } \\
\text { rate }(\mathrm{SE})^{\mathrm{a}}\end{array}$ \\
\hline Shrew spp. & $1(0.06)$ & $0.01(0.01)$ & $3(0.19)$ & $0.06(0.03)$ \\
\hline Eastern or New England Cottontail & $1(0.06)$ & $0.01(0.01)$ & $2(0.12)$ & $0.15(0.11)$ \\
\hline Gray Squirrel & - & - & $4(0.25)$ & $0.11(0.05)$ \\
\hline Rat spp. or Eastern Chipmunk & $1(0.06)$ & $0.01(0.01)$ & $1(0.06)$ & $0.02(0.02)$ \\
\hline Red Squirrel & - & - & $4(0.25)$ & $0.10(0.05)$ \\
\hline Mouse/Vole spp. & $7(0.44)$ & $0.10(0.04)$ & $12(0.75)$ & $0.53(0.13)$ \\
\hline Mouse/Vole/Shrew spp. & $4(0.25)$ & $0.06(0.03)$ & $3(0.19)$ & $0.07(0.04)$ \\
\hline Canid spp. & $1(0.06)$ & $0.02(0.02)$ & - & - \\
\hline Gray Fox & $2(0.12)$ & $0.12(0.10)$ & - & - \\
\hline Raccoon & $5(0.31)$ & $0.16(0.07)$ & $4(0.25)$ & $0.11(0.05)$ \\
\hline Striped Skunk & - & - & $2(0.12)$ & $0.06(0.05)$ \\
\hline Bobcat & $1(0.06)$ & $0.01(0.01)$ & - & - \\
\hline Domestic Cat & - & - & $1(0.06)$ & $0.04(0.04)$ \\
\hline White-tailed Deer & $4(0.25)$ & $0.08(0.04)$ & $7(0.44)$ & $0.22(0.08)$ \\
\hline
\end{tabular}

${ }^{a}$ The mean rate of detection and standard error over all stations, including those stations where the species was not detected (detection rate $\left.=0\right)$. Species detection rates were calculated for each station by dividing the total number of individual species detections for all checks at a station (camera and trackplate only) by the number of checks made at that station. SE, the standard error of the mean. 
Table 45. Mammal capture rates and site occupancy for 12 trapping stations (8 with fox-sized live traps) at Saratoga National Historical Park during sampling session 2 $(11 / 1 / 2004-11 / 22 / 2004)$.

\begin{tabular}{|c|c|c|c|}
\hline Species Detected & $\begin{array}{l}\text { Number } \\
\text { of new } \\
\text { captures }\end{array}$ & $\begin{array}{c}\text { Number of } \\
\text { stations } \\
\text { occupied } \\
\text { (proportion) }\end{array}$ & $\begin{array}{c}\text { Mean rate } \\
\text { of new } \\
\text { individuals } \\
\text { captured (SE) }\end{array}$ \\
\hline $\begin{array}{l}\text { Northern Short-tailed } \\
\text { Shrew }\end{array}$ & 26 & $10(0.63)$ & $0.33(0.11)$ \\
\hline Gray Squirrel & 1 & $1(0.06)$ & $0.01(0.01)$ \\
\hline $\begin{array}{l}\text { Southern Flying } \\
\text { Squirrel }\end{array}$ & 1 & $1(0.06)$ & $0.01(0.01)$ \\
\hline White-footed Mouse & 70 & $11(0.69)$ & $0.88(0.14)$ \\
\hline $\begin{array}{l}\text { Deer or White-footed } \\
\text { Mouse }\end{array}$ & 3 & $3(0.19)$ & $0.04(0.02)$ \\
\hline Meadow Vole & 5 & $4(0.25)$ & $0.06(0.03)$ \\
\hline
\end{tabular}

${ }^{a}$ Rates were calculated for each station by dividing the total number of new individuals captured (per species) by the number of nights that traps were operational. SE, standard error of the mean.

Surveys conducted in 1986 reported the capture of Longtailed and Water Shrews (unpub. report, Saratoga National Historical Park resource management files, Stillwater, New York, 1986). Like the Pygmy Shrew, little is known about the population characteristics of these two shrews and the range of both species includes SARA (Whitaker and Hamilton, 1998). We have no information about this study and cannot comment on the abundance of these species, except that they were not captured in any subsequent surveys. Additional field work would be required to document the occurrence of these species.

We did not capture or observe moles at SARA. Moles are primarily fossorial, preferring to tunnel underground for food, although the Star-nosed Mole also makes use of wet areas such as wet meadows, swamps, and streams to feed (Whitaker and Hamilton, 1998). Moles are not routinely captured in small-mammal live or snap traps and we did not expect to capture them in this inventory. Star-nosed Moles were captured during prior studies (unpub. report, Saratoga National Historical Park resource management files, Stillwater, New York, 1986; P.F. Steblein and N.E. Mathews, unpub. data available from Saratoga National Historical Park, Stillwater, New York, 1988) and likely still occur in the park. No other species of mole was detected in any investigation, but the range of the Hairy-tailed Mole (Parascalops breweri) could include SARA (Whitaker and Hamilton, 1998). Moles occur where they can dig mounded tunnels in softened soil, such as in landscaped areas and forest trails.

Beaver (Castor canadensis), Muskrat, and River Otter (Lontra canadensis) are strongly associated with wetlands but were not well sampled by methods we used in this inventory. Beavers built a lodge and dam in the Old Champlain Canal during the 1960s, which caused problems with road flooding (I.J. Ellsworth, Saratoga National Historical Park resource management files, Stillwater, N.Y., 1963). Evidence of beavers may still be found today along the canal in the Schuylerville unit (Chris Martin, National Park Service, oral commun., 2003), and along the Hudson River. Emergent vegetation wetlands in the park may be too limited to accommodate Muskrat. They were detected during a survey by Loukmas and others (2001), but we do not know whether they were detected in the park or at one of five other stations sampled in the Hudson River Valley that were outside the park. River Otters are semi-aquatic mammals found near streams and rivers; in 1957, a River Otter was found in Palmer, Saratoga County (table 46, unpub. data, Cornell University Museum of Vertebrates, Ithaca, New York). River Otters were not detected by Loukmas and others $(2001,2002)$. This species typically is associated with the deeper streams and rivers, such as the Old Champlain Canal and the Hudson River. The presence of River Otter slides in winter would be a good indication that this species inhabits the park.

Recent reports from visitors and park staff have noted the occurrence of Black Bears in the park (Chris Martin, National Park Service, written commun., 2006), and Moose at the park boundary (Chris Martin, National Park Service, written commun., 2003). Neither species is expected to be a regular inhabitant of the park, but dispersing or ranging individuals could account for these sightings. Moose are less likely to be resident than Black Bears because the southern edge of their current range extends to about Albany in New York (Whitaker and Hamilton, 1998). The distribution of the Black Bear in the East is broader than that of the Moose, extending from Northern New England south through the Appalachians (Whitaker and Hamilton, 1998). Black Bears occur regularly in the Catskill, Allegheny, and Adirondack regions of New York (New York State Department of Environmental Conservation, 2006b). The number of bears harvested in Saratoga County is increasing (New York State Department of Environmental Conservation, 2006g), an indication of increasing population size in this region.

\section{Endangered and Threatened Species}

We did not detect any species that were listed as state or federally threatened or endangered. The State of New York lists the Indiana Bat (Myotis sodalis), Allegheny Woodrat (Neotoma magister), Gray Wolf (Canis lupus), and Eastern Cougar (Felis concolor cougar) as endangered and the Canada Lynx (Lynx canadensis) as threatened. However, of these species, only the Indiana Bat has not been extirpated from New York (New York State Department of Environmental Conservation, 2005f) and is mostly likely to occur in the park. Small-footed Myotis (Myotis leibii) and New England Cottontail (Sylvilagus transitionalis) are listed as species of special concern. 
Indiana Bats are known to occur in eastern New York and have been documented wintering in eight hibernacula in Albany, Essex, Warren, Jefferson, Onondaga, and Ulster Counties (New York State Department of Environmental Conservation, 2005e). Even though this species has not been found wintering in Saratoga County, hibernacula occur to the north in Warren and Essex Counties and to the south in Albany County. It is possible that hibernacula will be found in the future and Indiana Bats may feed or have nursery colonies within the park. Maternity roosts are found under the loose bark of trees and this species has been known to use elms, oaks, hickories, Cottonwood (Populus deltoides), Silver Maple (Acer saccharinum), and Green Ash (Fraxinus pennsylvanica) (Kurta and others, 1993); some of these trees occur in great abundance at SARA. Indiana Bats prefer riparian and floodplain trees (Thomson, 1982), which are also prevalent at SARA. The Hudson River floodplain may be an ideal maternity roosting area given the abundance of suitable roost trees such as Silver Maple and the proximity to prime feeding areas over the Hudson River. A study of bats leaving an Essex County hibernaculum showed that female Indiana Bats roosted extensively in the Champlain Valley of Vermont and New York (Britzke, 2006). Bats leaving hibernacula in nearby counties may also be using the Hudson River Valley as summer nursery sites. We did not survey bats in this study, and do not have any evidence that this species occurs in the park. However, given the proximity to known hibernacula and the presence of appropriate summer roost sites, the presence of this species is possible.

Allegheny Woodrats were once found on cliffs and talus slopes of southeastern New York, but were extirpated from the State by 1987 (New York State Department of Environmental Conservation, 2005a). Their decline may be linked to the increase in Raccoons and their susceptibility to Raccoon Roundworm (Baylisascaris procyonis), a parasite of the Raccoon (New York State Department of Environmental Conservation, 2005a). Climate change has also been suggested as a reason for their decline (Whitaker and Hamilton, 1998), but regardless of the reason, their presence in the State, currently and in the future, is unlikely (New York State Department of Environmental Conservation, 2005a). Some rocky outcrops are present at SARA, especially in deep ravines, but these sites are probably not ideal habitat for this species if and when it returns to New York. Allegheny Woodrat is not expected to occur at SARA.

Cougar and the Gray Wolf were long ago extirpated from New York State (Connor, 1971). Although the State of New York has considered reintroduction of the Gray Wolf as part of the Federal recovery plan for this species in the Adirondack Mountain region (New York State Department of Environmental Conservation, 2005d), there are no plans to reintroduce Cougar to New York (New York State Department of Environmental Conservation, 2005c). Cougar are occasionally observed throughout New York, but they are probably pets that have been released to the wild (New York State Department of Environmental Conservation, 2005c).
These species are unlikely to inhabit SARA unless a reintroduction and subsequent recolonization occurs in the surrounding region.

Canada Lynx are unlikely to reside within the area around SARA, although historical records indicate a much broader distribution throughout the Northeast, including New York, prior to 1900 (Hoving and others, 2003). Lynx were relatively common in the Adirondacks and were recorded east of Albany, but became rare as of the late 1800s. Only 23 records of Lynx are known for the 1900s, most commonly in the Adirondacks (McKelvey and others, 1999). If Lynx occur in New York, they are likely to be found in high-elevation boreal forest, probably in the northern part of the State. Reintroduction of 83 individuals to the Adirondacks was attempted in 1989-91, but the attempt failed (McKelvey and others, 1999). This medium-sized felid lives in areas of deep snow through which it can pursue its preferred prey, the Snowshoe Hare (Whitaker and Hamilton, 1998; Hoving and others, 2005). Recent modeling efforts have shown that Lynx are unlikely to occur in areas with less than $270 \mathrm{~cm} / \mathrm{yr}$ of snow or areas dominated by deciduous forest (Hoving and others, 2005). Total annual snowfall in Albany is $160 \mathrm{~cm}$ (State University of New York at Albany, 2006); therefore, the area around SARA is probably not suitable for Canada Lynx.

Small-footed Myotis is one of the rarest bats in North America and can be found in mountainous regions throughout the Northeast, including New York (Best and Jennings, 1997). They hibernate in caves or mines, but little is known about their summer habits (Whitaker and Hamilton, 1998). Given the lack of information about this species, it is not possible to determine whether this species occurs in SARA.

The New England Cottontail (Sylvilagus transitionalis) is a species of special concern in New York. The Federal government was petitioned to list the species as federally threatened or endangered, and the listing status was recently updated to level two for final determination on the proposed listing (CFR 50-17; 06:53756-53835). The range of the New England Cottontail is believed to be much reduced from its former range (Litvaitis and others, 2003), but the species does occur in the Hudson River Valley (Whitaker and Hamilton, 1998). This lagomorph is closely related to the Eastern Cottontail (S.floridanus), which can also be found in New York, and the two can easily be confused. New England Cottontails prefers dense thickets (Whitaker and Hamilton, 1998; U.S. Fish and Wildlife Service, 2005b), which occur in many areas throughout the park. We detected cottontails in three different community types (table 43), and several road-killed animals were recorded and collected for identification, which is still pending. Species-specific identification as either an Eastern or New England Cottontail requires DNA analysis or examination of skull structure (Whitaker and Hamilton, 1998; U.S. Fish and Wildlife Service, 2005b); therefore, tissue or fecal samples or skeletal material are required (U.S. Fish and Wildlife Service, 2005b). It is possible that the New England Cottontail occurs in SARA, but further analysis of the individuals we collected will be necessary. 


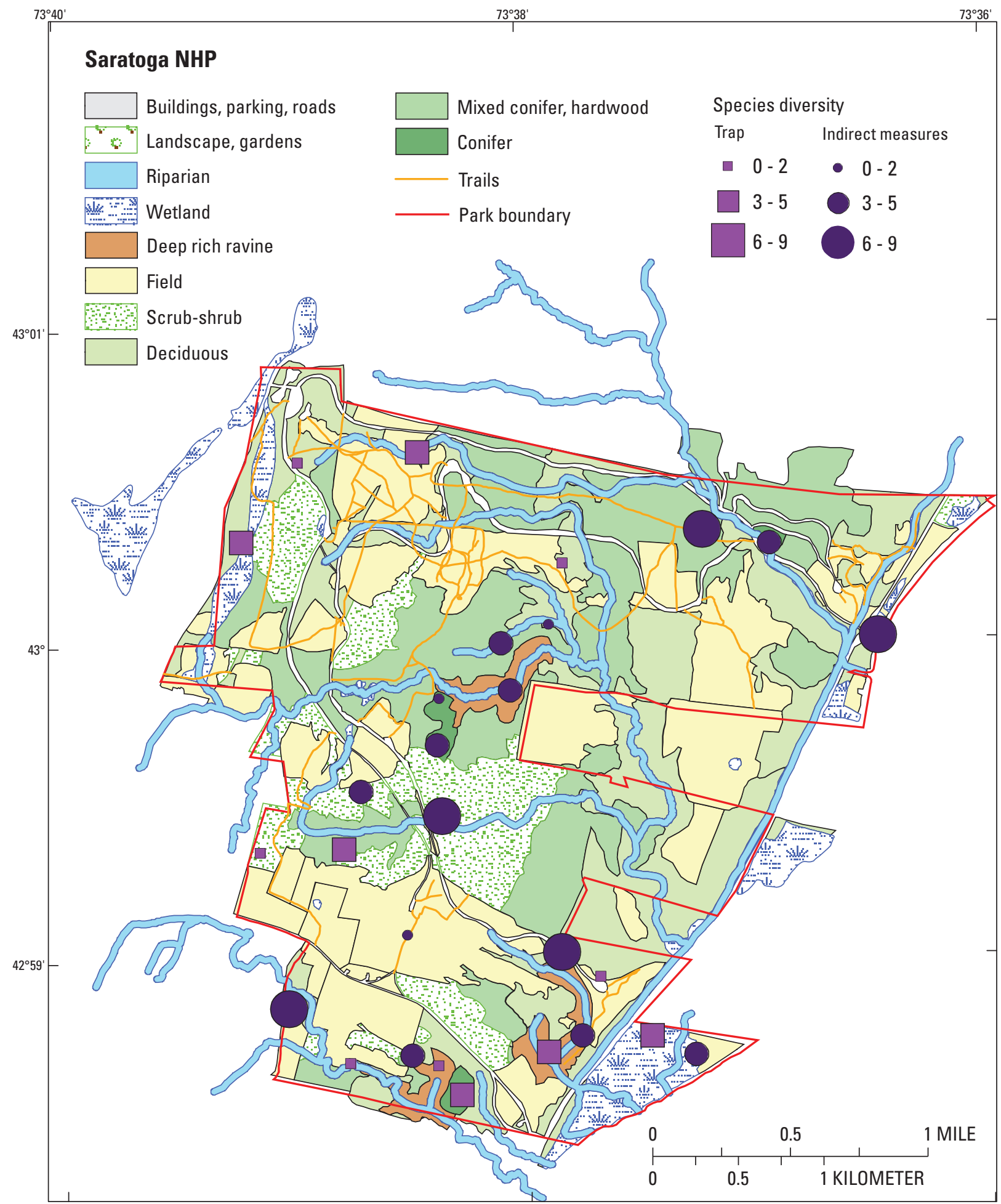

Prepared by: Andrew Gilbert, Patuxent Wildlife Research Center, U.S. Geological Survey, October 2007

Figure 29. Species diversity at trapping and indirect measure sampling stations during the 2004 mammal inventory at Saratoga National Historical Park. 
Table 46. Mammal specimens in museum collections and their proximity to Saratoga National Historical Park.

[Proximity-to-park codes: 1, collected within park boundaries; 2, collected in the town (Saratoga, Schuylerville, N.Y.) the park is located in; 3, collected in the county (Saratoga) the park is located in. Institutions: CM, Carnegie Museum of Natural History; CUMV, Cornell University Museum of Vertebrates; FMNH, Field Museum of Natural History; MSB, Museum of Southwestern Biology; NMNH, Smithsonian Institution, National Museum of Natural History; NYSM,

New York State Museum. -, no specimens]

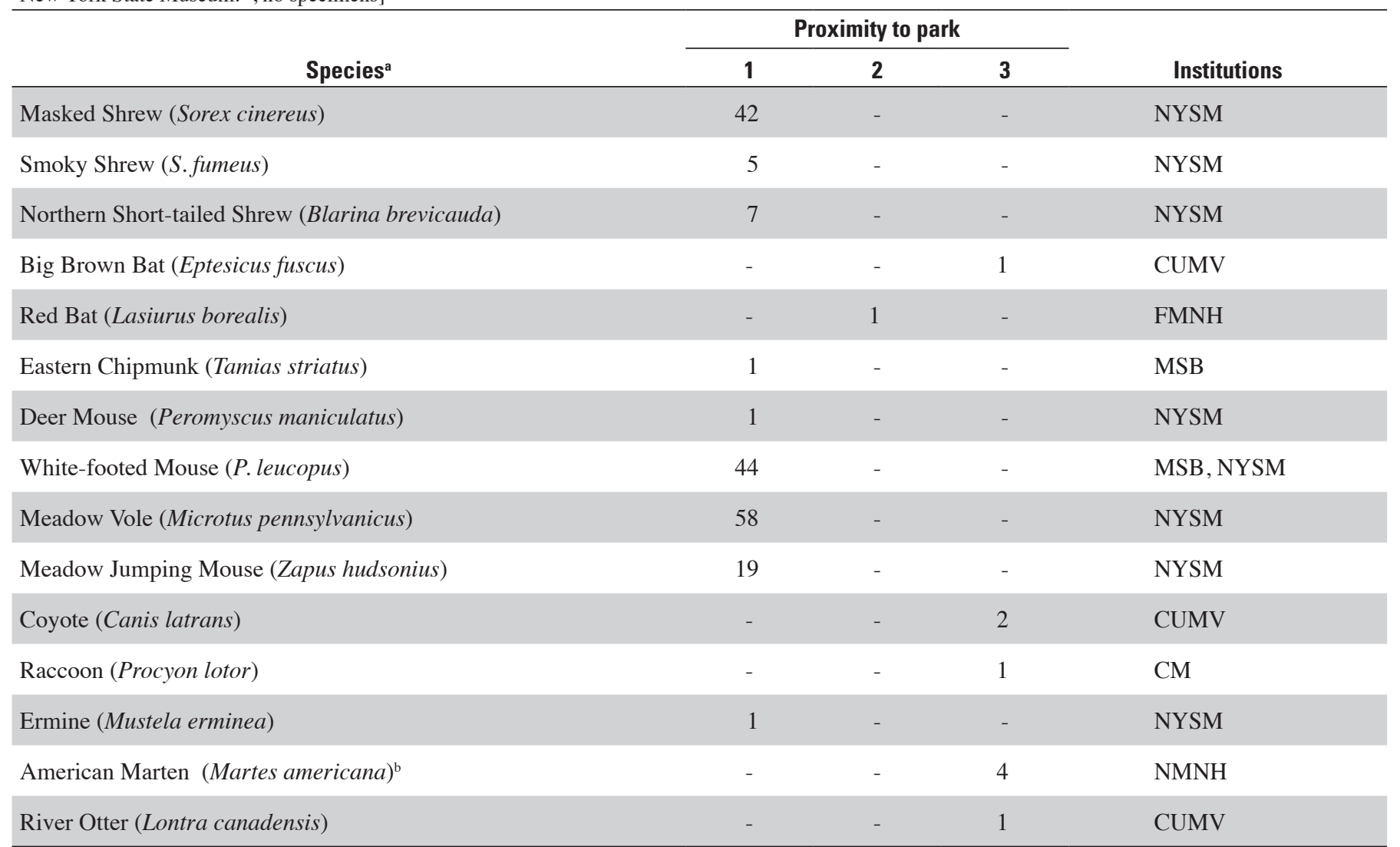

a Specimen data available through the National Park Service, NPSpecies database. For more information see: Gilbert and O'Connell, 2004; O'Connell and others, 2004; and A.F. O'Connell and A.T. Gilbert, unpublished data available at the USGS Patuxent Wildlife Research Center laboratory in Beltsville, Md.

${ }^{\mathrm{b}}$ These specimens were collected in 1943 from an experimental fur farm in Saratoga Springs, N.Y. 


\section{Acadia National Park (ACAD)}

\section{Background}

Acadia National Park (ACAD) is the largest and most diverse of the NETN Parks. Covering 19,229 ha, the park is spread among three main units in eastern coastal Maine: Mount Desert Island (MDI), Isle au Haut, and Schoodic Peninsula. The terrain consists of steep, rocky mountains that slope to a rocky shoreline. A large wildfire in 1947 burned nearly 20 percent of the park and altered vegetative succession, resulting in a great deal of hardwood forest on the eastern half of MDI. Elsewhere, spruce-fir forests dominate the landscape, particularly on the western half of MDI. Many streams flow through the park, beginning as mountain brooks or draining some of the many lakes and ponds that dot the landscape. In addition to the wooded upland portions of ACAD, 20 percent of the park's land area and vicinity is covered by wetland. Forested wetlands are the dominant wetland class in the park (Calhoun and others, 1994). ACAD is also unique in the large amount of tidal wetland and rocky shoreline. A system of carriage roads traverses the park, though much of the higher elevation areas can be reached only by foot trails.

\section{Prior Research}

Scientific investigations of mammals within and adjacent to ACAD date back to the early part of the $20^{\text {th }}$ century (table 47). Bailey (1925) and Stupka (1932-35) generated much of the early information on mammals, and Manville (1942) synthesized many of these earliest publications, collected specimens, and recounted the important species occurrences on MDI during the late 1930s. He updated that work in the 1950s (Manville, 1960), and collected information on mammals from Isle au Haut in the early 1960s (Manville, 1964). Some voucher specimens collected by Manville were deposited in collections at nationally known museums and at ACAD. Apparently, all voucher specimens held at ACAD

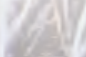



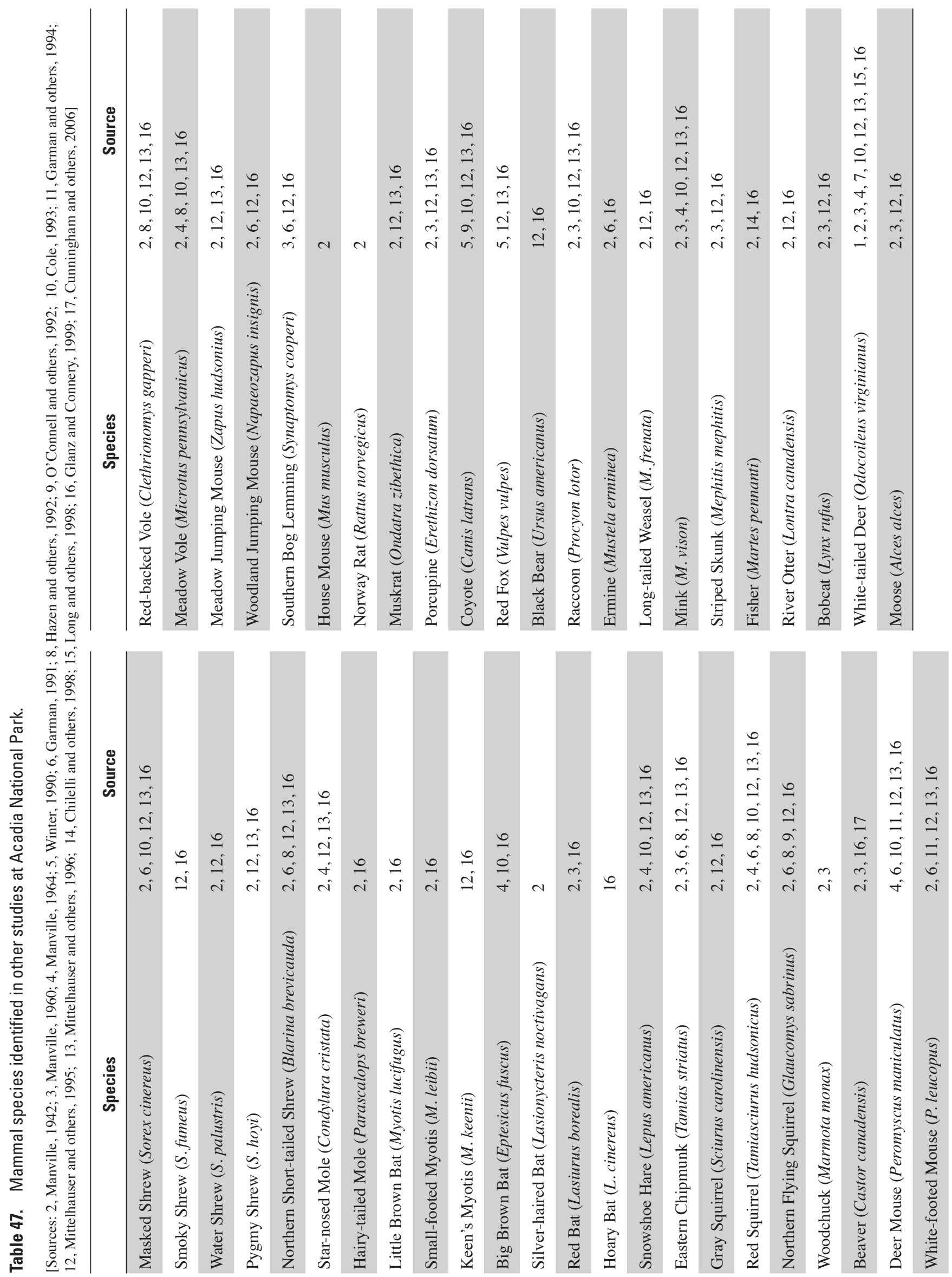


\section{Sampling Stations}

Indirect measure sampling at ACAD was conducted during a single session in April 2004. We selected 12 sampling locations in six community types. Initially, we had intended to trap during the second sampling session at ACAD, but we were unable to perform either IM sampling or trapping during the second sampling session because of budget constraints that were resolved too late in the year to complete field work safely and effectively. In consultation with park staff, we narrowed the range of community types sampled to those where little prior mammal work had occurred (table 48; figures 30-31).

\section{Survey Results}

Eight species were detected at ACAD: eight during indirect measure sampling and one by observation (table 49). This is 16 percent of the potential mammals that could occur in the park, excluding bats ( $\mathrm{N}=49$, table 1$)$. Raccoons (Procyon lotor) were the most frequently detected species (table 50) and most widely distributed (table 49), and Snowshoe Hare (Lepus americanus) was the second most commonly detected species. Because small mammals were not trapped at ACAD, we cannot report on their presence based on this work. Measured diversity was low at sampling stations (figs. 32-33), probably due, in part, to reduced sampling effort (no trapping and only one sampling session).

\section{Species Expected but Not Detected}

Manville (1942) reported that Fisher had been extirpated from MDI at the time of his initial survey and they have been considered absent from MDI during the remainder of the $20^{\text {th }}$ century. The last evidence for this species on MDI was a set of tracks from 1925 (Manville, 1942). Results of a recent modeling effort indicate that Fisher probably could not maintain a viable population on the Island (Chilelli and others, 1998), but according to recent reports from park staff, Fisher were recently observed on MDI and a specimen was collected near park headquarters (Bruce Connery, National Park Service, written commun., 2004). Given that the Fisher populations have increased across central and southern Maine in recent years, the likelihood that this mustelid can once again inhabit MDI is also increasing.

Mink (Mustela vison) and Striped Skunk (Mephitis mephitis) were not detected in this survey, but are thought to occur on MDI. Mink are associated closely with waterways and, if possible, do not stray far from water (Godin, 1977). Although we surveyed wetland communities where mink would be expected to occur, they are difficult to detect unless capture devices are set immediately along waterways and focused on them as a target species. The Sea Mink (Mustela macrodon), a larger relative of the Mink, once ranged over coast and islands of Maine from at least as far south as Casco Bay to the maritime provinces of Canada including the area around MDI, becoming extinct sometime in the late 1800s (Waters and Ray, 1961). Manville (1942) reports that skeletal remains of this species have been unearthed in Native American midden sites near MDI, evidence of their past presence on MDI. The Striped Skunk is a generalist predator and occurs in many different community types, preferring edge habitat and areas with constant food and water sources (Rosatte and Larivière, 2003). Voucher specimens exist for both these species (table 51) and these species were reported by Manville (1942) during his first study. His update in 1960 reported Mink as being seldom encountered, whereas Skunks were abundant.

Table 48. Indirect measure (IM) station numbers, community type, GPS locations of the camera at IM stations, and orientation of IM stations at Acadia National Park.

\begin{tabular}{ccllll}
\hline Station number & Station type & \multicolumn{1}{c}{ Community type } & UTM X & ${\text { UTM } \mathbf{~ Y}^{\mathbf{a}}}^{\mathbf{a}}$ & Orientation/bearing $^{\mathbf{b}}$ \\
\hline 5 & IM & shrubland deciduous wetland & 565230 & 4910481 & E-W \\
9 & IM & woodland conifer wetland & 551981 & 4903636 & E-W \\
17 & IM & woodland conifer wetland & 551588 & 4902307 & N-S \\
21 & IM & shrubland deciduous wetland & 551386 & 4902443 & E-W \\
41 & IM & deciduous woodland & 563369 & 4912586 & E-W $^{\text {c }}$ \\
45 & IM & woodland conifer wetland & 560876 & 4914535 & E-W \\
57 & IM & woodland conifer wetland & 558295 & 4913505 & N-S \\
61 & IM & woodland conifer wetland & 550208 & 4903450 & N-S \\
65 & IM & woodland conifer wetland & 549215 & 4903762 & E-W \\
69 & IM & dwarf shrubland evergreen wetland & 560353 & 4914769 & E-W \\
81 & IM & blueberry bald mountain summit & 557047 & 4909429 & E-W \\
85 & IM & blueberry bald mountain summit & 557915 & 4910769 & E-W \\
\hline
\end{tabular}

a Universal Transverse Mercator Zone 19; datum, North American Datum 1983; units, meters.

$\mathrm{b}$ The orientation of the trackplates relative to the cameras in the IM station.

c No camera present at this array, coordinates given for the middle of the array. 


\section{Acadia National Park - MDI West}

Land use
Cultural vegetation
Graminoid upland
Sparse vascular upland
Nonvegetated water or forb wetland
Tidal zone
Graminoid wetland

Shrubland deciduous wetland
Forest deciduous wetland
Woodland conifer wetland
Dwarf shrubland evergreen wetland
Dwarf shrubland evergreen upland
Dwarf shrubland deciduous upland
Deciduous upland

Mixed upland
Conifer upland
Small island
— Park boundary (fee land)
Active infrared camera
P Passive infrared camera
$\mathbf{9}$ Station number

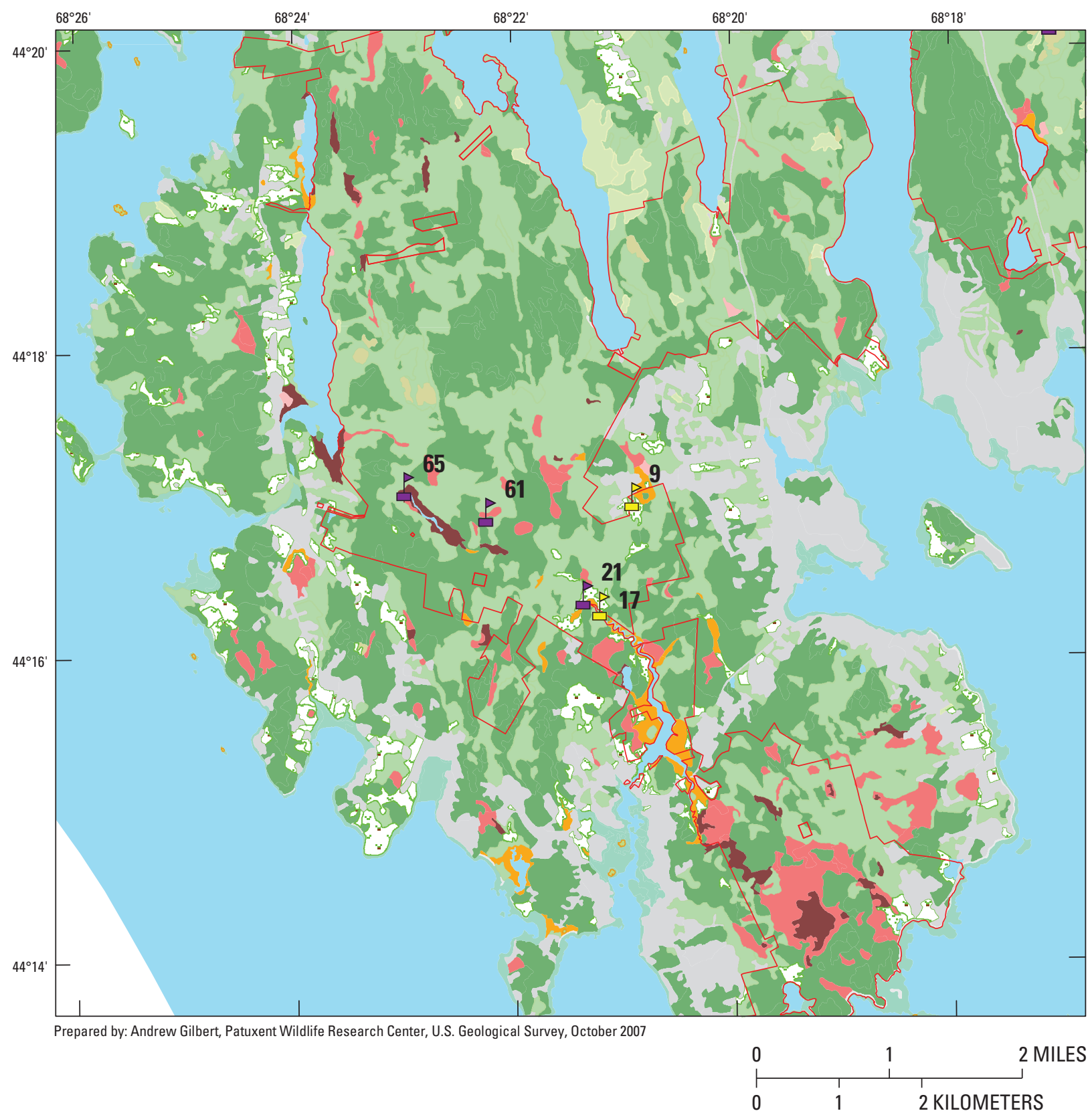

Figure 30. Locations of remote cameras and other detection devices used in the 2004 mammal inventory at Acadia National Park (Mount Desert Island - west). (Two trackplates and two hair traps were arranged about 50 meters from each camera location. Station numbers are provided for sampling arrays.) 


\section{Acadia National Park - MDI East}

Land use
Gultural vegetation
Graminoid upland
Sparse vascular upland
Nonvegetated water or forb wetland
Tidal zone
Graminoid wetland

Shrubland deciduous wetland
Forest deciduous wetland
Woodland conifer wetland
Dwarf shrubland evergreen wetland
Dwarf shrubland evergreen upland
Dwarf shrubland deciduous upland
Deciduous upland

Mixed upland
Conifer upland
Small island
_ Park boundary (fee land)
\& Active infrared camera
$\mathbf{4}$ Passive infrared camera
$\mathbf{4 5}$ Station number

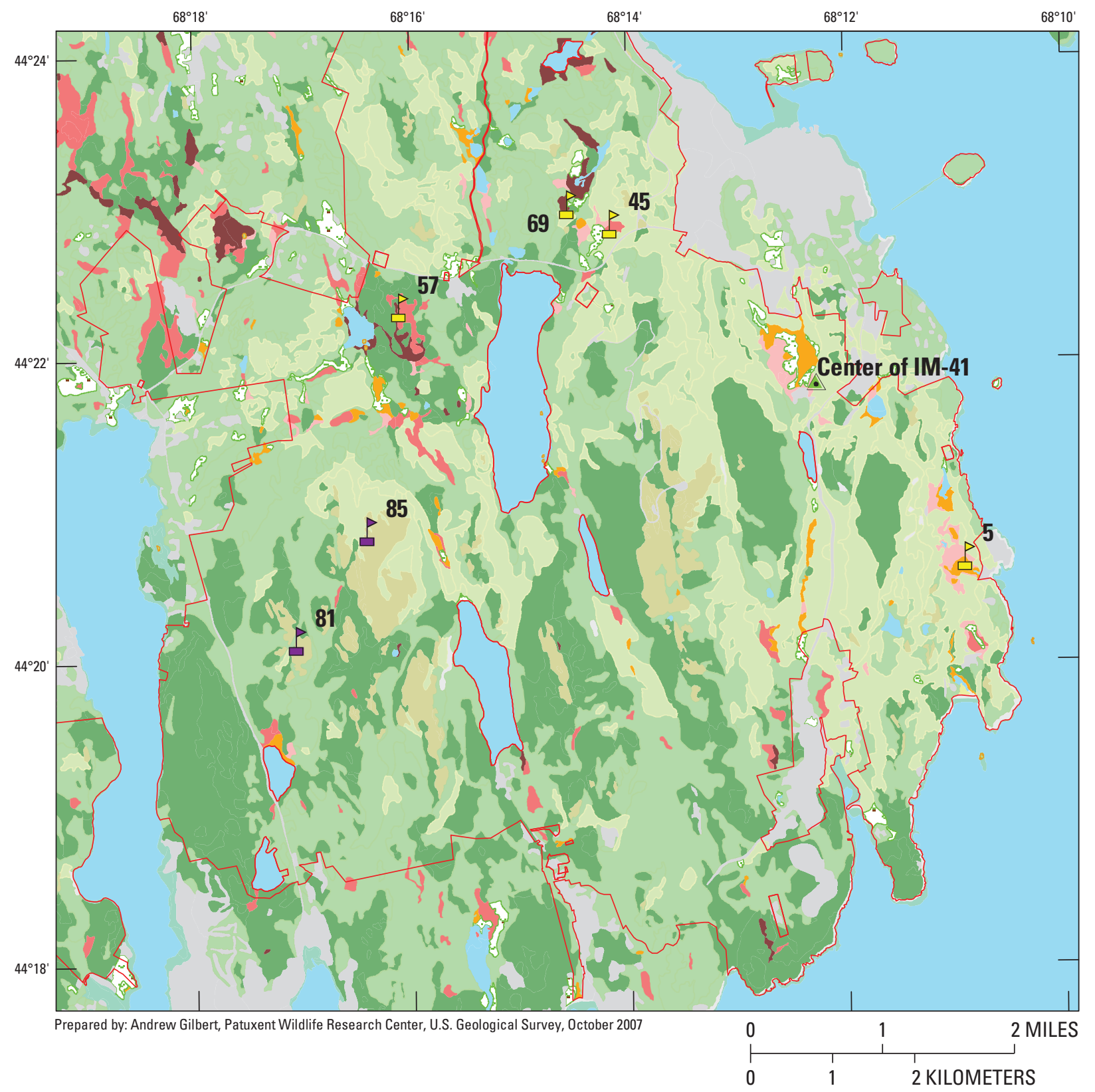

Figure 31. Locations of remote cameras and other detection devices used in the 2004 mammal inventory at Acadia National Park (Mount Desert Island - east). (Two trackplates and two hair traps were arranged about 50 meters from each camera location. Station numbers are provided for sampling arrays.) 
Table 49. Community type associations of mammals detected at Acadia National Park by indirect measure sampling, trapping, and observation.

[Community type associations are based on vegetation community descriptions of each sampling location. C, camera; TP, trackplate; TR, trapping; X, species observed for which we have records; -, not detected]

\begin{tabular}{|c|c|c|c|c|c|c|c|}
\hline \multirow[b]{2}{*}{ Species detected } & \multicolumn{6}{|c|}{ Community type } & \multirow[b]{2}{*}{ Observed } \\
\hline & $\begin{array}{l}\text { Blueberry } \\
\text { bald mountain } \\
\text { summit }\end{array}$ & Conifer & $\begin{array}{l}\text { Deciduous } \\
\text { woodland }\end{array}$ & $\begin{array}{c}\text { Dwarf } \\
\text { shrubland } \\
\text { evergreen } \\
\text { wetland }\end{array}$ & $\begin{array}{l}\text { Shrubland } \\
\text { deciduous } \\
\text { wetland }\end{array}$ & $\begin{array}{l}\text { Woodland } \\
\text { conifer } \\
\text { wetland }\end{array}$ & \\
\hline Shrew spp. & - & - & - & $\mathrm{TP}$ & $\mathrm{TP}$ & $\mathrm{TP}$ & - \\
\hline Squirrel spp. & - & - & - & $\mathrm{TP}$ & - & - & - \\
\hline Mouse/Vole/Shrew spp. & $\mathrm{TP}$ & - & - & $\mathrm{TP}$ & $\mathrm{TP}$ & - & - \\
\hline Porcupine & $\mathrm{C}$ & - & - & - & - & - & - \\
\hline Long-tailed Weasel/Ermine & - & - & - & - & - & $\mathrm{TP}$ & - \\
\hline Domestic Cat & - & - & - & - & - & $\mathrm{TP}$ & - \\
\hline White-tailed Deer & - & - & - & - & - & $\mathrm{C}$ & - \\
\hline Total species detected ${ }^{\mathrm{a}}$ & 2 & 1 & 1 & 3 & 3 & 6 & 1 \\
\hline
\end{tabular}

${ }^{a}$ Totals exclude generic counts unless no other species in that group were detected (for example, Shrew spp. would be counted if no other specific shrew was detected). 
Table 50. Mammal species detection rates and site occupancy at 12 indirect measure stations at Acadia National Park during one sampling session in 2004.

\begin{tabular}{|c|c|c|}
\hline \multirow[b]{2}{*}{ Species detected } & \multicolumn{2}{|c|}{$\begin{array}{c}\text { Session } 1 \\
(4 / 5 / 2004-4 / 19 / 2004)\end{array}$} \\
\hline & $\begin{array}{c}\text { Number of } \\
\text { stations } \\
\text { occupied } \\
\text { (proportion) }\end{array}$ & $\begin{array}{c}\text { Mean } \\
\text { detection rate } \\
(\mathrm{SE})^{\mathrm{a}}\end{array}$ \\
\hline Shrew spp. & $3(0.25)$ & $0.05(0.03)$ \\
\hline Snowshoe Hare & $6(0.50)$ & $0.10(0.03)$ \\
\hline Northern Flying Squirrel & $1(0.08)$ & $0.02(0.02)$ \\
\hline Squirrel spp. & $1(0.08)$ & $0.02(0.02)$ \\
\hline Mouse/Vole/Shrew spp. & $3(0.25)$ & $0.05(0.03)$ \\
\hline Porcupine & $1(0.08)$ & $0.02(0.02)$ \\
\hline Raccoon & $8(0.67)$ & $0.32(0.10)$ \\
\hline Ermine & $1(0.08)$ & $0.02(0.02)$ \\
\hline Long-tailed Weasel/Ermine & $1(0.08)$ & $0.02(0.02)$ \\
\hline Domestic Cat & $1(0.08)$ & $0.02(0.02)$ \\
\hline White-tailed Deer & $1(0.08)$ & $0.02(0.02)$ \\
\hline \multicolumn{3}{|c|}{$\begin{array}{l}\text { a The mean rate of detection and standard error over all stations, includ- } \\
\text { ing those stations where the species was not detected (detection rate }=0 \text { ). } \\
\text { Species detection rates were calculated for each station by dividing the total } \\
\text { number of individual species detections for all checks at a station (camera } \\
\text { and trackplate only) by the number of checks made at that station. SE, the } \\
\text { standard error of this mean. }\end{array}$} \\
\hline
\end{tabular}

Chipmunk (Tamias striatus), Gray Squirrel (Sciurus carolinensis), and Red Squirrel (Tamiasciurus hudsonicus) were noticeably absent from this study, but are known to occur on MDI. Chipmunks and Red Squirrels are abundant in the boreal forest, and the Gray Squirrel, are locally common in deciduous upland forests, especially oak woodlands (Bruce Connery, National Park Service, oral commun., 2006). Due to limited resources, we sampled only in wetland and mountain summit communities, two community types where these species probably do not occur. Gray Squirrels were believed to have been decimated by the 1947 fire (Manville, 1960) and may have been less common across the island since that time. Red Squirrel and Chipmunk vouchers are plentiful in museum collections from ACAD, whereas few Gray Squirrel specimens exist (table 51). We did not trap small mammals during this study, but they have been the focus of previous work on MDI over the years (Garman, 1991; Hazen and others, 1992; Garman and others, 1994; O'Connell and others, 2001) and the smallmammal fauna are fairly well known.

\section{Endangered and Threatened Species}

We did not detect any mammals that are listed as state or federally endangered or threatened. The State of Maine lists only the Northern Bog Lemming (Synaptomys borealis) as state endangered. The Gray Wolf (Canis lupus) and the Eastern Cougar (Puma concolor couguar) are listed as federally endangered, and the Canada Lynx (Felis canadensis) is listed as federally threatened (Maine Department of Inland Fisheries and Wildlife, 2006).

As noted previously, we did not trap small mammals at ACAD during this study and so were unable to detect the Northern Bog Lemming. The distribution of the Northern Bog Lemming seems to be confined to Northern Maine, and very few animals have been captured (Whitaker and Hamilton, 1998). The Northern Bog Lemming is not likely to be resident anywhere near ACAD.

The Gray Wolf and Eastern Cougar were extirpated from Maine by the early 1900s (Goodwin, 1936; Cardoza and Langlois, 2002) and their future existence in ACAD is unlikely unless they species are reintroduced or recolonize. There continues to be interest by a coalition of northeastern conservation groups in active recovery (reintroduction) of wolves into remote sections of Maine as part of a recovery plan for this species in the eastern U.S. (Coalition to Restore the Eastern Wolf, 2006). Although potential wolf habitat occurs in eastern Maine, high road and human population densities could be a barrier to colonization (Harrison and Chapin, 1997), precluding the wolf's natural recolonization of MDI. Thus, it is unlikely that wolves will ever occur again anywhere in ACAD. Eastern Cougar sign (visual reports, tracks, hairs) has been reported thousands of times throughout the eastern U.S. but few reports offer sufficient documentation to support the existence of this species (Cardoza and Langlois, 2002). The large number of reports indicates that there may be a remnant population, but standardized surveys are required to confirm their existence (Cardoza and Langlois, 2002). Maine Department of Inland Fisheries and Wildlife (2003) does not believe that a breeding population of this species exists in Maine and that reports of this species, particularly in urban and coastal regions, are of escaped pets. It is unlikely that this species will ever occur in ACAD without an active recovery effort.

The Canada Lynx is now known to occur and breed in far northern Maine. A few records of Lynx exist from the period 1973-99 for the coastal region of Maine just north of the Schoodic Peninsula (Hoving and others, 2003). Manville (1942) writes that this species was likely extirpated from MDI many years prior to his work. Canada Lynx inhabit areas of deep snow through which they can pursue their preferred prey, Snowshoe Hare (Whitaker and Hamilton, 1998; Hoving and others, 2005) and, results of recent modeling efforts have shown that Lynx are unlikely to occur in areas with less than $270 \mathrm{~cm} / \mathrm{yr}$ of snow or areas dominated by deciduous forest (Hoving and others, 2005). Total annual snowfall at ACAD averaged $156 \mathrm{~cm}$ during 1940-85 (National Park Service, 2006), but snowfall in recent years has been even less than that (Bruce Connery, National Park Service, oral commun., 2006). Therefore, Lynx probably do not inhabit ACAD. However, if the population of Lynx in Maine increases, dispersing Lynx may be encountered again in the Schoodic region. 
Table 51. Number of mammal specimens in museum collections and their proximity to Acadia National Park.

[Proximity-to-park codes: 1, collected within park boundaries; 2, collected in the town (Bar Harbor, Isle au Haut, Mount Desert, Southwest Harbor, Tremont, Maine) the park is located in. 3, collected in the county (Hancock) the park is located in; Institutions: AMNH, American Museum of Natural History; BSNS, Buffalo Museum of Science; COA, College of the Atlantic; CUMV, Cornell University Museum of Vertebrates; MCZ, Harvard University, Museum of Comparative Zoology; MSB, Museum of Southwestern Biology; NMNH, Smithsonian Institution, National Museum of Natural History; TTU, Texas Tech University; UMMZ, University of Michigan Museum of Zoology; YPM, Yale University, Peabody Museum. -, no specimens]

\begin{tabular}{|c|c|c|c|c|}
\hline \multirow{2}{*}{ Species $^{\mathrm{a}}$} & \multicolumn{3}{|c|}{ Proximity to park } & \multirow{2}{*}{ Institutions } \\
\hline & 1 & 2 & 3 & \\
\hline Masked Shrew (Sorex cinereus) & 1 & 10 & 5 & BSNS, MCZ, NMNH, UMMZ, YPM \\
\hline Northern Short-tailed Shrew (Blarina brevicauda) & 3 & 20 & 6 & AMNH, CUMV, MCZ, TTU, NMNH, UMMZ, YPM \\
\hline Star-nosed Mole (Condylura cristata) & 1 & 3 & - & COA, MCZ, UMMZ \\
\hline Small-footed Myotis (M. leibii) & 1 & 4 & - & MCZ, UMMZ \\
\hline Big Brown Bat (Eptesicus fuscus) & - & 12 & - & $\mathrm{MCZ}$ \\
\hline Silver-haired Bat (Lasionycteris noctivagans) & - & 2 & - & $\mathrm{MCZ}$ \\
\hline Red Bat (Lasiurus borealis) & - & 1 & - & $\mathrm{MCZ}$ \\
\hline Snowshoe Hare (Lepus americanus) & 2 & 7 & 2 & COA, MCZ, MSB, TTU, NMNH, UMMZ \\
\hline Northern Flying Squirrel (Glaucomys sabrinus) & - & 2 & - & $\mathrm{MCZ}$ \\
\hline Beaver (Castor canadensis) & - & 1 & - & $\mathrm{MCZ}$ \\
\hline Deer Mouse (Peromyscus maniculatus) & 16 & 23 & 14 & MCZ, NMNH, UMMZ \\
\hline White-footed Mouse (P. leucopus) & 40 & & & MSB \\
\hline Deer or White-footed Mouse (Peromyscus spp.) & - & & 4 & AMNH \\
\hline Red-backed Vole (Clethrionomys gapperi) & 13 & 28 & 1 & AMNH, MCZ, MSB, NMNH, UMMZ, YPM \\
\hline Meadow Vole (Microtus pennsylvanicus) & 10 & 25 & 23 & AMNH, MCZ, NMNH, UMMZ \\
\hline Vole sp. & - & 1 & - & TTU \\
\hline Raccoon (Procyon lotor) & - & 1 & - & $\mathrm{MCZ}$ \\
\hline Ermine (Mustela erminea) & 1 & 1 & 1 & COA, UMMZ, UNSM \\
\hline Long-tailed Weasel (M.frenata) & - & - & 1 & FMNH \\
\hline Mink (M. vison) & - & 4 & - & $\mathrm{MCZ}$ \\
\hline Sea Mink (M. macrodon) & - & 1 & - & $\mathrm{MCZ}$ \\
\hline Striped Skunk (Mephitis mephitis) & 1 & - & 1 & FMNH, UMMZ \\
\hline Fisher (Martes pennanti) & - & 1 & 4 & CUMV, UNSM \\
\hline River Otter (Lontra canadensis) & - & 1 & - & $\mathrm{MCZ}$ \\
\hline Bobcat (Lynx rufus) & - & - & 2 & FMNH \\
\hline White-tailed Deer (Odocoileus virginianus) & 1 & - & - & NMNH \\
\hline
\end{tabular}

${ }^{\text {a }}$ Specimen data available through the National Park Service, NPSpecies database. For more information see: Gilbert and O'Connell, 2004; O'Connell and others, 2004; and A.F. O'Connell and A.T. Gilbert, unpublished data available at the USGS Patuxent Wildlife Research Center laboratory in Beltsville, Md. 


\section{Acadia National Park - MDI West}

Land use
Cultural vegetation
Graminoid upland
Sparse vascular upland
Nonvegetated water or forb wetland
Tidal zone
Graminoid wetland

Shrubland deciduous wetland
Forest deciduous wetland
Woodland conifer wetland
Dwarf shrubland evergreen wetland
Dwarf shrubland evergreen upland
Dwarf shrubland deciduous upland
Deciduous upland
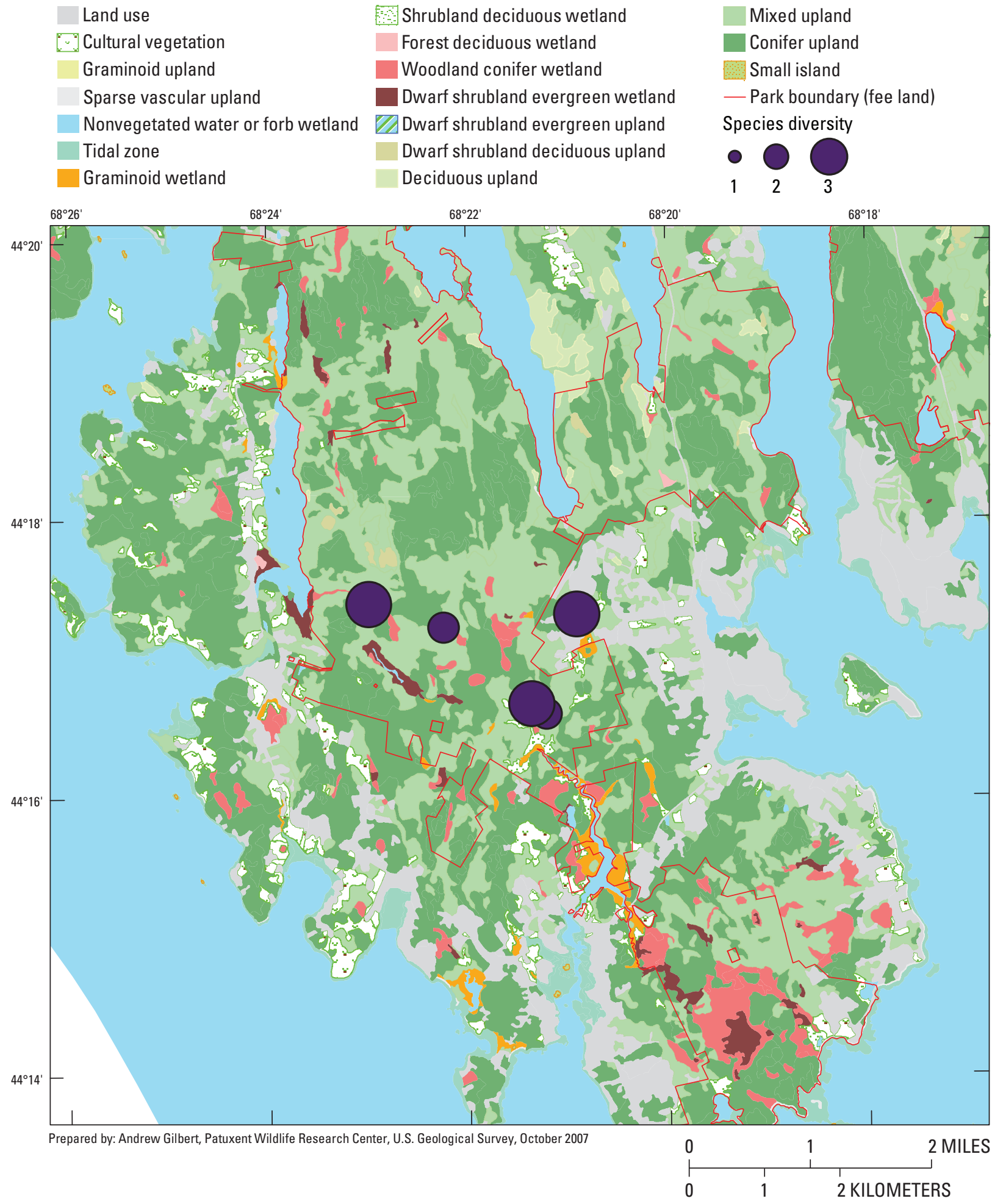

Figure 32. Species diversity at indirect measure sampling stations during the 2004 mammal inventory at Acadia National Park (Mount Desert Island - west). 


\section{Acadia National Park - MDI East}

Land use
Graminoid upland
Sparse vascular upland
Nonvegetated water or forb wetland
Tidal zone
Graminoid wetland

Shrubland deciduous wetland
Forest deciduous wetland
Woodland conifer wetland
Dwarf shrubland evergreen wetland
Dwarf shrubland evergreen upland
Dwarf shrubland deciduous upland
Deciduous upland
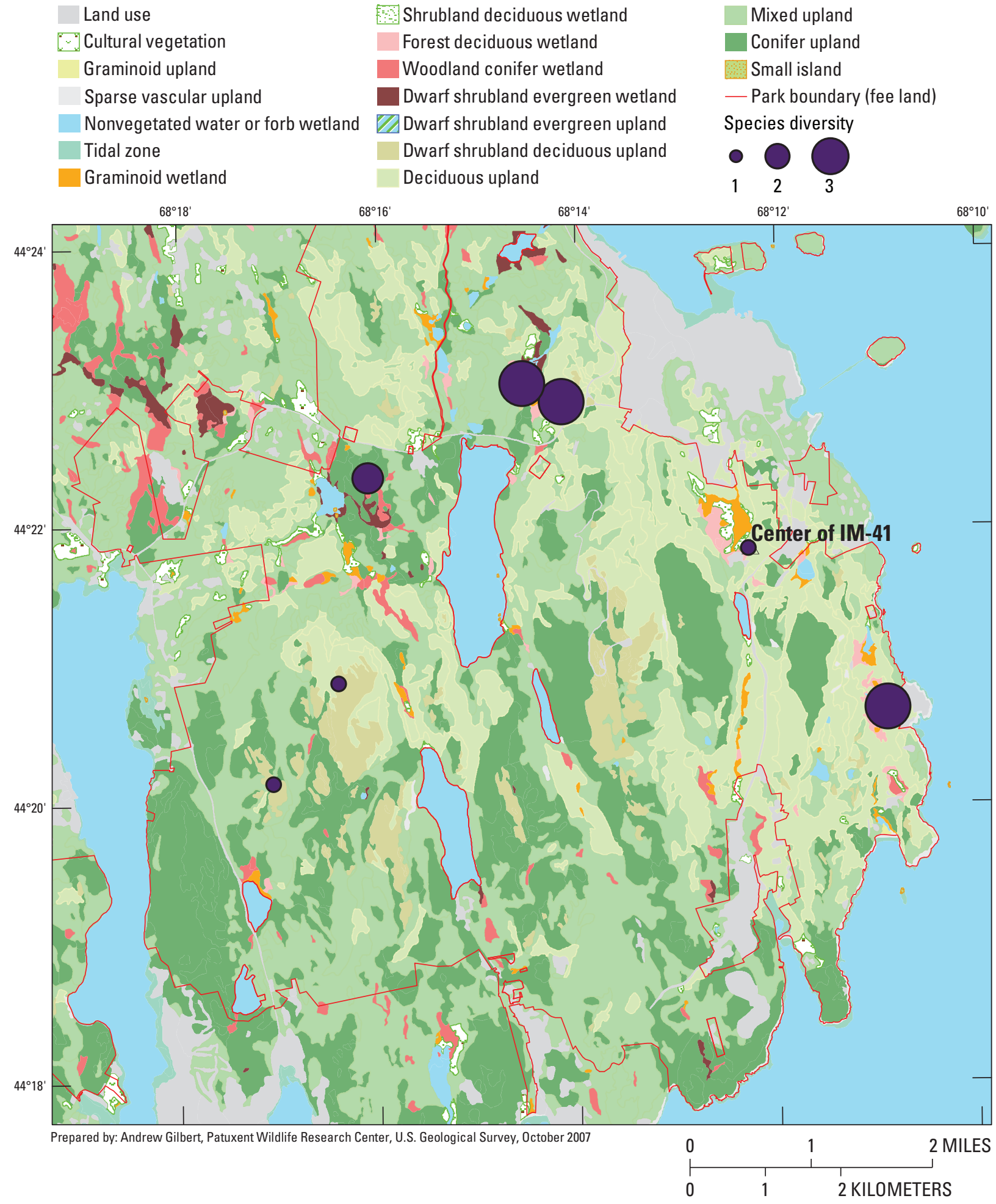

Figure 33. Species diversity at indirect measure sampling stations during the 2004 mammal inventory at Acadia National Park (Mount Desert Island - east). 


\section{Sagamore Hill National Historic Site (SAHI)}

\section{Background}

Sagamore Hill National Historic Site (SAHI) was Theodore Roosevelt's summer retreat on Oyster Bay, located in a suburban area on the northern edge of Long Island, New York. The park is small ( $36 \mathrm{ha}$ ) and consists mostly of central hardwood forest. Oyster Bay bounds the park to the east and includes sandy beaches and small tidal areas. The Roosevelt home in the western portion of the park overlooks a maintained field. Two small freshwater wetlands also occur in the park.

\section{Prior Investigations}

No known work on mammals has been conducted at SAHI.

\section{Sampling Stations}

Indirect measure sampling was conducted in April/ May and November 2004 and trapping was conducted only in November 2004. We selected 14 locations for sampling (7 IM and 7 trap) in six community types prior to beginning field work (table 52; fig. 34). This was many fewer sampling stations than were selected (24 stations). Sagamore Hill NHS is small, but with a diverse array of community types. Consequently, many of the locations selected for sampling were very close to other stations, which would lead to a high degree of overlap if we placed equipment at all stations. We selected (non-randomly) sampling points that were generated from the original systematic, random start design to maximize the distance between stations and still maintain as many points in different strata as possible. The number of sampling stations in the maritime-dunes, saltmarsh-panne complex, scrub-shrub, and field strata was reduced to less than four stations in each stratum.

\section{Survey Results}

Eight species were detected at SAHI during this inventory: eight during IM sampling and five during trapping (table 53). This is 15 percent of the potential number of mammal species that could occur in the park $(\mathrm{N}=55$, table 1$)$, excluding bats. Raccoons (Procyon lotor) were the most frequently detected species during both sampling sessions (table 54). Raccoons were detected throughout the park in all community types (table 53). The Virginia Opossum (Didelphis virginiana) was the next most frequently detected species, and was found in all areas with trees. The Domestic Cat (Felis silvestris) was detected in all but beach and saltmarsh community types (table 53).

The diversity of small mammals detected was low, despite a large number of traps relative to the size of the park. The White-footed Mouse (Peromyscus leucopus) was the most frequently captured small mammal, followed closely by Northern Short-tailed Shrew (Blarina brevicauda) (table 55).

Species diversity varied among community types between two and seven species detected (table 53), but no geographic area of the park appeared to be more diverse than any other (fig. 35). Generally, more species were detected in the forested community (table 53); however, forest dominates the landscape at SAHI and less equipment was located in other community types.

\section{Species Expected but Not Detected}

Sorex spp. shrews were not captured in this study, but the Masked Shrew (S. cinereus) has been documented in Nassau County (table 56). Shrews were not well documented in this inventory because we did not use pitfall traps. (For a detailed

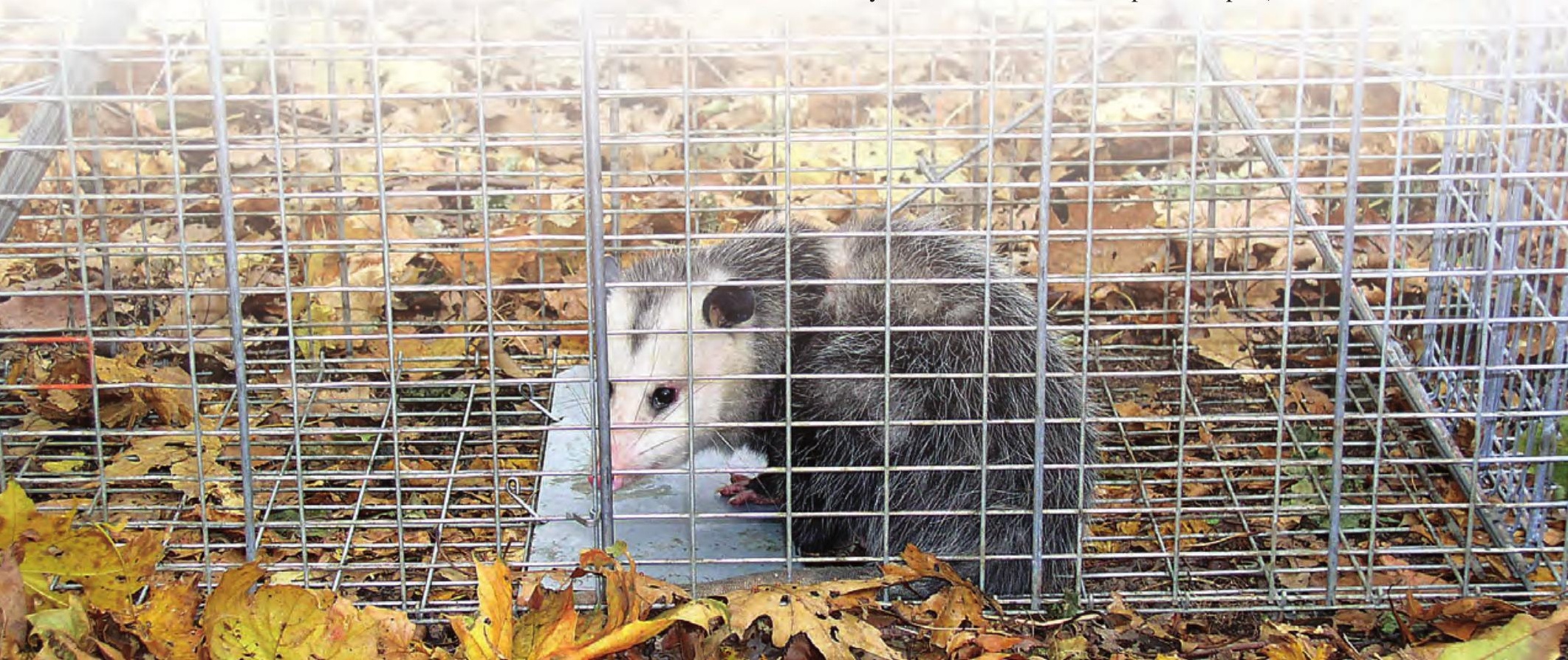


Table 52. Indirect measure (IM) and trap station numbers, community type, GPS locations of the camera at IM stations and beginning of the Longworth trap lines, orientation of IM stations, and bearing of trap lines at Sagamore Hill National Historic Site.

\begin{tabular}{cclccc}
\hline Station number & Station type & \multicolumn{1}{c}{ Community type } & UTM $\mathbf{X}^{\mathbf{a}}$ & UTM Y $^{\mathbf{a}}$ & Orientation/bearing $^{\mathbf{b}}$ \\
\hline 5 & Trap & saltmarsh panne complex & 627161 & 4527225 & $180^{\circ}$ \\
\hline 9 & IM & saltmarsh panne complex & 627112 & 4527046 & SE-NW \\
12 & Trap & field & 626248 & 4527061 & $315^{\circ}$ \\
\hline 18 & IM & norway maple & 626146 & 4527222 & SE-NW \\
25 & Trap & scrub-shrub & 626469 & 4527174 & $160^{\circ}$ \\
\hline 28 & IM & scrub-shrub & 626534 & 4527154 & NE-SW \\
\hline 30 & IM & norway maple & 626285 & 4527335 & E-W \\
\hline 34 & nM & norway maple & 626195 & 4527010 & E-W \\
\hline 38 & Trap & norway maple & 626227 & 4527038 & $225^{\circ}$ \\
43 & Trap & norway maple & 626122 & 4527146 & $20^{\circ}$ \\
46 & IM & beech-maple mesic & 627028 & 4527218 & NE-SW \\
\hline 50 & IM & beech-maple mesic & 626793 & 4527078 & E-W \\
\hline 54 & Trap & beech-maple mesic & 627014 & 4527187 & $270^{\circ}$ \\
\hline 59 & Trap & beech-maple mesic & 626620 & 4527097 & $90^{\circ}$ \\
\hline
\end{tabular}

${ }^{a}$ Universal Transverse Mercator Zone 18; datum, North American Datum 1983; units, meters.

${ }^{\mathrm{b}}$ The orientation of the trackplates relative to the cameras in the IM station or the bearing of the trap lines.

explanation of this issue, please refer to the Trapping section on p. 13.) There is no reason to believe that Masked Shrew does not occur at SAHI, but additional field work would be required to document their presence.

We did not capture or observe Moles at SAHI, but specimens of Star-nosed Mole (Condylura cristata) and Eastern Mole (Scalopus aquaticus) occur for Nassau County (table 56) (Connor, 1971). Moles are primarily fossorial, preferring to tunnel underground for food, although the Star-nosed Mole also makes use of wet areas such as wet meadows, swamps, and streams to feed (Whitaker and Hamilton, 1998). Moles are not routinely captured in small-mammal traps and we did not expect to capture them in this inventory. Moles occur where they can dig mounded tunnels in soil, such as in landscaped areas and forest trails.

We expected to capture Meadow Voles (Microtus pennsylvanicus) at the fields in SAHI, but did not. The fields had been cut prior to trapping, which may have forced Meadow Voles to move to areas of greater cover (LoBue and Darnell, 1959). Also, populations of this species are cyclical, resulting in low population levels in some years (Ostfeld and Canham, 1995, and references therein). Many Meadow Vole vouchers occur for Nassau County and this species is common on Long Island (Connor, 1971). Therefore, this species almost certainly occurs within the park, but went undetected during the brief trapping period.

\section{Endangered and Threatened Species}

We did not detect any species that were listed as state or federally threatened or endangered. The State of New York lists the Indiana Bat (Myotis sodalis), Allegheny Woodrat (Neotoma magister), Gray Wolf (Canis lupus), and Eastern Cougar (Felis concolor cougar) as endangered and the Canada Lynx (Lynx canadensis) as threatened. However, only the Indiana Bat has not been extirpated from New York (New York State Department of Environmental Conservation, 2005f). Small-footed Myotis (Myotis leibii) and New England Cottontail (Sylvilagus transitionalis) are listed as species of special concern.

Indiana Bats are known to occur in eastern New York and have been documented wintering in eight hibernacula in upstate New York: Albany, Essex, Warren, Jefferson, Onondaga, and Ulster Counties (New York State Department of Environmental Conservation, 2005e). Indiana Bats prefer riparian and floodplain trees (Thomson, 1982). Maternity roosts are found under the loose bark of trees and this species has been known to use elms, oaks, hickories, Cottonwood (Populus deltoides), Silver Maple (Acer saccharinum), and Green Ash (Fraxinus pennsylvanica) (Kurta and others, 1993). Although some of these trees are present at SAHI, the occurrence of Indiana Bats is unlikely given the lack of a riparian area and the distance from known hibernacula. We did not 

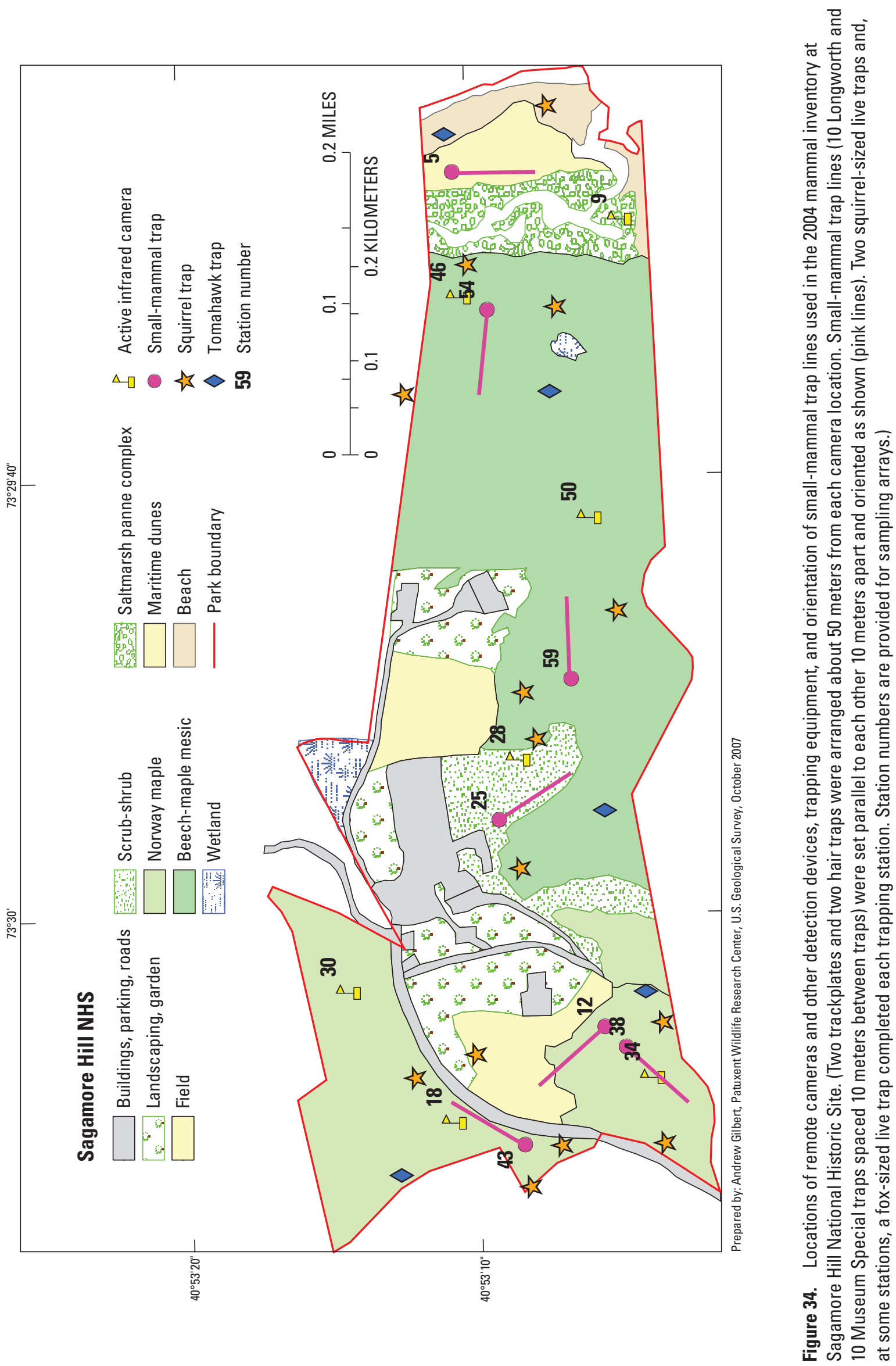
Table 53. Community type associations of mammals detected at Sagamore Hill National Historic Site by indirect measure sampling, trapping, and observation.

[Community type associations are based on vegetation community descriptions of each sampling location. C, camera; TP, trackplate; TR, trapping; X, species observed for which we have records; -, not detected]

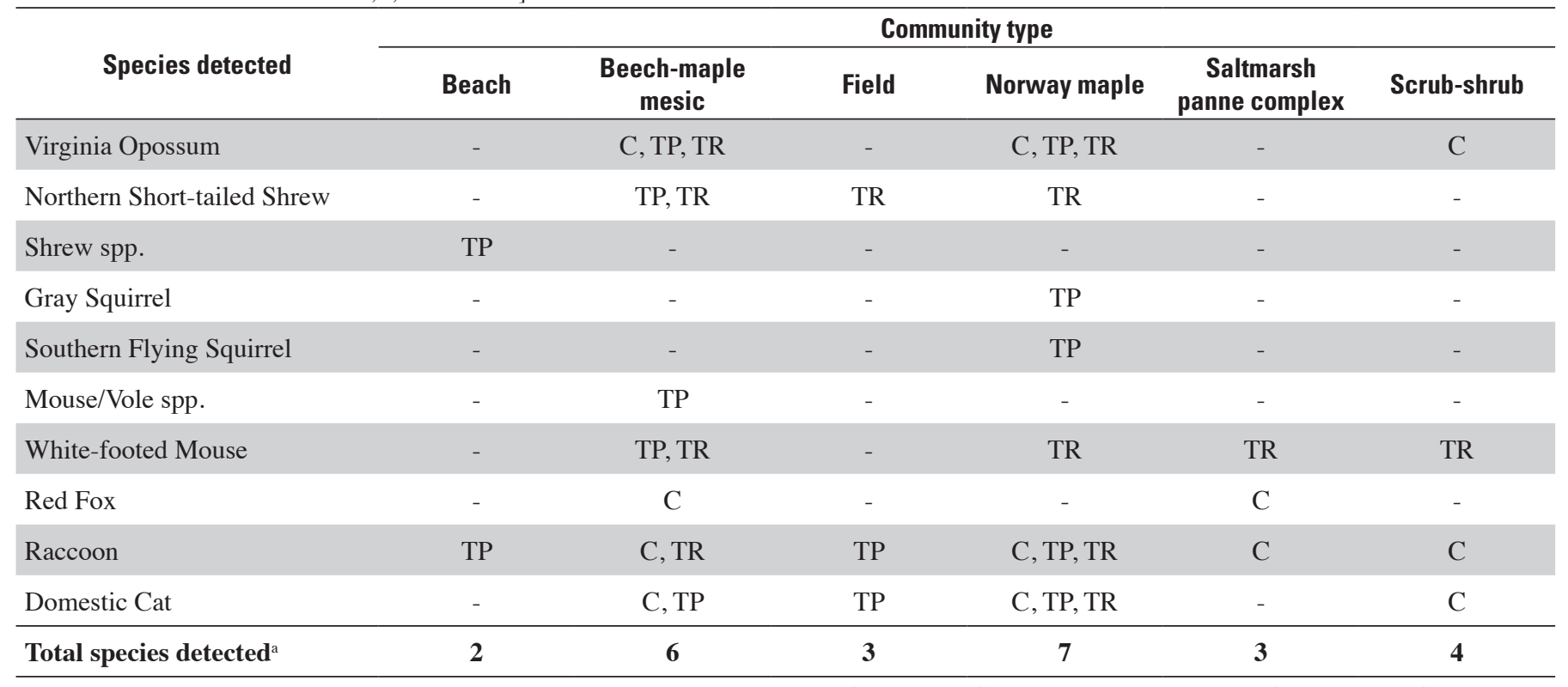

${ }^{\text {a }}$ Totals exclude generic counts unless no other species in that group were detected (for example, Shrew spp. would be counted if no other specific shrew was detected).

Table 54. Mammal species detection rates and site occupancy at seven indirect measure stations at Sagamore Hill National Historic Site during two sampling sessions in 2004.

$\underline{[-, \text { species not detected }]}$

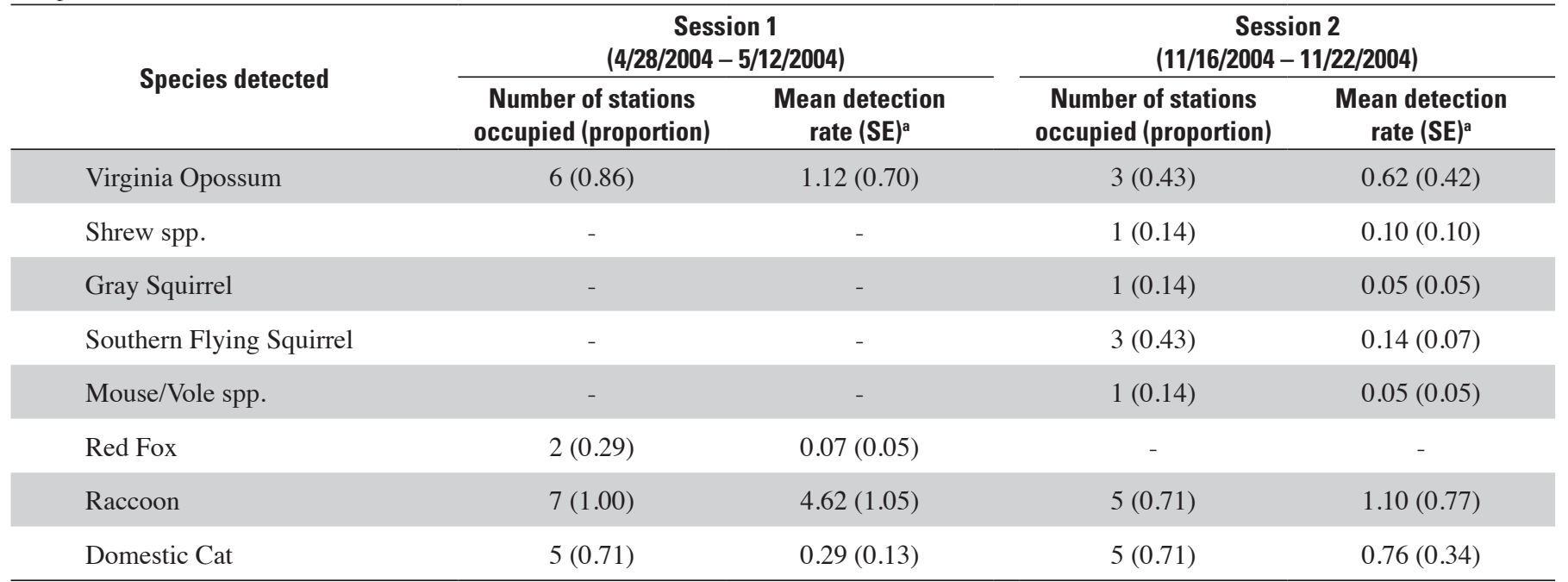

${ }^{a}$ The mean rate of detection and standard error over all stations, including those stations where the species was not detected (detection rate $=0$ ). Species detection rates were calculated for each station by dividing the total number of individual species detections for all checks at a station (camera and trackplate only) by the number of checks made at that station. SE, the standard error of the mean. 
Table 55. Mammal capture rates and site occupancy for seven trapping stations (four with fox-sized live traps) at Sagamore Hill National Historic Site during sampling session 2 (11/16/2004-11/23/2004).

\begin{tabular}{lccc}
\hline \multicolumn{1}{|c}{ Species detected } & $\begin{array}{c}\text { Number } \\
\text { of new } \\
\text { captures }\end{array}$ & $\begin{array}{c}\text { Number of } \\
\text { stations } \\
\text { occupied } \\
\text { (proportion) }\end{array}$ & $\begin{array}{c}\text { Mean rate } \\
\text { of new } \\
\text { individuals } \\
\text { captured (SE) }\end{array}$ \\
\hline Virginia Opossum & 3 & $3(0.60)$ & $0.10(0.04)$ \\
\hline $\begin{array}{l}\text { Northern Short-tailed } \\
\text { Shrew }\end{array}$ & 11 & $3(0.43)$ & $0.26(0.14)$ \\
$\begin{array}{l}\text { White-footed Mouse } \\
\text { Raccoon }\end{array}$ & 19 & $5(0.71)$ & $0.45(0.15)$ \\
\hline Domestic Cat & 3 & $2(0.40)$ & $0.10(0.06)$ \\
\hline
\end{tabular}

a Small-mammal and squirrel-sized live traps were placed at all seven stations whereas fox-sized live traps were set at only five; therefore, the number of stations at which medium-sized mammals (Domestic Cat, Raccoon, Virginia Opossum) could be captured was reduced to five for individual species for each night of sampling.

${ }^{\mathrm{b}}$ Rates were calculated for each station by dividing the total number of new individuals captured (per species) by the number of nights that traps were operational. SE, standard error of the mean.

survey bats in this study, and do not have any evidence that this species occurs in the park.

Allegheny Woodrats were once found on cliffs and talus slopes of southeastern New York, but were extirpated from the state by 1987 (New York State Department of Environmental Conservation, 2005a). Their decline may be linked to the increase in Raccoons and their susceptibility to Raccoon Roundworm (Baylisascaris procyonis) (New York State Department of Environmental Conservation, 2005a) or climate change (Whitaker and Hamilton, 1998). Regardless of the reason, the occurrence of Allegheny Woodrats in New York is unlikely (New York State Department of Environmental Conservation, 2005a). They are not expected to occur at SAHI.

Both the Eastern Cougar and the Gray Wolf were extirpated from New York State. A single specimen of a Gray Wolf taken from Glen Cove, Long Island, in 1951 exists at the American Museum of Natural History. The late date of this voucher is highly suspect and little information is known about the museum specimen. Although the State of New York has considered reintroduction of Gray Wolves in the Adirondack Mountain region as part of the U.S. Fish and Wildlife Service's recovery plan for the species (New York State Department of Environmental Conservation, 2005d), there are no plans to reintroduce Cougar to New York (New York State Department of Environmental Conservation, 2005c). Cou- gars are occasionally seen throughout New York, but they are probably pets that have been released to the wild (New York State Department of Environmental Conservation, 2005c). Gray Wolves and Eastern Cougars are unlikely to return to SAHI. The closely related and highly adaptable Coyote (Canis latrans) does not currently occur on Long Island, but has recently been documented in Central Park in Manhattan; it is likely that this species will one day inhabit Long Island.

Historical records show a broad distribution of Canada Lynx throughout the Northeast, including New York, prior to 1900 (Hoving and others, 2003). Lynx were considered relatively common in the Adirondacks and were recorded east of Albany, but became rare by the late 1800s (Hoving and others, 2003). Only 23 records of Canada Lynx from the 1900s are known, mostly from the Adirondacks (McKelvey and others, 1999). If Lynx occur in New York, they are likely to be found in high-elevation boreal forest, probably in the northern part of the state. Canada Lynx live in areas of deep snow through which they can pursue their preferred prey, Snowshoe Hare (Whitaker and Hamilton, 1998; Hoving and others, 2005). Lynx are not predicted to inhabit southern New York, including SAHI.

Small-footed Myotis is considered one of the rarest bats in North America and is found in mountainous regions throughout the Northeast, including New York (Best and Jennings, 1997). They hibernate in caves or mines, but little is known about their summer habits (Whitaker and Hamilton, 1998). Given the lack of information about this species, it is impossible to determine whether this species occurs at SAHI.

The New England Cottontail (Sylvilagus transitionalis) is a species of special concern in New York and the Federal government was petitioned to list the species as federally threatened or endangered; the listing status was recently updated to level two for final determination on the proposed listing (CFR 50-17; 06:53756-53835). Although the range of the New England Cottontail is believed to be much reduced from its former range (Litvaitis and others, 2003), the species does occur from the Hudson River Valley southeast to Long Island (Whitaker and Hamilton, 1998). This lagomorph is closely related to the Eastern Cottontail (S. floridanus), which is common across Long Island (Connor, 1971), and the two species can be easily confused because they are similar in appearance. Typically, New England Cottontail prefers dense thickets (Whitaker and Hamilton, 1998; U.S. Fish and Wildlife Service, 2005b). Cottontails were not detected in the park as part of this inventory, but museum specimens of both species are available for Nassau County (Connor, 1971; table 56), and it is possible that this species occurs at SAHI. Identification requires DNA analysis or examination of skull structure to distinguish the two species (Whitaker and Hamilton, 1998; U.S. Fish and Wildlife Service, 2005b); therefore, determining physical evidence such as a skeleton, biological tissue, or fecal material is required to confirm species identification (U.S. Fish and Wildlife Service, 2005b). 


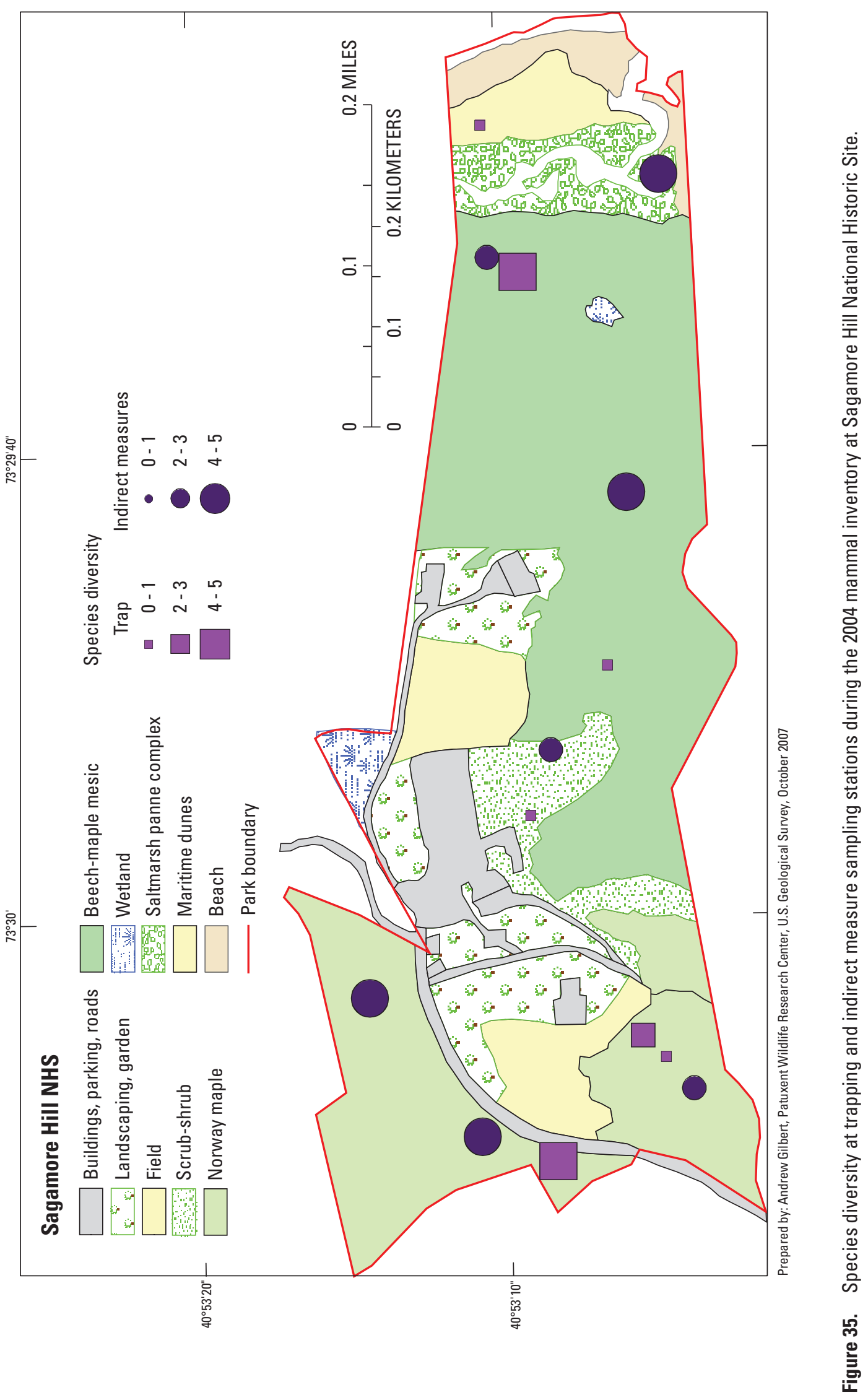


Table 56. Mammal specimens in museum collections and their proximity to Sagamore Hill National Historic Site.

[Proximity-to-park codes: 1, collected within park boundaries; 2, collected in the town (Oyster Bay, N.Y.) the park is located in; 3, collected in the county (Nassau) the park is located in. Institutions: AMNH, American Museum of Natural History; FMNH, Field Museum of Natural History. -, no specimens]

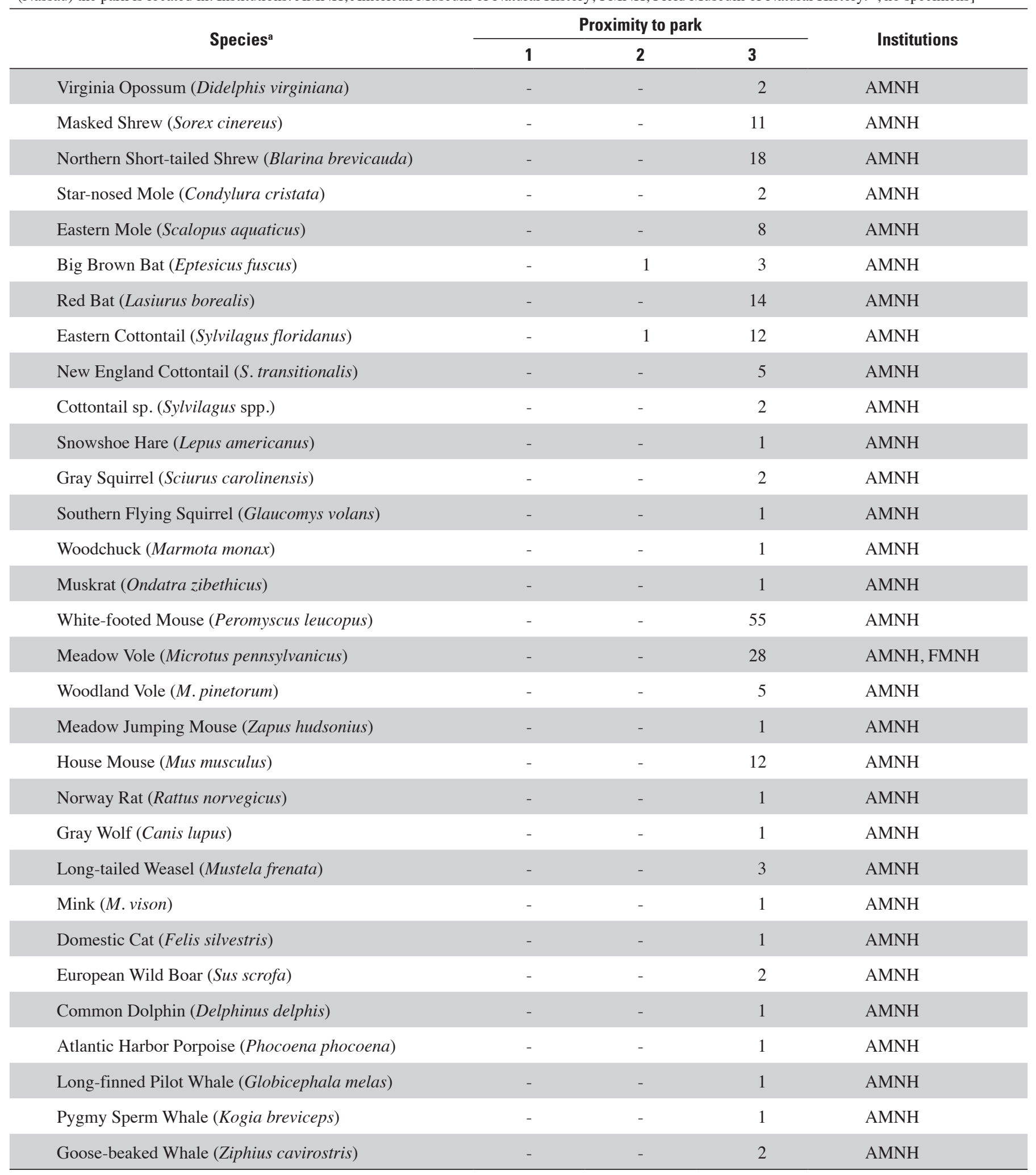

${ }^{a}$ Specimen data available through the National Park Service, NPSpecies database. For more information see: Gilbert and O'Connell, 2004; O'Connell and others, 2004; and A.F. O'Connell and A.T. Gilbert, unpublished data available at the USGS Patuxent Wildlife Research Center laboratory in Beltsville, Md.. 


\section{Suggestions for Further Study}

We endeavored in this study to conduct a complete survey of the terrestrial mammals in 10 national parks in the Northeast, using multiple survey techniques and sampling periods, but we invariably failed to detect some species. The total area necessary to sample, the relatively short period of time involved, and the resources available limited our ability to sample as often or as completely as we would have liked. Nevertheless, we believe that the sampling framework used in this study provides a good foundation for future studies in these parks to extend results for species that were not well documented. The need to sample many species with disparate behaviors and habitat usage resulted in a generalized approach to sampling that could not target all species. More comprehensive results may be gathered for a narrow group of species if future inventories focus on single or at least fewer species or utilize a single technique with more comprehensive sampling (in time and (or) space). Species-specific sampling is required among mammals with different life-history strategies (Jones, 1996) and will necessitate further study for some groups that our sampling methods did not target.

For example, we did not sufficiently sample shrews in this study. Shrews require unique methods to adequately detect or capture a representative sample. The use of pitfall traps greatly increases the effectiveness of trapping shrews (Williams and Braun, 1983; Bury and Corn, 1987; Kalko and Handley, 1993); however, pitfall traps can damage sensitive archaeological resources if placed indiscriminately. Our work on shrews was limited because we encountered difficulties in obtaining permission from NPS cultural resource managers to use pitfalls. Development of a comprehensive NPSNortheast plan that provides sampling guidelines sufficiently flexible to enable thorough inventories while ensuring that cultural resources are safeguarded would inform investigators of potential constraints early in the study planning process, reducing work delays and costs, and allow study objectives to be refined prior to implementing field work. Further inventory work on shrews is needed to more fully document these species.

Finally, additional reconnaissance is needed to determine the status of threatened or endangered species at each unit. In some cases, NPS units can serve as a temporary refuge for species like bats that migrate through these areas, or species with large home ranges (for example, carnivores) that extend beyond park boundaries. For these species, surveys must accommodate the timing of migration events or work must extend beyond park boundaries. In the latter case, the NPS could benefit from close interactions with local and state resource agencies and private landowners. The potential for threatened or endangered species to occur at each park has been discussed previously; this information can be used by resource managers as guidance for further studies of those species that may occur within respective parks and to determine whether further management action is necessary once their status is determined. Of the state and federally listed mammals reported here, Indiana Bat, Small-footed Myotis, and New England Cottontail have the greatest likelihood of occurring within park boundaries. A comprehensive survey of bats within all parks would yield valuable information. We did not inventory bats, but chose to compile information about the Indiana Bat and Small-footed Myotis to provide background information for future consideration. We did not detect New England Cottontail during this study and further targeted surveys would be necessary to understand the distribution of the New England Cottontail within the project parks.

\section{Acknowledgments}

This study was funded by the Northeast Temperate Network of the NPS Inventory and Monitoring Program. We are grateful to Elizabeth Johnson, Sara Stevens, and Greg Shriver of the NPS for making this study possible, reviewing numerous drafts of the proposal, providing direction, and dealing with the multitude of issues we encountered. Thanks to Fred Dieffenbach for helping with all matters concerning the data we collected. We also appreciate the help of Brian Mitchell for completing the editorial process and dealing with the voucher specimens. Such an effort would not be possible without the dedicated assistance of the many NPS staff and volunteers who graciously assisted with field work and logistics: Kerry Barton, Bruce Connery, Chris Davis, Scott Gurney, David Hayes, Kyle Jones, David Manski, Chris Martin, Christina Marts, Bob Mason, Theresa Moore, Daniel Noon, Steve Walasewicz, Greg Waters, and Linda White. Finally, we are grateful for administrative and technical assistance from the staffs at the USGS Patuxent Wildlife Research Center and Maine Water Science Center.

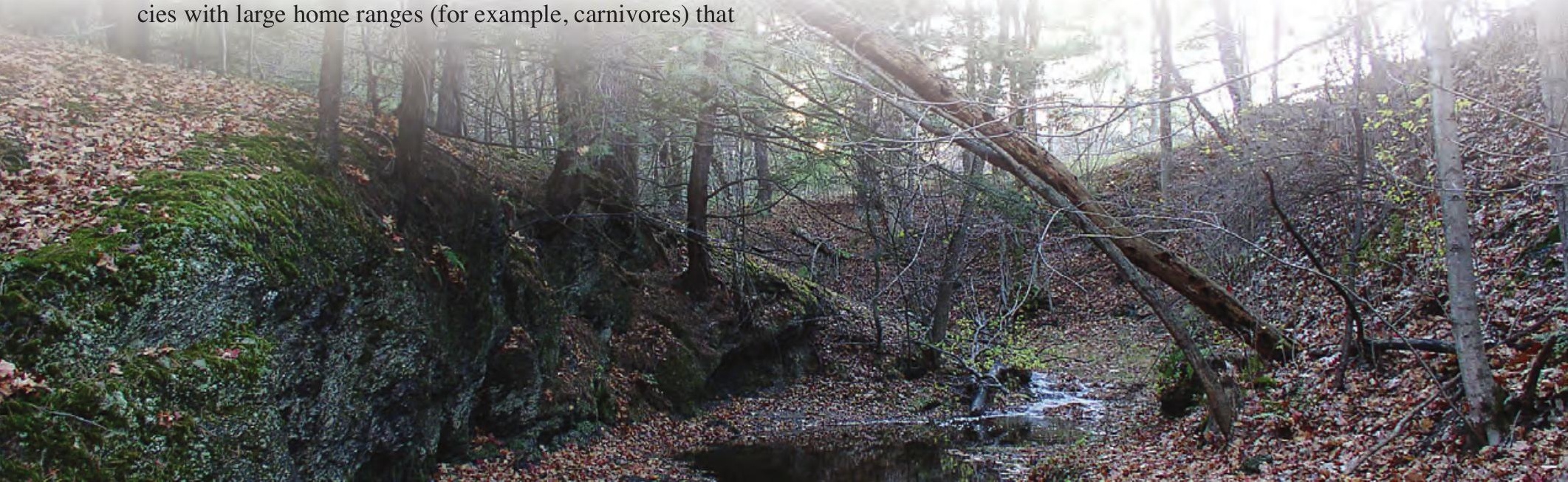




\section{References Cited}

Bailey, R.G., 1995a, 212 Laurentian mixed forest province: Fort Collins, Colo., U.S. Department of Agriculture, Forest Service. World Wide Web accessed December 13, 2005, at URL http://www.fs.fed.us/colorimagemap/images/212.html

Bailey, R.G., 1995b, M212 Adirondack-New England mixed forest-coniferous forest - alpine meadow province: Fort Collins, Colo., U.S. Department of Agriculture, Forest Service. World Wide Web accessed December 13, 2005, at URL http://www.fs.fed.us/colorimagemap/images/m212. html

Bailey, R.G., 1995c, 221 Eastern broadleaf forest (oceanic) province: Fort Collins, Colo., U.S. Department of Agriculture, Forest Service. World Wide Web accessed December 13, 2005, at URL http://www.fs.fed.us/colorimagemap/ images/221.html

Bailey, T.N., 1974, Social organization in a bobcat population: Journal of Wildlife Management, v. 38, p. 435-446.

Bailey, V., 1925, Native mammals of Mount Desert Island, unpublished report.

Balcom, B.J., and Yahner, R.H., 1995, Microhabitat and landscape characteristics associated with the threatened Allegheny Woodrat: Conservation Biology, v. 10, p. 515-525.

Belant, J.L., 2003, Comparison of 3 tracking mediums for detecting forest carnivores: Wildlife Society Bulletin, v. 31, p. 744-747.

Best, T.L., and Jennings, J.B., 1997, Mammalian speciesMyotis leibii: The American Society of Mammalogists, No. 547, p. 1-6.

Bopp, J., and Kays, R., Checklists for mammals of New York State: Albany, N.Y., New York State Museum. World Wide Web accessed March 14, 2003, at URL http://www.nysm. nysed.gov/WildSci/NY_Mammal_Checklist.html

Boulinier, T., Nichols, J.D., Sauer, J.R., Hines, J.E., and Pollock, K.H., 1998, Estimating species richness-The importance of heterogeneity in species detectability: Ecology, v. 79, p. 1018-1028.

Britzke, E.C., Hicks, A.C., Von Oettingen, S.L., and Darling, S.R., 2006, Description of spring roost trees used by female Indiana Bats (Myotis sodalis) in the Lake Champlain Valley of Vermont and New York: American Midland Naturalist, v. 155, p. 181-187.

Buckland, S.T., Magurran, A.E., Green, R.E., and Fewster, R.M., 2005, Monitoring change in biodiversity through composite indices: Philosophical Transactions of the Royal Society B, v. 360, p. 243-254.
Bury, R.B., and Corn, P.S., 1987, Evaluation of pitfall trapping in northwestern forests - trap arrays with drift fences: Journal of Wildlife Management, v. 51, p. 112-119.

Calhoun, A.J.K., Cormier, J.E., Owen, R.B., Jr., O'Connell, A.F., Jr., Roman, C.T., and Tiner, R.W., Jr., 1994, The wetlands of Acadia National Park and vicinity: Orono, Maine, University of Maine, Maine Agricultural and Forest Experiment Station, Miscellaneous Publication 721, 108 p.

Calhoun, J.B., 1959, Revised sampling procedure of the North American census of small mammals (NACSM) - Population dynamics of vertebrates: U.S Department of Health, Education, and Welfare, Mimeo Administrative Publication, Release No. 10.

Cardoza, J.E., Jones, G.S., and French, T.W., 1999, MassWildlife's state mammal list: Westborough, Mass., Massachusetts Division of Fisheries and Wildlife. World Wide Web accessed March 14, 2003, at URL http://state.mass.gov/ dfweleldfw/dfwmam.htm

Cardoza, J.E., and Langlois, S.A., 2002, The eastern cougar: a management failure?: Wildlife Society Bulletin, v. 30, p. 265-273.

Chamberlain, M.J., Leopold, B.D., and Conner, L.M., 2003, Space use, movements and habitat selection of adult Bobcats (Lynx rufus) in central Mississippi: American Midland Naturalist, v. 149 , p. 395-405.

Chenger, J., 2002, Summer survey for New Hampshire Woodland Bats: Carlisle, Pa., Bat Conservation and Management, unpublished report, $47 \mathrm{p}$.

Chilelli, M., Gilbert, J., Griffith, D.B., O'Connell, A.F., Jr., 1998, Analysis of factors affecting population viability and reintroduction of native mammals in Acadia National Park, Maine: Boston, Mass., National Park Service, Technical Report, NPS/NESO-RNR/NRTR No. 98-06, 95 p.

Christie, R.G., and Sayre, M.W., 1989, White-tailed deer management study-Morristown National Historical Park: Amherst, Mass., Department of Forestry and Wildlife Management, University of Massachusetts, Cooperative Agreement \# CA-1600-4-0005.

Coalition to Restore the Eastern Wolf, 2006, Recovery planning: Willow, N.Y., Coalition to Restore the Eastern Wolf. World Wide Web accessed December 7, 2006, at URL http://easternwolf.org/recplan.htm

Cole, S., 1993, Terrestrial mammal survey of Isle au Haut, Maine: Maine Naturalist, v. 1, p. 161-168.

Connecticut Department of Environmental Protection, 2004a, Endangered, threatened \& special concern mammals: Hartford, Ct., Connecticut Department of Environmental Protection. World Wide Web accessed April 8, 2005, at URL http://dep.state.ct.us/burnatr/wildlife/learn/esfact.htm 
Connecticut Department of Environmental Protection, 2004b, DEP continues research on cottontails: Hartford, Ct., Connecticut Department of Environmental Protection. World Wide Web accessed April 11, 2005, at URL http://www.dep. state.ct.us/whatshap/press/2004/mf092204b.htm

Connor, P.F., 1971. The mammals of Long Island, New York: Albany, N.Y., New York State Museum and Science Service, Bulletin 416, 78 p.

Cook, R., 1985, Vertebrate inventory, Saint-Gaudens National Historic Site: Boston, Mass., National Park Service, New England System Support Office, unpublished report.

Cronan, C.S., Davis, M.A., DesMeules, M.R., Litton, J.R., Nothnagle, P., and Parnell, R., 1981, Saint-Gaudens National Historic Site-A natural resource inventory: Christopher S. Cronan and Associates, unpublished report, $136 \mathrm{p}$.

Crooks, K.R., 2002, Relative sensitivities of mammalian carnivores to habitat fragmentation: Conservation Biology, v. 16, p. 488-502.

Cunningham, J., Calhoun, A.J.K., and Glanz, W.E., 2006, Patterns of beaver colonization and wetland change in Acadia National Park: Northeastern Naturalist, v. 13, p. 583-596.

Degraff, R.M., and Rudis, D.D., 1986, New England wildlife - habitat, natural history, and distribution: Broomall, Pa., U.S Department of Agriculture, Forest Service, Northeastern Forest Experiment Station, General Technical Report NE-108, 491 p.

Elbroch, M., 2003, Mammal tracks \& sign - A guide to North American species: Mechanicsburg, Pa., Stackpole Books., $795 \mathrm{p}$.

Faccio, S.D., 2001, A biological inventory of amphibians and reptiles at the Marsh-Billings-Rockefeller National Historical Park and adjacent lands: Woodstock, V.T., National Park Service, Technical Report NPS/NER/NRTR-2005/008, $34 \mathrm{p}$.

Fancy, S.G., 2000, Guidance for the design of sampling schemes for inventory and monitoring of biological resources in national parks: Fort Collins, Colo., National Park Service, Inventory and Monitoring Program, unpublished report, $10 \mathrm{p}$.

Favour, P.G., 1940, The 1940 fall deer census of Mount Desert, Maine, including Acadia National Park, unpublished report.

Fedriani, J.M., Fuller, T.K., Sauvajot, R.M., and York, E.C., 2000, Competition and intraguild predation among three sympatric carnivores: Oecologia, v. 125, p. 258-270.

Field, S.A., O'Connor, P.J., Tyre, A.J., and Possingham, H.P., 2007, Making monitoring meaningful: Austral Ecology, v. 32 , p. 485-491.
Folger, D.C., and Wayne, P.M., 1986, A biological inventory of Great Duck Island, Hancock County, Maine: Bar Harbor, Maine, College of the Atlantic, unpublished report.

Forman, R.T.T., and Deblinger, R.D., 2000, The ecological road-effect zone of a Massachusetts (U.S.A.) suburban highway: Conservation Biology, v. 14, p. 34-46.

Foster, D.R., 1992, Land use history (1730-1990) and vegetation dynamics in central New England, USA: The Journal of Ecology, v. 80, p. 753-771.

Garman, S.L., 1991, Habitat associations of small mammals in seral stages of red spruce in Acadia National Park, Maine: Amherst, Mass., University of Massachusetts, Ph.D. dissertation, $291 \mathrm{p}$.

Garman, S.L., O'Connell, A.F., Jr., and Connery, J.H., 1994, Habitat use and distribution of the mice Peromyscus leucopus and P. maniculatus on Mount Desert Island Maine: The Canadian Field-Naturalist, v. 108, p. 67-71.

Geissler, P.H., and McDonald, T.L., 2003, A comparison of grid sampling designs with stratified/nonuniform probability sampling designs for national park monitoring, The George Wright Society/National Park Service Joint Conference, April 14-18, 2003, San Diego, Calif., unpublished report.

Gilbert, A.T., and O'Connell, A.F., 2004, Retrieval, compilation, and organization of vertebrate and vascular plant voucher specimens originating from national parks, in Harmon, D., Kilgore, B.M., and Vietzke, G.E., eds., 2004, Protecting our diverse heritage-The role of parks, protected areas, and cultural sites, Proceedings of the George Wright Society/National Park Service Joint Conference, April 14-18, 2003, San Diego, California: Hancock, Mich., The George Wright Society, p. 400-405.

Gillis, E.A., and Krebs, C.J., 1999, Natal dispersal of Snowshoe Hares during a cyclic population increase: Journal of Mammalogy, v. 80, p. 933-939.

Glanz, W.E., and Connery, B., 1999, Biological inventories of Schoodic and Corea Peninsulas, coastal Maine, 1996: Boston, Mass., National Park Service Technical Report NPS/ BSO-RNR/NRTR/00-4, 150 p.

Godin, A.J., 1977, Wild mammals of New England: Baltimore, Md., The Johns Hopkins University Press, 123 p.

Goebel, J.J., and Baker, H.D., 1982, The 1982 National Resources Inventory sample design and estimation procedures: Ames, Iowa, Iowa State University Statistical Laboratory.

Goodwin, G.G., 1936, Big game animals in the northeastern United States: Journal of Mammalogy, v. 17, p. 48-50. 
Halfpenny, J., and Biesiot, E., 1986, A field guide to mammal tracking in North America: Boulder, Colo., Johnson Books, $176 \mathrm{p}$.

Harrison, D.J., 1989, A proposal to inventory carnivores on Mount Desert Island, Maine: Boston, Mass, Proposal submitted to the National Park Service.

Harrison, D.J., and Chapin, T.G., 1997, An assessment of potential habitat for Eastern Timber Wolves in the northeastern United States and connectivity with occupied habitat in southeastern Canada: Bronx, N.Y., Wildlife Conservation Society, Working Papers 7,13 p.

Hazen, J., O’Connell, A., La Combe, E., Rand, P., and Smith, R., 1992, Visitor risk assessment and Lyme disease ecology in Acadia National Park, in Willison, J.H.M, ed., 1992, Developments in landscape management and urban planning, \#7: Amsterdam, Netherlands, Elsevier Publishing Co., p. 523-526.

Hollemeyer, K., Altmeyer, W., and Heinzle, E., 2002, Identification and quantification of feathers, down, and hair of avian and mammalian origin using matrix-assisted laser desorption/ionization time-of-flight mass spectrometry: Analytical Chemistry, v. 74, p. 5960-5968.

Holloway, G.L., and Malcolm, J.R., 2007, Northern and southern flying squirrel use of space within home ranges in central Ontario: Forest Ecology and Management, v. 242, p. 747-755.

Hoving, C.L., Harrison, D.J., Krohn, W.B., Joseph, R.A., and O'Brien, M., 2005, Broad-scale predictors of Canada Lynx occurrence in eastern North America: Journal of Wildlife Management, v. 69, p. 739-751.

Hoving, C.L., Joseph, R.A., and Krohn, W.B., 2003, Recent and historical distribution of Canada Lynx in Maine and the northeast: Northeastern Naturalist, v. 10, p. 363-382.

Hudson River Trustee Council, 2002, Hudson River natural resource damage assessment plan: Albany, N.Y., Hudson River Trustee Council. World Wide Web accessed September 21, 2007, at URL http://www.fws.gov/contaminants/ restorationplans/HudsonRiver/HudsonRiverNRDASept 2002. $p d f$

Johnson, E., Stevens, S.M., Paton, P., Faccio, S.D., O’Connell, A., Longcore, J.R., McAuley, D. G., Sauer, J.R., and Moring, J.R., 2000, Northeast Temperate Network inventory study plan for vertebrate and vascular plant species, National Park Service, Inventory and Monitoring Program, unpublished report.
Jones, C., McShea, W.J., Conroy, M.J., and Kunz, T.H., 1996, Capturing mammals, in Wilson, D.E., Cole, F.R., Nichols, J.D., Rudran, R., and Foster, M.S., eds., 1996, Measuring and monitoring biological diversity — standard methods for mammals: Washington, D.C., Smithsonian Institution, p. 115-155.

Kalko, E.K.V., and Handley, C.O., 1993, Comparative studies of small mammal populations with transects of snap traps and pitfall arrays in southwest Virginia: Virginia Journal of Science, v. 44, p. 3-18.

Kamler, J.F., Pennock, D.S., Welch, C., and Pierotti, R.J., 1998, Variation in morphological characteristics of the White-footed Mouse (Peromyscus leucopus) and the Deer Mouse (P. maniculatus) under allotopic and syntopic conditions: American Midland Naturalist, v. 140, p. 170-179.

Kart, J., Regan, R., Darling, S.R., Alexander, C., Cox, K., Ferguson, M., Parren, S., Royar, K., Popp, B., eds., 2005, Vermont's Wildlife Action Plan: Waterbury, Vt., Vermont Fish and Wildlife Department. World Wide Web accessed February 11, 2008, at URL http://www.vtfishandwildlife. com/CWCS_Report/VT_Willdife_Action_Plan_Main_ Document.pdf

Kelly, J.R., 2005, Species profile-American Marten Martes americana, in New Hampshire Fish and Game Department, 2005, New Hampshire Wildlife Action Plan: Concord, N.H., New Hampshire Fish and Game Department, p. A253-A260. World Wide Web accessed February 11, 2008, at URL http://www.wildlife.state.nh.us/Wildlife/ Wildlife_Plan/WAP_pieces/WAP_App_A_Mammals.pdf

Kilpatrick, H., 2005, Research on New England Cottontail rabbits continues: Connecticut Wildlife, v. 25, p. 9.

Krohn, W.B., Zielinski, W.J., and Boone, R.B., 1997, Relations among Fishers, snow, and Martens in California: results from small-scale spatial comparisons, in Proulx, G., Bryant, H.N., and Woodard, P.M., eds., 1997, Martes - taxonomy, ecology, techniques, and management: Edmonton, Alberta, Canada, Provincial Museum of Alberta, p. 211-232.

Kurta, A., King, D., Teramino, J.A., Stribley, J.M., and Williams, K.J., 1993, Summer roosts of the endangered Indiana Bat (Myotis sodalis) on the northern edge of its range: American Midland Naturalist, v. 129, p. 132-138.

Lautzenheiser, T., 2002, Marsh-Billings-Rockefeller National Historical Park Woodstock, Vermont natural community report: Burlington, Vt., University of Vermont, unpublished report, $39 \mathrm{p}$.

Linzey, A.V., 1983, Mammalian Species-Synaptomys cooperi: The American Society of Mammalogists, No. 210, p. $1-5$. 
Litvaitis, J.A., 1993, Response of early successional vertebrates to historic changes in land use: Conservation Biology, v. 7, p. 866-873.

Litvaitis, J.A., Johnson, B., Jakubas, W., and Morris, K., 2003, Distribution and habitat features associated with remnant populations of New England Cottontails in Maine: Canadian Journal of Zoology, v. 81, p. 877-887.

LoBue, J., and Darnell, R.M., 1959, Effect of habitat disturbance on a small mammal population: Journal of Mammalogy, v. 40, p. 425-436.

Long, R.A., O'Connell, A.F., Jr., and Harrison, D.J., 1998, Mortality and survival of White-tailed Deer Odocoileus virginianus fawns on a north Atlantic coastal island: Wildlife Biology, v. 4, p. 237-247.

Loukmas, J.J., Mayack, D.T., and Richmond, M.E., 2001, Evaluation of track plate enclosure design for recording the presence of mink: Ithaca, N.Y., Cooperative Fish and Wildlife Research Unit, unpublished report, $11 \mathrm{p}$.

Loukmas, J.J., Mayack, D.T., and Richmond, M.E., 2002, Track plate enclosures: box designs affecting attractiveness to riparian mammals: American Midland Naturalist, v. 149, p. 219-224.

MacKenzie, D.I., Nichols, J.D., Hines, J.E., Knutson, M.G., and Franklin, A.B., 2003, Estimating site occupancy, colonization, and extinction when a species is detected imperfectly: Ecology, v. 84, p. 2200-2207.

MacKenzie, D.I., Nichols, J.D., Lachman, G.B., Droege, S., Royle, R.A., and Langtimm, C.A., 2002, Estimating site occupancy rates when detection probabilities are less than one: Ecology, v. 83, p. 2248-2255.

MacKenzie, D.I., Nichols, J.D., Royle, J.A., Pollock, K.H., Bailey, L.L., and Hines, J.E., 2006, Occupancy estimation and modeling - Inferring patterns and dynamics of species occurrence: New York, N.Y., Academic Press, 344 p.

MacKenzie, D.I., and Royle, J.A., 2005, Designing occupancy studies-General advice and allocating survey effort: Journal of Applied Ecology, v. 42, p. 1105-1114.

Maine Department of Inland Fisheries and Wildlife, 2003, Federally endangered-Eastern Cougar (Felis concolor couguar): Augusta, Maine, Maine Department of Inland Fisheries and Wildlife. World Wide Web accessed February 7, 2008, at URL http://maine.gov/ifw/wildlife/species/ endangered_species/eastern_cougar/eastern_cougar.pdf
Maine Department of Inland Fisheries and Wildlife, 2006, Maine Endangered and Threatened Species Program, endangered and threatened species, mammals that are endangered or threatened in Maine: Augusta, Maine, Maine Department of Inland Fisheries and Wildlife. World Wide Web accessed May 26, 2006, at URL http://www.maine.gov/ifw/wildlife/ etweb/mammal_list.htm

Manville, R.H., 1942, Notes on the mammals of Mt. Desert Island, Maine: Journal of Mammalogy, v. 23, p. 391-398.

Manville, R.H., 1960, The vertebrate fauna of Isle au Haut, Maine: American Midland Naturalist, v. 72, p. 396-407.

Manville, R.H., 1964, Recent changes in the mammal fauna of Mount Desert Island, Maine: Journal of Mammalogy, v. 41, p. 415-416.

Massachusetts Department of Fisheries and Wildlife, 2003, Massachusetts list of endangered, threatened and special concern species: Westborough, Mass., Massachusetts Department of Fisheries and Wildlife. World Wide Web accessed March 13, 2003, at URL http://www.state.ma.us/ dfwele/dfw/nhesp/nhrare.htm

Mayer, W.V., 1952, The hair of California mammals with keys to the dorsal guard hairs of California mammals: American Midland Naturalist, v. 48, p. 480-512.

McKelvey, K.S., Aubry, K.B., and Ortega, Y.K., 1999, History and distribution of Lynx in the contiguous United States, in Ruggerio, L.F., Aubry, K.B., Buskirk, S.W., Koehler, G.M., Krebs, C.J., McKelvey, K.S., and Squires, J.R., eds., 1999, Ecology and conservation of Lynx in the United States: Fort Collins, Colo., U.S. Department of Agriculture, Forest Service, General Technical Report RMRS-GTR-30WWW, p. 207-264.

McMahon, J.S., 1990, The biophysical regions of MainePatterns in the landscape and vegetation: Orono, Maine, University of Maine, M.S. Thesis, 120 p.

Mech, L.D., 1996, A new era for carnivore conservation: Wildlife Society Bulletin, v. 24, p. 397-401.

Mills, J.N., Johnson, J.M., Ksiazek, T.G., Ellis, B.A., Rollin, P.E., Yates, T.L., Mann, M.O., Johnson, M.R., Campbell, M.L., Miyashiro, J., Patrick, M., Zyzak, M., Lavender, D., Novak, M.G., Schmidt, K., Peters, C.J., and Childs, J.E., 1998, A survey of hantavirus antibody in small-mammal populations in selected United States national parks: American Journal of Tropical Medicine and Hygiene, v. 58, p. 525-532. 
Mitchell, B.R., Shriver, W.G., Dieffenbach, F., Moore, T., Faber-Langendoen, D., Tierney, G., Lombard, P., and Gibbs, J., 2006, Northeast Temperate Network vital signs monitoring plan: Woodstock, Vt., National Park Service, Northeast Temperate Network, Technical Report NPS/NER/NRTR 2006/059, 152 p.

Mittelhauser, G., Connery, B., Breen, A., and McGrath, T., 1995, Biological inventory of Acadia National Park and U.S. Navy lands on the Schoodic Peninsula, Maine: Bar Harbor, Maine, National Park Service, Acadia National Park, unpublished report, $93 \mathrm{p}$.

Mittelhauser, G., Connery, J.H., and Jacobs, J., 1996, Inventories of selected flora and fauna on 10 islands of Acadia National Park, Maine: Boston, Mass., National Park Service Technical Report NPS/NESO-RNR/NRTR/96-01, 126 p.

Moore, D.W., and Braun, J.K., 1983, Keys to the hairs of the families Soricidae, Vespertilionidae, and Muridae within Tennessee: Journal of the Tennessee Academy of Science, v. 58, p. $40-43$.

Moore, T.D., Spence, L.E., Dugnolle, C.E., and Hepworth, W.G., 1974, Identification of the dorsal guard hairs of some mammals of Wyoming: Cheyenne, Wyo., Wyoming Game and Fish Department, 175 p.

Moruzzi, T.L., Royar, K.J., Grove, C., Brooks, R.T., Bernier, C., Thompson, F.L., Jr., DeGraaf, R.M., and Fuller, T.K., 2003, Assessing an American Marten, Martes americana, reintroduction in Vermont: The Canadian Field-Naturalist, v. 117, p. 190-195.

Mowat, G., and Paetkau, D., 2002, Estimating marten Martes americana population size using hair capture and genetic tagging: Wildlife Biology, v. 8, p. 201-209.

Murie, O.J., 1974, A field guide to animal tracks: New York, N.Y., Houghton Mifflin Co., 375 p.

National Climatic Data Center, 2005, Monthly and seasonal total snowfall amount-Lebanon FAA Airport: Asheville, N.C., National Climatic Data Center. World Wide Web accessed December 23, 2005, at URL http:// www.ncdc.noaa.gov/ussc/SCopTab1? state $=$ New $\% 20$ Hampshire \& station $=$ LEBANON\%20FAA\%20 AIRPORT\&coopid $=274656 \&$ short $=27$

National Climatic Data Center, 2006a, Monthly surface data for Poughkeepsie, New York: Asheville, N.C., National Climatic Data Center. World Wide Web accessed April 14, 2006, at URL http://cdo.ncdc.noaa.gov/pls/plclimprod/ poemain. dobystn? dataset $=D S 3220 \&$ StnList $=N N N N N$ N14757,30682014757
National Climatic Data Center, 2006b, Monthly surface data for Woodstock, Vermont: Asheville, N.C., National Climatic Data Center. World Wide Web accessed March 24, 2006, at URL http://cdo.ncdc.noaa.gov/pls/plclimprod/poemain.cdob ystn? dataset $=$ DS3220\&StnList $=439984 N N N N N$

National Park Service, 1999a, Guidelines for biological inventories (revised September 8, 1999): Fort Collins, Colo., National Park Service. World Wide Web accessed December 11, 2006, at URL http://www.nature.nps.gov/biology/ biologicalinventories/bioinv.cfm\#GuidelinesForBiologicalI nentories

National Park Service, 1999b, Natural resource challenge: The National Park Service's action plan for preserving natural resources: Fort Collins, Colo., National Park Service, Natural Resource Information Division. World Wide Web accessed August 13, 2007, at URL http://www.nature.nps. gov/challenge/challengedoc/NatRes2.pdf

National Park Service, 2002, National Park Service database specifications for inventory and monitoring studies: Fort Collins, Colo., National Park Service, Inventory and Monitoring Program, unpublished report, $16 \mathrm{p}$.

National Park Service, 2006, Acadia National Park-Weather: Bar Harbor, Maine, National Park Service. World Wide Web accessed February 27, 2007, at URL http://www.nps.gov/ acad/planyourvisit/weather.htm

The Nature Conservancy, 2005, Weir Nature Preserve: Arlington, Va., The Nature Conservancy. World Wide Web accessed March 25, 2005, at URL http://nature.org/ wherewework/northamerica/states/connecticut/preserves/ art5764.htm

New Hampshire Fish and Game Department, 2005, Endangered and Threatened Wildlife of New Hampshire: Concord, N.H., New Hampshire Fish and Game Department. World Wide Web accessed December 22, 2005, at URL http://www.wildlife.state.nh.us/Wildlife/Nongame/ endangered_list.htm

New Jersey Audubon Society, 2003a, A checklist of mammals, reptiles and amphibians: Bernardsville, N.J., New Jersey Audubon Society. World Wide Web accessed March 26, 2003, at URL http://www.njaudubon.org/NatureNotes/njlist. html

New Jersey Audubon Society, 2003b, Scherman-Hoffman Wildlife Sanctuary mammal checklist: Bernardsville, N.J., New Jersey Audubon Society, Scherman-Hoffman Wildlife Sanctuary.

New Jersey Division of Fish and Wildlife, 2005a, Allegheny Woodrat, Neotoma magister: Trenton, N.J., New Jersey Division of Fish and Wildlife. World Wide Web accessed April 19, 2005, at URL http://www.state.nj.us/dep/fgw/ensp/ pdf/end-thrtened/woodrat.pdf 
New Jersey Division of Fish and Wildlife, 2005b, Bear facts for New Jersey: Trenton, N.J., New Jersey Division of Fish and Wildlife. World Wide Web accessed December 6, 2005, at URL http://www.state.nj.us/dep/fgw/bearinfo.htm

New Jersey Division of Fish and Wildlife, 2005c, Bobcat, Felis rufus: Trenton, N.J., New Jersey Division of Fish and Wildlife. World Wide Web accessed April 19, 2005, at URL http://www.state.nj.us/dep/fgw/ensp/pdf/end-thrtened/ bobcat.pdf

New Jersey Division of Fish and Wildlife, 2005d, Indiana Bat, Myotis sodalis: Trenton, N.J., New Jersey Division of Fish and Wildlife. World Wide Web accessed April 19, 2005, at URL http://www.state.nj.us/dep/fgw/ensp/pdf/end-thrtened/ indianabat.pdf

New Jersey Division of Fish and Wildlife, 2005e, New Jersey's mammals: Trenton, N.J., New Jersey Division of Fish and Wildlife. World Wide Web accessed April 19, 2005, at URL http://www.state.nj.us/dep/fgw/ensp/mammal_info.htm

New York State Department of Environmental Conservation, 2005a, Allegheny Woodrat fact sheet: Albany, N.Y., New York State Department of Environmental Conservation. World Wide Web accessed December 6, 2005, at URL http://www.dec.state.ny.us/website/dfwmr/wildlife/endspec/ alwofs.html

New York State Department of Environmental Conservation, 2006b, Black Bear: Albany, N.Y., New York State Department of Environmental Conservation. World Wide Web accessed December 6, 2006, at URL http://www.dec.state. ny.us/website/dfwmr/wildlife/wildgame/bear.htm

New York State Department of Environmental Conservation, 2005c, Eastern Cougar fact sheet: Albany, N.Y., New York State Department of Environmental Conservation. World Wide Web accessed December 6, 2005, at URL http://www. dec.state.ny.us/website/dfwmr/wildlife/endspec/eacofs.html

New York State Department of Environmental Conservation, 2005d, Gray Wolf fact sheet: Albany, N.Y., New York State Department of Environmental Conservation. World Wide Web accessed December 6, 2005, at URL http://www.dec. state.ny.us/website/dfwmr/wildlifelendspec/grwofs.html

New York State Department of Environmental Conservation, 2005e, Indiana Bat fact sheet: Albany, N.Y., New York State Department of Environmental Conservation. World Wide Web accessed December 6, 2005, at URL http://www.dec. state.ny.us/websiteldfwmr/wildlifelendspec/inbafs.html
New York State Department of Environmental Conservation, 2005f, List of endangered, threatened and special concern fish \& wildlife species of New York State: Albany, N.Y., New York State Department of Environmental Conservation. World Wide Web accessed December 6, 2005, at URL http://www.dec.state.ny.us/website/dfwmr/wildlife/endspec/ etsclist.html

New York State Department of Environmental Conservation, 2006g, Historic Black Bear harvest data: Albany, N.Y., New York State Department of Environmental Conservation. World Wide Web accessed December 6, 2006, at URL http://www.dec.state.ny.us/website/dfwmr/wildlife/ wildgame/beartake.htm

Nichols, J.D., Bailey, L.L., O’Connell, A.F., Jr., Talancy, N.W., and others, 2008, Multi-scale occupancy estimation and modelling using multiple detection methods: Journal of Applied Ecology, v. 45, no. 5, p. 1321-1329.

Nichols, J.D., Boulinier, T., Hines, J.E., Pollock, K.H., and Sauer, J.R., 1998, Estimating rates of local species extinction, colonization and turnover in animal communities: Ecological Applications, v. 8, p. 1213-1225.

Nichols, J.D., and Williams, B.K., 2006, Monitoring for conservation: Trends in Ecology and Evolution, v 21, p. 668-673.

Nielson, C.K., and Woolf, A., 2001, Spatial organization of Bobcats (Lynx rufus) in southern Illinois: American Midland Naturalist, v. 146, p. 43-52.

O’Connell, A.F., Gilbert, A.T., and Hatfield, J.S., 2004, Contribution of natural history collection data to biodiversity assessment in national parks: Conservation Biology, v. 18, p. 1254-1261.

O'Connell, A.F., Jr., Harrison, D.J., Connery, B., and Anderson, K.B., 1992, Food use by an insular population of coyotes: Northeast Wildlife, v. 49, p. 36-42.

O'Connell, A.F., Jr., Servello, F.A., Higgins, J., and Halteman, W., 2001, Status and habitat relationships of northern flying squirrels on Mount Desert Island, Maine: Northeastern Naturalist, v. 8, p. 127-136.

O’Connell, A.F., Jr., Talancy, N.W., Bailey, L.L., Sauer, J.R., Cook, R., and Gilbert, A.T., 2006, Estimating site occupancy and detection probability parameters for meso- and large mammals in a coastal ecosystem: Journal of Wildlife Management, v. 70, p. 1625-1633.

Ostfeld, R.S., and Canham, C.D., 1995, Density dependent processes in Meadow Voles - an experimental approach: Ecology, v. 76, p. 521-532. 
Packie, R., and Nadeau, J., 1975, A report on the occurrence of small mammals in six habitat types on Mount Desert Island: Bar Harbor, Maine, National Park Service, Acadia National Park, unpublished report, $7 \mathrm{p}$.

Patterson, W.A., III, Saunders, K.E., and Horton, L.J., 1983, Fire regimes of the coastal Maine forests of Acadia National Park: Boston, Mass., National Park Service, Technical Report OSS-83-3, 259 p.

Pipliski, L.M., 2002, Abundance, distribution, and species diversity of bats at Morristown National Historical Park: Wayne, N.J., William Patterson University, unpublished report, $11 \mathrm{p}$.

Pollock, K.H., Nichols, J.D., Simon, T.R., Farnsworth, G.L., Bailey, L.L., and Sauer, J.R., 2002, Large scale wildlife monitoring studies - Statistical methods for design and analysis: Envirometrics, v. 13, p. 105-119.

Porter, W.F., and Underwood, H.B., 1997, Feasibility of a fertility control program for White-tailed Deer at Morristown National Historical Park-Phase II (a work plan): Syracuse, N.Y., State University of New York, College of Environmental Science and Forestry, unpublished report.

Powell, R.A, 1981, Mammalian Species-Martes pennanti: American Society of Mammalogists, No. 156, p. 1-6.

Reynolds, D.S., and McFarland, K.P., 2001, Bat biodiversity survey, Marsh-Billings-Rockefeller National Historic Park: Concord, N.H., North East Ecological Services, unpublished report, $17 \mathrm{p}$.

Rezendes, P., 1995, Tracking and the art of seeing-How to read animal tracks and sign (1st ed.): Charlotte, Vt., Camden House Publishing, 320 p.

Risch, T., and Brady, M.J., 1996, Trap height and capture success of arboreal small mammals: Evidence from southern flying squirrels (Glaucomys volans): American Midland Naturalist, v. 136, p. 346-351.

Rosatte, R., and Larivière, S., 2003, Skunks (Genera Mephitis, Spilogale, and Conepatus), in Feldhammer, G.A., Thompson, B.C., and Chapman, J.A., eds., 2003, Wild mammals of North America-Biology, management, and conservation (2d ed.): Baltimore, Md., John Hopkins University Press, p. 692-707.

Rosenblatt, D.L., Heske, E.J., Nelson, S.L., Barber, D.M., Miller, M.A., and MacAllister, B., 1999, Forest fragments in east-central Illinois - Islands or habitat patches for mammals?: American Midland Naturalist, v. 141, p. 115-123.

Royle, J.A., and Nichols J.D., 2003, Estimating abundance from repeated presence-absence data or point counts: Ecology, v. 84, p. 777-790.
Ruhren, S., and Handel, S.N., 2003, Herbivory constrains survival, reproduction and mutualisms when restoring nine temperate forest herbs: Journal of the Torrey Botanical Society, v. 130, p. 34-42.

Saeki, M., 1991, Influence of browsing by white-tailed deer and snowshoe hare on vegetation at Acadia National Park, Maine: Orono, Maine, University of Maine, M.S. thesis, $120 \mathrm{p}$.

Smith, B.E., Marks, P.L., and Gardescu, S., 1993, Two hundred years of forest cover changes in Tompkins County, New York: Bulletin of the Torrey Botanical Club, v. 120, p. 229-247.

State University of New York, Albany, 2006, Albany, N.Y. climate summary: Albany, N.Y., State University of New York. World Wide Web accessed April 14, 2006, at URL http:// www.atmos.albany.edu/deas/albclim.html

Steadman, D.W., 1991, Field survey of small mammalsRoosevelt-Vanderbilt National Historic Sites, Hyde Park, New York: Albany, N.Y., New York State Museum, unpublished report, $14 \mathrm{p}$.

Steblein, P.F., and Mathews, N.E., 1987, Range and distribution of Lyme disease hosts and vectors in the Hudson Valley and peripheral Adirondacks: Syracuse, N.Y., State University of New York, College of Environmental Science and Forestry, unpublished report.

Stupka, A., 1932-35, Various articles in Nature notes from Acadia: Bar Harbor, Maine, National Park Service, Acadia National Park library archives, v. 1-4.

Svendsen, G.E., 2003, Weasels and Black-footed Ferret, in Feldhammer, G.A., Thompson, B.C., and Chapman, J.A., eds., 2003, Wild mammals of North America-Biology, management, and conservation ( $2 \mathrm{~d}$ ed.): Baltimore, Md., John Hopkins University Press, p. 650-671.

Talancy, N.W., 2005, Effects of habitat fragmentation and landscape context on medium-sized mammalian predators in northeastern national parks: Kingston, R.I., University of Rhode Island, M.S. thesis, 134 p.

Taulman, J.F., and Smith, K.G., 2004, Home range and habitat selection of southern flying squirrels in fragmented forests: Mammalian Biology, v. 69, p.11-27.

Taylor, C.A., and Raphael, M.G., 1988, Identification of mammal tracks from sooted track stations in the Pacific Northwest: California Fish and Game, v. 74, p. 4-15.

Thompson, I.D., Porter, M.S., and Walker, S.L., 1987, A key to identification of some small boreal mammals of central Canada from guard hairs: The Canadian Field-Naturalist, v. 101, p. 614-616. 
Thomson, C.E., 1982, Mammalian Species - Myotis sodalis: The American Society of Mammalogists, No. 163, p. 1-5.

Thornton, D.H., Sunquist, M.E., and Main, M.B., 2004, Ecological separation within newly sympatric populations of Coyotes and Bobcats in south-central Florida: Journal of Mammalogy, v. 85, p. 973-982.

Trombulak, S.C., Higuera, P.E., and DesMeules, M., 2001, Population trends of wintering bats in Vermont: Northeastern Naturalist, v. 8, p. 51-62.

Underwood, H.B., 1997, Feasibility of a fertility control program for White-tailed Deer at Morristown National Historical Park-Phase I: Syracuse, N.Y., State University of New York, College of Environmental Science and Forestry, unpublished report, $9 \mathrm{p}$.

Underwood, H.B., Austin, K.A., Porter, W.F., Burgess, R.L., and Sage, R.W., Jr., 1994, Interactions of white-tailed deer and vegetation at Saratoga National Historical Park: Stillwater, N.Y., National Park Service, Technical Report NPS/ NAROSS/NRTR/95-28, $32 \mathrm{p}$.

University of New Hampshire Cooperative Extension, 1998, Rare Wildlife of New Hampshire: Small-footed Bat (Myotis leibii): Manchester, N.H., University of New Hampshire Cooperative Extension. World Wide Web accessed December 22, 2005, at URL http://ceinfo.unh.edu/Wildlife/Pubs/ res_bat.pdf

U.S. Fish and Wildlife Service, 2005a, Great Meadows National Wildlife Refuge: Sudbury, Mass., U.S. Fish and Wildlife Service. World Wide Web accessed December 16, 2005, at URL http://www.fws.gov/northeast/greatmeadows/

U.S. Fish and Wildlife Service, 2005b, New England Cottontail Fact Sheet: Hadley, Mass., U.S. Fish and Wildlife Service, Northeast Region, 2p.

Veilleux, J.P., and Reynolds S., 2005, Eastern Small-footed Bat Myotis leibii, in New Hampshire Fish and Game Department, 2005, New Hampshire Wildlife Action Plan: Concord, N.H., New Hampshire Fish and Game Department, p. A328-A333. World Wide Web accessed February 11, 2008, at URL http://www.wildlife .state.nh.us/Wildlife/ Wildlife_Plan/WAP_pieces/WAP_App_A_Mammals.pdf

Vermont Fish and Wildlife Department, 2005, Endangered and threatened animals of Vermont: Waterbury, Vt., Vermont Fish and Wildlife Department. World Wide Web accessed March 24, 2006, at URL http://www.vtfishandwildlife.com/ library/Reports_and_documents/nongame_and_Natural_ Heritage/Rare_Threatened_and_Endangered_Species/ Endangered_and_Threatened_Animals_of_VermontApril_2005.pdf
Wallis, R.L., 1993, A key for the identification of guard hairs of some Ontario mammals: Canadian Journal of Zoology, v. 71, p. 587-591.

Waters, J.H., and Ray, C.E., 1961, Former range of the Sea Mink: Journal of Mammalogy, v. 42, p. 380-383.

Way, J.G., Ortega, I.M., and Strauss, E.G., 2004, Movement and activity patterns of Eastern Coyote in a coastal, suburban environment: Northeastern Naturalist, v. 11, p. $237-254$.

Weigl, P.D., 1978, Resource overlap, interspecific interactions, and the distribution of the flying squirrels Glaucomys volans and G. sabrinus: American Midland Naturalist, v. 100, p. 83-96.

Whitaker, J.O., and Hamilton, J., Jr., 1998, Mammals of the Eastern United States ( $3 \mathrm{~d}$ ed.): Ithaca, N.Y., Comstock Publishing, 583 p.

Wildlife Trails Education Project, 2002, Assabet River NWR: Concord, Mass., Wildlife Trails Education Project. World Wide Web accessed December 5, 2006, at URL http://www. wtep.org/default.htm

Williams, D.F., and Braun, S.E., 1983, Comparison of pitfall and conventional traps for sampling small mammal populations: Journal of Wildlife Management, v. 47, p. 841-845.

Williamson, V.H.H., 1951, Determination of hairs by impressions: Journal of Mammalogy, v. 32, p. 80-84.

Winter, L.A., 1990, Home range size and spatial relationships of coyotes and red foxes in Acadia National Park, Mount Desert Island, Maine: Orono, Maine, University of Maine, M.S. thesis, $74 \mathrm{p}$.

Yoccoz, N.G., Nichols, J.D., and Boulinier, T., 2001, Monitoring of biological diversity in space and time: Trends in Ecology \& Evolution, v. 16, p. 446-453.

Zielinski, W.J., 1995, Trackplates, in Zielinski, W.J., and Kucera, T.E., eds., 1995, American Marten, Fisher, Lynx, and Wolverine-Survey methods for their detection: U.S. Department of Agriculture, Forest Service, General Technical Report PSW GTR-157, 163 p.

Zimmerman, G., 1998, Inventory and habitat use of bats along the central coast of Maine: Orono, Maine, University of Maine, M.S. Thesis, 53 p. 


\section{Appendix A. ArcObjects programming code for the macro developed to generate a sampling grid in ArcMap 8.1.}

Attribute VB_Name = "Grid"

'++ This program will create a randomized grid a specified length in meters

'++ The origin is the lower left hand corner of the coverage and is randomly

' ++ located within a square grid-sized area at before the origin point so as to

'++ randomize the grid on the surface

'++ Written by: Andrew Gilbert

'++ Patuxent Wildlife Research Center

'++ U. S. Geological Survey

'++ 196 Whitten Rd., Augusta, ME 04333

'++ February 22, 2005

'++ Version 1.2

Option Explicit

Private Sub Grid()

Dim mx As IMxDocument

Dim pID As New UID

Dim pEditor As IEditor

Dim pFeatLayer As IFeatureLayer2

Dim pDataset As IDataset

Dim pActiveView As IActiveView

Dim pLayer As ILayer

Dim pEnvelope As IEnvelope2

Dim GridEnvelope As IEnvelope2

Dim pFeatWrk As IFeatureWorkspace

Dim pFeatCls As IFeatureClass

Dim pFeatCurs As IFeatureCursor

Dim pFeatBuff As IFeatureBuffer

Dim pFeat As IFeature

Dim pEnumDatasetName As IEnumDatasetName

Dim pDatasetName As IDatasetName

Dim bfilefound As Boolean

Dim deletefcresp, response As Integer

Dim layer_selected As ILayer2

Dim pGridLayer As IFeatureLayer

Dim Gridtext, Gridsizetotext As String

Dim Gridsize, lowerX, lowerY, upperX, upperY As Double

Dim X1, Y1, X2, Y2 As Double

Dim gridPT, fromPt As IPoint

Dim startX, startY, randX, randY As Double

Dim GridIDNum As Integer

Dim pPointCollection As IPointCollection

Dim pPolygon As IPolygon

Dim polyset As esriCore.ISet

Dim pUnknown As IUnknown

Dim pArea As IArea

Dim centerPT As IPoint

Dim pFilter As ISpatialFilter 
Dim pPtFeatCurs As IFeatureCursor

Dim pPtFeature As IFeature

Dim pFeatclsboundary As IFeatureClass

MsgBox "This program will create a systematic grid of M meters “ \& vbNewLine $\&$ "on a side and randomly place the lower left corner up to M meters " \& vbNewLine $\&$ "along the $\mathrm{X}$ axis and $\mathrm{M}$ meters from the $\mathrm{Y}$ axis to randomize the grid." \& vbNewLine \& vbNewLine \& "Program written by: Andrew Gilbert" \& vbNewLine \& "Patuxent Wildlife Research Center, USGS" \& vbNewLine \& "Ver. 1.2" \& vbNewLine \& vbNewLine \& "Please select a layer for the extent. ", 0, "Random Systematic Sample"

Randomize

Set $\mathrm{mx}=$ ThisDocument

Set layer_selected $=$ mx.SelectedLayer

If layer_selected Is Nothing Then

Else

Err.Raise 91, ,"No layer selected." \& vbNewLine \& "Select a layer in the Table of Contents"

Set pLayer $=\mathrm{mx}$.SelectedLayer

pID = "esriCore.Editor"

End If

Set pEditor $=$ Application.FindExtensionByCLSID $(\mathrm{pID})$

'++ Calls the editor for editing

If $\mathrm{pEditor}$.EditState $=$ esriStateEditing Then

MsgBox "You are already editing something - Stop editing first."

Exit Sub

End If

'++ Determines if the selected layer is a feature layer

If TypeOf pLayer Is IFeatureLayer Then

Set $\mathrm{pFeatLayer}=$ pLayer

Set pDataset $=$ pFeatLayer.FeatureClass

Set $\mathrm{pFeatclsboundary}=\mathrm{pDataset}$

pEditor.StartEditing pDataset.Workspace

pEditor.StartOperation

Else

MsgBox "You must select a feature layer!", vbExclamation

Exit Sub

End If

Set $\mathrm{pEnvelope}=$ pLayer.AreaOfInterest

lowerX = pEnvelope. $x \min$

lowerY = pEnvelope.ymin

upperX = pEnvelope $\cdot \mathrm{x} \max$

upperY $=$ pEnvelope.ymax

++ Enter the grid size

Gridsize = Val(InputBox("Please enter the grid size in meters: ", "Gridsize"))

' ++ if cancel, then stop the process

If Gridsize $=0$ Then

pEditor.StopOperation "Grid"

pEditor.StopEditing (False)

MsgBox "Process cancelled."

Exit Sub

End If

Gridsizetotext $=$ Format $($ Round $($ Gridsize $))$ 
Gridtext = "Sampling_grid_" \& Gridsizetotext \& "m"

startX $=$ lowerX $-\mathrm{Rnd}() *$ Gridsize

start $\mathrm{Y}=$ lowerY $-\mathrm{Rnd}() *$ Gridsize

Set GridEnvelope $=$ pEnvelope. Envelope

GridEnvelope $. x \min =$ lowerX - Gridsize -1

GridEnvelope $. y \min =$ lowerY - Gridsize -1

GridEnvelope $. x \max =$ upperX + Gridsize +1

GridEnvelope.ymax $=$ upperY + Gridsize +1

'++ Determine if the featurclass already exists, if not create it

bfilefound $=$ False

Set $\mathrm{pEnumDatasetName}=$ pDataset .Workspace . DatasetNames (esriDTFeatureClass $)$

Set $\mathrm{pDatasetName}=\mathrm{pEnumDatasetName}$. Next

Do Until (pDatasetName Is Nothing Or bfilefound = True)

If pDatasetName. Name $=$ Gridtext Then bfilefound $=$ True

Set $\mathrm{pDatasetName}=\mathrm{pEnumDatasetName} \cdot \mathrm{Next}$

Loop

If bfilefound $=$ False Then

Else

Create_grid GridEnvelope, Gridtext '++ Create the grid featureclass

deletefcresp = MsgBox(“Sampling grid file already exists.” \& vbNewLine \&

"Ok to delete features? (Hit NO to Exit)", vbYesNo)

If deletefcresp $=v b$ No Then " ++ Stop process and cancel out of program

pEditor.StopOperation "Add center points"

pEditor.StopEditing (False)

MsgBox "Process cancelled."

Exit Sub

End If

End If

'++ Determine if the Sampling_grid feature class exists, delete data if so

Set $\mathrm{pFeatWrk}=\mathrm{pDataset}$.Workspace

Set $\mathrm{pFeatCls}=\mathrm{pFeatWrk}$.OpenFeatureClass $($ Gridtext $)$

If deletefcresp $=\mathrm{vb}$ Yes Then ' ++ Delete records in the file first

Set $\mathrm{pFeatCurs}=\mathrm{pFeatCls}$.Search $($ Nothing, False $)$

Set $\mathrm{pFeat}=\mathrm{pFeatCurs}$.NextFeature

Do Until pFeat Is Nothing

pFeat.Delete

Loop

Set $\mathrm{pFeat}=\mathrm{pFeatCurs}$.NextFeature

pFeatCurs.Flush

End If

Set pPointCollection $=$ New Polygon

Set polyset $=$ New esriCore .Set

$\mathrm{X} 1=\operatorname{start} \mathrm{X}$

$\mathrm{X} 2=\operatorname{start} \mathrm{X}+$ Gridsize

$\mathrm{Y} 1=\operatorname{start} \mathrm{Y}$

$\mathrm{Y} 2=\operatorname{start} \mathrm{Y}+$ Gridsize

'++ Create each grid polygon by starting at a the lower left starting point and

'++ creating towards the upper right side until the grid extends beyond the current envelope

Do While $\mathrm{Y} 1<$ upperY

Do While X1 < upperX

Set gridPT $=$ New Point

gridPT.x $=\mathrm{X} 1$ 


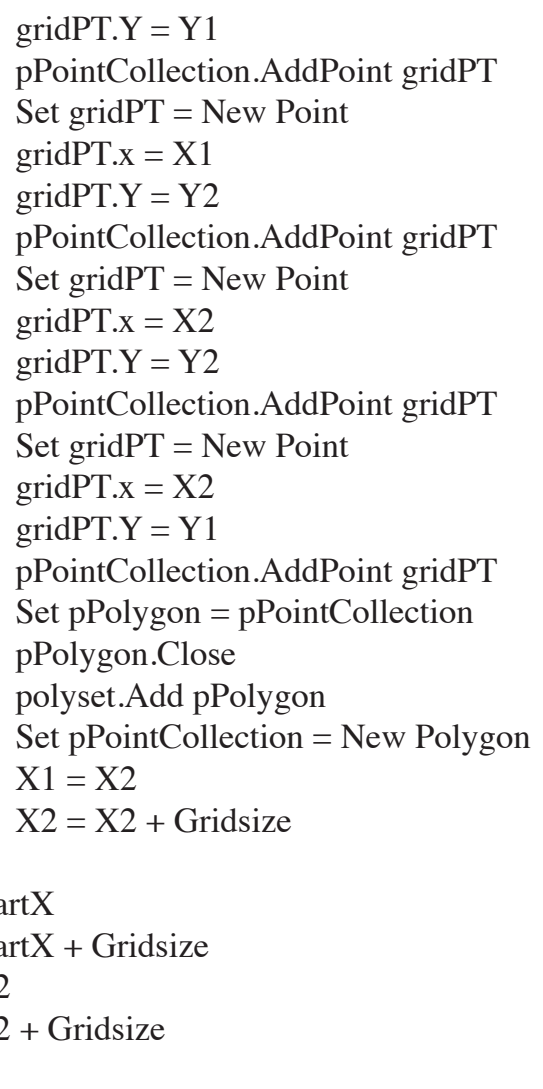

'++ Store the polygons in the Sampling_grid featureclass

Set $\mathrm{pFeatCurs}=\mathrm{pFeatCls}$.Insert $($ True $)$

Set $\mathrm{pFeatBuff}=\mathrm{pFeatCls}$.CreateFeatureBuffer

polyset.Reset

Set $\mathrm{pUnknown}=$ polyset.Next

GridIDNum $=0$

Do Until pUnknown Is Nothing

Set $\mathrm{pArea}=$ pUnknown

Set centerPT $=$ New Point

Set centerPT $=$ pArea.Centroid

Set $\mathrm{pFilter}=$ New SpatialFilter

With pFilter

$$
\begin{aligned}
& \text { Set } . \text { Geometry = centerPT } \\
& \text {.GeometryField }=\text { "Shape" } \\
& \text {.SpatialRel = esriSpatialRelWithin }
\end{aligned}
$$

End With

Set $\mathrm{pPtFeatCurs}=\mathrm{pFeatclsboundary.Search}(\mathrm{pFilter}$, False $)$

Set $\mathrm{pPtFeature}=\mathrm{pPtFeatCurs.NextFeature}$

'++ If the center point falls within the boundaries of the park

'++ then save the grid to the feature class and write the center $\mathrm{X}$ and $\mathrm{Y}$

'++ as well as random $\mathrm{X}$ and $\mathrm{Y}$ coords for use in sampling

If Not pPtFeature Is Nothing Then

GridIDNum $=$ GridIDNum +1

Set $\mathrm{pFeatBuff}$.Shape $=$ pUnknown

pFeatBuff.Value $(4)=$ centerPT.x

pFeatBuff.Value $(5)=$ centerPT.Y

Set pPolygon $=$ New Polygon

Set pPolygon $=$ pUnknown

Set fromPt $=$ New Point 
pPolygon.QueryFromPoint fromPt ' ++ starting poly pt

'++ random coords within the grid

$\operatorname{randX}=$ fromPt.X $+\mathrm{Rnd}() *$ Gridsize

rand $\mathrm{Y}=$ fromPt. $\mathrm{Y}+\mathrm{Rnd}() *$ Gridsize

pFeatBuff.Value $(6)=\operatorname{randX}$

pFeatBuff.Value $(7)=\operatorname{rand} Y$

pFeatBuff.Value $(8)=$ GridIDNum

pFeatCurs.InsertFeature pFeatBuff

End If

pFeatCurs.Flush

Loop

Set $\mathrm{pUnknown}=$ polyset. Next

'++ Stop the Edit session and ask to save edits.

response $=$ MsgBox(“Would you like to save edits?", vbYesNo)

If response $=$ vbYes Then

pEditor.StopOperation “"

pEditor.StopEditing (True)

MsgBox "Edits were saved"

Else

pEditor.StopOperation “"”

pEditor.StopEditing (False)

MsgBox "You DID NOT save the edits"

Exit Sub

End If

'++ Open the Sample_points fc in a new layer

Set pGridLayer $=$ New FeatureLayer

Set pGridLayer.FeatureClass $=$ pFeatCls

pGridLayer Name $=$ pFeatCls.AliasName

pGridLayer. Visible $=$ True

mx.AddLayer pGridLayer

Set $\mathrm{pActiveView}=\mathrm{mx}$.ActiveView

pActiveView.Refresh

\section{Exit Sub}

ErrorHandler:

Select Case Err.Number

Case Is $<>0$

End Select

MsgBox "Error: " \& Err.Description, vbCritical, "Error " \& Err.Number

If $\mathrm{pEditor}$.EditState $=$ esriStateEditing Then pEditor.StopOperation "Error handler"

End If pEditor.StopEditing (False)

Err.Clear

Exit Sub

End Sub 
Sub Create_grid(ByVal CreateEnv As IEnvelope, ByVal Gridname As String)

'++ This piece of code creates a new Fields collection, sets the number of Field(s) in the Fields collection

'++ and sets the Field at each position in the Fields collection, and creates a new FeatureClass

Dim pFields As IFields

Dim pField As IField

Dim pFieldsEdit As IFieldsEdit

Dim pFieldEdit As IFieldEdit

Dim pGeoDef As IGeometryDef

Dim pGeoDefEdit As IGeometryDefEdit

Dim pSpRef As ISpatialReference

Dim pSpRFc As SpatialReferenceEnvironment

Dim pPCS As IProjectedCoordinateSystem

Dim pGridWrkFact As IWorkspaceFactory2

Dim pGridWork As IWorkspace

Dim pGridFeatWork As IFeatureWorkspace

Dim pGridDataset As IDataset

Dim pGridFeatCls As IFeatureClass

Dim pGridLayer As ILayer

Dim strFileloc As String

Dim xmin, ymin, xmax, ymax As Double

strFileloc $=$ GetLayerPath

Set $\mathrm{pGridWrkFact}=$ New AccessWorkspaceFactory

Set pGridFeatWork $=$ pGridWrkFact .OpenFromFile $($ strFileloc, 0$)$

Set $\mathrm{pFields}=$ New Fields

Set $\mathrm{pFieldsEdit}=$ pFields

pFieldsEdit. FieldCount $=9$

$\mathrm{xmin}=$ CreateEnv. $\mathrm{xmin}$

$\mathrm{ymin}=$ CreateEnv.ymin

$\mathrm{xmax}=$ CreateEnv $\cdot \mathrm{xmax}$

ymax $=$ CreateEnv.ymax

Set $\mathrm{pSpRFc}=$ New SpatialReferenceEnvironment

Set pPCS $=$ pSpRFc.CreateProjectedCoordinateSystem(esriSRProjCS_NAD1983UTM_18N)

pPCS.SetDomain xmin, xmax, ymin, ymax

Set $\mathrm{pSpRef}=\mathrm{pPCS}$

'++ create new Field $(0)$

Set $\mathrm{pField}=$ New Field

Set $\mathrm{pFieldEdit}=$ pField

With pFieldEdit

.IsNullable $=$ False

.Name = "OID"

.Type $=$ esriFieldTypeOID

End With

Set pFieldsEdit.Field $(0)=$ pField

'++ Create geometry definition for FeatureClass

Set $\mathrm{pGeoDef}=$ New GeometryDef

Set $\mathrm{pGeoDefEdit}=\mathrm{pGeoDef}$

With pGeoDefEdit

.AvgNumPoints $=1$

.GeometryType $=$ esriGeometryPolygon

. GridCount $=1$ 


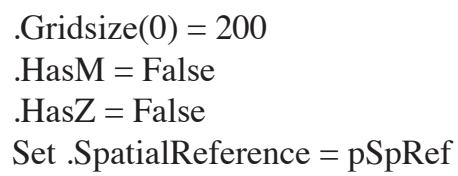

End With

'++ Create shape field

Set pField $=$ New Field

Set $\mathrm{pFieldEdit}=\mathrm{pField}$

With pFieldEdit

.Name = "Shape"

.Type $=$ esriFieldTypeGeometry

Set. GeometryDef $=$ pGeoDef

.IsNullable $=$ True

. Required $=$ True

End With

Set $\mathrm{pFieldsEdit.Field}(1)=\mathrm{pField}$

'++ Create new Field(2)

Set $\mathrm{pField}=$ New Field

Set $\mathrm{pFieldEdit}=\mathrm{pField}$

With pFieldEdit

.IsNullable $=$ True

.Name $=$ "Sample"

.Editable $=$ True

.Type $=$ esriFieldTypeInteger

End With

Set $p$ FieldsEdit Field $(2)=$ pField

'++ Create new Field(3)

Set $\mathrm{pField}=$ New Field

Set $\mathrm{pFieldEdit}=\mathrm{pField}$

With pFieldEdit

.IsNullable $=$ True

.Name = "Sample_type"

Editable $=$ True

.Type $=$ esriFieldTypeString

End With

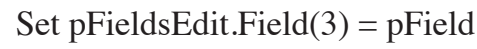

'++ Create new Field(4)- center X coord

Set $\mathrm{pField}=$ New Field

Set $\mathrm{pFieldEdit}=\mathrm{pField}$

With pFieldEdit

.IsNullable $=$ True

.Name $=$ "Centroid_X"

Editable $=$ True

.Type $=$ esriFieldTypeDouble

End With

Set pFieldsEdit.Field $(4)=$ pField

'++ Create new Field(5)- center Y coord

Set pField $=$ New Field

Set $\mathrm{pFieldEdit}=\mathrm{pField}$

With pFieldEdit

.IsNullable $=$ True 
Name $=$ "Centroid_Y"

.Editable $=$ True

End With

.Type $=$ esriFieldTypeDouble

Set pFieldsEdit.Field $(5)=$ pField

'++ Create new Field(6)- random X coord

Set $\mathrm{pField}=$ New Field

Set $\mathrm{pFieldEdit}=\mathrm{pField}$

With pFieldEdit

IsNullable $=$ True

.Name $=$ "Random_X"

.Editable $=$ True

.Type $=$ esriFieldTypeDouble

End With

Set pFieldsEdit.Field $(6)=$ pField

'++ Create new Field(7) - random Y coord

Set $\mathrm{pField}=$ New Field

Set $\mathrm{pFieldEdit}=\mathrm{pField}$

With pFieldEdit

.IsNullable $=$ True

.Name = "Random_Y"

Editable $=$ True

End With

.Type $=$ esriFieldTypeDouble

Set $p$ FieldsEdit.Field $(7)=$ pField

'++ Create new Field(8) - grid ID for linking habitat data

Set $\mathrm{pField}=$ New Field

Set $\mathrm{pFieldEdit}=\mathrm{pField}$

With pFieldEdit

.IsNullable $=$ True

.Name $=$ "GridID"

.Editable $=$ True

End With

.Type $=$ esriFieldTypeInteger

Set pFieldsEdit.Field $(8)=$ pField

"++ Create new feature class called "Sampling_grid"

Set pGridFeatCls = pGridFeatWork.CreateFeatureClass(Gridname, pFields, Nothing, Nothing, esriFTSimple, "Shape", "”)

End Sub

Function GetLayerPath() As String

'++ Adapted from ESRI online

'++ http://support.esri.com/index $. c f m ? f a=k n o w l e d g e b a s e . t e c h a r t i c l e s . a r t i c l e S h o w \& d=21579$

'++ Retrieves the full path for the selected layer and passes it as a string

Dim pDoc As IMxDocument

Dim pMap As IMap

Dim pLayer As IFeatureLayer

Dim pFc As IFeatureClass

Dim pDataset As IDataset

Dim pWorkspace As IWorkspace

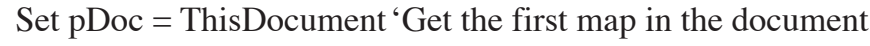


Set $\mathrm{pMap}=\mathrm{pDoc}$.FocusMap

'Get the first layer in the map

Set pLayer $=$ pMap.Layer $(0)$

'Get the feature class for the first layer

Set $\mathrm{pFc}=\mathrm{pLayer}$.FeatureClass

'Gets the dataset for standalone feature class

Set $\mathrm{pDataset}=\mathrm{pFc}$

Set $\mathrm{pWorkspace}=$ pDataset. Workspace

GetLayerPath $=$ pWorkspace.PathName

End Function 


\section{Appendix B. ArcObjects programming code for the macro developed to draw randomized systematic samples by strata in ArcMap 8.1.}

Attribute VB_Name = "Systematic_sampling"

'++ This program will assign $\mathrm{N}$ samples using a random systematic design to

‘++ a park grid. This procedure follows Paul Geissler's systematic sampling technique.

'++ Written by: Andrew Gilbert

'++ Patuxent Wildlife Research Center

'++ U. S. Geological Survey

'++ 196 Whitten Rd., Augusta, ME 04333

'++ February 22, 2005

'++ Version 1.6

Option Explicit

Dim pID As New UID

Dim mx As IMxDocument

Dim pMap As IMap

Dim pFeatCls As IFeatureClass

Dim pFeatLayer As IFeatureLayer

Dim pDataset As IDataset

Dim pLayer As ILayer

Dim pField As IField

Dim pFields As IFields

Dim pFieldEdit As IFieldEdit

Dim pEditor As IEditor

Dim pEditState, layerselected As Integer

Dim layer_selected As ILayer

Dim samplefield, sampletypefield As Long

Dim pSampleFeatCls As IFeatureClass

Dim pFeatWrk As IFeatureWorkspace

Dim pFeatCurs, pSamplePtFeatCurs As IFeatureCursor

Dim pFeatBuff, pSamplePtFeatBuff As IFeatureBuffer

Dim pFeature, pSamplePtFeat, $p$ Feat As IFeature

Dim pTable, pSampleTable As ITable

Private Sub Random_systematic_sample()

Dim addfieldresp, deletefcresp As Integer

Dim pRowBuffer As IRowBuffer

Dim pQueryFilt As IQueryFilter

Dim pEnumDatasetName As IEnumDatasetName

Dim pDatasetName As IDatasetName

Dim pGeom As IGeometry

Dim pFlds As IFields

Dim pFld As IField

Dim bfilefound As Boolean

Randomize

MsgBox "This program will sample a grid using a random “ \& 
"systematic sampling procedure. " \& vbNewLine \& vbNewLine \&

"Program written by: Andrew Gilbert" \& vbNewLine \& _

"Patuxent Wildlife Research Center, USGS" \& vbNewLine \& "Ver. 1.6” \& vbNewLine _

\& vbNewLine \& "Please select the grid layer. ", 0, "Random Systematic Sample"

Set $\mathrm{mx}=$ ThisDocument

Set layer_selected $=\mathrm{mx}$.SelectedLayer

If layer_selected Is Nothing Then

Err.Raise 91, , "No layer selected." \& vbNewLine \& "Select the grid layer in the Table of Contents"

Else

Set $\mathrm{pLayer}=\mathrm{mx}$. SelectedLayer

$\mathrm{pID}=$ "esriCore.Editor"

End If

Set $\mathrm{pEditor}=$ Application. FindExtensionByCLSID(pID)

'++ Calls the editor for editing

If pEditor.EditState $=$ esriStateEditing Then

MsgBox "You are already editing something - Stop editing first."

Exit Sub

End If

'++ Determines if the selected layer is a feature layer

If TypeOf pLayer Is IFeatureLayer Then

Set $\mathrm{pFeatLayer}=$ pLayer

Set pDataset $=$ pFeatLayer.FeatureClass

Set $\mathrm{pTable}=$ pDataset

Else

Set $\mathrm{pFeatCls}=\mathrm{pDataset}$

MsgBox "You must select a feature layer!", vbExclamation

Exit Sub

End If

Set $\mathrm{pFields}=$ pTable.Fields

samplefield = pFields.FindField("Sample")

sampletypefield = pFields.FindField("Sample_type")

If $-1=$ samplefield Then

MsgBox "Grid sample field does not exist.” \& vbNewLine \&

"Create sample and sample_type fields!"

'++ Stop process and cancel out of program

MsgBox "Process cancelled.", vbExclamation

Exit Sub

End If

'++ If the Grid_sample field exists, begin the sampling procedure

Set pQueryFilt $=$ New QueryFilter

pQueryFilt.WhereClause = "[SAMPLE] $>0$ "

Set $\mathrm{pFeatCurs}=$ pFeatCls.Update $(\mathrm{pQueryFilt}$, False $)$

Set $\mathrm{pFeat}=$ pFeatCurs.NextFeature

'++ If sample exist: delete old samples, else new samples will be added

If Not pFeat Is Nothing Then

addfieldresp = MsgBox("Sample already exists.” \& vbNewLine \&

"Do you want to delete the samples?" \& vbNewLine \&

"No to keep samples and add new ones to them.", vbYesNo)

If addfieldresp $=$ vbYes Then

Do Until pFeat Is Nothing

pFeat.Value $($ samplefield $)=$ Null 


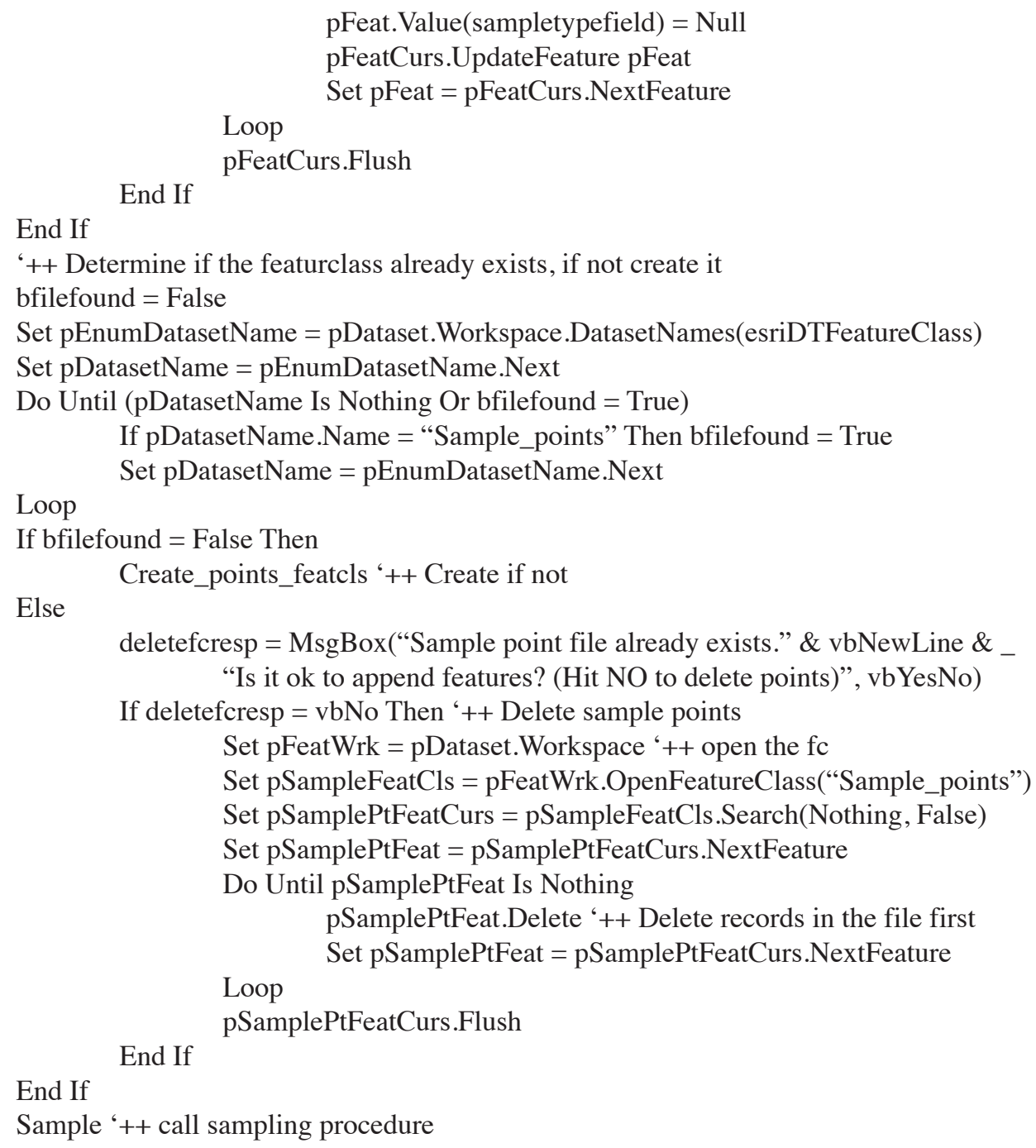

Exit Sub

ErrorHandler:

Select Case Err.Number

Case Is $=91$

MsgBox "Error: Layer not selected!", vbCritical, "Error “ \& Err.Number Case Is $<>91$ Or 0

MsgBox "Error: " \& Err.Description, vbCritical, "Error " \& Err.Number

If pEditor.EditState = esriStateEditing Then pEditor.StopOperation "Error handler"

End If pEditor.StopEditing (False)

End Select

Err.Clear

Exit Sub

End Sub

Private Sub Sample()

'++ Assign a user specified number of random systematic samples to the grid 
On Error GoTo ErrorHandler

Dim response As Integer

Dim i, samplenum, samples, $\mathrm{N}$ As Long

Dim Cent_Xfield, Cent_Yfield, Rand_Xfield, Rand_Yfield As Long

Dim X_coord, Y_coord As Double

Dim k, randstart, samplinglength As Double

Dim sample_resp, habitat_sampled As String

Dim pPoint As IPoint

Dim pSampleLayer As IFeatureLayer

Dim pActiveView As IActiveView

Dim pHabitatQuery As IQueryFilter

Dim proceed As Boolean

Set $\mathrm{mx}=$ ThisDocument

Set $\mathrm{pLayer}=\mathrm{mx}$.SelectedLayer

Set $\mathrm{pFeatLayer}=$ pLayer

Set $\mathrm{pDataset}=\mathrm{pFeatLayer}$.FeatureClass

Set $\mathrm{pTable}=\mathrm{pDataset}$

Set $\mathrm{pFeatCls}=\mathrm{pDataset}$

'++ Input the habitat class to sample

habitat_sampled $=$ “"”

habitat_sampled = InputBox(“Enter the habitat to generate sample points for: “, "Habitat”)

samples $=$ Len(habitat_sampled)

If samples $=0$ Then ' ++ If user cancels out - then exit program.

MsgBox "Goodbye.", vbExclamation

Exit Sub

End If

'++ select those grid cells of habitat to be sampled

Set pHabitatQuery $=$ New QueryFilter

pHabitatQuery. WhereClause = "[HABITAT] Like "” \& habitat_sampled \& “"”

$\mathrm{N}=$ pFeatCls.FeatureCount(pHabitatQuery) "++ Determine the number of grids to sample

MsgBox "There are “ \& N \& “ “ \& habitat_sampled \& " grids to select from.”, vbExclamation

proceed $=$ False

Do Until proceed $=$ True

'++ Input the number of samples to generate

sample_resp $=0$

sample_resp = InputBox(“Enter the number of sampling points: “, "Sample Number")

samples $=\operatorname{Int}(\operatorname{Val}($ sample_resp $))$

If samples $=0$ Then " ++ If user cancels out - then exit program.

MsgBox "Goodbye.", vbExclamation

Exit Sub

End If

If $\mathrm{N}<$ samples Then

MsgBox "There are only " \& N \& " grids with this habitat. " \& vbNewLine \& "You can't exceed the number of grids!", vbCritical

Else: proceed $=$ True

End If

Loop

Set $\mathrm{pFeatWrk}=\mathrm{pDataset}$. Workspace

Set pSampleFeatCls = pFeatWrk.OpenFeatureClass("Sample_points")

Set $\mathrm{pSamplePtFeatCurs}=\mathrm{pSampleFeatCls}$.Insert(True)

Set pSamplePtFeatBuff $=$ pSampleFeatCls. CreateFeatureBuffer 


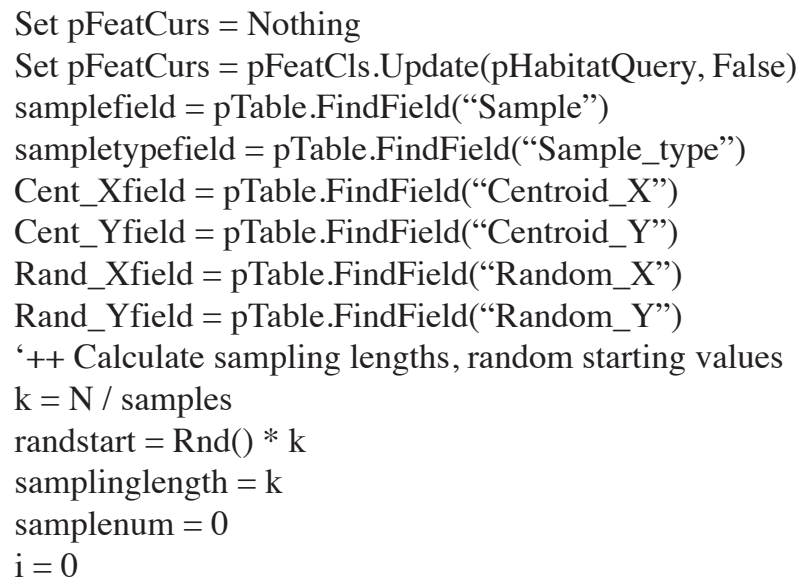

'++ Assign a user defined number of samples to sample a grid systematically based on

'++ a random starting point

Set $\mathrm{pFeat}=\mathrm{pFeatCurs.NextFeature}$

Do Until pFeat Is Nothing

$\mathrm{i}=\mathrm{i}+1$

Application.StatusBar.Message $(0)=\operatorname{Str}(i) \&$ " grids processed"

If $(\mathrm{i}+\mathrm{k}-$ randstart $)>=$ samplinglength Then '++ If sample, then set to sampling \#

samplinglength $=$ samplinglength $+\mathrm{k}$

samplenum $=$ samplenum +1

pFeat.Value $($ samplefield $)=$ samplenum

pFeat.Value $($ sampletypefield $)=$ pFeat.Value $($ sampletypefield $) \&$ habitat_sampled \&

“_systematic_“ \& Format(samplenum)

pFeatCurs.UpdateFeature pFeat

'++ Add new points to the new sample point file

Set $\mathrm{pPoint}=$ New Point

X_coord $=$ pFeat.Value $($ Rand_Xfield $)$

Y_coord = pFeat.Value $($ Rand_Yfield $)$

pPoint.PutCoords X_coord, Y_coord

Set $\mathrm{pSamplePtFeatBuff}$.Shape $=$ pPoint

pSamplePtFeatBuff.Value (2) = pFeat.Value(samplefield) ' ++ Add the sample number

pSamplePtFeatBuff.Value $(3)=$ pFeat.Value (sampletypefield)

pSamplePtFeatBuff.Value $(4)=$ pFeat.Value(Cent_Xfield)

pSamplePtFeatBuff.Value (5) = pFeat.Value(Cent_Yfield)

pSamplePtFeatBuff.Value $(6)=$ pFeat.Value(Rand_Xfield $)$

pSamplePtFeatBuff.Value $(7)=$ pFeat.Value(Rand_Yfield $)$

pSamplePtFeatCurs.InsertFeature pSamplePtFeatBuff

pSamplePtFeatCurs.Flush

End If

Set $\mathrm{pFeat}=\mathrm{pFeatCurs.NextFeature}$

Loop

pSamplePtFeatCurs.Flush

pFeatCurs.Flush

'++ Open the Sample_points fc in a new layer and display it

Set pSampleLayer $=$ New FeatureLayer

Set pSampleLayer.FeatureClass = pSampleFeatCls

pSampleLayer.Name $=$ pSampleFeatCls.AliasName

pSampleLayer.Visible $=$ True

mx.AddLayer pSampleLayer

Set $\mathrm{pActiveView}=\mathrm{mx}$. ActiveView

pActiveView.Refresh 
Exit Sub

ErrorHandler:

Select Case Err.Number

Case Is $<>0$

$$
\text { MsgBox "Error: “ \& Err.Description, vbCritical, "Error “ \& Err.Number }
$$

End Select

If $\mathrm{pEditor}$.EditState $=$ esriStateEditing Then pEditor.StopOperation "Error handler"

End If pEditor.StopEditing (False)

Err.Clear

Exit Sub

End Sub

Private Sub Create_points_featcls()

'++ Creates a new point featureclass for holding the sampling points centered

'++ at the centroid of the grid.

Dim pFieldsEdit As IFieldsEdit

Dim pGeoDef As IGeometryDef

Dim pGeoDefEdit As IGeometryDefEdit

Dim pSpRef As ISpatialReference

Dim pSpRFc As SpatialReferenceEnvironment

Dim pPCS As IProjectedCoordinateSystem

Dim pSampleWrkFact As IWorkspaceFactory2

Dim pSampleWork As IWorkspace

Dim pSampleFeatWork As IFeatureWorkspace

Dim pSampleDataset As IDataset

Dim pSampleLayer As ILayer

Dim strFileloc As String

strFileloc $=$ GetLayerPath

Set pSampleWrkFact $=$ New Access WorkspaceFactory

Set pSampleFeatWork $=$ pSampleWrkFact. OpenFromFile $($ strFileloc, 0$)$

Set $\mathrm{pFields}=$ New Fields

Set $\mathrm{pFieldsEdit}=$ pFields

pFieldsEdit.FieldCount $=8$

Set $\mathrm{pSpRFc}=$ New SpatialReferenceEnvironment

Set $\mathrm{pPCS}=$ pSpRFc.CreateProjectedCoordinateSystem(esriSRProjCS_NAD1983UTM_18N)

Set $\mathrm{pSpRef}=\mathrm{pPCS}$

'++ create new Field $(0)$

Set $\mathrm{pField}=$ New Field

Set $\mathrm{pFieldEdit}=$ pField

With pFieldEdit

$$
\begin{aligned}
& \text {.IsNullable }=\text { False } \\
& \text {.Name }=\text { "OID" } \\
& \text {.Type = esriFieldTypeOID }
\end{aligned}
$$

End With

Set pFieldsEdit.Field $(0)=$ pField

'++ Create geometry definition for FeatureClass

Set pGeoDef $=$ New GeometryDef

Set $\mathrm{pGeoDefEdit}=\mathrm{pGeoDef}$

With pGeoDefEdit

.AvgNumPoints $=1$ 


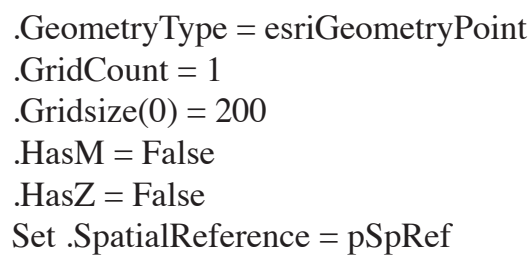

End With

'++ Create shape field

Set $\mathrm{pField}=$ New Field

Set $\mathrm{pFieldEdit}=$ pField

With pFieldEdit

.Name = "Shape"

.Type $=$ esriFieldTypeGeometry

Set. GeometryDef $=$ pGeoDef

.IsNullable $=$ True

. Required $=$ True

End With

Set $\mathrm{pFieldsEdit.Field}(1)=$ pField

'++ Create new Field(2)

Set $\mathrm{pField}=$ New Field

Set $\mathrm{pFieldEdit}=\mathrm{pField}$

With pFieldEdit

.IsNullable $=$ True

.Name $=$ "Sample"

.Editable $=$ True

End With

.Type $=$ esriFieldTypeInteger

Set pFieldsEdit.Field $(2)=$ pField

'++ Create new Field(3)

Set $\mathrm{pField}=$ New Field

Set $\mathrm{pFieldEdit}=\mathrm{pField}$

With pFieldEdit

$$
\begin{aligned}
& \text {.IsNullable }=\text { True } \\
& . \text { Name }=\text { "Sample_type" } \\
& . \text { Editable }=\text { True } \\
& \text {.Type = esriFieldTypeString }
\end{aligned}
$$

End With

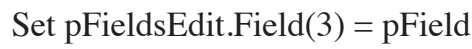

'++ Create new Field(4)

Set $\mathrm{pField}=$ New Field

Set $\mathrm{pFieldEdit}=$ pField

With pFieldEdit

.IsNullable $=$ True

.Name $=$ "Centroid_X"

.Editable $=$ True

End With

.Type $=$ esriFieldTypeDouble

Set $\mathrm{pFieldsEdit.Field}(4)=$ pField

'++ Create new Field(5)

Set $\mathrm{pField}=$ New Field

Set $\mathrm{pFieldEdit}=$ pField

With pFieldEdit

.IsNullable $=$ True

.Name $=$ "Centroid_Y"

.Editable $=$ True

.Type $=$ esriFieldTypeDouble 
End With

Set $\mathrm{pFieldsEdit.Field}(5)=$ pField

'++ Create new Field(6)

Set $\mathrm{pField}=$ New Field

Set $\mathrm{pFieldEdit}=\mathrm{pField}$

With pFieldEdit

.IsNullable $=$ True

.Name $=$ "Random_X"

Editable $=$ True

End With

.Type $=$ esriFieldTypeDouble

Set pFieldsEdit.Field $(6)=$ pField

'++ Create new Field(7)

Set $\mathrm{pField}=$ New Field

Set $\mathrm{pFieldEdit}=\mathrm{pField}$

With pFieldEdit

.IsNullable $=$ True

.Name $=$ "Random_Y"

Editable $=$ True

End With

.Type $=$ esriFieldTypeDouble

Set $p$ FieldsEdit.Field $(7)=p$ Field

"++ Create new feature class called "Sample_points"

Set pSampleFeatCls = pSampleFeatWork.CreateFeatureClass("Sample_points", pFields, Nothing, Nothing, esriFTSimple, "Shape", "”)

End Sub

Function GetLayerPath() As String

'++ Adapted from ESRI online. Retrieves the full path for the selected layer and passes it as a string

'++ http://support.esri.com/index.cfm?fa=knowledgebase. techarticles. articleShow\&d=21579

Dim pDoc As IMxDocument

Dim pMap As IMap

Dim pLayer As IFeatureLayer

Dim pDataset As IDataset

Dim $\mathrm{pFc}$ As IFeatureClass

Dim pWorkspace As IWorkspace

Set $\mathrm{pDoc}=$ ThisDocument

Set $\mathrm{pMap}=\mathrm{pDoc}$. FocusMap

Set $\mathrm{pLayer}=$ pMap $\cdot$ Layer $(0)$

'Get the first map in the document

Set $\mathrm{pFc}=$ pLayer.FeatureClass

'Get the first layer in the map

Set $\mathrm{pDataset}=\mathrm{pFc}$

'Get the feature class for the first layer

'Gets the dataset for standalone feature class

Set $\mathrm{pWorkspace}=\mathrm{pDataset}$. Workspace

GetLayerPath $=$ pWorkspace.PathName

End Function 


\section{Appendix C. Method employed for generating randomized systematic samples.}

\section{Creating the grid cell layer and strata layer}

The grid (orange cells) is generated by the program and saved as a data layer within the personal geodatabase that the boundary layer is saved within.

- Create a personal geodatabase and place a boundary data layer into it.

- Use the grid program to generate a grid $\mathrm{x}$-units on each side for each area of interest.

- The grid is automatically added to the map.

- Some grid cells have areas outside of the boundary and some areas of the park do not have grid cells (i.e., not all of the park is sampled).

Create a strata layer to use for assigning stratum to each grid cell based on the stratum occurring in greatest area within each cell. This is done through a combination of GIS and spreadsheet analysis.

- The strata layer is used to assign strata to grid cells.

- Clip the community type to the grid and then intersect the community type layer with the grid cell layer.

- Strata features are now split in each grid cell in the new intersected layer.

- The community type-grid intersect layer references the old grid cell ID and community type (strata).

- Summarized strata for each grid cell by outputting the data to Excel for summarization.

- Save as type "Text File" (DBF files can truncate data).

- Import to Microsoft Excel. 

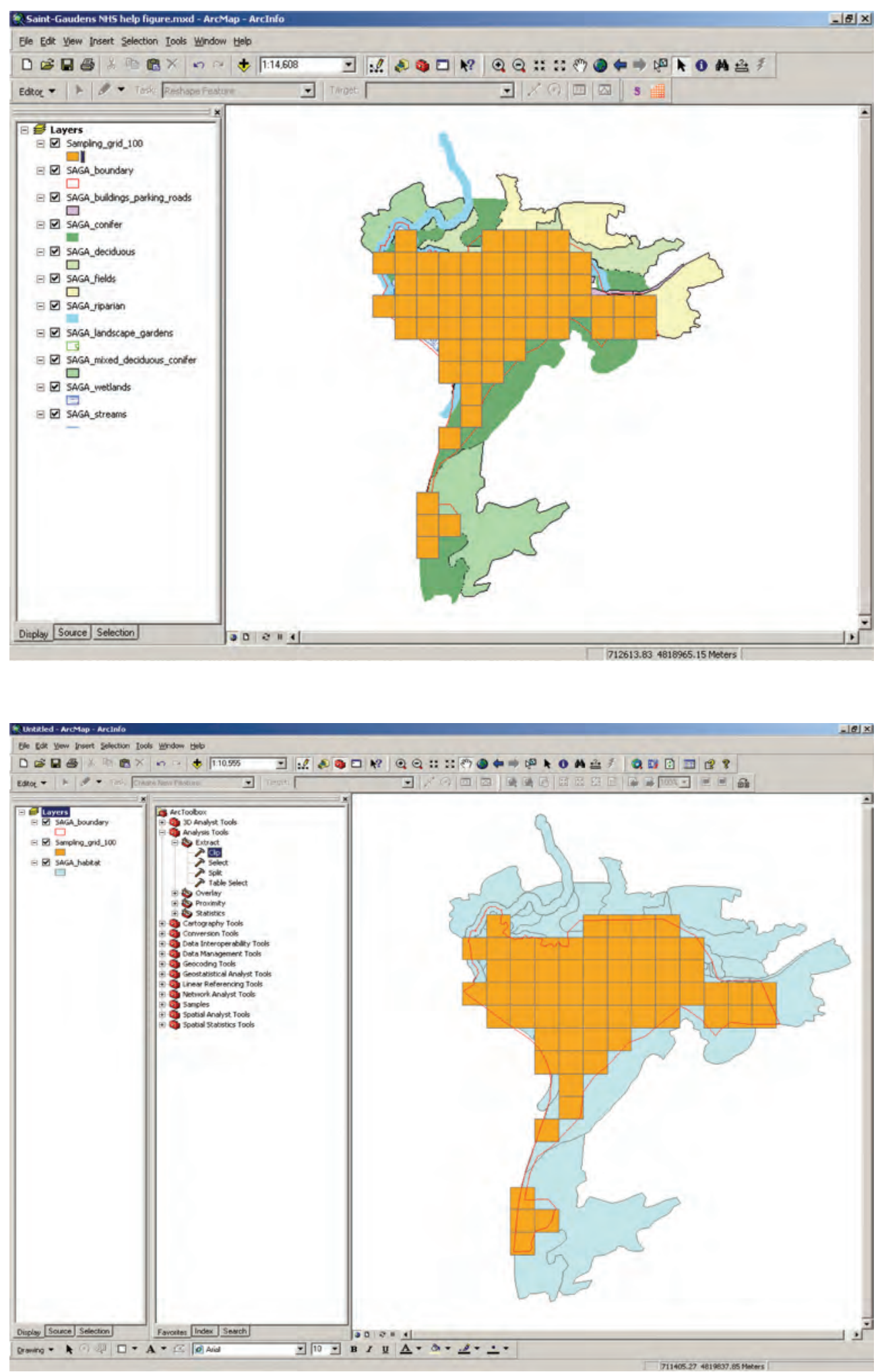

Figure C1. Separate strata layers (above) before being combined into (below) a single strata layer (light blue) overlain by an orange grid cell layer. 


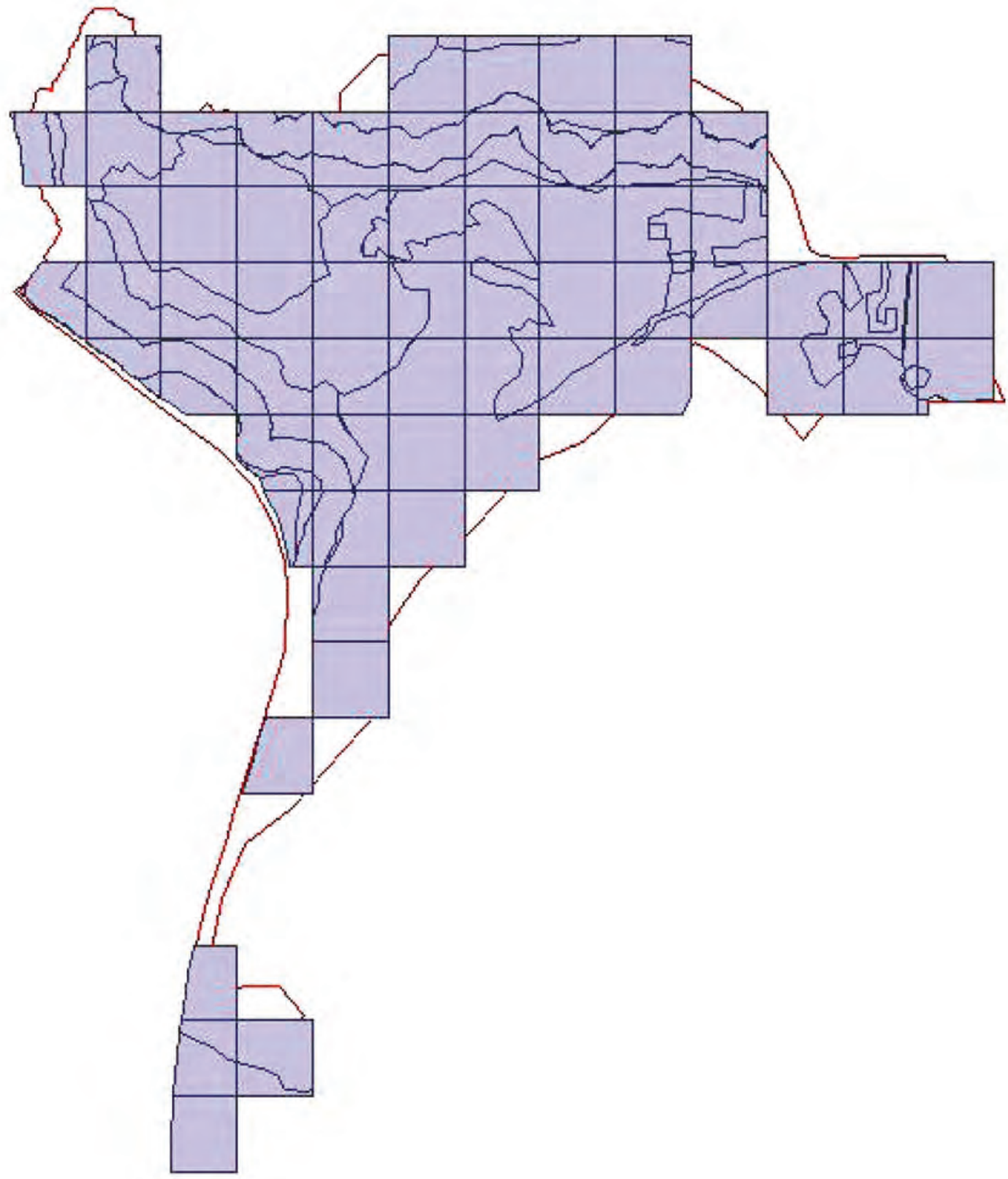

Figure C2. The clipped and intersected community type layer (lavender). The attributes from this layer are exported to Microsoft Excel to summarize strata in each grid cell. 


\section{Using Microsoft Excel to determine strata assignments}

- Using Microsoft Excel create a pivot table using the wizard as shown.

- Add GridID to the rows and strata to columns,

- Add polygon area to the data section and sum function to sum all strata pieces within each grid cell.

- This will allow you to determine the dominant type within a grid cell.

- The dominant type (by percent of area) is used to assign strata to each grid cell.

- The max function is used to find the stratum having the largest area in each grid cell.

- Save this worksheet as a text (.csv) file.

- Join the summary .csv file to the grid layer by the gridID.

- Copy the assigned strata for all grid cells to the strata field of the grid layer.

- Use the "Field Calculator", accessed through the attribute table to perform the copy.

- The strata field (blank normally) in the Sampling_grid_X layer can be assigned strata for all grid cells using the joined pivot table.

\section{Using the systematic sampling tool to draw sampling points}

- Use the systematic sampling tool to draw systematic samples for the previously generated grid cells.

- The sampling tool will request a stratum and number of sampling points; specify each for each stratum.

- Oversamples must be drawn at this point to ensure that points remain systematically distributed with respect to one another.

- A sampling point layer will automatically be created in the personal geodatabase and displayed on the map.

- Repeat for each stratum for which sampling points are necessary.

- GPS coordinates are generated and can be exported and viewed in a table or imported to a GPS for locating sampling points. 

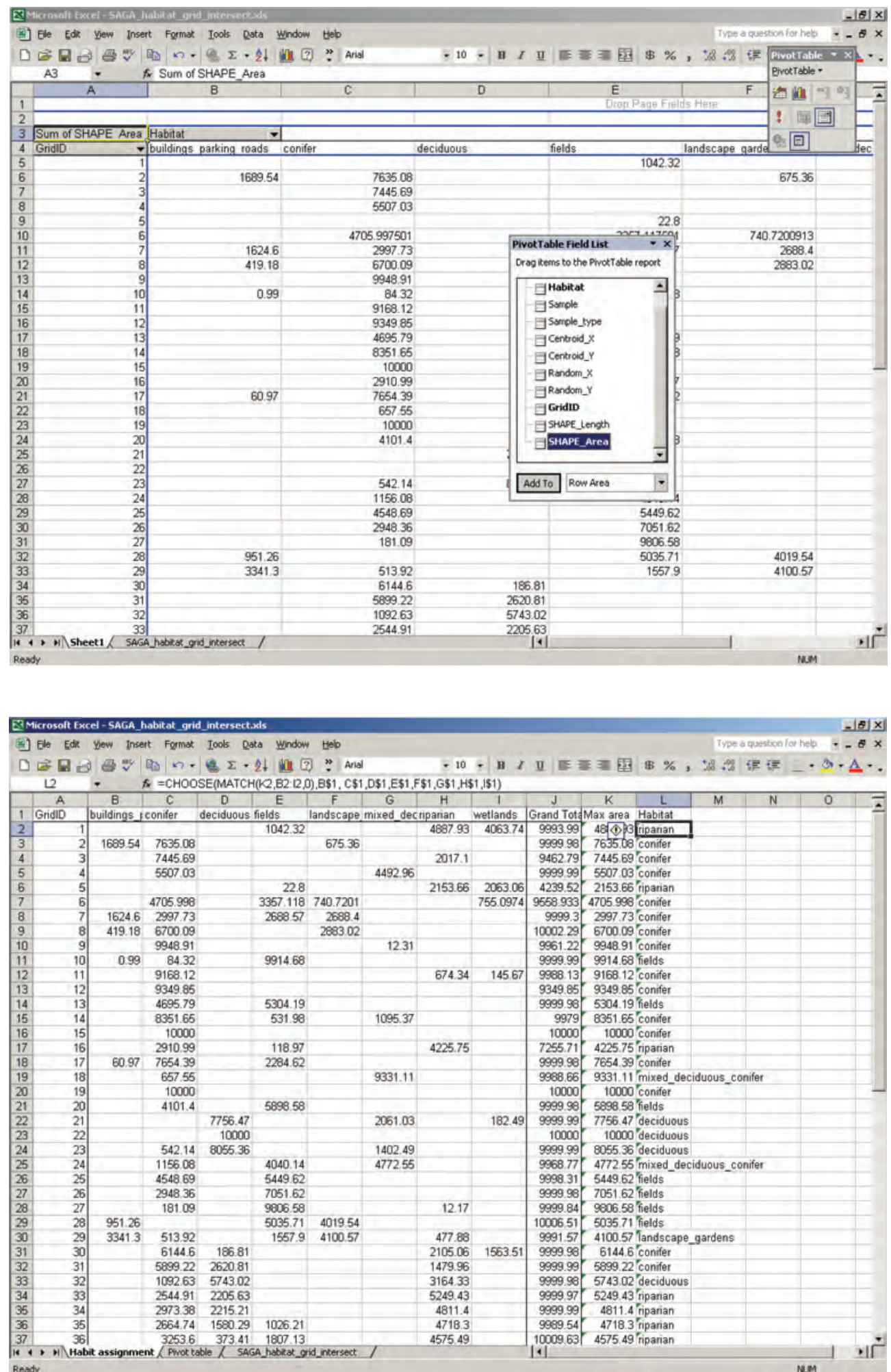

Figure C3. The strata summary table (above). Determining the max stratum for each grid cell based on the percentage (by area) for each stratum (below). 


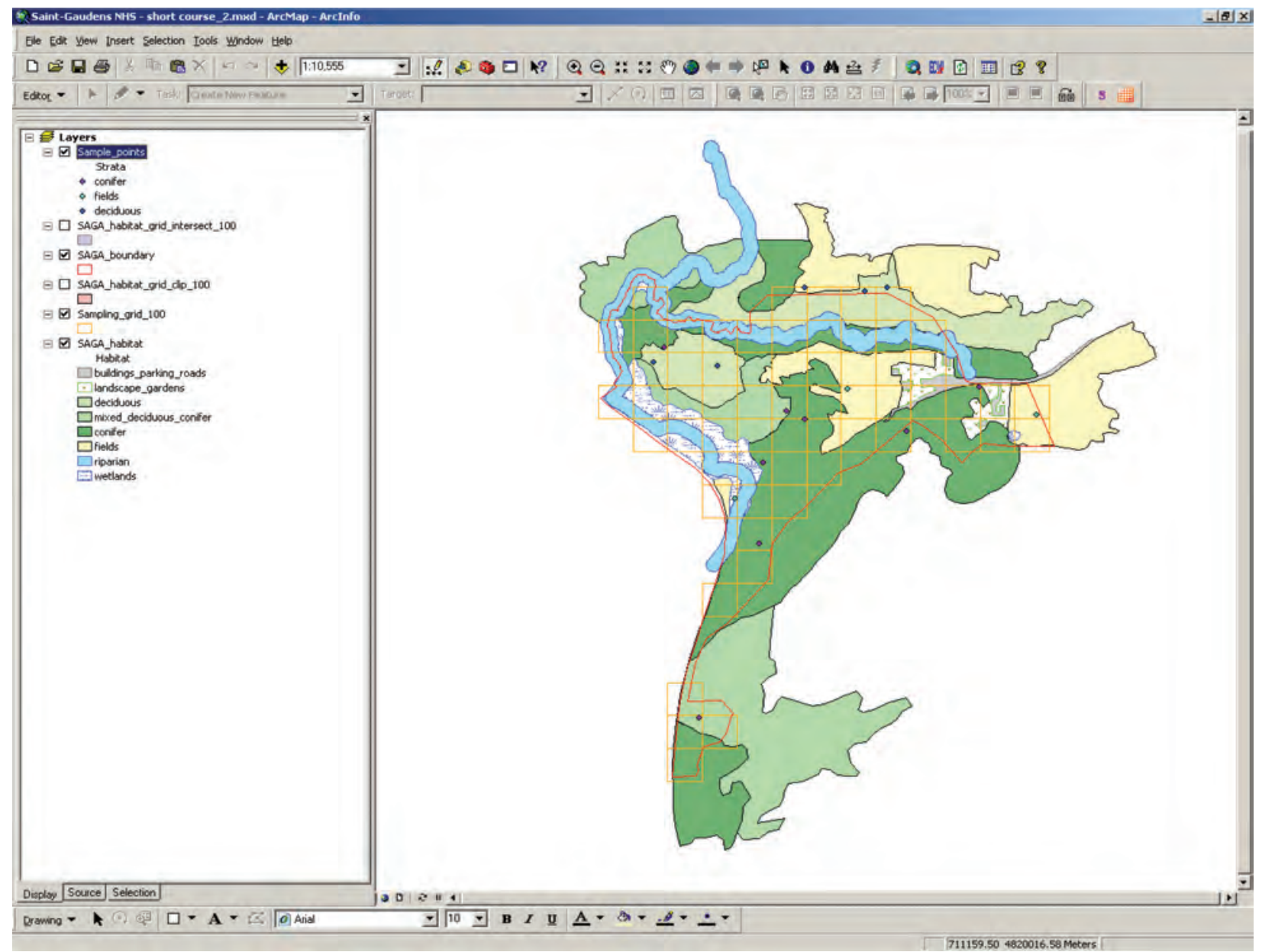

Figure C4. Sampling points created by the systematic sampling routine for several different strata. 


\section{Appendix D. Protocols for indirect measure sampling (hair traps, cubby boxes, and remote cameras).}

\section{HAIR TRAP}

EQUIPMENT LIST:

1. Chicken pieces, enough to replace at every station if necessary ( 24-28)

2. Glue board pieces $(1.5 \times 5 \mathrm{~cm})(\sim 40)$

3. Thumbtacks (handful)

4. Scent lure (1 bottle)

5. Cotton swabs (30)

6. Sample bags $(\sim 20)$

7. Permanent markers (2)

8. Cordless drill/screwdriver

9. Exterior wood screws - 3.5" (handful)

10. Sample map and coordinates to locate point

11. GPS with location of the station

12. Wooden boards (2)

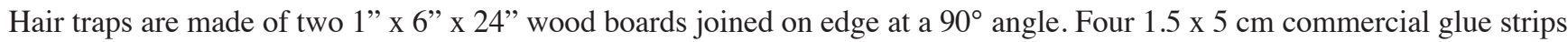
used for trapping mice are attached with thumbtacks $1 / 3$ the distance from the trap openings towards the peak of the trap. Traps are mounted vertically on trees or on the ground, when there are no trees. Bait is attached to the tree or laid on the ground in the middle of the trap.

\section{WHAT TO DO:}

1. Unscrew the trap and carefully check the glue boards for hair. If a board has hair, remove the tacks and place each glue strip with hair in its own sample bag or vial. Using a permanent marker, record the station, location, your initials, date, time, and where the sample came from (upper, lower, ground, or trap if it was stuck to the trap and not the glue boards) on the bag.

2. Check bait - there should be at least some bait - replace bait if necessary (one chicken part). Bait attaches by screw to the tree in the middle of the trap.

3. Re-scent every other check. Use a cotton swab to dab scent lure on the cotton cloth attached to the inside or outside of the trap. You need very little - this is powerful stuff! Place the swab near the trap.

4. Replace the glue boards. Four $1.5 \times 5 \mathrm{~cm}$ pieces of board are attached with thumbtacks $1 / 3$ the distance from the trap openings. Mount two pieces at each end toward the peak of the trap.

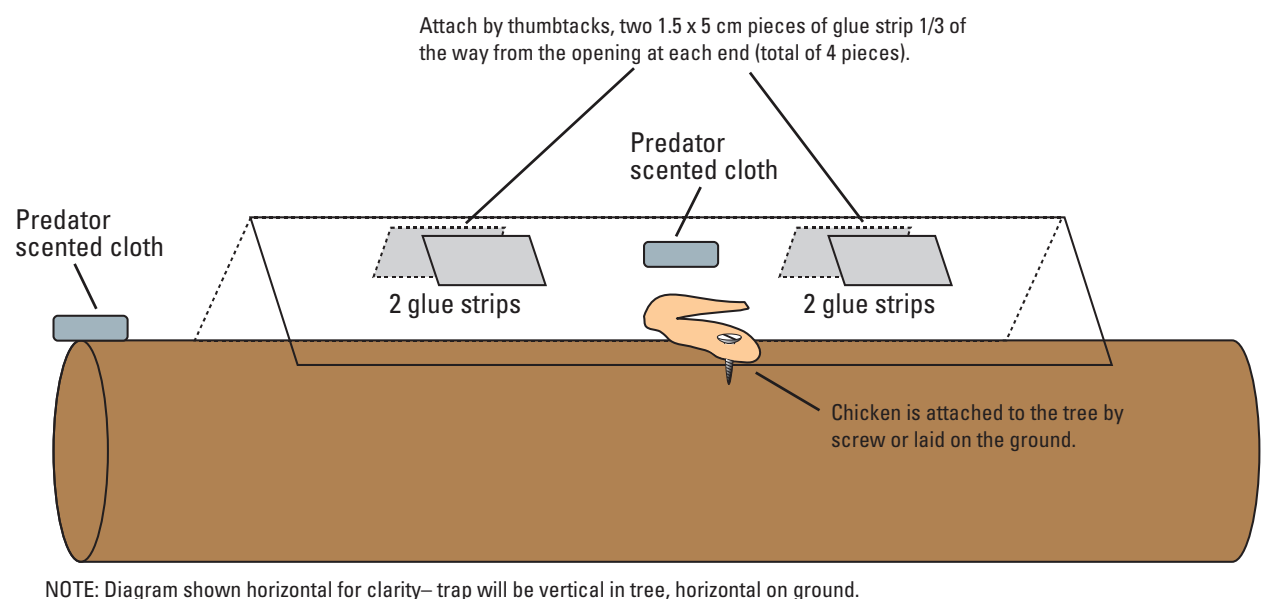

NOTE: Diagram shown horizontal for clarity- trap will be vertical in tree, horizontal on ground. 


\section{CUBBY BOX}

EQUIPMENT LIST:

1. Cat food ( 4 cans)

2. Sheets of contact paper or extra aluminum plates with sheets attached $(\sim 12)$

3. Plastic sheet protectors $(\sim 12)$

4. Permanent markers (2)

5. Scissors

6. Duct tape (1 roll)

7. Toner for sooting (1 full bottle)

8. Dry cloths

9. Scent lure (1 bottle)

10. Sample map and coordinates

11. GPS with locations of the station

12. Camera

13. Wood for constructing box

Cubby boxes consist of sooted aluminum plates to which contact paper (sticky side up) has been attached to the upper third of the plate and bait placed at the end of the plate. The plate is housed within a wooden box ( 32" x 9" x 9") with an entrance at one end. Animals track soot from the plate onto the contact paper when retrieving the bait.

\section{WHAT TO DO:}

1. Check the contact paper AND soot to determine if there are tracks present.

2. For tracks only on the contact paper: If tracks are present remove the entire plate with contact paper still attached. Record the station, location number, your initials, park code, date, and time on the back of the contact paper with a permanent marker and on the data sheet. Remove the contact paper from the plate and place it carefully in a sheet protector.

For contact paper with only rodent tracks - leave until the last check to remove unless these tracks obscure the paper. DO NOT THROW AWAY ANY TRACKS - RODENTS INCLUDED. At the last check, remove the contact sheet with mouse tracks and save as you would any other tracked contact sheet.

3. For tracks only on the soot: If the tracks on the soot are larger than a small rodent, you can lift this track with a small piece of contact paper or clear tape. First, photograph the tracks in place using something to gauge size (a folding rule is best, but a knife or pen will do). Try to stand directly over the aluminum plate for the photo with the gauge near the track itself. Take a wide angle photo of the entire plate, then a close up of the track. Angled photos are difficult to judge with respect to size and shape because of lens distortion. You can then lift the track by carefully placing a piece of contact paper (sticky side down) over the track. Do not move the contact paper at this point or it will smudge. Using your finger, press down all over the track and around the edges of the track. If you try to rub the track, it likely will smear due to movement. A second option is to take a picture. Photos are often better evidence (and easier to retrieve) than the lifted track, which can be hard to interpret.

4. For tracks on both contact sheet and soot: Make sure that the tracks on the soot are the same; you may have to lift tracks from the soot as well as collect the contact paper for those tracks when it appears that more than one species has visited the setup. This is not uncommon. If in doubt, collect the tracks from both. You do not need to collect rodent tracks from the soot at the end of sampling, but photographs are a good backup. Please collect any tracks that you are unsure of on any substrate. Please note-some weasels and squirrels have very small tracks that can easily go unnoticed.

5. Replace the sooted plate or re-soot if it has been heavily tracked or a good portion of the soot has been removed by wind, rain, or debris. You will likely have to wipe the old toner off first with a dry cloth.

- Replace the contact paper if you removed it or if it is dirty or wet so as not to be sticky.

- Wrap the sides of a piece of contact paper with protective film facing up around the top third of the plate, leaving about 3 inches of plate uncovered at the top for the bait.

- Tape the corners to the trackplate back. 
- Wipe the plate to make sure it is dry.

- Apply toner from a squeeze bottle in a straight line across one end plate to be sooted.

- Using your finger, tap the plate on the side without the toner while holding the plate at an angle $\left(\sim 45^{\circ}\right)$ to evenly distribute the toner across the tape.

- Remove the protective covering from the contact paper.

6. Check the bait - add bait if necessary (another can of cat food) to the space just beyond the contact paper. Raccoons often remove cans of bait from the box; look for the can nearby before replacing it.

7. Slide the sooted trackplate with contact paper and bait back into the cubby box.

8. Re-scent every other check. Use a cotton swab to dab scent lure onto the cotton cloth in the trap or outside it. Very little scent lure is needed. Leave the swab near the trap.

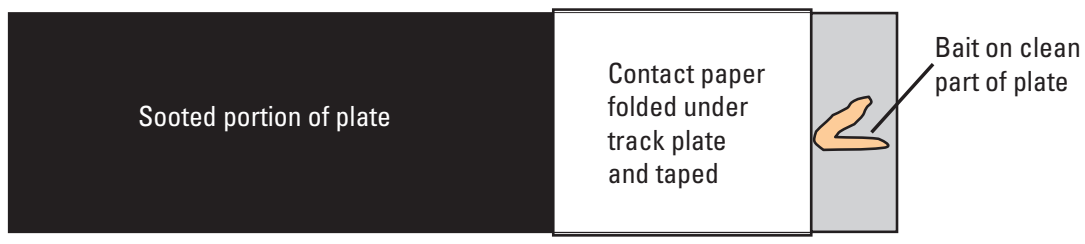




\section{REMOTE CAMERA}

EQUIPMENT LIST FOR ALL CAMERAS:

1. Chicken pieces $(\sim 12)$

2. Film -400 or 800 speed (4 rolls)

3. Permanent markers (2)

4. Lithium camera battery - CR123 (2)

5. C-cell batteries (8)

6. Extra camera control wire $-25^{\prime}$ with 3 prongs on one end (2)

7. Sample map and coordinates

8. GPS if unfamiliar with the location of the station

\section{ACTIVE INFRARED CAMERAS (TM 1550 OR 1500)}

Active Units have three parts: the transmitter (4" x 5" box with a single LED in the front center of the unit); a receiver (4" x 8" box with display - under camo tape); and a camera attached to the receiver by a long black cord.

1. Record the number of events. Note that a large number of added events ( $>100$ new) means that the unit is probably out of alignment - realignment procedures are detailed below.

2. Record the number of pictures taken. Note that the smaller Yashica cameras (black) with LCD display show the frame number to be taken (i.e., subtract 1 to get the number of pictures taken); the larger Canons (white) with dial display show the number of pictures actually taken.

3. Check the cord to make sure it is still intact; some rodents like to eat through these. Replace as necessary. The cord with three prongs connects to the front of the camera with the wire hanging down. The stereo jack plugs into the bottom of the receiver.

4. Make sure the units are still in alignment. The transmitter with LED in the middle should be pointed toward the side of the receiver where the infrared window (dark red plastic) is found.

To check alignment, press the [SETUP] button on the receiver until S.uP is displayed

- a red light on the side of the receiver will light up when the units are in alignment.

- to double check the alignment of the units walk over to the transmitter, loosen the strap, and turn the unit to the left. On the receiver you will notice that the light will be red and suddenly go out. This is the leftmost side of the infrared range. Repeat this procedure for the right side and up and down. By doing this you now know where the center of the range is and the unit should only be tightly affixed to the tree once the center of the range has been determined.

- placing the unit in setup mode will give you 4 minutes to depart the area before the unit begins recording information.

5. Check that the camera still has power; replace lithium battery as necessary.

6. Check the film in the camera. If 32 pictures or more of a 36 roll or 20 pictures of a 24 roll are exposed, then rewind (or take pictures until all are exposed) and replace with a fresh roll. Immediately write the park code, date, time, station, and location on the used roll of film. The rewind button on the smaller Yashica cameras (black) is on the bottom of the camera; use a pen or pencil to press the small grey button. The camera should show 0 when rewound. The Canon camera (white) does NOT have a rewind button, though film is rewound automatically when it gets to the end of the roll. Therefore, if you need to rewind a roll continuously take pictures until the entire roll is exposed, then the camera will rewind on its own. The camera dial will be set back to $\mathrm{S}$ when rewound.

7. Load the film. Both cameras load the same way. Open the back and place the film in, drawing the leader in the direction indicated. Close the back. The camera should automatically forward the film. If it has loaded properly, the Yashica display will show 1. If it hasn't, the Yashica camera will continue to show 0. Open and reload as necessary. If the Canon has been loaded properly, the dial display will move to the 0 mark (between $S$ and 1). The Canon will continue to display $S$ if not loaded properly. 
8. Check camera alignment - the camera should be looking over the receiver at the bait.

9. Make sure the camera is on before you depart.

10. Check the bait - there should be at least most of a whole piece of bait here - add bait as necessary. Stake them to the ground using a nearby twig.

11. Re-scent every other check. Use a cotton swab to dab scent on the cotton cloth in the trap or outside it. You need very little - this is powerful stuff! Place the swab near the trap.

12. If units are in S.UP mode (setup) they will automatically turn over to event counting after 4 minutes in this mode. The cameras are set to take photos only between dusk and dawn and will not activate at other times.

\section{PASSIVE INFRARED CAMERAS (TM 550)}

Passive Units: have two parts: the transmitter/receiver, a 4" x 5" box with a prismatic lens, attached to a camera by a long black cord.

1. Record the number of events. Note that a large number of new events $(>100)$ may mean that something such as grass or twigs is waving back and forth in front of the unit triggering false events. Remove any suspect vegetation in front of the unit.

2. Record the number of pictures taken. Note that the smaller Yashica Cameras (black) with LCD display show the frame number to be taken (i.e., subtract 1 to get the number of pictures taken); the larger Canons with dial display show the number of pictures actually taken.

3. Check the cord to make sure it is still intact; some rodents like to eat through these. Replace as necessary. The cord with three prongs connects to the front of the camera with the wire hanging down. The stereo jack plugs into the bottom of the receiver.

4. Make sure that the unit is in alignment. The prism window should be pointed toward the bait station. Alignment can be checked using the following method:

- turn the unit to the set up mode by pressing the [SETUP] button until S.uP is displayed.

- a blinking light will flash in the upper left hand corner of the unit when the monitor detects motion.

- stand near the bait and use this blinking light to assess the area that the monitor is covering.

- once the edges of the coverage are found you can determine the center, this is important because this is where the camera should be focused.

- placing the unit in setup mode will give you 4 minutes to depart the area before the unit begins recording information.

5. Check that the camera still has power; replace lithium battery as necessary.

6. Check the film in the camera. If 32 pictures or more of a 36 roll or 20 pictures of a 24 roll are exposed, then rewind (or take pictures until all are exposed) and replace with a fresh roll. Immediately write the park code, date, time, station, and location on the used roll of film. The rewind button on the smaller Yashica cameras (black) is on the bottom of the camera, use a pen or pencil to press the small grey button. The camera should show 0 when rewound. The Canon camera (white) does NOT have a rewind button, though film is rewound automatically when it gets to the end of the roll. Therefore, if you need to rewind a roll continuously take pictures until the entire roll is exposed; then the camera will rewind on its own. The camera dial will be set back to $\mathrm{S}$ after the film has been rewound. 
7. Load the film. Both cameras load the same way. Open the back and place the film in, drawing the leader in the direction indicated. Close the back. The camera should automatically forward the film. If it has loaded properly, the Yashica display will show 1. If it hasn't, the Yashica camera will continue to show 0. Open and reload as necessary. If the Canon has been loaded properly, the dial display will move to the 0 mark (between $S$ and 1). The Canon will continue to display $S$ if not loaded properly.

8. Check camera alignment - the camera should be looking over the receiver at the bait station toward the center of coverage -reposition as necessary.

9. Make sure the camera is on before you depart.

10. Check the bait - there should be at least most of a whole piece of bait here - add bait as necessary. Stake them to the ground using a nearby twig.

11. Re-scent every other check. Use a cotton swab to dab scent on the cotton cloth in the trap or outside of it. You need very little - this is powerful stuff! Place the swab near the trap.

12. If units are in S.UP mode (setup) they will automatically turn over to event counting after 4 minutes in this mode. The cameras are set to take photos only between dusk and dawn and will not activate at other times. 


\section{Appendix E. Identification of mammalian hair.}

\section{Introduction}

Mammalian hair consists of two types: guard hairs and underfur. Underfur is often short and very fine, while guard hairs are longer, wider, and often more pigmented. We encountered both hair types while sampling. Terminology for describing hair morphology was derived from Moore and others (1974). Terms used are summarized as follows:

BANDS AND BANDING- refer to the different colored sections of the hair shaft; often viewed at low magnification (10x).

CORTEX- the inner structural component of a hair that surrounds the central area, i.e., medulla; often the site of pigment granules; must be viewed at high magnification (100-400x).

CUTICLE- outer protective hair surface that appears as clear cells, or scales, arranged in one or more various configurations; most often viewed at high magnification (100-400x).

CUTICULAR SCALES- cuticle cells on the surface of the hair shaft; often examined using an impression that is viewed at high magnification (100-400x).

MEDULLA- the center of the internal area of most hairs, similar to the pith in a tree twig; appears as a series of distinct cells or as a formless mass; often fails to extend the full length of shaft or is sporadically interrupted, also may be entirely absent in some hairs; must be viewed at high magnification $(100-400 x)$.

PROXIMAL, MEDIAL, and DISTAL- refer to three regions of the hair shaft from the follicle to the tip, respectively.

SHAFT- entire length of hair from follicle to tip.

SHIELD- a widened section of the shaft, often located in the distal region.

STRICTURE- a site of obvious constriction along the shaft.

\section{Methods}

\section{Hair Sample Preparation and Examination}

We made every effort to remove hairs from identified mammal carcasses found throughout the Northeast and catalogued a small number of known hairs to provide a reference collection. We used this collection for comparison to the collected hair samples.

We removed hairs from glue strips using a xylene rinse. This was necessary to weaken the glue and allow hairs to be gently removed from tape so as to minimize changes in structural integrity. In some cases we left hairs attached to the original glue strip; in particular, those samples with greater than 30 individual hairs were left. We retained all original glue strips and placed them in a freezer. We extracted hairs, soaked and gently agitated them in xylene for a few minutes to help remove traces of glue, dirt, and oils. We then left the sample hairs to dry before placing them in plastic envelopes marked with the following information: station, location, date, time of collection, glue strip position on hair trap, collector, and voucher number.

Whenever possible, we selected entire hairs for judicious inspection. We first examined individual hairs and noted the following gross characteristics:

1. Color- including general coloration and position of banding, if any.

2. Shape- presence of shield (i.e., distinctly widened portion of hair), waves, and strictures.

3. Hair shaft length- measured in millimeters.

For detailed microscopic examination, we placed individual hairs in a drop of xylene on a glass slide and covered with a glass cover slip. We examined minute hair morphology with the aid of a compound microscope, most often using 100x and 400x magnification. We examined proximal, medial, and distal regions of each hair. We noted the following microscopic characteristics:

1. Shaft width - measured in microns $(\mu \mathrm{m})$ at the greatest width observed using an ocular micrometer.

2. Medullary configuration - medulla appearance in each region using the following expressions:

a. Absent - no medulla.

b. Fragmented - occurring intermittently; interrupted by cortical material. 
c. Uniserial ladder - a continuous single column of distinct cells.

d. Continuous or unbroken amorphous- an uninterrupted cylindrical mass appearing to be without structure and obvious, discrete cells.

e. Continuous or unbroken cellular - an uninterrupted cylinder of distinct yet irregularly shaped cells.

f. Continuous or unbroken with cortical intrusions - an uninterrupted medulla with regular or irregular occurrences of cortical material.

g. Continuous or unbroken lattice - an uninterrupted network of many small cells, as in a tile mosaic, that occurs in hairs with a thin, virtually absent cortex.

h. Vacuolated - possessing distinct cells that appear as large vacuoles; occurs in hairs bearing continuous or unbroken cellular medullary configurations.

3. Relative medulla width- width of medulla in relation to width of shaft in each region; often expressed in fractions, as in one-quarter, one-third, etc.

4. Region of highest pigment intensity- portion of hair shaft with the greatest concentration of pigment granules.

We determined arrangements of cuticle scales, or cuticular scale patterns from an impression made of the outside surface of the hair. We made impressions using a modification of the method described by Williamson (1951). We smeared microscope slides with a thin layer of PVC cement and then laid clean hairs on the freshly applied PVC cement. We removed hairs after 1-2 minutes and before the cement had completely cured. Impressions were often three-dimensional with the topmost side often torn away when the hair was lifted. This was due to the hair being completely immersed in cement. We then inverted the slide on the microscope in order to view the "bottom" intact impression. Most often, we viewed impressions right-side up.
We described cuticular scale patterns or each region using vocabulary as suggested in Moore and others (1974). We described scale shape as follows:

1. Mosaic - the appearance of small pieces laid sideby-side; these pieces could be relatively uniform in shape and size (regular) or very different (irregular).

2. Ovate - egg-shaped in outline.

3. Acuminate - gently tapering to a sharp point.

4. Dentate - tooth-shaped, usually with smooth margins.

5. Pectinate - tooth-shaped with sharply pointed margins.

6. Wave - undulating margins.

Scale edges, or margins, were described as follows:

1. Smooth- having an even surface with no projections.

2. Rippled- with rounded toothy margins.

3. Crenate- with pointy-toothed margins.

We used a coarse relative measurement to describe adjacent scale margins: close, intermediate, or distant.

We attempted to identify all hairs using physical characteristics (e.g., color, length, width, scale pattern). To do this we used hair identification keys (Mayer, 1952; Moore and others, 1974; Moore and Braun, 1983; Thompson and others, 1987; Wallis, 1993) and also compared hairs to our collection of reference samples. However, due to the great diversity in physical hair characteristics within the same individual, among individuals of the same species, or the similarity among species, this technique had limited value for the identification of hairs to species. Therefore, we used a method that characterized hairs to species using protein analysis procedures described elsewhere (see Hollemeyer and others (2002) for details). 


\section{Appendix F. Observation card (front and back) used in the Northeast Temperate Network mammal inventory.}

\begin{tabular}{|c|c|c|c|c|c|c|c|c|}
\hline \multicolumn{9}{|l|}{ WHEN/WHO } \\
\hline \multicolumn{3}{|c|}{ Date $(\mathrm{mm} / \mathrm{dd} / \mathrm{yyyy}):$} & \multicolumn{4}{|c|}{ Time (24 clock): } & \multicolumn{2}{|c|}{ Observer (last name, first): } \\
\hline \multicolumn{9}{|c|}{ SPECIES OBSERVED } \\
\hline \multicolumn{3}{|c|}{ Common name: } & \multicolumn{4}{|c|}{ Genus: } & \multicolumn{2}{|l|}{ species: } \\
\hline \multicolumn{9}{|c|}{ IDENTIFICATION CONFIDENCE } \\
\hline \multicolumn{2}{|c|}{$\begin{array}{l}\text { (1) Certain - } \\
\text { specimen or photo } \\
\text { available. } \\
\square\end{array}$} & \multicolumn{3}{|c|}{$\begin{array}{l}\text { (2) Good - close obs. } \\
\text { distance., excellent } \\
\text { observer ID skills. } \\
\square\end{array}$} & \multicolumn{3}{|c|}{$\begin{array}{l}\text { (3) Fair - moderate obs. } \\
\text { distance, good ID skills, or } \\
\text { close distance, fair ID skills. } \\
\square\end{array}$} & $\begin{array}{l}\text { (4) Poor- far obs. } \\
\text { distance, or short obs. } \\
\text { Time. }\end{array}$ \\
\hline \multicolumn{9}{|c|}{ ENCOUNTER TYPE } \\
\hline 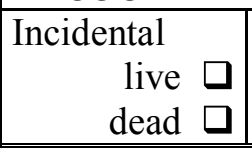 & \multicolumn{2}{|c|}{$\begin{array}{l}\text { Search due to } \square \\
\text { visitor report. }\end{array}$} & \multicolumn{3}{|c|}{\begin{tabular}{r|r|} 
Trapped & \\
live & $\square$ \\
dead & $\square$
\end{tabular}} & \multicolumn{2}{|c|}{ Survey (type): $\square$} & Other (describe): $\square$ \\
\hline \multicolumn{9}{|c|}{ EVIDENCE FOR IDENTIFICATION } \\
\hline \multicolumn{4}{|c|}{ 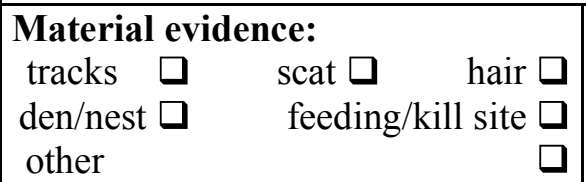 } & $\begin{array}{l}\text { Specime } \\
\text { vouche } \\
\text { other } \\
\text { ref. \#: }\end{array}$ & a av: & $\begin{array}{l}\text { ailable: } \\
\text { scat } \square \\
\end{array}$ & $\begin{array}{r}\text { hair } \\
\square \\
\end{array}$ & $\begin{array}{l}\text { Photo evidence: } \\
\text { digital } \square \quad 35 \mathrm{~mm} \square \\
\text { ref. \#: } \\
\text { file: }\end{array}$ \\
\hline
\end{tabular}

\section{LOCALITY INFORMATION}

\begin{tabular}{|l|l|l|}
\hline Town (county): & Park code: & Admin. unit:
\end{tabular}

Detailed location description (draw map below if necessary):

Habitat description:

\begin{tabular}{|ll|l}
\hline GPS coordinates: $\quad$ Lat.: & Long.: & Elevation (units):
\end{tabular}

NOTES/MAP: 


\section{Appendix G. Field data sheets distributed to park staff.}

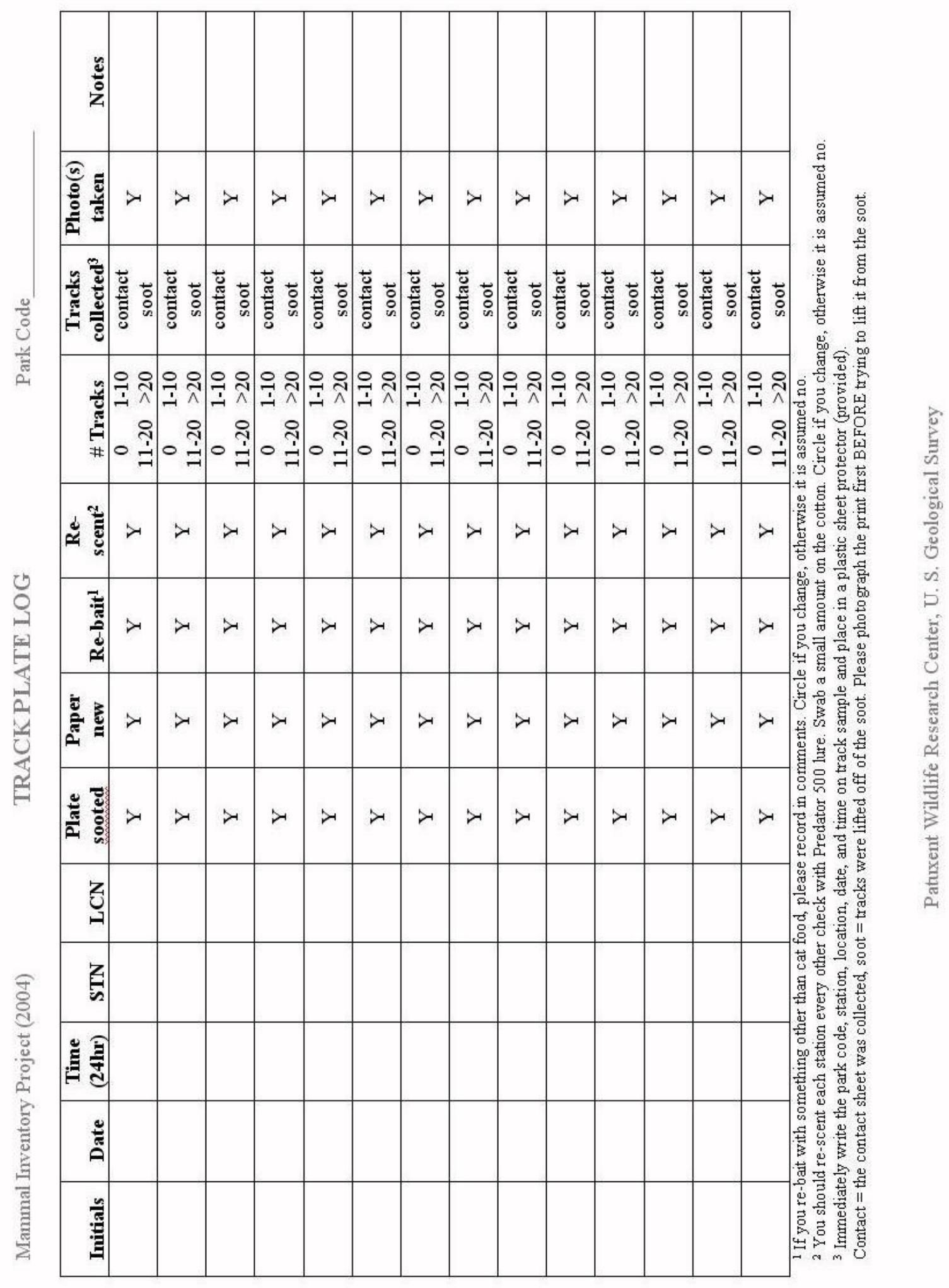




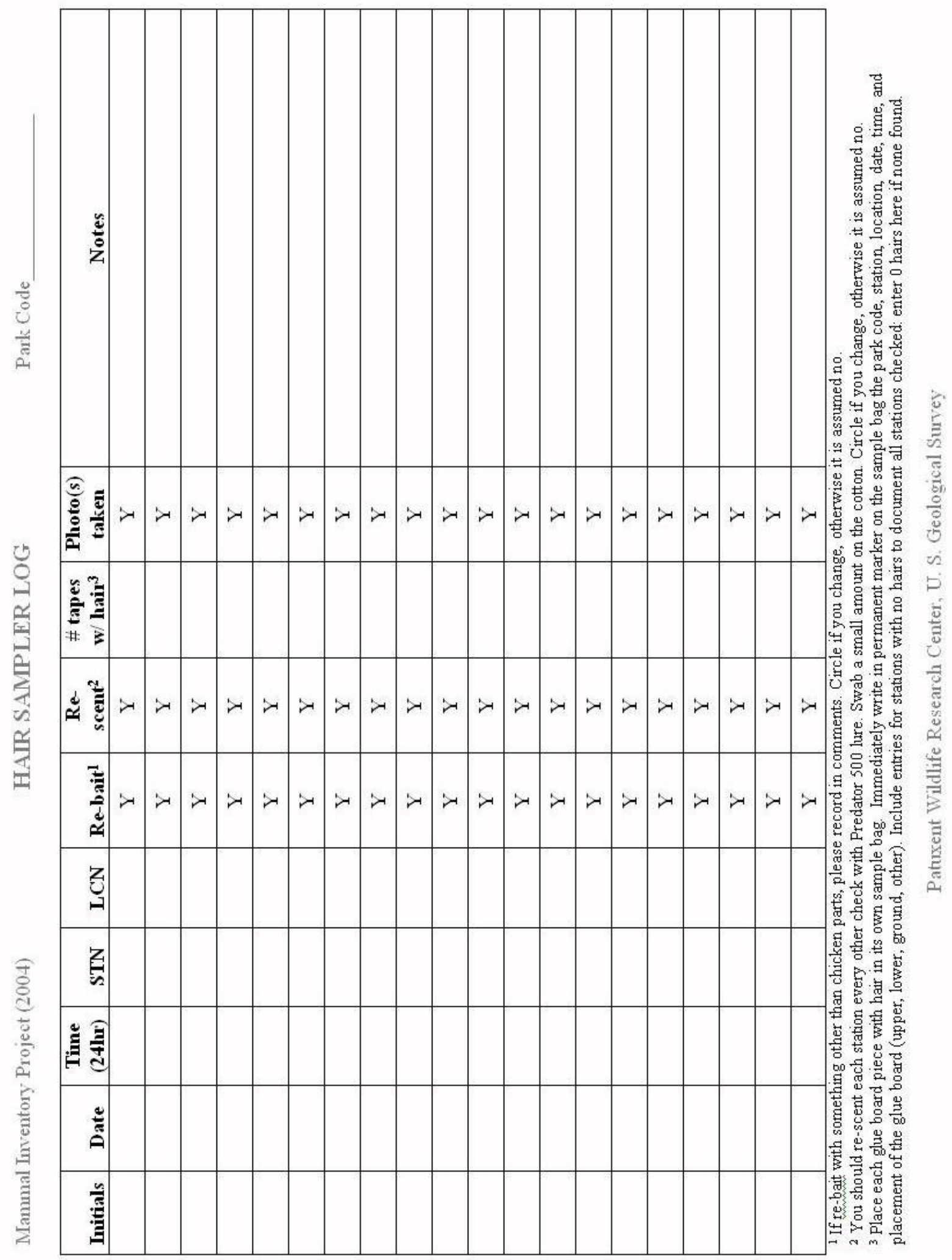




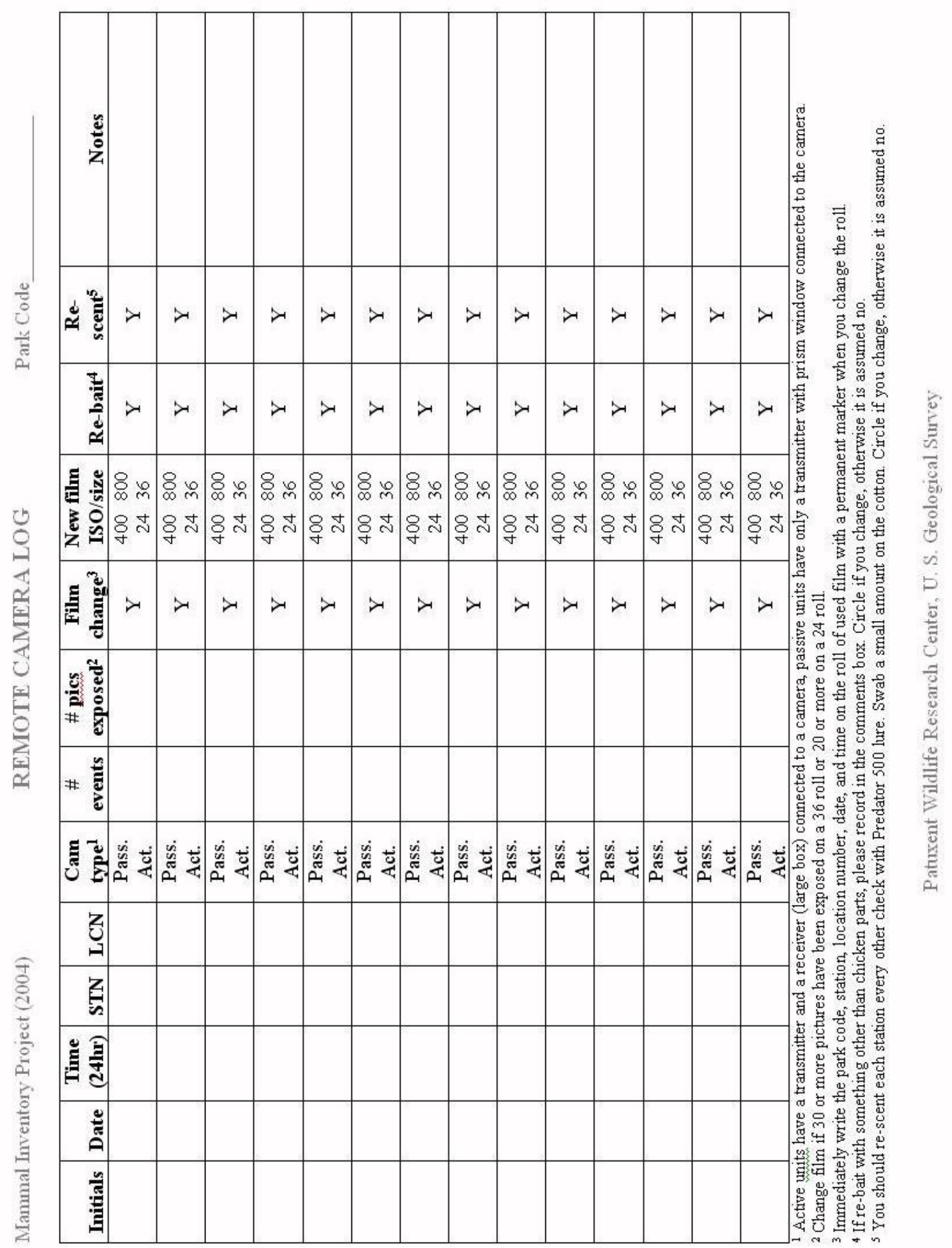




\section{Appendix H. Identified hairs collected during the Northeast Temperate Network and Sagamore Hill National Historic Site mammal inventory based on physical characteristics and matrix-assisted laser desorption/ionization time-of- flight mass spectrometry (MALDI-TOF) analysis.}

\begin{tabular}{|c|c|c|c|c|c|}
\hline \multirow{2}{*}{$\begin{array}{l}\text { Park } \\
\text { code }\end{array}$} & \multirow{2}{*}{$\begin{array}{l}\text { Station } \\
\text { number }\end{array}$} & \multirow{2}{*}{ Sample type } & \multicolumn{2}{|c|}{ Species identified } & \multirow{2}{*}{$\begin{array}{c}\text { Number } \\
\text { of } \\
\text { samples }\end{array}$} \\
\hline & & & Physical identification & MALDI-TOF identification & \\
\hline \multirow[t]{4}{*}{ ACAD } & 5 & hair trap & Long-tailed Weasel or Ermine & Ermine & 1 \\
\hline & & & & No samples run & 1 \\
\hline & 21 & hair trap & Red Squirrel & Gray Squirrel & 1 \\
\hline & & & & No samples run & 5 \\
\hline \multirow[t]{36}{*}{ MABI } & 2 & hair trap & Fisher & Ermine & 1 \\
\hline & & & & Ermine/Fisher & 1 \\
\hline & & & & Gray Fox & 1 \\
\hline & & & & Red Fox/Coyote & 1 \\
\hline & & & & Striped Skunk/Virginia Opossum & 1 \\
\hline & & & & Unknown & 1 \\
\hline & & & & Virginia Opossum & 1 \\
\hline & & & & No samples run & 7 \\
\hline & 4 & hair trap & Fisher & Ermine & 2 \\
\hline & & & & Red Fox/Coyote & 1 \\
\hline & & & & Striped Skunk & 1 \\
\hline & & & & Striped Skunk/Virginia Opossum & 1 \\
\hline & & & & No samples run & 4 \\
\hline & 5 & trap & Gray Squirrel & Red Squirrel & 1 \\
\hline & 6 & hair trap & Fisher & Virginia Opossum/Red Squirrel & 1 \\
\hline & & & & No samples run & 1 \\
\hline & 10 & hair trap & Fisher & Ermine & 2 \\
\hline & & & & Red Fox/Gray Fox & 1 \\
\hline & & & & No samples run & 2 \\
\hline & & & Squirrel spp. & Ermine & 1 \\
\hline & & & & Unknown & 1 \\
\hline & 12 & hair trap & Fisher & Gray Fox & 1 \\
\hline & & & Gray Squirrel & Red Squirrel & 1 \\
\hline & & & Squirrel spp. & Gray Squirrel & 1 \\
\hline & & & & Red Squirrel & 1 \\
\hline & & & & No samples run & 5 \\
\hline & 35 & hair trap & Fisher & Ermine & 1 \\
\hline & & & & Striped Skunk & 1 \\
\hline & & & & No samples run & 2 \\
\hline & 38 & hair trap & Fisher & Virginia Opossum & 1 \\
\hline & 46 & hair trap & Fisher & Ermine & 1 \\
\hline & & & & Raccoon & 1 \\
\hline & & & & Red Fox/Gray Squirrel & 1 \\
\hline & & & & No samples run & 3 \\
\hline & & & Raccoon & Raccoon & 1 \\
\hline & & & & Virginia Opossum/Raccoon & 1 \\
\hline
\end{tabular}




\begin{tabular}{|c|c|c|c|c|c|}
\hline \multirow{2}{*}{$\begin{array}{l}\text { Park } \\
\text { code }\end{array}$} & \multirow{2}{*}{$\begin{array}{l}\text { Station } \\
\text { number }\end{array}$} & \multirow{2}{*}{ Sample type } & \multicolumn{2}{|c|}{ Species identified } & \multirow{2}{*}{$\begin{array}{c}\text { Number } \\
\text { of } \\
\text { samples }\end{array}$} \\
\hline & & & \multirow[t]{2}{*}{ Physical identification } & MALDI-TOF identification & \\
\hline & & & & Virginia Opossum/Raccoon & 1 \\
\hline & \multirow{2}{*}{54} & & & Ermine/Raccoon & 1 \\
\hline & & & & Raccoon & 1 \\
\hline & \multirow[t]{4}{*}{59} & hair trap & Fisher & Ermine & 3 \\
\hline & & & & Ermine/Red Fox & 1 \\
\hline & & & & Virginia Opossum & 2 \\
\hline & & & & No samples run & 2 \\
\hline & \multirow{2}{*}{70} & & & Unknown & 1 \\
\hline & & & & No samples run & 1 \\
\hline & \multirow[t]{7}{*}{74} & hair trap & Fisher & Ermine & 2 \\
\hline & & & & Striped Skunk/Gray Fox & 1 \\
\hline & & & & Striped Skunk/Red Fox & 1 \\
\hline & & & & No samples run & 5 \\
\hline & & & Mustelid & Virginia Opossum/Fisher & 1 \\
\hline & & & & No samples run & 3 \\
\hline & & & Unknown & Ermine & 2 \\
\hline \multirow{19}{*}{ MIMA } & \multirow{3}{*}{13} & \multirow{3}{*}{ hair trap } & Raccoon & Fisher & 1 \\
\hline & & & & Virginia Opossum & 1 \\
\hline & & & Unknown & Unknown & 1 \\
\hline & \multirow[t]{2}{*}{30} & hair trap & Raccoon & Coyote & 1 \\
\hline & & & Squirrel spp. & Coyote/Virginia Opossum & 1 \\
\hline & \multirow[t]{7}{*}{33} & hair trap & Human & Ermine & 1 \\
\hline & & & Striped Skunk & Ermine & 1 \\
\hline & & & & Gray Fox/Virginia Opossum & 1 \\
\hline & & & & Striped Skunk & 1 \\
\hline & & & & Virginia Opossum & 1 \\
\hline & & & & No samples run & 1 \\
\hline & & & Unknown & Raccoon & 2 \\
\hline & \multirow[t]{2}{*}{37} & hair trap & Rodent spp. & No samples run & 1 \\
\hline & & & Unknown & Ermine/Coyote & 1 \\
\hline & 49 & trap & Rodent spp. & No samples run & 1 \\
\hline & \multirow[t]{3}{*}{51} & hair trap & Long-tailed Weasel or Ermine & Virginia Opossum & 1 \\
\hline & & & & No samples run & 1 \\
\hline & & & Raccoon & Virginia Opossum & 1 \\
\hline & 55 & hair trap & Virginia Opossum & Virginia Opossum & 1 \\
\hline
\end{tabular}




\begin{tabular}{|c|c|c|c|c|c|}
\hline \multirow{2}{*}{$\begin{array}{l}\text { Park } \\
\text { code }\end{array}$} & \multirow{2}{*}{$\begin{array}{l}\text { Station } \\
\text { number }\end{array}$} & \multirow[b]{2}{*}{ Sample type } & \multicolumn{2}{|c|}{ Species identified } & \multirow{2}{*}{$\begin{array}{c}\text { Number } \\
\text { of } \\
\text { samples }\end{array}$} \\
\hline & & & \multirow{2}{*}{$\begin{array}{l}\text { Physical identification } \\
\text { Fisher or Raccoon }\end{array}$} & MALDI-TOF identification & \\
\hline & 66 & hair trap & & Coyote & 1 \\
\hline & \multirow[t]{2}{*}{70} & \multirow[t]{2}{*}{ hair trap } & Human & Unknown & 1 \\
\hline & & & Virginia Opossum & Virginia Opossum & 2 \\
\hline & 78 & hair trap & & No samples run & 2 \\
\hline & 82 & hair trap & Human & Unknown & 1 \\
\hline \multirow[t]{30}{*}{ MORR } & \multirow[t]{9}{*}{5} & \multirow[t]{9}{*}{ hair trap } & \multirow[t]{2}{*}{ Raccoon } & Raccoon & 2 \\
\hline & & & & Striped Skunk & 1 \\
\hline & & & \multirow{3}{*}{ Unknown } & Raccoon/Ermine & 1 \\
\hline & & & & Raccoon/Virginia Opossum & 1 \\
\hline & & & & No samples run & 1 \\
\hline & & & \multirow[t]{4}{*}{ Virginia Opossum } & Raccoon/Fisher & 1 \\
\hline & & & & Striped Skunk & 1 \\
\hline & & & & Virginia Opossum & 5 \\
\hline & & & & No samples run & 7 \\
\hline & \multirow[t]{2}{*}{17} & \multirow[t]{2}{*}{ hair trap } & Domestic Cat & Raccoon & 1 \\
\hline & & & Striped Skunk & Ermine/Raccoon & 1 \\
\hline & \multirow[t]{4}{*}{19} & hair trap & Raccoon & Ermine/Raccoon & 1 \\
\hline & & & Unknown & No samples run & 1 \\
\hline & & & Virginia Opossum & Ermine/Raccoon & 1 \\
\hline & & & & Striped Skunk/Raccoon & 1 \\
\hline & 31 & hair trap & Virginia Opossum & Long-tailed Weasel/Red Fox & 1 \\
\hline & & & & Raccoon & 1 \\
\hline & 35 & trap & Deer or White-footed Mouse & No samples run & 1 \\
\hline & 43 & hair trap & Raccoon & Ermine & 1 \\
\hline & & & & Raccoon & 1 \\
\hline & & & Unknown & No samples run & 1 \\
\hline & & & Virginia Opossum & Raccoon & 1 \\
\hline & 47 & hair trap & Raccoon & Ermine & 2 \\
\hline & & & & Fisher/Striped Skunk/Raccoon & 1 \\
\hline & & & & Raccoon & 1 \\
\hline & & & & Virginia Opossum & 1 \\
\hline & & & & No samples run & 5 \\
\hline & & & Virginia Opossum & Ermine & 1 \\
\hline & & & & Ermine/Virginia Opossum & 1 \\
\hline & & & & Raccoon & 1 \\
\hline
\end{tabular}




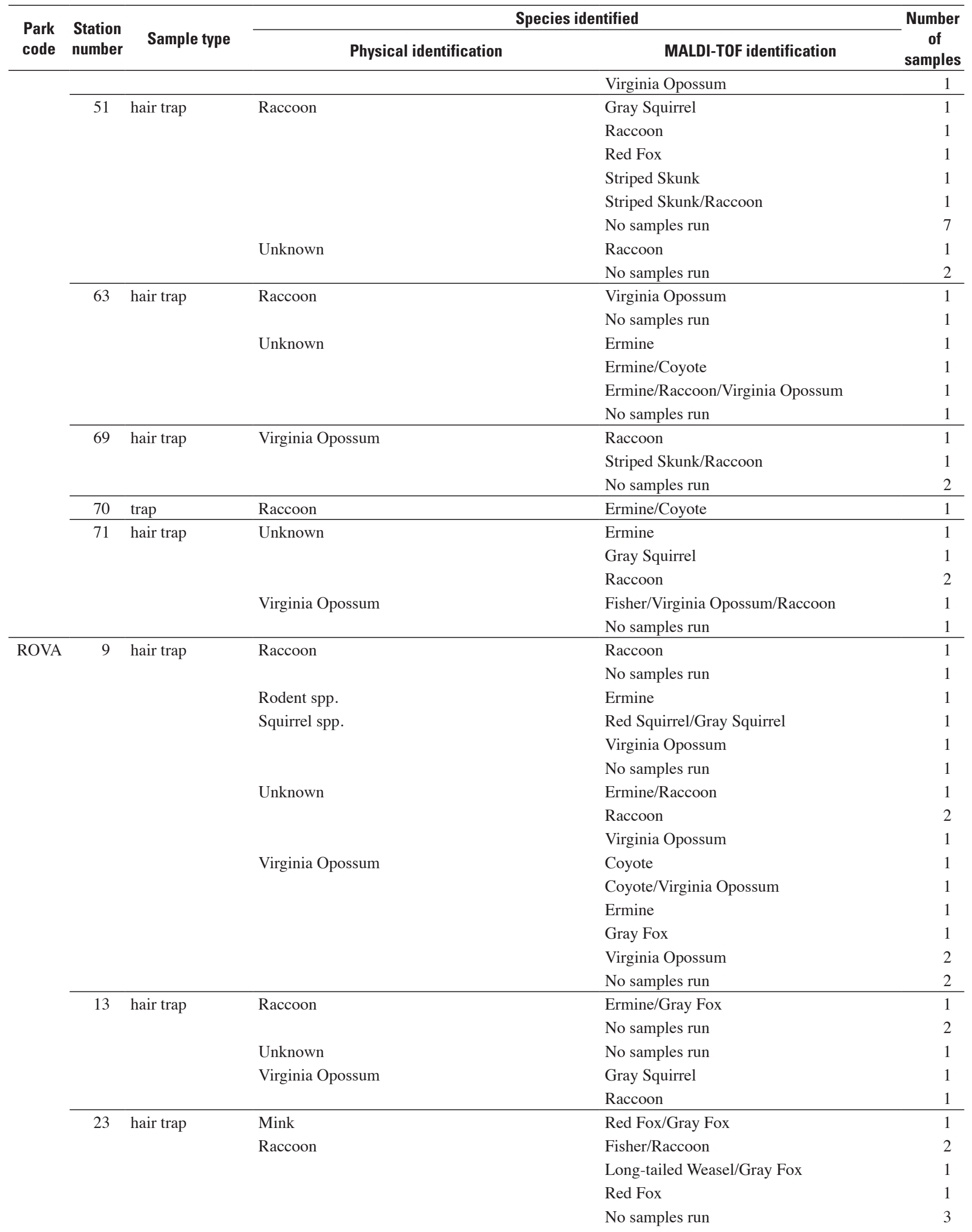




\begin{tabular}{|c|c|c|c|c|c|}
\hline \multirow{2}{*}{$\begin{array}{l}\text { Park } \\
\text { code }\end{array}$} & \multirow{2}{*}{$\begin{array}{l}\text { Station } \\
\text { number }\end{array}$} & \multirow{2}{*}{ Sample type } & \multicolumn{2}{|c|}{ Species identified } & \multirow{2}{*}{$\begin{array}{c}\text { Number } \\
\text { of } \\
\text { samples }\end{array}$} \\
\hline & & & \multirow[t]{2}{*}{ Physical identification } & MALDI-TOF identification & \\
\hline & & & & Virginia Opossum & 1 \\
\hline & & & \multirow[t]{6}{*}{ Virginia Opossum } & Coyote & 1 \\
\hline & & & & Ermine & 1 \\
\hline & & & & Raccoon & 1 \\
\hline & & & & Red Fox & 2 \\
\hline & & & & Virginia Opossum & 1 \\
\hline & & & & No samples run & 4 \\
\hline & \multirow{2}{*}{29} & & & No samples run & 1 \\
\hline & & & Squirrel spp. & Virginia Opossum & 1 \\
\hline & \multirow[t]{2}{*}{33} & den near hair trap & Woodchuck & Red Squirrel & 1 \\
\hline & & hair trap & Raccoon & Ermine & 1 \\
\hline & \multirow[t]{5}{*}{49} & hair trap & Raccoon & Red Fox/Ermine & 1 \\
\hline & & & & Virginia Opossum & 1 \\
\hline & & & & No samples run & 3 \\
\hline & & & Unknown & Red Squirrel/Red Fox & 1 \\
\hline & & & & Striped Skunk & 1 \\
\hline & \multirow{3}{*}{53} & & & Fisher/Raccoon & 1 \\
\hline & & & & No samples run & 3 \\
\hline & & & Virginia Opossum & Virginia Opossum & 1 \\
\hline & \multirow[t]{7}{*}{65} & hair trap & Squirrel spp. & Red Squirrel & 1 \\
\hline & & & Unknown & Ermine/Virginia Opossum & 1 \\
\hline & & & & Red Squirrel/Virginia Opossum & 1 \\
\hline & & & & No samples run & 1 \\
\hline & & & Virginia Opossum & Virginia Opossum & 2 \\
\hline & & & & No samples run & 5 \\
\hline & & trackplate & Raccoon & Red Squirrel & 1 \\
\hline & \multirow[t]{7}{*}{73} & hair trap & Raccoon & Raccoon & 1 \\
\hline & & & & Striped Skunk/Coyote & 1 \\
\hline & & & & No samples run & 6 \\
\hline & & & Red Fox & Red Fox & 1 \\
\hline & & & & Striped Skunk & 1 \\
\hline & & & & No samples run & 1 \\
\hline & & & Unknown & Ermine/Striped Skunk & 1 \\
\hline & 83 & hair trap & Squirrel spp. & Gray Squirrel & 1 \\
\hline & 86 & hair trap & Eastern Chipmunk or Red Squirrel & No samples run & 1 \\
\hline
\end{tabular}




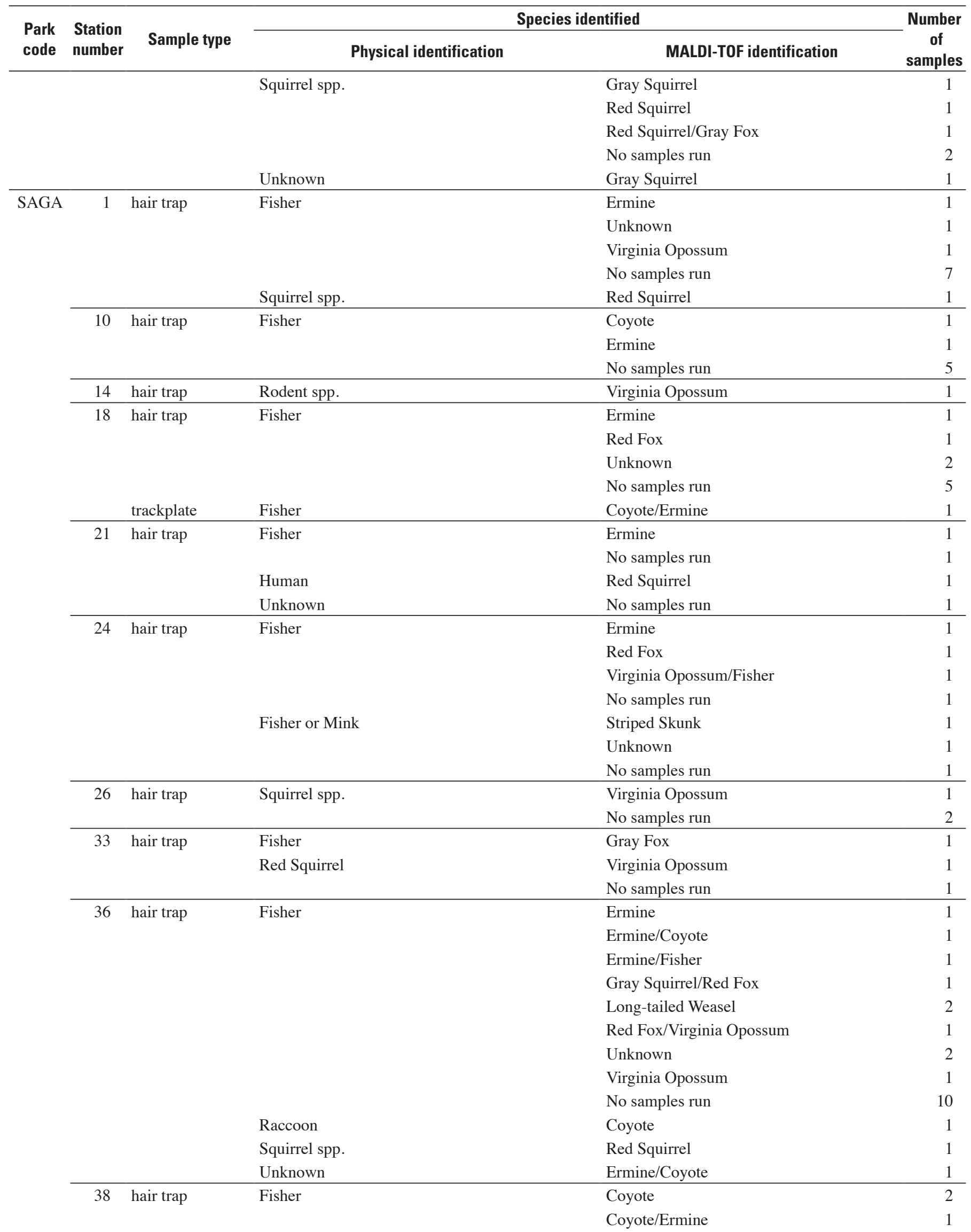




\begin{tabular}{|c|c|c|c|c|c|}
\hline \multirow{2}{*}{$\begin{array}{l}\text { Park } \\
\text { code }\end{array}$} & \multirow{2}{*}{$\begin{array}{l}\text { Station } \\
\text { number }\end{array}$} & \multirow{2}{*}{ Sample type } & \multicolumn{2}{|c|}{ Species identified } & \multirow{2}{*}{$\begin{array}{c}\text { Number } \\
\text { of } \\
\text { samples }\end{array}$} \\
\hline & & & Physical identification & MALDI-TOF identification & \\
\hline & & & & Gray Fox & 1 \\
\hline & & & & No samples run & 6 \\
\hline & & & Unknown & Ermine & 1 \\
\hline & & & & Gray Squirrel & 1 \\
\hline & & & & Red Fox & 1 \\
\hline & & & & No samples run & 6 \\
\hline \multirow[t]{18}{*}{ SAHI } & 9 & hair sampler & Domestic Cat & Virginia Opossum & 1 \\
\hline & & & & No samples run & 3 \\
\hline & 28 & hair trap & Raccoon & Ermine & 3 \\
\hline & & & & Gray Squirrel & 1 \\
\hline & & & & Red Fox & 2 \\
\hline & & & & Red Fox/Raccoon & 1 \\
\hline & & & & No samples run & 19 \\
\hline & 30 & hair trap & Domestic Cat & Red Squirrel & 1 \\
\hline & & & Virginia Opossum & Gray Squirrel/Red Squirrel & 1 \\
\hline & & & & Virginia Opossum & 2 \\
\hline & & & & Virginia Opossum/Raccoon/Unknown & 1 \\
\hline & & & & No samples run & 8 \\
\hline & 50 & hair trap & Human & No samples run & 1 \\
\hline & & & Raccoon & Raccoon & 1 \\
\hline & & & & Red Squirrel/Coyote & 1 \\
\hline & & & & Unknown & 1 \\
\hline & & & & Virginia Opossum & 3 \\
\hline & & & & No samples run & 13 \\
\hline \multirow[t]{5}{*}{ SAIR } & 5 & hair trap & Raccoon & No samples run & 1 \\
\hline & & & Unknown & No samples run & 3 \\
\hline & & & Virginia Opossum & No samples run & 8 \\
\hline & 23 & hair trap & Raccoon & No samples run & 6 \\
\hline & & & Unknown & No samples run & 1 \\
\hline \multirow[t]{6}{*}{ SARA } & 1 & hair trap & Long-tailed Weasel or Ermine & Ermine & 1 \\
\hline & & & & Gray Fox & 1 \\
\hline & & & & No samples run & 3 \\
\hline & 17 & hair trap & Eastern Chipmunk or Gray Squirrel & Gray Squirrel & 1 \\
\hline & & & & Virginia Opossum & 1 \\
\hline & & & & No samples run & 1 \\
\hline
\end{tabular}




\begin{tabular}{|c|c|c|c|c|c|}
\hline \multirow{2}{*}{$\begin{array}{l}\text { Park } \\
\text { code }\end{array}$} & \multirow{2}{*}{$\begin{array}{l}\text { Station } \\
\text { number }\end{array}$} & \multirow[b]{2}{*}{ Sample type } & \multicolumn{2}{|c|}{ Species identified } & \multirow{2}{*}{$\begin{array}{c}\text { Number } \\
\text { of } \\
\text { samples }\end{array}$} \\
\hline & & & Physical identification & MALDI-TOF identification & \\
\hline & & & Gray Squirrel & Red Fox & 1 \\
\hline & & & Unknown & Red Squirrel & 1 \\
\hline & & & & No samples run & 2 \\
\hline & & & & Virginia Opossum & 1 \\
\hline & & & & No samples run & 1 \\
\hline & 61 & trackplate & Unknown & No samples run & 1 \\
\hline & 77 & hair trap & Rodent spp. & Red Squirrel & 1 \\
\hline & & & Rodent spp. & No samples run & 1 \\
\hline & & hair trap & Cottontail spp. & Virginia Opossum & 1 \\
\hline & & & Gray Squirrel & No samples run & 1 \\
\hline & & & Long-tailed Weasel or Ermine & Ermine & 1 \\
\hline & & & Mink & No samples run & 3 \\
\hline & & & Squirrel spp. & Coyote/Gray Squirrel & 1 \\
\hline & & & Unknown & Red Fox & 1 \\
\hline & 97 & hair trap & Long-tailed Weasel or Ermine & No samples run & 2 \\
\hline & 101 & hair trap & Unknown & No samples run & 3 \\
\hline & & & & Striped Skunk/Ermine & 1 \\
\hline & & & & No samples run & 3 \\
\hline WEFA & 3 & hair trap & Unknown & No samples run & 1 \\
\hline & & & Virginia Opossum & Raccoon/Gray Fox & 1 \\
\hline & & & & Virginia Opossum & 1 \\
\hline & & & & No samples run & 1 \\
\hline & 13 & hair trap & Unknown & No samples run & 1 \\
\hline & & & Virginia Opossum & Virginia Opossum & 1 \\
\hline & & & & No samples run & 1 \\
\hline & 27 & hair trap & Virginia Opossum & Virginia Opossum & 2 \\
\hline & & & & No samples run & 2 \\
\hline & 35 & hair trap & Virginia Opossum & No samples run & 1 \\
\hline
\end{tabular}


For additional information, write to:

Director

U.S. Geological Survey

Patuxent Wildlife Research Center

12100 Beech Forest Road, STE 4039

Laurel, MD 20708-4039

or visit our Web site at: http://www.pwrc.usgs.gov/ 


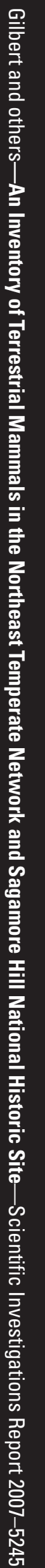

